ORP-56293

Revision 0

\title{
Final Report - Enhanced LAW Glass Formulation Testing, VSL-07R1130-1, Rev. 0, dated 10/05/07
}

Prepared for the U.S. Department of Energy

Assistant Secretary for Environmental Management

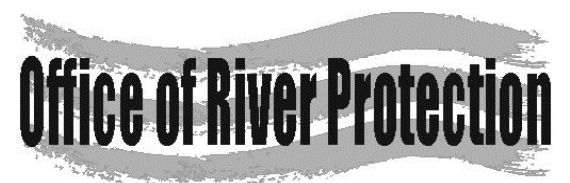

P.O. Box 450

Richland, Washington 99352 
ORP-56293

Revision 0

\section{Final Report - Enhanced LAW Glass Formulation Testing, VSL-07R1130-1, Rev. 0, dated 10/05/07}

A. A. Kruger

Department of Energy - Office of River Protection

I. L. Pegg

The Catholic University of America

K. S. Matlack

The Catholic University of America
I. Joseph

The Catholic University of America

I. S. Muller

The Catholic University of America

W. Gong

The Catholic University of America

Date Published

October 2007

Prepared for the U.S. Department of Energy

Assistant Secretary for Environmental Management

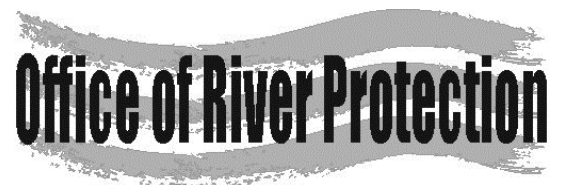

P.O. Box 450

Richland, Washington 99352

\section{APPROVED}

By Shauna Adams at 12:47 pm, Nov 13, 2013

Release Approval

Date 
ORP-56293

Revision 0

TRADEMARK DISCLAIMER

Reference herein to any specific commercial product, process, or service by tradename, trademark, manufacturer, or otherwise, does not necessarily constitute or imply its endorsement, recommendation, or favoring by the United States Government or any agency thereof or its contractors or subcontractors.

This report has been reproduced from the best available copy.

Printed in the United States of America 


\title{
Final Report
}

\section{Enhanced LAW Glass Formulation Testing}

\author{
prepared by
}

Keith S. Matlack, Innocent Joseph, Weiliang Gong, Isabelle S. Muller, and Ian L. Pegg

\author{
Vitreous State Laboratory \\ The Catholic University of America \\ Washington, DC 20064 \\ for \\ EnergySolutions \\ and \\ Department of Energy \\ Office of River Protection
}

August 31, 2007

Rev. 0, 10/5/07 
ORP-56293 Rev. 0

The Catholic University of America Vitreous State Laboratory
Enhanced LAW Glass, Formulation Testing Final Report, VSL-07R1130-I, Rev 0
Document Title:

Document Number and Revision:

Issue Date:
Enhanced LAW Glass Formulation Testing

VSL-07R1130-1, Rev, 0

$10 / 5 / 07$

Performing Organization: Vitreous State Laboratory, The Catholic University of America

Test Plan: $\quad$ Enhanced LAW Glass Formulation Testing, VSL-06 T1100-1, Rev. 0

. This report describes the results of testing specified by the above Test Plan. The work was performed in compliance with the quality assurance requirements specified in the Test Plan Results required by the Test Plan are reported. The test results and this report have been reviewed for correctness, technical adequacy, completeness, and accuracy.

I.L. Pegs:

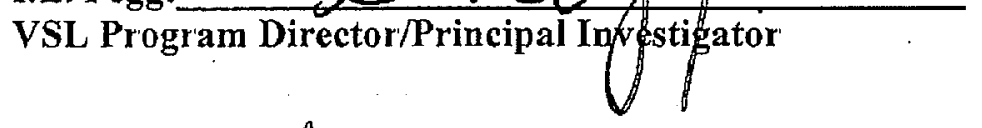

I. Joseph:

Duratek Sub-Contract Manager
Date: $10 / 5 / 07$

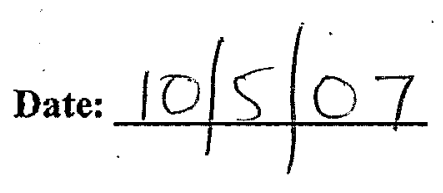

2 


\section{TABLE OF CONTENTS}

List of Tables.

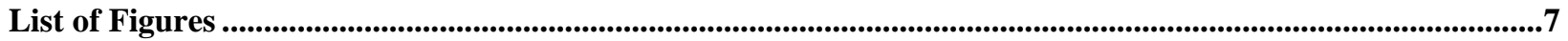

List of Abbreviations .........................................................................................................................................................8

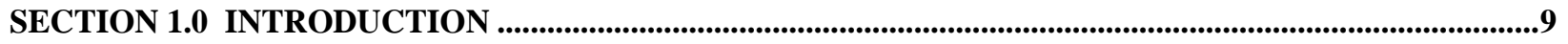

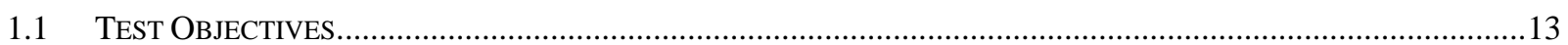

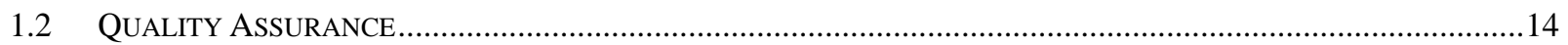

SECTION 2.0 WASTE SIMULANT, GLASS FORMULATIONS AND FEED ANALYSIS ..............................15

2.1 REGION A (ORPLA) WASTE SiMULANT AND GLASS FORMULATION..........................................................16

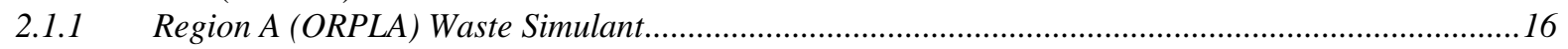

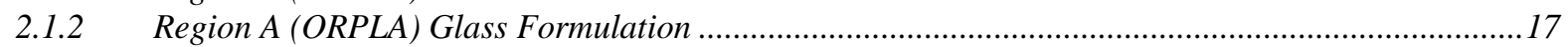

2.2 REGION B (ORPLB) WASTE SIMULANT AND GLASS FORMULATION .......................................................20

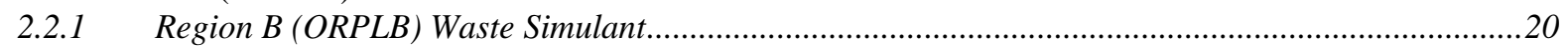

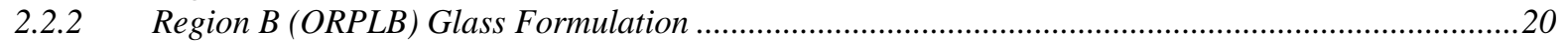

2.3 REGION C (ORPLC) WASTE SIMULANT AND GLASS FORMULATION ..........................................................22

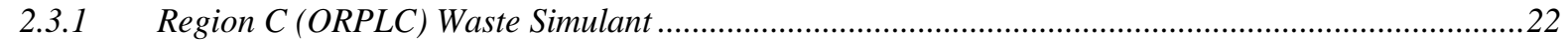

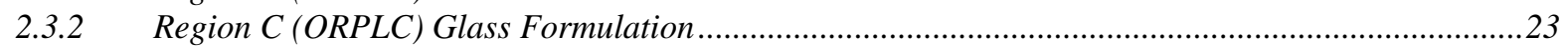

2.4 REGION D (ORPLD) WASTE SIMULANT AND GLASS FORMULATION..........................................................24

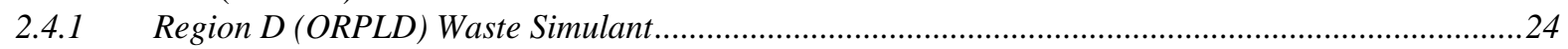

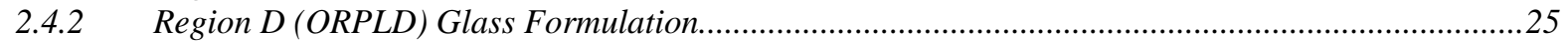

2.5 REGION E (ORPLE) WASTE SIMULANT AND GLASS FORMULATION ..........................................................26

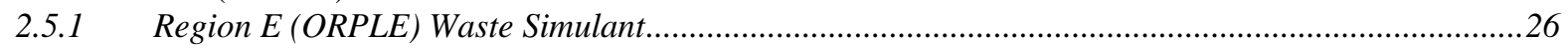

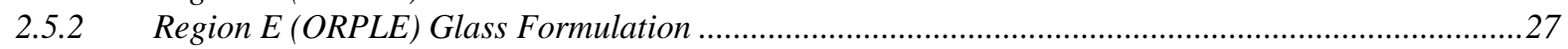

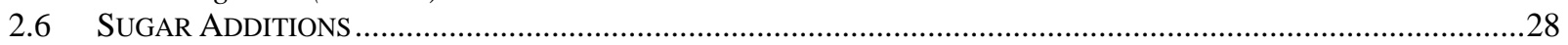

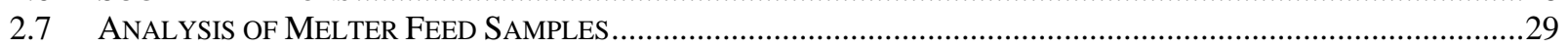

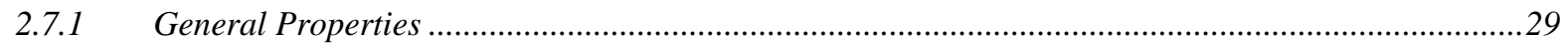

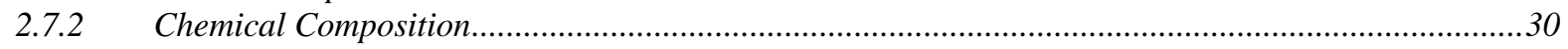

SECTION 3.0 DM10 TESTS ........................................................................................................................31

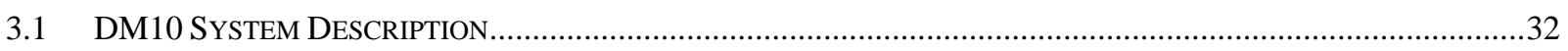

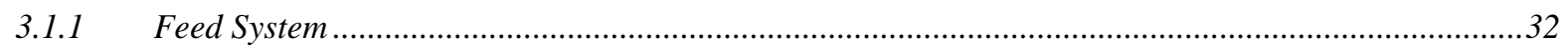

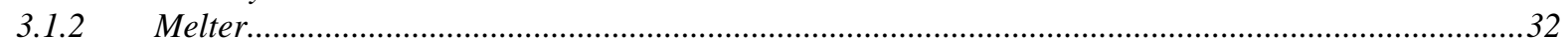

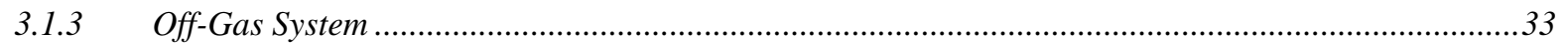

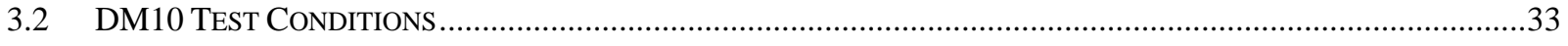

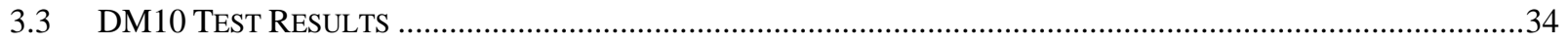

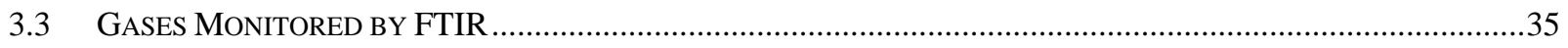

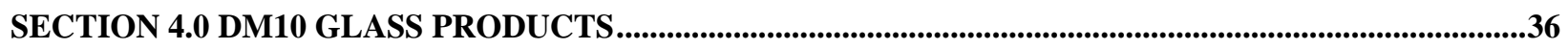

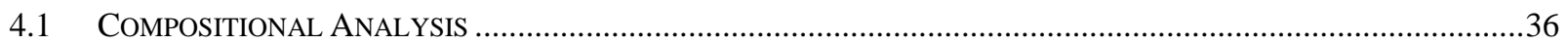

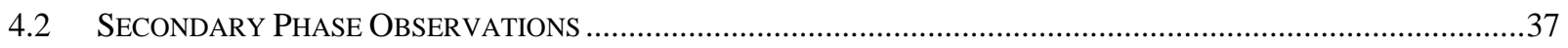

4.3 COMPARISON OF PCT AND VHT OF CRUCIBLE AND MELTER GLASSES ……................................................38

SECTION 5.0 SUMMARY AND CONCLUSIONS .......................................................................................40

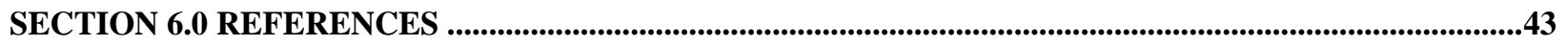




\section{List of Tables}

Table 1.1. Waste Compositions and Corresponding Target Concentrations in Glass.

Table 2.1. $\quad$ LAW Sub-Envelope A1 (AN-105) Waste Simulant Recipe at 8 Molar Sodium.

Table 2.2. $\quad$ Target and Analyzed Compositions (wt\%) of Seventeen ORPLA Crucible Glasses.

Table 2.3. Descriptions of Seventeen As-Melted and Heat Treated ORPLA $\begin{array}{lr}\text { Crucible Glasses. } & \text { T-6 }\end{array}$

Table 2.4. $\quad$ Measured Sulfate Solubility Limits in Seventeen ORPLA Glasses. $\quad$ T-7

Table 2.5. Results of 7-day PCT (at $90^{\circ} \mathrm{C}$ ) and VHT (at $200^{\circ} \mathrm{C}$ for 24 Days) $\begin{array}{lr}\text { for Seventeen ORPLA Crucible Glasses. } & \text { T-8 }\end{array}$

Table 2.6. Viscosities and Electrical Conductivities of Seventeen ORPLA Crucible Glasses.

Table 2.7. Results of K-3 Corrosion Testing for Seventeen ORPLA Crucible Glasses.

$\mathrm{T}-12$

Table 2.8. Summary of Test Results for Selected ORPLA Glass Formulation ORPLA15 and Comparison to ILAW Requirements.

$\mathrm{T}-13$

Table 2.9. Oxide Composition of AN-105 Simulant and ORPLA15 Glass Composition Used in Melter Tests (wt\%).

Table 2.10a. Glass Former Additives for 1 Liter of AN-105 Simulant (8 M Na) and Corresponding Melter Feed Properties.

Table 2.10b. $\mathrm{NaOH}$ and $\mathrm{Na}_{2} \mathrm{SO}_{4}$ Additions Required to Obtain $24 \mathrm{wt} \% \mathrm{Na}_{2} \mathrm{O}$ and Various $\mathrm{SO}_{3}$ Concentrations Ranging from 0.1 to $0.6 \mathrm{wt} \%$ in the ORPLA15 Glass.

Table 2.11. LAW Sub-Envelope C1 (AN-107) Waste Simulant Recipe at 8 Molar Sodium. $\quad$ T-16

Table 2.12. Target and Analyzed Compositions (wt\%) of Four ORPLB Crucible Glasses. T-17

Table 2.13. Descriptions of Four As-Melted and Heat Treated ORPLB Crucible Glasses. T-18

Table 2.14. Measured Sulfate Solubility Limits in Four ORPLB Crucible Glasses.

Table 2.15. Results of 7-day PCT (at $90^{\circ} \mathrm{C}$ ) and VHT (at $200^{\circ} \mathrm{C}$ for 24 Days) for Four ORPLB Crucible Glasses. $\quad$ T-19

Table 2.16. Viscosities and Electrical Conductivities of Four ORPLB Crucible Glasses. T-20

Table 2.17. Results of K-3 Corrosion Testing for Four ORPLB Crucible Glasses. $\quad$ T-20

Table 2.18. Summary of Test Results for Selected ORPLB Glass Formulation ORPLB4 and Comparison to ILAW Requirements.

Table 2.19. Oxide Composition of AN-107 Simulant and ORPLB4 Glass Composition Used in Melter Tests (wt\%).

Table 2.20a. Glass Former Additives for 1 Liter of AN-107 Simulant (8 M Na) and Corresponding Melter Feed Properties.

Table 2.20b. $\mathrm{NaOH}$ and $\mathrm{Na}_{2} \mathrm{SO}_{4}$ Additions Required to Obtain $24 \mathrm{wt} \% \mathrm{Na}_{2} \mathrm{O}$ and Various $\mathrm{SO}_{3}$ Concentrations Ranging from 0.6 to $1.0 \mathrm{wt} \%$ in the ORPLB4 Glass. $\quad \mathrm{T}-23$

Table 2.21. LAW Sub-Envelope A3 (AN-104) Waste Simulant Recipe at 8 Molar Sodium.

Table 2.22. Target and Analyzed Compositions (wt\%) of Five ORPLC Crucible Glasses. 
Table 2.23. Descriptions of Five As-Melted and Heat Treated ORPLC Crucible Glasses.

Table 2.24. Measured Sulfate Solubility Limits in Five ORPLC Crucible Glasses.

Table 2.25. Results of 7-day PCT (at $90^{\circ} \mathrm{C}$ ) and VHT (at $200^{\circ} \mathrm{C}$ for 24 Days) for Five ORPLC Crucible Glasses.

Table 2.26. Viscosities and Electrical Conductivities of Three ORPLC Crucible Glasses.

Table 2.27. Results of K-3 Corrosion Testing for Five ORPLC Crucible Glasses.

Table 2.28. Summary of Test Results for Selected ORPLC Glass Formulation ORPLC5 and Comparison to ILAW Requirements.

Table 2.29. Oxide Composition of AN-104 Simulant and ORPLC5 Glass Composition Used in Melter Tests (wt\%).

Table 2.30a. Glass Former Additives for 1 Liter of AN-104 Simulant (8 M Na) and Corresponding Melter Feed Properties.

Table 2.30b. $\mathrm{NaOH}$ and $\mathrm{Na}_{2} \mathrm{SO}_{4}$ Additions Required to Obtain $23.57 \mathrm{wt} \% \mathrm{Na}_{2} \mathrm{O}$ and Various $\mathrm{SO}_{3}$ Concentrations Ranging from 0.0 to $0.9 \mathrm{wt} \%$ in the ORPLC5 Glass.

Table 2.31. LAW Sub-Envelope C2 (AN-102) Simulant Recipe at 8 Molar Sodium.

Table 2.32. Target and Analyzed Compositions (wt\%) of Three ORPLD Crucible Glasses.

Table 2.33. Descriptions of Three As-Melted and Heat Treated ORPLD Crucible Glasses.

Table 2.34. Measured Sulfate Solubility Limits in Three ORPLD Crucible Glasses.

Table 2.35. Results of 7-day PCT (at $90^{\circ} \mathrm{C}$ ) and VHT (at $200^{\circ} \mathrm{C}$ for 24 Days) for Three ORPLD Crucible Glasses.

Table 2.36. Viscosity and Electrical Conductivity of ORPLD1 Crucible Glass.

Table 2.37. Results of K-3 Corrosion Testing for Three ORPLD Crucible Glasses.

Table 2.38. Summary of Test Results for Selected ORPLD Glass Formulation ORPLD1 and Comparison to ILAW Requirements.

Table 2.39. Oxide Composition of AN-102 Simulant and ORPLD1 Glass Composition Used in Melter Tests (wt\%).

Table 2.40a. Glass Former Additives for 1 Liter of AN-102 Simulant (8 M Na) and Corresponding Melter Feed Properties.

Table 2.40b. $\mathrm{NaOH}$ and $\mathrm{Na}_{2} \mathrm{SO}_{4}$ Additions Required to Obtain $21 \mathrm{wt} \% \mathrm{Na}_{2} \mathrm{O}$ and Various $\mathrm{SO}_{3}$ Concentrations Ranging from 0.0 to $1.3 \mathrm{wt} \%$ in the ORPLD1Glass.

Table 2.41. LAW Sub-Envelope B1 (AZ-101) Waste Simulant Recipe at 7.0 Molar Sodium.

Table 2.42. Target and Analyzed Compositions (wt\%) of Twelve ORPLE Crucible Glasses.

Table 2.43. Descriptions of Twelve As-Melted and Heat Treated ORPLE $\begin{array}{ll}\text { Crucible Glasses. } & \text { T-43 }\end{array}$

Table 2.44. Measured Sulfate Solubility Limits in Twelve ORPLE Crucible Glasses. T-44

Table 2.45. Results of 7-day PCT (at $90^{\circ} \mathrm{C}$ ) and VHT (at $200^{\circ} \mathrm{C}$ for 24 Days) for Twelve ORPLE Crucible Glasses.

Table 2.46. Viscosities and Electrical Conductivities of Twelve ORPLE Crucible Glasses.

Table 2.47. Results of K-3 Corrosion Testing for Ten ORPLE Crucible Glasses. 
Table 2.48. Summary of Test Results for Selected ORPLE Glass Formulation ORPLE12 and Comparison to ILAW Requirements.

Table 2.49. Oxide Composition of AZ-101 Simulant and ORPLE12 Glass Composition Used in Melter Tests (wt\%).

Table 2.50a. Glass Former Additives for 1 Liter of LAW AZ-101 Simulant (7 M Na) and Corresponding Melter Feed Properties.

Table 2.50b. $\mathrm{NaOH}$ and $\mathrm{Na}_{2} \mathrm{SO}_{4}$ Additions Required to Obtain $16 \mathrm{wt} \% \mathrm{Na}_{2} \mathrm{O}$ and Various $\mathrm{SO}_{3}$ Concentrations Ranging from 1.25 to $1.75 \mathrm{wt} \%$

in the ORPLE12 Glass. $\quad$ T-50

Table 2.51. Characteristics of Melter Feed Samples During DM10 ORP LAW Tests. T-51

Table 2.52. Compositions of Vitrified Melter Feed Samples During DM10 ORP LAW Tests (wt\%).

Table 3.1. $\quad$ Summary of Region E Test Conditions and Results. T-53

Table 3.2. $\quad$ Summary of Region A Test Conditions and Results. T-54

Table 3.3. $\quad$ Summary of Region B Test Conditions and Results. $\quad$ T-56

Table 3.4. Summary of Region C Test Conditions and Results. $\quad$ T-57

Table 3.5. Summary of Region D Test Conditions and Results. T-58

Table 4.1. $\quad$ Listing of DM10 Glasses Discharged, Masses, Target Sulfur

$\begin{array}{lr}\text { Contents and Analysis Performed. } & \text { T-59 }\end{array}$

Table 4.2. $\quad$ XRF Analyzed Compositions for DM10 Discharged Glass Samples (wt\%). T-65

Table 4.3. $\quad$ Compositions of Discharged Glass Samples During DM10

ORP LAW Tests with Maximum Sulfur Concentrations without

Secondary Phases (wt\%)

$\mathrm{T}-77$

Table 4.4. $\quad$ DCP Analyzed Compositions of Discharged Glass Samples During DM10 ORP LAW Tests with Maximum Sulfur Concentrations without Secondary Phases (wt\%).

Table 4.5. $\quad$ Listing of Dip Samples and Presence of Sulfate Layer During DM10 Melter Tests.

Table 4.6. $\quad$ Results of PCT Leaching Procedure for Crucible Glass and Corresponding Melter Glass Samples that Contain the Maximum Sulfur Content Without Formation of Secondary Phases During DM10 ORP LAW Tests.

Table 4.7. VHT Results (24 Day) for Crucible Glass and Corresponding Melter Glass Samples that Contain the Maximum Sulfur Content Without Formation of Secondary Phases During DM10 ORP LAW Tests.

Table 5.1. Maximum Sodium and Sulfur Oxide Concentrations Achieved in Crucible and Melter Tests (wt\% in Glass). 


\section{List of Figures}

Figure 2.1. Sulfate solubility determined by remelting with excess $\mathrm{SO}_{3}$ for forty one new ORP LAW crucible glasses.

Figure 2.3. Normalized PCT releases for forty one new ORP LAW crucible glasses.

Figure 2.4. K3 Corrosion results for thirty eight new ORP LAW crucible glasses and three old LAW formulations.

Figure 2.5. Results of $\mathrm{SO}_{2} / \mathrm{O}_{2}$ gas bubbling tests on the new ORP LAW glasses ORPLB4 and ORPLE12 and the previous ORP Envelope A glass LAWA161 at $1150^{\circ} \mathrm{C}$ showing the partial pressure of $\mathrm{SO}_{3}$ vs. the $\mathrm{SO}_{3}$ concentration in the glass melt.

Figure 3.1. Representative plot of glass pool temperatures during DM10 tests.

Figure 4.1. Secondary sulfur phases on discharge glass S10-G-109B from the end of Test 4D.

Figure 4.2. $\quad$ XRF analysis of sodium in DM10 product glasses.

Figure 4.15. Secondary sulfur phases on dip samples S10-D-110A, B, and C from the end of Test 4D.

Figure 4.16. Secondary sulfur phases on dip sample T10-D-24D from the end of Test 5D.

Figure 4.17. Comparison of VHT coupons for glass formulation ORPLA15. 


\section{List of Abbreviations}

$\begin{array}{ll}\text { AA } & \text { Atomic Absorption Spectroscopy } \\ \text { ANL-LRM } & \text { Argonne National Laboratory - Low-Activity Waste Reference Material } \\ \text { CCC } & \text { Canister Centerline Cooling } \\ \text { DCP-AES } & \text { Direct Current Plasma Atomic Emission Spectroscopy } \\ \text { DM } & \text { DuraMelter } \\ \text { DOE } & \text { Department of Energy } \\ \text { EDS } & \text { Energy Dispersive X-ray Spectroscopy } \\ \text { FTIR } & \text { Fourier Transform Infrared Spectroscopy } \\ \text { GFC } & \text { Glass Forming Chemical } \\ \text { HEPA } & \text { High-Efficiency Particulate Air Filter } \\ \text { HLW } & \text { High Level Waste } \\ \text { IC } & \text { Ion Chromatography } \\ \text { IHLW } & \text { Immobilized High Level Waste } \\ \text { ILAW } & \text { Immobilized Low Activity Waste } \\ \text { LAW } & \text { Low Activity Waste } \\ \text { M } & \text { Molarity } \\ \text { NQA } & \text { Nuclear Quality Assurance } \\ \text { ORP } & \text { Office of River Protection } \\ \text { PCT } & \text { Product Consistency Test } \\ \text { QA } & \text { Quality Assurance } \\ \text { QAPP } & \text { Quality Assurance Project Plan } \\ \text { QC } & \text { Quality Control } \\ \text { RPP } & \text { River Protection Project } \\ \text { SEM } & \text { Scanning Electron Microscope } \\ \text { TFCOUP } & \text { Tank Farm Contractor Operation and Utilization Plan } \\ \text { VHT } & \text { Vapor Hydration Test } \\ \text { VSL } & \text { Vitreous State Laboratory } \\ \text { WTP } & \text { Hanford Tank Waste Treatment and Immobilization Plant } \\ \text { XRF } & \text { X-Ray Fluorescence Spectroscopy } \\ & \end{array}$


The Catholic University of America

Vitreous State Laboratory
Enhanced LAW Glass Formulation Testing

Final Report, VSL-07R1130-1, Rev. 0

\section{SECTION 1.0 INTRODUCTION}

About 50 million gallons of high-level mixed waste is currently stored in underground tanks at The United States Department of Energy's (DOE's) Hanford site in the State of Washington. The Hanford Tank Waste Treatment and Immobilization Plant (WTP) will provide DOE's Office of River Protection (ORP) with a means of treating this waste by vitrification for subsequent disposal. The tank waste will be separated into low- and high-activity waste fractions, which will then be vitrified respectively into Immobilized Low Activity Waste (ILAW) and Immobilized High Level Waste (IHLW) products. The ILAW product will be disposed in an engineered facility on the Hanford site while the IHLW product will be directed to the national deep geological disposal facility for high-level nuclear waste. The ILAW and IHLW products must meet a variety of requirements with respect to protection of the environment before they can be accepted for disposal.

The Office of River Protection is currently examining options to optimize the Low Activity Waste (LAW) Facility and LAW glass waste form. One option under evaluation is to enhance the waste processing rate of the vitrification plant currently under construction. It is likely that the capacity of the LAW vitrification plant can be increased incrementally by implementation of a variety of low-risk, high-probability changes, either separately or in combination. These changes include:

- Operating at the higher processing rates demonstrated at the LAW pilot melter

- Increasing the glass pool surface area within the existing external melter envelope

- Increasing plant availability

- Increasing the glass waste loading

- Operating the melter at a slightly higher temperature

The Vitreous State Laboratory at The Catholic University of America (VSL) and EnergySolutions, Inc. have evaluated several of these potential incremental improvements for ORP in support of its evaluation of WTP LAW facility optimization [1]. Some of these incremental improvements have been tested at VSL including increasing the waste loading, increasing the processing temperature, and increasing the fraction of the sulfur in the feed that is partitioned to the off-gas stream (assuming that the present WTP recycle loop can be broken) [24]. These approaches successfully demonstrated increases in glass production rates and significant increases in sulfate incorporation and, therefore, waste loadings. This testing also demonstrated production rate increases and sulfur retention in the glass product at slightly higher than nominal glass processing temperatures. Subsequent tests demonstrated further enhancement of glass formulations for all of the LAW waste envelopes, increasing waste loading in the glass product and thereby reducing the amount of glass to be produced by the WTP for the same amount of waste processed $[5,6]$. In particular, test results showed sulfate loadings of up to 
The Catholic University of America Vitreous State Laboratory
Enhanced LAW Glass Formulation Testing Final Report, VSL-07R1130-1, Rev. 0

$1.2 \mathrm{wt} \% \mathrm{SO}_{3}$ in a LAW Envelope A glass containing 20 wt $\% \mathrm{Na}_{2} \mathrm{O}$ [2]; sulfur target concentrations of $1.6 \mathrm{wt} \%$ and $1.2 \mathrm{wt} \% \mathrm{SO}_{3}$, respectively, for glasses produced from $\mathrm{LAW}$ Envelope B and $\mathrm{C}$ wastes [5, 6]; and a sodium loading of $23 \mathrm{wt} \% \mathrm{Na}_{2} \mathrm{O}$ in a LAW Envelope A glass [6]. All of these formulations met all of the LAW product quality and processing requirements. Building on these very promising results, the testing described in this final report address a series of tests that expand this formulation approach to a wider range of waste types and assesses the extent to which further increases in waste loadings are possible. These tests entailed the development of glass formulations to maximize waste loading for five different LAW compositions (Regions A, B, C, D and E) followed by confirmatory small-scale melter testing of the selected formulations. The testing was designed to identify the limits of waste loading in glass formulations spanning the range of expected $\mathrm{Na}_{2} \mathrm{O}$ and $\mathrm{SO}_{3}$ concentrations in the LAW glasses in order to provide ORP with an assessment of bounds upon the waste loading improvements that might be possible for the LAW vitrification system. Once process variations and operating envelope requirements are imposed, the waste loadings for practically viable operating target compositions would be expected to have to fall beneath these bounds.

For a large number of Hanford LAW waste streams, sulfur is the main component that limits waste loading in glass. However, for some LAW Envelope A waste streams with low sulfate contents, the alkali concentration becomes the waste loading limiting factor. In general, waste loading is limited by sulfur for wastes with a high sulfur-to-sodium ratio, while those with a low sulfur-to-sodium ratio are limited by sodium (or more specifically, total alkali (sodium plus potassium)). Minimizing overall glass volume across the entire LAW inventory, which is clearly of economic benefit, therefore entails addressing both the sulfur limitation and the alkali limitation, depending on the waste type.

While processing melter feeds with very high sulfate concentrations, a molten sulfate salt phase forms in the cold-cap region during processing. This phase may exist as transient droplets or be sufficiently extensive to produce a separate salt phase that becomes mechanically disengaged from the rest of the cold cap. Once formed, the salt phase is slow to dissolve into the underlying glass melt; consequently, the salt phase typically forms before the underlying glass melt is saturated with sulfate [7-10]. If the feed rate is sufficiently low (which is clearly undesirable), the equilibrium sulfate saturation concentration in the glass can be approached more closely before a separate salt phase forms. However, in general, as the feed rate is increased, for the same sulfate concentration in the feed, the salt phase appears progressively earlier. Thus, in practice, the formation of a sulfate phase is governed by both thermodynamic and kinetic factors and, therefore, the effects of both must be considered in order to avoid the formation of such phases during operations. The presence of the corrosive, low-melting, electrically conductive salt phase is undesirable from the perspectives of melter operation, melter lifetime, safety, and product quality. Accordingly, the WTP plans to control the composition of the LAW melter feed such that formation of a separate salt phase is avoided. Clearly, the control bounds that are imposed will determine the achievable waste loading limits and, therefore, will determine the waste processing rate for a given glass production rate (i.e., melter capacity).

For waste with low sulfur-to-sodium ratio, waste loading is instead limited by the total alkali content in the glass. At high alkali contents, glass leach resistance (PCT and VHT) 
The Catholic University of America

Vitreous State Laboratory
Enhanced LAW Glass Formulation Testing Final Report, VSL-07R1130-1, Rev. 0

decreases and the refractory corrosion rate in the glass melt increases. In addition, the melt viscosity may become too low and the electrical conductivity may become too high. Typically, however, the product leach resistance and the refractory corrosion properties are the first to be compromised as the alkali content in the glass is increased. Accordingly, the present work addresses LAW streams spanning a range of sulfur-to-sodium ratios with the objective of determining the maximum achievable waste loadings across this range, from sodium-limited to sulfur-limited formulations. As noted above, the broader intent is to develop a basis for estimation of the potential maximum waste loadings and corresponding glass volumes for the entire LAW inventory.

Under a separate contract to support the WTP Project, the VSL is developing and testing glass formulations for RPP-WTP waste envelopes to provide data to meet the RPP-WTP contract requirements and to support system design activities [11-14]. That work is based upon small-scale batch melts ("crucible melts") using waste simulants. Selected formulations have also been tested in small-scale, continuously-fed, joule-heated melters (DM10 and DM100 systems) [9, 10, 15-24] and, ultimately, in the LAW Pilot Melter [25-36]. Such melter tests provide information on key process factors such as feed processing behavior, dynamic effects during processing, sulfate incorporation, processing rates, off-gas amounts and compositions, foaming control, etc., that cannot be reliably obtained from crucible melts. This sequential scale-up approach in the vitrification testing program ensures that maximum benefit is obtained from the more costly larger-scale melter tests and that the most effective use is made of those resources.

Under the WTP support effort, VSL and EnergySolutions have developed and identified glass compositions for processing the Phase I LAW tank waste streams for the WTP. These compositions have been tested for processing and product quality requirements at various scales ranging from crucible melts of about $400 \mathrm{~g}$ up to the LAW Pilot Melter at processing rates in excess of $6600 \mathrm{~kg} /$ day $\left(2000 \mathrm{~kg} / \mathrm{m}^{2} / \mathrm{day}\right)$. The testing included the nominal feed compositions and those with $\pm 15 \%$ variations in the waste simulants added to the melter feeds. The melter testing provided high confidence that the selected WTP compositions are unlikely to cause accumulation of a separate sulfate phase in the melter even at high feed processing rates. Feed processing characteristics and off-gas characteristics have been determined at various melter scales and data have been collected to support engineering and permitting requirements. Furthermore, statistically designed composition matrices were generated, and crucible melts of these glass compositions were prepared and characterized to qualify the glass composition region selected for WTP waste processing. The selected WTP compositions have also been tested to ensure their compatibility with melter materials of construction. The glass formulation development and melter testing work for the selected WTP compositions have reached a level of maturity where the compositions can be used for waste processing at the WTP with relatively high confidence.

The glass formulation and melter testing work described in the Test Plan for this work [37] and presented in this final report is aimed at identifying glass compositions that have the potential to accommodate higher waste loadings than does the present WTP baseline. This information will provide ORP with a basis for evaluation of the likely potential for future 
The Catholic University of America

Vitreous State Laboratory
Enhanced LAW Glass Formulation Testing Final Report, VSL-07R1130-1, Rev. 0

enhancements of the WTP over and above the present well-developed baseline. In this regard, this work is complementary to, and necessarily of a more exploratory nature than the work in support of the current WTP baseline. It should be noted, therefore, that to the extent that the present effort is successful, considerable further work would be required to bring the level of confidence in the new glass composition regions to a similar level of maturity to that of the current WTP baseline.

Glass compositions were developed targeting each of the five high sodium-sulfur waste loading regions specified in Table 1.1. Crucible melts were prepared and the samples were tested with respect to properties affecting processing (viscosity, electrical conductivity, crystallization, and refractory corrosion) and product quality (PCT and VHT). Based on the crucible melt results, a formulation was selected for DM10 melter testing for each of the glass regions. It was not known in advance the extent to which the target sulfur and sodium levels could be met, which was one of the principal reasons for performing this work. Thus, since the test outcomes were not known, the testing strategy allowed for appropriate compromises based on the test data that are collected. For each region, the crucible melt work identified suitable formulations for the target sodium content at the target sulfate content. If the target sodium content could not be achieved, the crucible work determined the highest sodium content that can be achieved for the target sulfate content. For example, it was determined that for Region D it was not possible to reach $\mathrm{Na}_{2} \mathrm{O}=25 \mathrm{wt} \%$ at $\mathrm{SO}_{3}=1.0 \mathrm{wt} \%$ while meeting all of the imposed product quality and processability constraints; instead, the highest $\mathrm{Na}_{2} \mathrm{O}$ content was $21 \mathrm{wt} \%$ at the target $\mathrm{SO}_{3}=1.0 \mathrm{wt} \%$ level, and therefore the maximum achievable sodium oxide loading used for the subsequent melter tests was $21 \mathrm{wt} \%$. The melter tests would then fix this sodium loading (and the corresponding glass formulation) and scan the $\mathrm{SO}_{3}$ loading from slightly below the target to the point at which a salt phase is formed. In this way, a point on the $\mathrm{Na}_{2} \mathrm{O}-\mathrm{SO}_{3}$ boundary was determined for each Region. A further constraint on the selection of each composition for melter testing was that the waste loading should not be lower than that indicated by the results from previous testing $[2,5,6]$.

Based on the crucible formulation logic described above, DM10 tests were performed on each of the five selected formulations. The melter tests described in this report utilized waste simulants prepared by Optima Chemicals according to VSL specifications that were blended with glass formers at VSL to produce the melter feed. Sufficient feed was prepared to produce over half a metric ton of glass. Reductant in the form of sugar was added to the feed at a stoichiometric ratio of 0.5 ( 1 mole sucrose per 16 moles NOx or 3 moles carbon per 4 moles NOx). For all but Region E (LAW AZ-101), the waste simulant was procured from Optima without sulfur and a corresponding portion of the sodium such that the sulfur content could be adjusted to desired concentrations by the addition of various combinations of $\mathrm{NaOH}$ and $\mathrm{Na}_{2} \mathrm{SO}_{4}$. The Region E simulant was procured with a target $\mathrm{SO}_{3}$ concentration of $1.25 \mathrm{wt} \%$ in the glass. These tests were performed at $1150^{\circ} \mathrm{C}$ and with a target glass production rate of $2,250 \mathrm{~kg} /\left(\mathrm{m}^{2}\right.$ day). Each test segment was nominally 14 hours duration, which corresponds to three melter turnovers for the DM10 melter system that was employed. In each test sequence, composed of about 3 to 6 test segments, the sulfate content was progressively increased to the point at which a sulfate salt phase developed, indicating the limit of sulfate incorporation for that particular formulation. Quantitative measurements of glass production rates, melter operating conditions 
The Catholic University of America Vitreous State Laboratory
Enhanced LAW Glass Formulation Testing Final Report, VSL-07R1130-1, Rev. 0

(temperatures, pressures, power, flows, etc.), and select gaseous emissions $\left(\mathrm{NOx}, \mathrm{SO}_{2}, \mathrm{CO}\right.$, and acid gases) were made for each test. Glass samples taken from the glass pool and the air-lift discharged glass were inspected throughout testing to determine the limit of feed $\mathrm{SO}_{3}$ concentration for operation of the melter without a separate sulfate phase.

The glass formulation development for this work followed a methodology developed by VSL/EnergySolutions during previous work. The methodology can be summarized as follows:

- Use existing glass formulation data and models to identify initial glass formulations for testing. The data used include ORP and WTP test data, data from other DOE programs, glass literature, geology, etc.

- Characterize the first set of glasses and use the information to refine the glass formulation for the next test set (active glass formulation design approach).

- Characterize glass samples for properties that are likely to be most challenging.

- For promising glasses, complete full characterization.

- Determine sulfur loading and processing characteristics through melter tests.

The glass formulation development work relied heavily on previous ORP work [2, 5, 6] and relevant WTP LAW glass formulation work [11-14]. Some of the earlier ORP glass compositions that were used to select starting glass compositions for the current tests include LAWA187 [6], LAWC100 [5], LAWA161 [2], and LAWB99 [6]. Existing property-composition models were used to guide glass formulation development. However, since the existing models are not expected to be reliable in the new composition regions that were explored in this work, glass science knowledge and experience, and information about the effect of various additives on glass structure and properties were used as additional tools to guide glass formulation development.

\subsection{Test Objectives}

The principal objective of this work was to extend the glass formulation methodology developed in the earlier work [2, 5, 6] for Envelope A, B and C waste compositions for development of compliant glass compositions targeting five high sodium-sulfur waste loading regions. This was accomplished through a combination of crucible-scale tests, and tests on the DM10 melter system. The DM10 was used for several previous tests on LAW compositions [2-4, 9 , 10] to determine the maximum feed sulfur concentrations that can be processed without forming secondary sulfate phases on the surface of the melt pool. This melter is the most efficient melter platform for screening glass compositions over a wide range of sulfate concentrations and therefore was selected for the present tests. The tests were conducted to provide information on melter processing characteristics and off-gas data, including sulfur incorporation and partitioning. As described above, the main objective was to identify the limits of waste loading in compliant glass formulations spanning the range of expected $\mathrm{Na}_{2} \mathrm{O}$ and $\mathrm{SO}_{3}$ concentrations in the LAW glasses. 
The five waste types selected and their respective target sodium and sulfur loadings are:

- Region A: LAW Sub-Envelope A1 (AN-105) with minimum concentrations of $\mathrm{Na}_{2} \mathrm{O}$ and $\mathrm{SO}_{3}$ of 25 and 0 weight percent, respectively.

- Region B: LAW Sub-Envelope C1 (AN-107) with minimum concentrations of $\mathrm{Na}_{2} \mathrm{O}$ and $\mathrm{SO}_{3}$ of 25 and 0.35 weight percent, respectively.

- Region C: LAW Sub-Envelope A3 (AN-104) with minimum concentrations of $\mathrm{Na}_{2} \mathrm{O}$ and $\mathrm{SO}_{3}$ of 25 and 0.65 weight percent, respectively.

- Region D: LAW Sub-Envelope C2 (AN-105) with minimum concentrations of $\mathrm{Na}_{2} \mathrm{O}$ and $\mathrm{SO}_{3}$ of 25 and 1.0 weight percent, respectively.

- Region E: LAW Sub-Envelope B1 (AZ-101) with minimum concentrations of $\mathrm{Na}_{2} \mathrm{O}$ and $\mathrm{SO}_{3}$ of 16 and 1.25 weight percent, respectively.

\subsection{Quality Assurance}

This work was conducted under a quality assurance program that is in place at the VSL that is based on Nuclear Quality Assurance (NQA)-1 (1989) and NQA-2a (1990) Part 2.7. This program is supplemented by a Quality Assurance Project Plan [38] for WTP work that is conducted at VSL. Test and procedure requirements by which the testing activities were planned and controlled are defined in the Test Plan [37]. The program is supported by VSL standard operating procedures that were used for this work [39]. The requirements of DOE/RW-0333P are not applicable to this work. 


\section{SECTION 2.0 WASTE SIMULANT, GLASS FORMULATIONS AND FEED ANALYSIS}

Glass formulation development and testing were conducted to identify compliant high waste loading glasses for Hanford LAW streams. The glass formulations covered a large portion of the expected range of $\mathrm{Na}_{2} \mathrm{O}$ and $\mathrm{SO}_{3}$ concentrations in LAW glasses. Based on the target $\mathrm{Na}_{2} \mathrm{O}$ and $\mathrm{SO}_{3}$ concentrations in the glasses, the glass formulation development was divided to focus on five LAW streams. The five waste types selected and their respective target sodium and sulfur loadings, as given in the Test Plan [37], are:

- Region A: LAW Sub-Envelope A1 (AN-105) with minimum concentrations of $\mathrm{Na}_{2} \mathrm{O}$ and $\mathrm{SO}_{3}$ of 25 and 0 weight percent, respectively.

- Region B: LAW Sub-Envelope C1 (AN-107) with minimum concentrations of $\mathrm{Na}_{2} \mathrm{O}$ and $\mathrm{SO}_{3}$ of 25 and 0.35 weight percent, respectively.

- Region C: LAW Sub-Envelope A3 (AN-104) with minimum concentrations of $\mathrm{Na}_{2} \mathrm{O}$ and $\mathrm{SO}_{3}$ of 25 and 0.65 weight percent, respectively.

- Region D: LAW Sub-Envelope C2 (AN-105) with minimum concentrations of $\mathrm{Na}_{2} \mathrm{O}$ and $\mathrm{SO}_{3}$ of 25 and 1.0 weight percent, respectively.

- Region E: LAW Sub-Envelope B1 (AZ-101) with minimum concentrations of $\mathrm{Na}_{2} \mathrm{O}$ and $\mathrm{SO}_{3}$ of 16 and 1.25 weight percent, respectively.

The waste simulant and glass formulations developed for each of these regions are described in Sections 2.1 through 2.5.

The intent of the testing was, while targeting the above values, to determine the highest achievable $\mathrm{Na}_{2} \mathrm{O}$ and $\mathrm{SO}_{3}$ loadings for each of the waste streams. Thus, as the formulation work progressed and data from testing became available, the target $\mathrm{Na}_{2} \mathrm{O}$ and $\mathrm{SO}_{3}$ concentrations in the glass formulations were revised. The revised target $\mathrm{SO}_{3}$ values that were used in glass formulation development are given below.

During the planning stages of this work, a total of 30 crucible melts were budgeted to develop glass formulations for all five regions. The plan was to first develop Region E glasses, then Region A, followed by Regions B, C and D with the objective of implementing the lessons learned from glass development for each Region into the next one. Sulfur and sodium loadings achieved for each Region were of value in formulating glasses for the next Region. For example, it was necessary to determine the maximum $\mathrm{Na}_{2} \mathrm{O}$ loading possible for Region A before proceeding to Region B glass testing. As testing progressed, it became clear that a much larger number of crucible melts would be required to meet the intent of the glass formulation development work. Ultimately, a total of 41 crucible melts were prepared and characterized. In 
The Catholic University of America

Vitreous State Laboratory
Enhanced LAW Glass Formulation Testing Final Report, VSL-07R1130-1, Rev. 0

addition, for all but the ORPLE glasses, VHT measurements were done in duplicate because of the high variability in the VHT results, particularly at high sodium contents. Following the test strategy stated in the Test Plan [37], more effort was focused on the measurement of glass properties that were judged to be most challenging for each set of glasses. Properties that were judged likely to be compliant with contract and processing requirements were either not measured, or measured only on select samples. The most economical and efficient way to make the best use of a limited number of crucible melts, to meet the test objective of developing high waste loading glasses for five different waste steams, is to prepare and characterize them in very small sets using data from the previous set to guide the design of the next set. In addition, it is most economical to limit initial characterization of the glasses to the properties that are likely to be the most challenging to meet; further characterization need then be done only on those samples that pass the initial tests. However, since VHT was the most challenging criterion to meet and VHT test duration is 24 days, time constraints did not always allow the above approach. In many cases, schedule constraints demanded that a larger number of crucible melts be made together and measurements of different glass properties be done in parallel.

\subsection{Region A (ORPLA) Waste Simulant and Glass Formulation}

Glass formulation development and testing for Region A (ORPLA) were based on the composition of LAW material from Hanford tank AN-105. Details of the waste simulant, and glass formulation development and testing are given below.

\subsubsection{Region A (ORPLA) Waste Simulant}

A LAW Envelope A waste simulant based on the composition data for tank AN-105, as given in a WTP Test Specification [40], was used as the basis for ORPLA glass formulations. The base waste composition incorporates TFCOUP [41] data, actual waste analysis data, and WTP flow sheet information. The sodium concentration in the simulant includes a $2.5 \%$ increase to account for sodium additions in pretreatment $[12,42]$. The nominal concentration, expressed in terms of the sodium molarity, was determined on the basis of melter feed rheology tests on similar formulations $[43,44]$. The results of those tests led to the selection of 8.0 molar sodium as the nominal simulant concentration for the LAW AN-105 waste. This is the same concentration that was used in previous WTP melter tests for LAW AN-105 waste [15, 22].

The nominal simulant formulation is given in Table 2.1. The LAW AN-105 simulant is a solution of predominantly sodium, aluminum, nitrate, and nitrite. Since the simulant was similar to those tested previously at the VSL, it was not necessary to prepare and perform screening tests on new laboratory samples. For the melter tests, Optima Chemicals, who supplied all of the LAW simulants for the previous DM100 and LAW Pilot Melter studies, prepared the waste simulant, which was shipped to VSL in 55-gallon drums. Glass forming chemicals, sugar as a reductant, and the requisite combinations of sodium hydroxide and sodium sulfate to adjust the sodium and sulfur contents of the feed for each test, were added at VSL. 
The Catholic University of America

Vitreous State Laboratory
Enhanced LAW Glass Formulation Testing Final Report, VSL-07R1130-1, Rev. 0

\subsubsection{Region A (ORPLA) Glass Formulation}

Glass formulation development for Region A (ORPLA) was based on the composition of the LAW AN-105 waste stream. The objective was to develop a glass formulation that can accommodate the highest concentration of $\mathrm{Na}_{2} \mathrm{O}$. High sulfate loading in the glass was not a primary objective for this region. The target $\mathrm{Na}_{2} \mathrm{O}$ and $\mathrm{SO}_{3}$ loadings in the ORPLA glass were $25 \mathrm{wt} \%$ and 0 to $0.3 \mathrm{wt} \%$, respectively. A total of seventeen crucible melts were prepared in an effort to identify a glass formulation that meets all processing and product quality requirements [45, 46]. Testing started with ORPLA1-ORPLA4 which showed that K-3 corrosion criteria are unlikely to be met without $\mathrm{Cr}_{2} \mathrm{O}_{3}$ addition. ORPLA5 showed that $\mathrm{ZnO}$ is helpful in reducing $\mathrm{K}-3$ corrosion. ORPLA6 to ORPLA10 showed that the K-3 corrosion criterion can be met with close to $6 \mathrm{wt} \% \mathrm{ZrO}_{2}$, that $\mathrm{SnO}_{2}$ improves VHT performance but reduces sulfur solubility, and that $\mathrm{CaO}$ improves sulfur solubility but increases K-3 corrosion. ORPLA12 to ORPLA14 showed that lower $\mathrm{Na}_{2} \mathrm{O}$ is needed to simultaneously meet VHT and K-3 corrosion requirements, but that the viscosity of the glasses needed to be reduced to meet processing limits. ORPLA15 to ORPLA17 were used to adjust the viscosity, so that a glass similar in properties to ORPLA7 or ORPLA12 could be obtained but with lower viscosity (and lower VHT than ORPLA7). Initially, glass formulations were tested at a $\mathrm{Na}_{2} \mathrm{O}$ concentration of $25 \mathrm{wt} \%$. Since none of these glasses met both processing and product quality requirements, additional glasses were prepared at lower $\mathrm{Na}_{2} \mathrm{O}$ concentrations of 23.5 and $24.0 \mathrm{wt} \%$. Since sulfate loading was not a primary objective, glass former additives such as $\mathrm{CaO}, \mathrm{Li}_{2} \mathrm{O}$, and $\mathrm{V}_{2} \mathrm{O}_{5}$ that facilitate higher sulfate loadings were either reduced in concentration or not added. For the very high $\mathrm{Na}_{2} \mathrm{O}$ glasses, the properties of most concern are Vapor Hydration Test (VHT) alteration rates and K-3 refractory corrosion. In order to reduce K-3 refractory corrosion, $\mathrm{Al}_{2} \mathrm{O}_{3}, \mathrm{SiO}_{2}$, and $\mathrm{ZrO}_{2}$ concentrations were maintained at high levels in all the glasses, and $\mathrm{Cr}_{2} \mathrm{O}_{3}$ was added at a concentration of about $0.5 \mathrm{wt} \%$ to most of the glasses. $\mathrm{ZrO}_{2}$ was found to be most beneficial in improving VHT performance, and was therefore maintained at high concentrations ( $>4 \mathrm{wt} \%)$ in all of the glasses. Based on the results of previous work [47], $\mathrm{SnO}_{2}$ was also added to improve VHT performance.

Target and analyzed compositions of the ORPLA glasses are given in Table 2.2. Glass compositions were determined by X-ray Fluorescence Spectroscopy (XRF) on powdered glass samples, except for $\mathrm{B}_{2} \mathrm{O}_{3}$, which was measured by Direct Current Plasma - Atomic Emission Spectroscopy (DCP-AES) after acid dissolution. As expected, measured concentrations of volatile components such as $\mathrm{Cl}$ and $\mathrm{SO}_{3}$ are lower than target. As is evident from the table, the target and analyzed compositions show good agreement. XRF measured $\mathrm{Cr}_{2} \mathrm{O}_{3}$ concentrations in glasses with target concentration of $\sim 0.5 \mathrm{wt} \%$ are, in general, about $25 \%$ above target. We believe that this is due to a small high bias in the XRF data in this range; no bias correction was applied to the XRF data presented in this report. DCP-AES analysis of the crucible glasses targeting $0.5 \mathrm{wt} \% \mathrm{Cr}_{2} \mathrm{O}_{3}$ gave values ranging from 0.47 to $0.53 \mathrm{wt} \%$, which is in agreement with the target concentration. Testing of all formulations started with glass preparation and optical microscopic evaluation of the as-melted sample. Glass samples were heat treated for 20 hours at $950^{\circ} \mathrm{C}$ and then evaluated for secondary phases. Observations of the as-melted and heat treated glasses are given in Table 2.3. All of the as-melted glasses appeared clear with some containing small amounts $(<0.1$ vol\%) of crystals. Some of the heat treated glasses showed spinel crystals. 
The Catholic University of America Vitreous State Laboratory
Enhanced LAW Glass Formulation Testing Final Report, VSL-07R1130-1, Rev. 0

Na-Zr-silicate crystals were present in some of the glasses that had high $\mathrm{ZrO}_{2}$ content. Sncontaining crystals also were detected in ORPLA15 glass, which had the highest $\mathrm{SnO}_{2}$ concentration.

The sulfate solubilities of the ORPLA glass compositions were assessed by batch saturation tests. This is a crucible-scale screening test that is used to obtain an indication of the extent of sulfur incorporation that will be obtained under actual melter operating conditions, which is, of course, the measure that is of practical importance. The results of these screening tests are then used to guide the range over which the melter tests are performed. The batch saturation tests were performed by remelting finely ground samples of the glasses with an excess of sulfate amounting to $4 \mathrm{wt} \% \mathrm{SO}_{3}$ if all of it were retained in the glass. The remelted glass samples are identified with an S4 at the end of the sample name. Results of sulfate batch saturation tests are given in Table 2.4 and Figure 2.1. The results identified as "after acid wash" are analyses of glass samples remelted with $4 \mathrm{wt} \% \mathrm{SO}_{3}$ after grinding and washing to remove any interstitial sulfate phases, to ensure that only the $\mathrm{SO}_{3}$ that is dissolved in the glass is measured. The sulfate retentions in the glasses ("after acid wash") varied from about 0.27 wt\% $\mathrm{SO}_{3}$ for ORPLA15 to $0.55 \mathrm{wt} \% \mathrm{SO}_{3}$ for ORPLA9. Since high sulfur loading was not an objective of the glass development work for Region A, sulfur solubility in these glasses was not measured by the $\mathrm{SO}_{2}$ bubbling method. The resources were instead used where most needed, such as for VHT and K-3 corrosion testing.

VHT and PCT results are summarized in Table 2.5 and illustrated in Figures 2.2 and 2.3. Since VHT results typically have fairly large relative standard deviation [48], the measurements were conducted on two samples each for all of the ORPLA glasses; one sample with the nominal $\mathrm{SO}_{3}$ concentration and the other from the remelt with $4 \mathrm{wt} \% \mathrm{SO}_{3}$. VHT results given in Table 2.5 and Figure 2.2 show that a number of ORPLA glasses exceeded the VHT alteration rate requirement of $50 \mathrm{~g} / \mathrm{m}^{2} /$ day. This was not unexpected because VHT requirement becomes more challenging as the alkali content of the glasses are increased and the intent was to examine bounding formulations. All four of the glasses with both VHT alteration rate measurements less than $50 \mathrm{~g} / \mathrm{m}^{2} /$ day contain $\mathrm{SnO}_{2}$ and high concentrations of $\mathrm{ZrO}_{2}$. PCT releases for the glasses given in Table 2.5 and Figure 2.3 show that all of the glasses met the ILAW product quality requirement of normalized mass loss of less than $2 \mathrm{~g} / \mathrm{m}^{2}$ for $\mathrm{B}, \mathrm{Na}$, and $\mathrm{Si}$. The viscosities and electrical conductivities of the glasses at select temperatures are given in Table 2.6. All of the electrical conductivity values are in the acceptable range for processing. However, viscosities of the glasses are generally high and some are outside of the acceptable range for melt processing [45]. Again, this is not unexpected because the glasses were designed to have viscosities towards the high limit for acceptability in order to reduce refractory corrosion. Glasses with viscosities both above and below the acceptance limit had to be prepared and characterized in order to identify glass compositions that are at the limit of acceptable viscosity for processing. Existing viscosity models are not useful for this purpose because the compositions explored in this work are outside of the applicable composition range of the models and, therefore, the model predictions are not reliable. Due to the high alkali content of the ORPLA glass formulations, K-3 refractory corrosion was a significant concern and, therefore, all of the glasses were tested for their K3 corrosion characteristics. K-3 refractory corrosion test results for the glasses are given in Table 2.7 and Figure 2.4, where they are compared to the results for some of the previously 
The Catholic University of America Vitreous State Laboratory
Enhanced LAW Glass Formulation Testing Final Report, VSL-07R1130-1, Rev. 0

tested ORP LAW glasses [2, 5, 6]. A number of the glasses had unacceptable K-3 corrosion characteristics, which could impact melter life. Acceptability of the corrosion characteristics of a glass composition is somewhat subjective because a glass composition that shows slightly higher K-3 corrosion, but allows higher waste loading, may be a more economic choice than one with lower K-3 corrosion and lower waste loading. However, for WTP LAW glass formulation development, a neck corrosion of 0.035 inches on 6-day K-3 coupon corrosion test at $1208^{\circ} \mathrm{C}$ has been used as an acceptance limit. A neck loss of about 0.035 inches in the corrosion test corresponds to less than about one inch of K-3 corrosion per year for the WTP melter; however, the precise relationship will depend on other factors, such as the production rate, operating temperature, etc. For the current LAW glass formulation development work for ORP, since higher waste loading compositions are being explored, a slightly higher neck corrosion value of 0.040 inches has been used as a guide for acceptable corrosion characteristics.

Of all seventeen ORPLA glass formulations tested, only one, ORPLA15, met all processing and product quality requirements and was, therefore, selected for melter testing. The measured properties of the glass ORPLA15 are compared to the ILAW performance requirements $[45,46]$ in Table 2.8. Density and glass transition temperature $\left(T_{g}\right)$ measurements, and canister centerline cooling (CCC) heat treatment were not conducted on ORPLA15 glass because the glass is expected to be acceptable with respect to these properties. Of all the LAW glasses tested to date for Hanford, none had density values over or near the contract limit of $3.7 \mathrm{~g} / \mathrm{cc}$ and therefore with high confidence ORPLA15 is expected to have a density of less than $3.7 \mathrm{~g} / \mathrm{cc}$. The only requirement for $\mathrm{T}_{\mathrm{g}}$ is that it be measured and reported. Since the sample heat treated at $950^{\circ} \mathrm{C}$ for 20 hours showed only $0.3 \mathrm{vol} \%$ of crystals, CCC treatment is not expected to cause extensive crystallization. Though cooling of the glass discharged from the DM10 melter occurs faster than in a WTP LAW canister, examination of cooled ORPLA15 glass samples from the DM10 melter corroborated this expectation in that very few crystals were present in the discharge glass samples.

The composition of the ORPLA15 glass used in melter tests is given in Table 2.9 along with the oxide contributions from the LAW AN-105 waste simulant and from the glass former additives. The simulant was procured with no $\mathrm{SO}_{3}$ and the sulfur concentration was increased in steps during the melter tests by adding the appropriate amounts of $\mathrm{Na}_{2} \mathrm{SO}_{4}$ and $\mathrm{NaOH}$ to the feed. The melter feed was procured at a $\mathrm{Na}_{2} \mathrm{O}$ concentration of $23.41 \mathrm{wt} \%$ in order to accommodate $\mathrm{Na}_{2} \mathrm{SO}_{4}$ and $\mathrm{NaOH}$ additions, without increasing the $\mathrm{Na}_{2} \mathrm{O}$ concentration above $24.0 \mathrm{wt} \%$. The types and amounts of glass former additives used to prepare the melter feed along with the target feed properties are given in Table 2.10a. The glass former additives are the same as those planned for use at the WTP, with the exception of chromium and tin, which would be new additives. The amounts of $\mathrm{Na}_{2} \mathrm{SO}_{4}$ and $\mathrm{NaOH}$ added to the feed to obtain $24 \mathrm{wt} \% \mathrm{Na}_{2} \mathrm{O}$ and 0.10 to $0.60 \mathrm{wt} \% \mathrm{SO}_{3}$ are given in Table $2.10 \mathrm{~b}$. 


\subsection{Region B (ORPLB) Waste Simulant and Glass Formulation}

Glass formulation development and testing for Region B (ORPLB) were based on the composition of LAW material from Hanford tank AN-107. Details of the waste simulant and glass formulation development and testing are given below.

\subsubsection{Region B (ORPLB) Waste Simulant}

A LAW Envelope C waste simulant based on the composition data for tank AN-107, as given in a WTP Test Specification [40], was used as the basis for ORPLB glass formulations. The base waste composition incorporates TFCOUP [41] data, actual waste analysis data, and WTP flow sheet information. The sodium concentration in the simulant includes a $17.65 \%$ increase to account for sodium additions in pretreatment $[12,42]$. The nominal concentration, expressed in terms of the sodium molarity, was estimated on the basis of melter feed rheology tests on similar formulations [43, 44]. The concentration of the simulant used in melter tests was 8.0 molar sodium. This is higher than that used in previous melter tests [20,22] because of the higher waste loading in the ORPLB glasses. As the waste loading increases, waste simulants at higher concentrations can be used to prepare melter feed because lesser amounts of glass forming chemicals need to be added.

The nominal simulant formulation is given in Table 2.11. The LAW AN-107 simulant is a solution of predominantly sodium, nitrate, nitrite, and sulfate. Preparation of the waste simulant and melter feed were done in a manner similar to that for ORPLA simulant, which is described in Section 2.1.1.

\subsubsection{Region B (ORPLB) Glass Formulation}

Glass formulation development for Region B (ORPLB) was based on the composition of the LAW AN-107 waste stream. For glass formulation purposes, the target $\mathrm{SO}_{3}$ loading in the ORPLB glass was 0.2 to $0.5 \mathrm{wt} \%$. Four crucible melts were prepared in an effort to identify a glass formulation that meets all processing and product quality requirements. Similar to the ORPLA glasses, the properties of most concern were VHT alteration rate and K-3 refractory corrosion. In order to reduce K-3 refractory corrosion, $\mathrm{Al}_{2} \mathrm{O}_{3}, \mathrm{SiO}_{2}$, and $\mathrm{ZrO}_{2}$ concentrations were maintained at high levels in all the glasses, and $\mathrm{Cr}_{2} \mathrm{O}_{3}$ was added at a concentration of about $0.5 \mathrm{wt} \%$ to all of the glasses. In order to improve VHT performance, $\mathrm{ZrO}_{2}$ was maintained at high concentrations ( $>5 \mathrm{wt} \%$ ) and $\mathrm{SnO}_{2}$ was added to all of the glasses [47]. Since the target $\mathrm{SO}_{3}$ loadings were higher in ORPLB glasses than for the ORPLA glasses, $\mathrm{V}_{2} \mathrm{O}_{5}$ was added to all of the ORPLB glass formulations. In addition, based on the results of Region A glass testing, the $\mathrm{Na}_{2} \mathrm{O}$ concentration was reduced to $24 \mathrm{wt} \%$ in ORPLB3 and ORPLB4. Lessons learned from Region A glass development, which are listed above, were valuable in guiding the Region $\mathrm{B}$ glass development work. 
The Catholic University of America Vitreous State Laboratory
Enhanced LAW Glass Formulation Testing Final Report, VSL-07R1130-1, Rev. 0

Target and analyzed compositions of the ORPLB glasses are given in Table 2.12. Testing and analysis of the glasses followed the same methods used for ORPLA glasses, which are described in Section 2.1.2. As is evident from the table, the target and analyzed compositions show good agreement. Glass samples were heat treated for 20 hours at $950^{\circ} \mathrm{C}$ and then evaluated for secondary phases. Observations of the as-melted, and heat treated glasses are given in Table 2.13. All of the as-melted glasses appeared clear with one containing small amounts $(<0.1 \mathrm{vol} \%)$ of crystals. All of the heat treated glasses showed small amounts of spinel crystals at concentrations not greater than 0.2 vol\%.

The sulfate solubilities of the ORPLB glass compositions were assessed by both batch saturation and bubbling tests. The batch saturation tests are described in Section 2.1.2. The results of batch saturation tests are given in Figure 2.1 and Table 2.14. In the bubbling test, a sample of the test glass that does not contain any sulfate is melted in a platinum crucible and held at a constant temperature of $1150^{\circ} \mathrm{C}$. Mixtures of $\mathrm{SO}_{2}$ and $\mathrm{O}_{2}$ are then bubbled through the glass melt at controlled flow rates through a platinum tube. From the flow rates and the temperature, together with known thermodynamic data, the partial pressure of $\mathrm{SO}_{3}$ can be calculated. Samples of the glass melt are removed at selected time intervals and subjected to analysis by XRF to determine their sulfur content. Prior to analysis, the glass samples are ground and washed to remove any sulfate phase that might adhere to the sample in order to determine only the sulfate that is dissolved in the glass. Figure 2.5 shows the results of these tests for one of the ORPLB glasses, ORPLB4; also shown are the results for a previously tested high sulfate ORP LAW Envelope A glass LAWA161 [2], and an ORPLE glass formulation (see Section 2.5.2). The results show that the ORPLB4 glass has lower sulfate solubility than the other two glasses. This is expected, because as indicated in Figure 2.5, ORPLB4 has higher $\mathrm{Na}_{2} \mathrm{O}$ concentration than the other two glasses. The results of sulfate solubility determinations by batch saturation tests and gas bubbling tests for ORPLB glasses are given in Table 2.14. The sulfate solubilities varied from 0.52 to $0.58 \mathrm{wt} \%$ by batch saturation tests and 0.62 to $0.70 \mathrm{wt} \%$ by bubbling tests.

VHT and PCT results are summarized in Table 2.15 and illustrated in Figures 2.2 and 2.3. Similar to ORPLA glasses, VHT alteration rates were measured using one sample with nominal $\mathrm{SO}_{3}$ concentration and another from the remelt with $4 \mathrm{wt} \% \mathrm{SO}_{3}$. VHT results show that only ORPLB4 met the contract requirement that alteration rate be less than $50 \mathrm{~g} / \mathrm{m}^{2} /$ day. Again, this was not unexpected because glasses were formulated with the objective of attaining the highest possible $\mathrm{Na}_{2} \mathrm{O}$ loading and VHT performance becomes the limiting factor in these formulations. PCT releases for the glasses given in Table 2.15 and Figure 2.3 show that all of the glasses met the ILAW product quality requirement of normalized mass loss of less than $2 \mathrm{~g} / \mathrm{m}^{2}$ for $\mathrm{B}, \mathrm{Na}$, and $\mathrm{Si}$. The viscosities and electrical conductivities of the glasses at select temperatures are given in Table 2.16. All of the viscosity and electrical conductivity values are in the acceptable range for processing. However, as intended, the viscosities of the glasses are generally on the high end of acceptability in order to reduce refractory corrosion. Due to the high alkali content of the new ORPLB glass formulations, K-3 refractory corrosion was a significant concern and, therefore, all of the glasses were tested for their K3 corrosion characteristics. K-3 refractory corrosion test results for the glasses are given in Table 2.17 and Figure 2.4. All four of the ORPLB glasses met the guidance of no more than 0.040 inches of neck loss in the K-3 corrosion test. 
Of the four ORPLB glass formulations tested, only one, ORPLB4, met all processing and product quality requirements and was, therefore, selected for melter testing. The measured properties of the glass ORPLB4 are compared to the ILAW performance requirements [45, 46] in Table 2.18. Density and glass transition temperature measurements, and canister centerline cooling (CCC) heat treatment were not conducted on ORPLB4 glass. Examination of cooled ORPLB4 glass samples from the DM10 melter tests showed little crystallization, indicating that the glass is unlikely to show substantial crystallization on CCC heat treatment.

The composition of the ORPLB4 glass used in melter tests is given in Table 2.19 along with the oxide contributions from the LAW AN-107 waste simulant and from the glass former additives. The simulant was procured with no $\mathrm{SO}_{3}$ and the sulfur concentration was increased in steps during the melter tests by adding the appropriate amounts of $\mathrm{Na}_{2} \mathrm{SO}_{4}$ and $\mathrm{NaOH}$ to the feed. The melter feed was procured at a $\mathrm{Na}_{2} \mathrm{O}$ concentration of $22.89 \mathrm{wt} \%$ in order to accommodate $\mathrm{Na}_{2} \mathrm{SO}_{4}$ and $\mathrm{NaOH}$ additions, without increasing the $\mathrm{Na}_{2} \mathrm{O}$ concentration above $24.0 \mathrm{wt} \%$. The types and amounts of glass former additives used to prepare the melter feed along with the target feed properties are given in Table 2.20a. The glass former additives are the same as those planned for use at the WTP, with the exception of chromium, tin, and vanadium, which are new additives. The amounts of $\mathrm{Na}_{2} \mathrm{SO}_{4}$ and $\mathrm{NaOH}$ added to the feed to obtain $24 \mathrm{wt} \% \mathrm{Na}_{2} \mathrm{O}$ and 0.60 to $1.0 \mathrm{wt} \% \mathrm{SO}_{3}$ are given in Table 2.20b.

\subsection{Region C (ORPLC) Waste Simulant and Glass Formulation}

Glass formulation development and testing for Region C (ORPLC) were based on the composition of LAW material from Hanford tank AN-104. Details of the waste simulant, and glass formulation development and testing are given below.

\subsubsection{Region C (ORPLC) Waste Simulant}

A LAW Envelope A waste simulant based on the composition data for tank AN-104, as given in a WTP Test Specification [40], was used as the basis for ORPLC glass formulations. The base waste composition incorporates TFCOUP [41] data, actual waste analysis data, and WTP flow sheet information. The sodium concentration in the simulant includes a $2.5 \%$ increase to account for sodium additions in pretreatment [12, 42]. The nominal concentration, expressed in terms of the sodium molarity, was estimated on the basis of melter feed rheology tests on similar formulations [43, 44]. The concentration of the simulant used in melter tests was 8.0 molar sodium. This is higher than that used in previous melter tests $[17,24]$ because of the higher waste loading in the ORPLC glasses.

The nominal simulant formulation is given in Table 2.21. The LAW AN-104 simulant is a solution of predominantly sodium, nitrate, nitrite, chlorine and sulfate. Preparation of the waste simulant and melter feed were done in a manner similar to that for ORPLA simulant, which is described in Section 2.1.1. 
The Catholic University of America

Vitreous State Laboratory
Enhanced LAW Glass Formulation Testing

Final Report, VSL-07R1130-1, Rev. 0

\subsubsection{Region C (ORPLC) Glass Formulation}

Glass formulation development for Region C (ORPLC) was based on the composition of the LAW AN-104 waste stream. The target $\mathrm{SO}_{3}$ loading in the ORPLC glass was 0.45 to $0.75 \mathrm{wt} \%$. Five crucible melts were prepared in an effort to identify a glass formulation that meets all processing and product quality requirements. Similar to the ORPLA and ORPLB glasses, due to their high $\mathrm{Na}_{2} \mathrm{O}$ concentrations, the properties of most concern were VHT alteration rate and K-3 refractory corrosion. In order to reduce K-3 refractory corrosion, $\mathrm{Al}_{2} \mathrm{O}_{3}$, $\mathrm{SiO}_{2}$, and $\mathrm{ZrO}_{2}$ concentrations were maintained at high levels in all the glasses, and $\mathrm{Cr}_{2} \mathrm{O}_{3}$ was added at a concentration of about $0.5 \mathrm{wt} \%$ to all of the glasses. In order to improve VHT performance, $\mathrm{ZrO}_{2}$ was maintained at high concentrations ( $>3.4 \mathrm{wt} \%$ ) and $\mathrm{SnO}_{2}$ was added to all of the glasses [47]. Since the target $\mathrm{SO}_{3}$ loadings were higher in ORPLC glasses than for the ORPLA glasses, $\mathrm{V}_{2} \mathrm{O}_{5}$ was added to all of the ORPLC glass formulations.

Target and analyzed compositions of the ORPLC glasses are given in Table 2.22. Testing and analysis of the glasses followed the same methods used for ORPLA glasses, which are described in Section 2.1.2. As is evident from the table, the target and analyzed compositions show good agreement. Glass samples were heat treated for 20 hours at $950^{\circ} \mathrm{C}$ and then evaluated for secondary phases. Observations of the as-melted and heat treated glasses are given in Table 2.23. All of the as-melted glasses appeared clear with very small amounts $(<0.1$ vol\%) of crystals. The heat treated glasses also showed little crystallization $(<0.3 \mathrm{vol} \%)$.

The sulfate solubilities of the ORPLC glass compositions were assessed by both batch saturation and bubbling tests. The batch saturation tests are described in Section 2.1.2 and the bubbling tests are described in Section 2.2.2. The results of the tests are given in Figure 2.1 and Table 2.24. The sulfate solubilities of the ORPLC glasses varied from 0.56 to $0.70 \mathrm{wt} \%$ by batch saturation tests and 0.58 to $1.09 \mathrm{wt} \%$ by bubbling tests.

VHT and PCT results are summarized in Table 2.25 and illustrated in Figures 2.2 and 2.3. Similar to ORPLA and ORPLB glasses, VHT was measured on two samples each for all the glasses. Although all of the glasses met the PCT release limits, only ORPLC5 passed the VHT contract requirement that alteration rate be less than $50 \mathrm{~g} / \mathrm{m}^{2} /$ day. Again, this was not unexpected because glasses were formulated with the objective of attaining the highest possible $\mathrm{Na}_{2} \mathrm{O}$ loading and VHT performance becomes the limiting factor in these formulations. The viscosities and electrical conductivities of three of the ORPLC glasses at select temperatures are given in Table 2.26. All of the viscosity and electrical conductivity values are in the acceptable range for processing. All of the ORPLC glasses were tested for their K3 corrosion characteristics. K-3 refractory corrosion test results for the glasses are given in Table 2.27 and Figure 2.4. Only two of the glasses met the guidance of no more than 0.040 inches of neck loss in the K-3 corrosion test.

Of the five ORPLC glass formulations tested, only one, ORPLC5, met all processing and product quality requirements and was, therefore, selected for melter testing. The measured 
The Catholic University of America

Vitreous State Laboratory
Enhanced LAW Glass Formulation Testing

Final Report, VSL-07R1130-1, Rev. 0

properties of the glass ORPLC5 are compared to the ILAW performance requirements [45, 46] in Table 2.28. Density and glass transition temperature measurements, and canister centerline cooling (CCC) heat treatment were not conducted on ORPLC5 glass. Examination of cooled ORPLC5 glass samples from the melter tests showed little crystallization, indicating that the glass is unlikely to show substantial crystallization on CCC heat treatment. Again, an acceptable Region $C$ glass for melter testing was more easily identified because it was possible to build on the results from the Region A and B testing, as was the intended strategy. ORPLC5 was modeled after ORPLB4 with adjustment for $\mathrm{K}_{2} \mathrm{O}$ content of the Region $\mathrm{C}$ waste stream.

The composition of the ORPLC5 glass used in melter tests is given in Table 2.29 along with the oxide contributions from the LAW AN-104 waste simulant and from the glass former additives. The simulant was procured with no $\mathrm{SO}_{3}$ and the sulfur concentration was increased in steps during the melter tests by adding the appropriate amounts of $\mathrm{Na}_{2} \mathrm{SO}_{4}$ and $\mathrm{NaOH}$ to the feed. The melter feed was procured at a $\mathrm{Na}_{2} \mathrm{O}$ concentration of $22.11 \mathrm{wt} \%$ in order to accommodate $\mathrm{Na}_{2} \mathrm{SO}_{4}$ and $\mathrm{NaOH}$ additions without increasing the $\mathrm{Na}_{2} \mathrm{O}$ concentration above $23.57 \mathrm{wt} \%$. The types and amounts of glass former additives used to prepare the melter feed along with the target feed properties are given in Table 2.30a. The glass former additives are the same as those planned for use at the WTP, with the exception of chromium, tin, and vanadium, which are new additives. The amounts of $\mathrm{Na}_{2} \mathrm{SO}_{4}$ and $\mathrm{NaOH}$ added to the feed to obtain $23.57 \mathrm{wt} \% \mathrm{Na}_{2} \mathrm{O}$ and 0.0 to $0.9 \mathrm{wt} \% \mathrm{SO}_{3}$ are given in Table 2.30b.

\subsection{Region D (ORPLD) Waste Simulant and Glass Formulation}

Glass formulation development and testing for Region D (ORPLD) were based on the composition of LAW material from Hanford tank AN-102. Details of the waste simulant, and glass formulation development and testing are given below.

\subsubsection{Region D (ORPLD) Waste Simulant}

A LAW Envelope C waste simulant based on the composition data for tank AN-102, as given in a WTP Test Specification [40], was used as the basis for ORPLD glass formulations. The base waste composition incorporates TFCOUP [41] data, actual waste analysis data, and WTP flow sheet information. The sodium concentration in the simulant includes a $17.65 \%$ increase to account for sodium additions in pretreatment [12, 42]. The nominal concentration, expressed in terms of the sodium molarity, was estimated on the basis of melter feed rheology tests on similar formulations [43, 44]. The concentration of the simulant used in melter tests was 8.0 molar sodium. This is higher than that used in previous melter tests [21, 24] because of the higher waste loading in the ORPLD glasses.

The nominal simulant formulation is given in Table 2.31. The LAW AN-102 simulant is a solution of predominantly sodium, nitrate, nitrite, and sulfate. Preparation of the waste simulant and melter feed were done in a manner similar to that for ORPLA simulant, which is described in Section 2.1.1. 
The Catholic University of America

Vitreous State Laboratory
Enhanced LAW Glass Formulation Testing

Final Report, VSL-07R1130-1, Rev. 0

\subsubsection{Region D (ORPLD) Glass Formulation}

Glass formulation development for Region D (ORPLD) was based on the composition of the LAW AN-102 waste stream. The target $\mathrm{SO}_{3}$ loading in the ORPLD glass was 0.6 to $1.2 \mathrm{wt} \%$. Three crucible melts were prepared in an effort to identify a glass formulation that meets all processing and product quality requirements. Since target $\mathrm{SO}_{3}$ loadings were higher in ORPLD glasses than for ORPLA, ORPLB, and ORPLC glasses, $\mathrm{V}_{2} \mathrm{O}_{5}$ was added to all of the ORPLD glass formulations. The concentration of $\mathrm{CaO}$, which facilitates higher $\mathrm{SO}_{3}$ loadings, was increased in all three glasses and $\mathrm{Li}_{2} \mathrm{O}$, which is another additive that is very beneficial in increasing $\mathrm{SO}_{3}$ loadings, was added in small amounts to two of the glasses. Higher $\mathrm{Li}_{2} \mathrm{O}$ concentrations could not be employed because the glass already contains a high concentration (21 wt\%) of $\mathrm{Na}_{2} \mathrm{O}$ and higher combined alkali loadings will have adverse effects on PCT, VHT, and K-3 refractory corrosion. In order to reduce K-3 refractory corrosion, $\mathrm{Cr}_{2} \mathrm{O}_{3}$ was added at a concentration of about $0.5 \mathrm{wt} \%$ to all of the glasses. Region $\mathrm{D}$ glass development work benefited greatly from Regions A, B, C and E testing, as was the intended strategy. In addition, the $\mathrm{Na}_{2} \mathrm{O}$ concentration was reduced, making Region D glasses comparable to previously tested ORP glasses such as LAWA161 [2] and LAWC100 [5].

Target and analyzed compositions of the ORPLD glasses are given in Table 2.32. Testing and analysis of the glasses followed the same methods used for ORPLA glasses, which are described in Section 2.1.2. As is evident from the table, the target and analyzed compositions show good agreement. Glass samples were heat treated for 20 hours at $950^{\circ} \mathrm{C}$ and evaluated for secondary phases. Observations of the as-melted, and heat treated glasses are given in Table 2.33. All of the as-melted glasses appeared clear with small amounts ( $0.2 \mathrm{vol} \%$ or less) of crystals. The heat treated glasses also showed little crystallization ( $0.2 \mathrm{vol} \%$ or less).

The sulfate solubilities of the ORPLD glass compositions were assessed by batch saturation tests. The batch saturation tests are described in Section 2.1.2 and the results of the tests are given in Figure 2.1 and Table 2.34. The sulfate solubilities of the ORPLD glasses varied from 0.70 to $0.89 \mathrm{wt} \%$ by batch saturation tests. Region D glasses were the last ones tested. At this time, the equipment used to do sulfate saturation by bubbling failed and had to be repaired. It was, therefore, decided to use the sulfate saturation by batch testing to make the glass selection rather than delay the melter testing and reporting schedule. In addition, comparisons were made to other ORP glasses (ORPLE12, ORPLE4, ORPLE5, LAWA161, LAWC100) to make the judgment that the glass will likely meet or exceed sulfate loading in the feed of about $1.0 \mathrm{wt} \%$. VHT and PCT results are summarized in Table 2.35 and illustrated in Figures 2.2 and 2.3. All three of the glasses met the PCT release and VHT alteration rate limits. The viscosities and electrical conductivities of ORPLD1 glass at select temperatures are given in Table 2.36. The viscosities and electrical conductivities of the other two glasses were not measured because they did not meet the K-3 refractory corrosion criterion. K-3 refractory corrosion test results for the glasses are given in Table 2.37 and Figure 2.4. Only ORPLD1 met the guidance of no more than 0.040 inches of neck loss in the K-3 corrosion test. 
Of the three ORPLD glass formulations tested, only one, ORPLD1, met all processing and product quality requirements and was, therefore, selected for melter testing. The measured properties of the glass ORPLD1 are compared to the ILAW performance requirements [45, 46] in Table 2.38. Density and glass transition temperature measurements, and canister centerline cooling (CCC) heat treatments were not conducted on ORPLD1 glass. Examination of cooled ORPLD1 glass samples from the melter showed little crystallization, indicating that the glass is unlikely to show substantial crystallization on CCC heat treatment.

The composition of the ORPLD1 glass used in melter tests is given in Table 2.39 along with the oxide contributions from the LAW AN-102 waste simulant and from the glass former additives. The simulant was procured with no $\mathrm{SO}_{3}$ and the sulfur concentration was increased in steps during the melter tests by adding the appropriate amounts of $\mathrm{Na}_{2} \mathrm{SO}_{4}$ and $\mathrm{NaOH}$ to the feed. The melter feed was procured at a $\mathrm{Na}_{2} \mathrm{O}$ concentration of $19.37 \mathrm{wt} \%$ in order to accommodate $\mathrm{Na}_{2} \mathrm{SO}_{4}$ and $\mathrm{NaOH}$ additions, without increasing the $\mathrm{Na}_{2} \mathrm{O}$ concentration above $21.0 \mathrm{wt} \%$. The types and amounts of glass former additives used to prepare the melter feed along with the target feed properties are given in Table 2.40a. The glass former additives are the same as those planned for use at the WTP, with the exception of chromium and vanadium, which are new additives. The amounts of $\mathrm{Na}_{2} \mathrm{SO}_{4}$ and $\mathrm{NaOH}$ added to the feed to obtain $21.0 \mathrm{wt} \% \mathrm{Na}_{2} \mathrm{O}$ and 0.0 to $1.3 \mathrm{wt} \% \mathrm{SO}_{3}$ are given in Table 2.40b.

\subsection{Region E (ORPLE) Waste Simulant and Glass Formulation}

Glass formulation development and testing for Region E (ORPLE) were based on the composition of LAW material from Hanford tank AZ-101. Details of the waste simulant, and glass formulation development and testing are given below.

\subsubsection{Region E (ORPLE) Waste Simulant}

A LAW Envelope B waste simulant based on the composition data for tank AZ-101, as given in a WTP Test Specification [40], was used as the basis for ORPLA glass formulations. The base waste composition incorporates TFCOUP [41] data, actual waste analysis data, and WTP flow sheet information. The sodium concentration in the simulant includes a $5.33 \%$ increase to account for sodium additions in pretreatment [12, 42]. The nominal concentration, expressed in terms of the sodium molarity, was estimated on the basis of melter feed rheology tests on similar formulations [43, 44]. The concentration of the simulant used in melter tests was 7.0 molar sodium. This is higher than that used in previous melter tests $[18,23]$ because of the higher waste loading in the ORPLE glasses.

The nominal simulant formulation is given in Table 2.41. The LAW AZ-101 simulant is a solution of predominantly sodium, nitrate, nitrite, and sulfate. Preparation of the waste simulant and melter feed were done in a manner similar to that for ORPLA simulant, which is described in Section 2.1.1. 
The Catholic University of America

Vitreous State Laboratory
Enhanced LAW Glass Formulation Testing Final Report, VSL-07R1130-1, Rev. 0

\subsubsection{Region E (ORPLE) Glass Formulation}

Glass formulation development for Region E (ORPLE) was based on the composition of the LAW AZ-101 waste stream. The target $\mathrm{SO}_{3}$ loading in the ORPLE glass was 0.8 to $1.4 \mathrm{wt} \%$. Twelve crucible melts were prepared and characterized to identify a glass formulation that meets all processing and product quality requirements. Since target $\mathrm{SO}_{3}$ loadings were the highest in ORPLE glasses, the $\mathrm{CaO}$ concentration was maintained at a high level (> $9 \mathrm{wt} \%)$ and $\mathrm{Li}_{2} \mathrm{O}$ and $\mathrm{V}_{2} \mathrm{O}_{5}$ were added to all of the ORPLE glass formulations. In order to reduce K-3 refractory corrosion, $\mathrm{Cr}_{2} \mathrm{O}_{3}$ was added at a concentration of about $0.5 \mathrm{wt} \%$ to some of the glasses, especially those with $\mathrm{Li}_{2} \mathrm{O}$ as an additive. Five glasses, OPRLE1-ORPLE5, were tested initially, followed by ORPLE6 to ORPLE12 in the next set. ORPLE1 to ORPLE5 testing showed that addition of $\mathrm{Li}_{2} \mathrm{O}$ is beneficial in increasing sulfate solubility but at the expense of K-3 corrosion, that VHT becomes an issue at higher $\mathrm{Na}_{2} \mathrm{O}$ concentrations, and that the target $\mathrm{SO}_{3}$ loading of $1.25 \mathrm{wt} \%$ can be achieved. Since higher sulfate loading was the primary focus of Region $\mathrm{E}$ glass formulation, and since ORPLE1 showed the highest sulfate solubility, glasses ORPLE6 to ORPLE12 looked at variations in the composition of ORPLE1. All of the additives were varied (0.1 to $1.2 \mathrm{wt} \%$ ) in one glass or another, with two to four oxide components changed in any one glass.

Target and analyzed compositions of the ORPLE glasses are given in Table 2.42. Testing and analysis of the glasses followed the same methods used for ORPLA glasses, which are described in Section 2.1.2. As is evident from the table, the target and analyzed compositions show good agreement. Glass samples were heat treated for 20 hours at $950^{\circ} \mathrm{C}$ and then evaluated for secondary phases. Observations of the as-melted, and heat treated glasses are given in Table 2.43. All of the as-melted glasses appeared clear with no crystals. The heat treated glasses also showed little crystallization ( 0.2 vol\% or less).

The sulfate solubilities of the ORPLE glass compositions were assessed by batch saturation and bubbling tests. The batch saturation tests are described in Section 2.1.2 and the bubbling tests are described in Section 2.2.2. The results of the tests are given in Figures 2.1 and 2.5 and Table 2.44. The sulfate solubilities of the ORPLE glasses varied from 1.18 to $1.66 \mathrm{wt} \%$ by batch saturation tests and 1.38 to 1.66 wt\% by bubbling tests. VHT and PCT results are summarized in Table 2.45 and illustrated in Figures 2.2 and 2.3. All twelve glasses met the PCT release limits and all but one met the VHT alteration rate limit. Since ORPLE glasses have comparatively lower alkali concentrations and VHT performance was not a major concern, the VHT measurements were done only on samples with the nominal $\mathrm{SO}_{3}$ concentration. The viscosities and electrical conductivities of ORPLE glasses at select temperatures, all of which are within acceptable limits, are given in Table 2.46. K-3 refractory corrosion test results for the glasses are given in Table 2.47 and Figure 2.4. Only two glasses, ORPLE7 and ORPLE12, met the guidance of no more than 0.040 inches of neck loss in the K-3 corrosion test.

Of the ten ORPLE glass formulations tested, only two, ORPLE7 and ORPLE12, met all processing and product quality requirements. Compared to other ORPLE glasses, the major difference is that ORPLE7 and ORPLE12 contained $\mathrm{Cr}_{2} \mathrm{O}_{3}$ and lower concentrations of $\mathrm{Li}_{2} \mathrm{O}$, 
The Catholic University of America

Vitreous State Laboratory
Enhanced LAW Glass Formulation Testing

Final Report, VSL-07R1130-1, Rev. 0

$\mathrm{CaO}$, or $\mathrm{B}_{2} \mathrm{O}_{3}$. Of the two, ORPLE12 showed higher sulfate solubility and better performance on VHT, and therefore was selected for melter testing. The measured properties of the glass ORPLE12 are compared to the ILAW performance requirements [45, 46] in Table 2.48. Density and glass transition temperature measurements, and canister centerline cooling (CCC) heat treatments were not conducted on ORPLE12 glass. Examination of cooled ORPLE12 glass samples from the melter tests showed little crystallization, indicating that the glass is unlikely to show substantial crystallization on CCC heat treatment.

The composition of the ORPLE12 glass used in melter tests is given in Table 2.49 along with the oxide contributions from the LAW AZ-101 waste simulant and from the glass former additives. The simulant was procured with $1.25 \mathrm{wt} \% \mathrm{SO}_{3}$ and the sulfur concentration was increased in steps during the melter tests by adding the appropriate amounts of $\mathrm{Na}_{2} \mathrm{SO}_{4}$ and $\mathrm{NaOH}$ to the feed. The melter feed was procured at a $\mathrm{Na}_{2} \mathrm{O}$ concentration of $15.81 \mathrm{wt} \%$ in order to accommodate $\mathrm{Na}_{2} \mathrm{SO}_{4}$ and $\mathrm{NaOH}$ additions, without increasing the $\mathrm{Na}_{2} \mathrm{O}$ concentration above $16.0 \mathrm{wt} \%$. The types and amounts of glass former additives used to prepare the melter feed along with the target feed properties are given in Table 2.50a. The glass former additives are the same as those planned for use at the WTP, with the exception of chromium and vanadium, which are new additives. The amounts of $\mathrm{Na}_{2} \mathrm{SO}_{4}$ and $\mathrm{NaOH}$ added to the feed to obtain 16.0 wt $\% \mathrm{Na}_{2} \mathrm{O}$ and 1.25 to 1.75 wt\% $\mathrm{SO}_{3}$ are given in Table 2.50b.

\subsection{Sugar Additions}

With high nitrate feeds, the addition of reductants is necessary in order to control melt foaming. Sugar, which was used for this purpose at West Valley, has also been selected as the baseline reductant for the WTP. The amount of sugar required increases with the amount of nitrates present in the feed and decreases with the amount of waste organics present in the feed, which themselves act as reductants. Excessive additions of reductants can be deleterious, leading to over-reduction of the melt and formation of sulfides and molten metals. Consequently, the oxidants and reductants in the feed must be suitably balanced. The basis for achieving this balance was developed by VSL and EnergySolutions for the vitrification of high-sodium-nitrate feeds at Savannah River's M-Area and has been successfully applied to the processing of a wide variety of simulated WTP feeds over the past six years. In developing this approach, we elected to conservatively adopt the most reducing potential reaction as the basis for the definition of a "sugar" or stoichiometric ratio of 1.0 as a result of concerns for over-reducing the melt. Such a reaction, using sodium salts as an example, is:

$$
\mathrm{C}_{12} \mathrm{H}_{22} \mathrm{O}_{11}+8 \mathrm{NaNO}_{3}=8 \mathrm{CO}_{2}+4 \mathrm{CO}+4 \mathrm{~N}_{2}+11 \mathrm{H}_{2} \mathrm{O}+4 \mathrm{Na}_{2} \mathrm{O}
$$

Fundamentally, the basis that is selected is simply a convention, since the precise stoichiometry of the reactions involved is neither known nor constant under the conditions prevailing in the melter. However, with this convention, a sugar ratio of 1.0 corresponds to one mole of sucrose per eight moles of nitrate or, more generally, 1.5 moles of organic carbon per mole of nitrate. It is then expected that significantly less sugar than this will be required in 
practice. The empirically determined amount required to successfully control melt foaming without significantly reducing the glass melt was found to correspond to a ratio of 0.5 when any nitrites present were counted as nitrates (i.e., 0.75 moles of organic carbon per mole of nitrate + nitrite). This approach has been employed for all WTP melter testing. It is, however, expected that slight variations around the nominal value of 0.5 may be necessary to account for differences in the reducing power of waste organics in comparison to sugar, particularly for LAW streams that are high in organics.

As an example, the calculation of the amount of sugar needed for the present LAW AN-105 (Envelope A) feed to achieve a sugar ratio of 0.5 proceeds as follows:

- $\quad$ One liter of 8 Molar sodium simulant contains 1.857 moles of nitrite and 2.048 moles of nitrate, giving a total of 3.905 moles of NOx (see Table 2.1)

- Required total amount of organic carbon for a sugar ratio of 0.5 is $3.905 \times 0.75=2.929$ moles

- One liter of simulant contains 0.174 moles of organic carbon (see Table 2.1)

- $\quad$ Therefore, $2.929-0.174=2.755$ moles of organic carbon must be added.

Since the molecular weight of sucrose is $342 \mathrm{~g}, 2.755 \times 342 / 12=78.5$ g sugar must be added per liter of simulant, as shown in Table 2.10.a.

\subsection{Analysis of Melter Feed Samples}

\subsubsection{General Properties}

Feed samples were analyzed from melter tests to confirm physical properties and chemical composition. Samples were taken from residual melter feed from most of the test segments. Sample names, sampling dates, measured properties and comparisons with feed analysis for similar waste streams [2, 3, 5, 6, 17, 18, 21-24, 49, 50] are provided in Table 2.51. The average measured glass yield for the melter samples was less than 6\% below the target values (on a mass per unit mass basis) provided in Tables 2.10.a, 2.20.a, 2.30.a, 2.40.a, and 2.50.a, validating the use of the target value for calculating glass production rates. This small low bias for glass yield and density is observed in most LAW feeds due perhaps to high estimates in the purity of the additives as well as water added during the transfer of feed [51]. In all but the AN-102 (Sub-Envelope C2) waste, the measured densities and glass yields are lower in samples from the current tests due to the greater proportion of sodium in the feed, which is contained in the soluble fraction of the feed. Similarly, the measured $\mathrm{pH}$ is higher in the samples from the current tests since much of the additional sodium is introduced to the feed as sodium hydroxide. The trend is less evident for the AN-102 (Sub-Envelope C2) feed, presumably due to the effect of the somewhat lower water content. 
The Catholic University of America

Vitreous State Laboratory
Enhanced LAW Glass Formulation Testing

Final Report, VSL-07R1130-1, Rev. 0

\subsubsection{Chemical Composition}

The chemical compositions of the feed samples were determined by first making a glass from the feed sample via crucible melt. The glass was subsequently crushed and analyzed directly by XRF. The boron and lithium oxide target values were used for normalizing the XRF data since their concentration was not determined by XRF. The XRF-analyzed compositions of the feed samples are provided in Table 2.52. The results generally show good agreement with the target composition for the major components. Of the oxides with a target concentration of one percent or greater, the XRF values for magnesium and zirconium in Test 1 samples, and for vanadium, tin, and sulfur oxides, as well as sodium and silicon in Test 5 samples, had deviations of greater than $10 \%$ from target. The deviations in tin and vanadium were also observed in the product glasses and may be attributable to a potential analytical bias for these elements using the XRF [2, 6, 51] (see Section 4.1). Deficits of measured magnesium oxide in the feed samples were not measured in the product glass; this trend has been observed in several previous studies $[3,4,9,10,49-52]$ but the origin of the effect remains unclear.

The soda deficit and silica surplus measured in the feed sample from Test 5 (Region D) was also observed in product glasses (see Section 4.1). This trend and the comparison of measured physical properties suggest that either the waste simulant was deficient in sodium or the proportion of simulant to glass forming additives was low. However, direct analysis of the waste simulant and review of feed batching records indicate these were not the causes of the disparity. Excessive foaming occurred during the preparation of these feeds resulting in the loss of several kilograms of material. If the lost portion of the feed were enriched in sodium, this may account for the sodium deficit. The feed foaming is most likely a result of carbon dioxide release as the $\mathrm{pH}$ of the basic feed is reduced during the addition of boric acid to the feed.

Volatile minor elements such as sulfur and chlorine are, as expected, below target due to loss during crucible melting. The target sulfur concentration in the feed, which is important for determining sulfur retention in the glass, is verified from the simulant vendor's batching sheets. The additional amounts of sulfur added at VSL are calculated, checked, and weighed out using calibrated balances. Measured chromium concentrations are about half the target concentrations, as intended, since the remaining chromium is incorporated into the glass pool as a result of corrosion of melter bricks and Inconel components (see Section 4.1). Even though addition of $\mathrm{Cr}_{2} \mathrm{O}_{3}$ reduces the corrosion rate, some level of corrosion of the K-3 brick will always occur. Titanium oxide was measured in the feed samples from about a tenth to a quarter of a weight percent, even though it was not included in the target composition. Similar observations were made in previous tests with LAW melter feeds $[9,10,13,16-18,51]$ and is due to its presence as a contaminant in the glass forming additives, most notably kyanite [2]. Common elements such as iron, phosphorus, and potassium, which are typical impurities in bulk chemicals, are overrepresented when the constituent is a minor component. 


\section{SECTION 3.0 DM10 TESTS}

Melter tests were conducted on the DM10 with the LAW simulants from 1/23/07 to $1 / 26 / 07$ and 6/6/07 to $7 / 18 / 07$ to determine the maximum sulfur concentration that can be processed without forming secondary phases for each of the five compositional regions. These tests produced over half a metric ton of glass from more than a metric ton of feed. Tables 3.1 3.5 provide summaries of the DM10 tests, including run times, the amount of sulfur in the feed, the amount of feed processed, the amount of feed sulfur retained in the glass product, observations of secondary phases, key processing parameters, and measured concentrations of gaseous species. The tests, listed in the order in which they were performed, were as follows:

- Test 1 (Region E): Five nominally 14-hour feeding segments with LAW AZ-101/Sub-Envelope B1 wastes targeting a $\mathrm{Na}_{2} \mathrm{O}$ concentration of $16 \mathrm{wt} \%$ in the glass product. Segments tested $\mathrm{SO}_{3}$ concentrations of $1.25,1.5,1.625$, and $1.75 \mathrm{wt} \%$ in the glass product (assuming total retention). Based on the result of analysis of product glasses, the chromium feed concentrations were reduced after two segments, as well as for all future tests, in order to compensate for chromium leached from melter components.

- Test 2 (Region A): Six nominally 14-hour feeding segments with LAW AN-105/Sub-Envelope A1 wastes targeting a $\mathrm{Na}_{2} \mathrm{O}$ concentration of $24 \mathrm{wt} \%$ in the glass product. Segments tested $\mathrm{SO}_{3}$ concentrations of $0.1,0.2,0.3,0.4,0.5$, and $0.6 \mathrm{wt} \%$ in the glass product (assuming total retention). No secondary phases were observed at sulfur concentrations of twice the maximum of the range stipulated for testing. Significant foaming occurred during this test, yielding a foamy glass product.

- Test 3 (Region B): Four nominally 14-hour feeding segments with LAW AN-107/Sub-Envelope C1 wastes targeting a $\mathrm{Na}_{2} \mathrm{O}$ concentration of $24 \mathrm{wt} \%$ in the glass product. Segments tested $\mathrm{SO}_{3}$ concentrations of $0.6,0.7,0.85$, and $1.0 \mathrm{wt} \%$ in the glass product (assuming total retention). Significant foaming occurred during this test, yielding a foamy glass product.

- Test 4 (Region C): Three nominally 14-hour feeding segments with LAW AN-104/Sub-Envelope A3 wastes targeting a $\mathrm{Na}_{2} \mathrm{O}$ concentration of $23.6 \mathrm{wt} \%$ in the glass product. Segments tested $\mathrm{SO}_{3}$ concentrations of $0.7,0.8$, and $0.9 \mathrm{wt} \%$ in the glass product (assuming total retention). Additional short test segments with sulfur free feed to reduce sulfur concentration in the glass pool were conducted in between test segments $4 \mathrm{~A}$ and $4 \mathrm{C}$ as well as after test segment $4 \mathrm{D}$. Significant foaming occurred during this test, yielding a foamy glass product. 
- Test 5 (Region D): Four nominally 14-hour feeding segments with LAW AN-102/Sub-Envelope C2 wastes targeting a $\mathrm{Na}_{2} \mathrm{O}$ concentration of $21 \mathrm{wt} \%$ in the glass product. Segments tested $\mathrm{SO}_{3}$ concentrations of $0.7,0.9,1.1$, and $1.3 \mathrm{wt} \%$ in the glass product (assuming total retention).

The principal objective of these tests was to determine, for each feed, the maximum amount of sulfur that can be fed into the melter without forming secondary sulfate phases. The bubbling rate was adjusted to maintain the target production rate of $2250 \mathrm{~kg} / \mathrm{m}^{2} / \mathrm{day}$ and a complete cold cap. Test segment durations of 12 to 18 hours were selected since, at the target glass production rate, this provided three melt pool turnovers $(24 \mathrm{~kg})$ for each sulfur concentration. Sugar was added to the feed at a stoichiometric carbon ratio of 0.5 for all of the melter tests. At the end of each test segment, dip samples were taken to detect the presence of separated sulfur phases on the glass pool surface. The melt surface was considered free of a sulfate layer if no visible secondary sulfate phases were observed on any of the three dip samples. If a sulfate layer was detected on the melt surface, the glass pool was bubbled until the dip samples indicated that the sulfate layer had dissipated prior to commencing the subsequent test segment.

\subsection{DM10 System Description}

\subsubsection{Feed System}

The feed container is mounted on a load cell for weight monitoring and is stirred continuously except for periodic, momentary interruptions during which the weight is recorded. The material in the feed container is constantly recirculated, which provides additional mixing. The recirculation loop extends to the top of the melter where feed is diverted from the recirculation loop through a peristaltic pump into the melter through a Teflon-lined feed line and vertical water-cooled feed tube. A diverter valve permits direction of the feed stream either to the melter or to a sampling vessel.

\subsubsection{Melter}

The DM10 system used for this work is a ceramic refractory lined melter, which includes two Inconel 690 plate electrodes that are used for joule-heating of the glass pool and a bubbler for agitating the melt. Glass is discharged from the melter using an air-lift system. The melt pool has a surface area of $0.021 \mathrm{~m}^{2}$ and typically contains about $8 \mathrm{~kg}$ of glass. The plenum volume is 19.5 liters at the nominal glass level. Inconel 690 thermowells were custom fabricated and installed in the DM10 for the current tests since in previous tests, thermowells made from Inconel 601 experienced rapid corrosion [5]. 
The Catholic University of America

Vitreous State Laboratory
Enhanced LAW Glass Formulation Testing

Final Report, VSL-07R1130-1, Rev. 0

\subsubsection{Off-Gas System}

For operational simplicity, the DM10 is equipped with a dry off-gas treatment system involving gas filtration operations only. Exhaust gases leave the melter plenum through a film cooler device that minimizes the formation of solid deposits. The film cooler air has constant flow rate and its temperature is thermostatically controlled. The geometry of the transition line (between the melter and the first filtration device) conforms to the requirements of the 40-CFR-60 air sampling techniques. Immediately downstream of the transition line are cyclonic filters followed by conventional pre-filters and HEPA filters. The temperature of the cyclonic filters is maintained above $150^{\circ} \mathrm{C}$ while the HEPAs are held above $100^{\circ} \mathrm{C}$ to prevent moisture condensation. The entire train of gas filtration operations is duplicated and each train is used alternately. An induced draft fan completes the system. The sampling location for gaseous species monitored by FTIR is immediately downstream of the draft fan.

\subsection{DM10 Test Conditions}

Target processing conditions, including bubbling rate adjusted to maintain the target production rate of $2250 \mathrm{~kg} / \mathrm{m}^{2} /$ day, a melt pool temperature of $1150^{\circ} \mathrm{C}$, and a complete cold cap were achieved throughout the majority of the melter tests. The main challenge to achieving these conditions was foaming of the glass during Tests 2,3 , and 4 . The foaming coincided with the use of tin and vanadium as additives at oxide concentrations greater than one and half weight percent. It is also worth noting that foaming occurred while processing glass compositions with relatively high viscosities. Since foaming is a result of gas evolution in the glass combined with the inability of the gas bubbles to rise and dissipate, there is probably a combination of contributing factors such as the concentrations of redox species in the glass, glass melt temperature, glass melt viscosity, glass redox state, etc. Average test segment production rates were within $10 \%$ of the target rate except for test segments with extensive foaming, which required feed interruptions to allow foam to dissipate or reduced feed rates. Test segment average bubbling rates ranged from 1.8 to 6.5 liters per minute and were significantly lower while processing the AZ-101/Sub-Envelope B1 (Region E) simulant in Test 1 . The measured test segment average glass temperatures two inches from the melt pool floor were between 1148 $1153^{\circ} \mathrm{C}$ for all but two of the test segments, thus indicating that the target glass temperature of $1150^{\circ} \mathrm{C}$ was achieved. During these two segments, test segment average temperatures were $20^{\circ} \mathrm{C}$ lower due to the high conductivity of the glass (in combination with the high glass production rate and foam), which limited the amount of power that could be used with this particular melter system. Measured glass temperatures two inches higher in the glass pool were 5 to $40^{\circ} \mathrm{C}$ lower throughout testing due to the proximity to the glass surface. Each test segment started with the melt pool at the nominal operating temperature of $1150^{\circ} \mathrm{C}$. A typical plot of DM10 melter temperatures is given in Figure 3.1. The plot is from the first conducted test segment (Region E, Test 1A) and a portion of the idling time prior to Test 1B. As mentioned above, the data at 2" from the melter bottom are most representative of the bulk glass temperature; these data average very close to the target of $1150 \mathrm{C}$ and vary little over the course of the test. The measurement 4" from the bottom is closer to the melt surface and varies by about $80^{\circ} \mathrm{C}$ as the level of the class changes. In keeping with previous DM10 tests, the electrode 
The Catholic University of America

Vitreous State Laboratory
Enhanced LAW Glass Formulation Testing

Final Report, VSL-07R1130-1, Rev. 0

temperatures were 50 to $100^{\circ} \mathrm{C}$ lower than the highest glass pool temperatures. The measured test segment average plenum temperatures were well below $600^{\circ} \mathrm{C}$, indicating that a complete cold cap covered the melt pool surface throughout the tests. A typical plot of DM10 plenum temperatures is given in Figure 3.2. Unlike plenum temperature measurements on larger melters, the exposed thermocouple often gave a lower temperature reading than the thermocouple in the thermowell due to variable amounts of feed coating the exposed thermocouple.

\subsection{DM10 Test Results}

Evaluation of glass pool samples provided a clear indication of the tolerance of the glass formulations to sulfur at nominal melter conditions. The only exception is the AN-105 Region A formulation ORPLA15, where feeds with twice the maximum target $\mathrm{SO}_{3}$ concentration of $0.3 \mathrm{wt} \%$ were processed without the formation of secondary sulfate phases; cost and schedule constraints did not permit the addition of yet more test segments to determine the upper limit for this formulation. Depictions of the target and measured sulfur contents are provided in Figure 3.3 for all five test series. During the initial test series with Region E (AZ-101) feeds, it was discerned from preliminary XRF measurements of product glass that the chromium concentration far exceeded the target concentration due to leaching of chromium from melter bricks and Inconel components. Recent melter test with LAW simulants have shown that high chromium concentration facilitate the formation of secondary sulfate phases that would not form otherwise [52]. In response to this, the chromium concentration in the feed was reduced after the second test segment (1B) to compensate for the expected chromium input from corrosion. As expected, the secondary phases that were observed while processing feed targeting Region $\mathrm{E}$ (AZ-101) wastes with $1.5 \mathrm{wt} \% \mathrm{SO}_{3}$ at elevated chromium concentrations were not observed at target chromium concentrations. Subsequent tests with sulfur at higher concentrations resulted in secondary sulfur phases despite the adjustment of the feed chromium content. Five test segments with the Region A (AN-105) waste and increasing sulfur content demonstrated a doubling of sulfur content from the target maximum, a doubling of sulfur content from the crucible batch saturation tests (see Section 2.1.2), and the need to perform additional tests at yet higher feed sulfur concentrations. Sulfur feed and glass concentrations continued to increase during tests with Region B (AN-107) waste; secondary sulfur phases were observed at $1 \mathrm{wt} \% \mathrm{SO}_{3}$ and therefore saturation occurred between 0.85 and $1 \mathrm{wt} \% \mathrm{SO}_{3}$ targeted in the feed. Subsequent tests with the Region $\mathrm{C}$ (AN-104) waste resulted in a decrease in feed sulfur contents to $0.7 \mathrm{wt} \% \mathrm{SO}_{3}$ in order to prevent the formation of a secondary sulfur phase. The most extensive secondary phases were observed during tests with this waste stream, which required short intervals of feeding sulfur-free feed to insure unbiased results in subsequent test segments. The sulfur concentration was increased in the test series with Region D (AN-102) waste, reaching a feed concentration of $1.1 \mathrm{wt} \% \mathrm{SO}_{3}$ without the formation of secondary sulfur phases, while tests at $1.3 \mathrm{wt} \% \mathrm{SO}_{3}$ did show secondary sulfur phases. 
The Catholic University of America

Vitreous State Laboratory
Enhanced LAW Glass Formulation Testing Final Report, VSL-07R1130-1, Rev. 0

\subsection{Gases Monitored by FTIR}

Melter emissions were monitored in each test for a variety of gaseous components, most notably carbon monoxide, ammonia, sulfur dioxide and nitrogen species, by Fourier Transform Infra Red Spectroscopy (FTIR). The off-gas system temperature is maintained well above $100^{\circ} \mathrm{C}$ beyond the sampling port downstream of the HEPA filter in order to prevent analyte loss due to condensation prior to monitoring. Test segment average concentrations of $\mathrm{NO}, \mathrm{NO}_{2}, \mathrm{CO}$, and $\mathrm{NH}_{3}$ are provided in Tables 3.1-3.5; these analytes are those that were expected to be observed during the test, based on previous work. No $\mathrm{SO}_{2}$ was detected in any of the tests and therefore none is reported in the tabular data. The FTIR detection limit for sulfur dioxide is relatively high (5 ppmv) and, therefore, measurable quantities are only observed with high sulfur containing feeds and in systems with minimal dilution of the melter exhaust by film cooler or process air. The most abundant nitrogen species monitored was NO, which is consistent with previous tests $[2-4,5,6,9,10,15-24,49,50,52]$ in which nitrates and nitrites were abundant in the feed. The

measured concentrations of most monitored components increase with increasing feed nitrogen oxide content and feed rates. Nitrogen oxide, carbon monoxide, and ammonia concentrations are higher in tests with the feed containing the Region A (AN-105), C (AN-104), and D (AN-102) simulants as a result of the higher nitrate and, therefore, organic content in the feed. 
The Catholic University of America

Vitreous State Laboratory
Enhanced LAW Glass Formulation Testing

Final Report, VSL-07R1130-1, Rev. 0

\section{SECTION 4.0 DM10 GLASS PRODUCTS}

Over half a metric ton of glass was produced in these tests. The glass was discharged from the melter periodically into square steel cans using an airlift system. The discharged product glass was sampled at the end of each test by removing sufficient glass from the top of the cans for total inorganic analysis. Care was exercised during sampling of each can to identify and segregate any secondary phases that were observed. Secondary phases in the discharged glass were only observed in test segments from Test 4, which also had secondary sulfur phases on the glass pool dip samples. These secondary phases are shown in Figure 4.1. Much of the discharged glass from Tests $2-4$ was foamy and, therefore, appeared somewhat translucent in appearance. Additional samples were taken from the end of each test and sealed in containers for shipment to ORP, as required by the Test Plan [37]. Product glass masses, discharge date, and analysis performed are listed in Table 4.1. Glass samples were also obtained by dipping a rod into the glass pool at the beginning and end of each test. These "dip samples" underwent visual examination to detect the presence of a separate sulfate phase on the glass pool surface.

\subsection{Compositional Analysis}

Glass discharge samples were crushed and analyzed directly by XRF. No visible secondary phases were included in the samples used for compositional analysis. The target values for boron and lithium oxides, which are not determined by XRF, were used for normalizing the XRF data to $100 \mathrm{wt} \%$. The XRF-analyzed compositions of all discharged glass samples are provided in Tables 4.2. XRF analysis of samples from the end of tests with the highest sulfur concentrations without forming secondary phases on the melt pool surface are compared with the target composition and results of DCP analysis of solutions generated by microwave aided acid dissolution in Tables 4.3 and 4.4, respectively. The majority of the XRF analysis results compare favorably to their corresponding target values and feed sample analysis (see Section 2.7.2). The concentrations of vanadium and tin oxides derived from additives were 11 to 22 relative percent above target concentrations. In all but one tin analysis, the concentrations measured by the DCP method were closer to target values, suggesting that the XRF may have a high bias for these elements. Above target concentrations of vanadium were also measured in previous tests $[2,6,51]$. Similar to the feed samples, zirconium oxide concentrations were up to fifteen relative percent below target concentrations, due presumably to chemical purity. Iron oxide concentrations were above the low target concentrations due to the ubiquity of the element in bulk chemicals. Elements not included in the target glass compositions, including iodine, manganese, neodymium, nickel, lead, titanium, and tin were observed in the product analysis as a result of corrosion of melter components, carry-over from previous tests, and trace contamination of additives. The lower than target concentration of sodium observed in the feed samples for Test 5 (see Section 2.7.2) is also observed in the glass product. Measured boron concentrations were within four percent of the target, validating the use of the target value for normalizing the XRF data. Agreement between the two analytical methods was excellent, except for low sodium values obtained from the DCP analysis, which is due in 
The Catholic University of America Vitreous State Laboratory
Enhanced LAW Glass Formulation Testing Final Report, VSL-07R1130-1, Rev. 0

part to a low-bias for sodium [6,51]; previous experience indicates that the XRF results are more reliable in this regard.

Compositional trends of the major and select oxides during the tests are shown in Figures 4.2 - 4.13. They illustrate the differences between the tested compositions and closeness to target over the course of the tests. These depictions also show the sampling and analytical variations attributable to the methods used; for example, calcium shows minimal variability whereas zirconia can vary by about 1 weight percent in sequential glass discharges. Scatter in the data for some elements were also observed at the beginning of the second test. Unlike the last four tests, which were conducted within a short amount of time, the first test was conducted five months earlier with other glass compositions not associated with the current study being processed during the intervening interval. This discontinuity is readily observed in the changes in silicon, calcium, zirconium, and potassium between 125 and $150 \mathrm{~kg}$ glass production. The glass compositions tested derive all the alkali metals, halides, sulfur, and almost none to half of the aluminum from the waste. The changes in additive concentrations shown in Figures $4.4-4.9$ reflect the manipulation of glass forming additives to achieve the desired glass properties. The deviations described above for vanadium, tin, zirconium, and silicon (last test sequence only) are evident in the plotted data. As intended, sodium spanned a range of about ten percent oxide, which was greater than for any other element. The plotted sodium data show considerable scatter but a close approximation to target for four of the compositions. The measured cesium concentrations show an even greater amount of relative scatter, whereas measured potassium concentrations showed little deviation during steady state processing. The potassium plot also shows a frequently observed trend of measured concentrations being above target for very low target values of very common elements due to trace contamination of feed [51]. The cesium data suggest, despite the noise in the data, that cesium is more volatile at the higher alkali concentrations in Tests 2 and 3, in agreement with previous observations [53]. Also supporting previous observations of volatility is the near $50 \%$ loss of chlorine from the glass at target concentrations greater than 0.3 weight percent [24, 52]. Another previously documented volatility trend $[5,6,9,10,24,52]$ implied by the data is the higher degree of sulfur retention in compositions with higher glass sodium concentrations (see Figure 3.3). Complete sampling and analysis of melter exhaust commonly conducted on larger melters [2-6, 9, 10, 15-24, 49, 50, 52, 53 ] is required for a more accurate assessment of elemental volatility and mass balance calculations. Measured chromium oxide concentrations were about 0.25 weight percent above target concentrations until adjustments were made to the feed to account for melter brick and Inconel component corrosion. Subsequent to this modification at about $50 \mathrm{~kg}$ glass production, chromium values more closely approximated the target, although chromium concentrations varied in response to idling periods, the formation of secondary sulfur phases, and the differences in corrosion rate for each composition.

\subsection{Secondary Phase Observations}

All discharged glass and glass “dip" samples taken directly from the melt pool were closely examined to document the presence or absence of secondary phases. Glass dip samples were obtained from three separate locations in the melt pool at the end of each test to ascertain 
The Catholic University of America

Vitreous State Laboratory
Enhanced LAW Glass Formulation Testing Final Report, VSL-07R1130-1, Rev. 0

whether a secondary sulfate layer had formed on the surface of the glass melt in response to each feed sulfur concentration during each test segment. Samples were also taken to ensure the melt surface was free of secondary phases prior to starting each test segment, as well as after bubbling intended to volatilize sulfur from a previously formed sulfur layer. Table 4.5 provides a listing of all of the dip samples and whether or not a separate salt phase was evident. Examples of secondary phases observed while processing three of the formulations are shown in Figures 4.14 -4.16 . Notice the powdery yellow material adhering to the rod and interspersed throughout some of the glass, both of which are indicative of a sample taken from a melt pool with a sulfate layer on the surface. Some of the sulfur layers that formed on the glass pool surface were extensive. Several hours of melt pool bubbling, and in some instances water feeding, were required to rid the melt pool of secondary phases.

\subsection{Comparison of PCT and VHT of Crucible and Melter Glasses}

Samples of DM10 discharge glasses from each of Regions A, B, C, D and E melter tests were subjected to the PCT. Samples were collected from test segments during which the highest sulfate concentrations that did not result in secondary sulfate phases were processed. The PCT releases of the melter glasses, along with those of crucible glasses with the same target compositions, are given in Table 4.6. PCT releases of all of the melter and crucible glasses are well below the WTP contract limit mass loss of $2.0 \mathrm{~g} / \mathrm{m}^{2}$ for B, Na and Si. The PCT release of Regions A, B, C and E melter and crucible glasses are similar, with the differences within expected variations based on round robin PCT testing of an Argonne National Laboratory-Low Activity Reference Material (ANL-LRM) glass sample [54]. The PCT releases of the Region D crucible glass ORPLD1 and the melter glass of the same target composition T10-G-16A are different, with the melter glass showing PCT releases of about half that of the crucible glass. This is due to the lower than target $\mathrm{Na}_{2} \mathrm{O}$ concentration measured in the melter glass (see Sections 2.7.2 and 4.1). Previous PCT testing [11-14, 48] has shown that PCT releases of glasses with similar compositions increase as the alkali content of the glass is increased.

VHT results for the melter and corresponding crucible glasses with the same target composition are given in Table 4.7. VHT alteration rates calculated by two different methods are given in Table 4.7. One method involves direct measurement of the alteration layer thickness, while the other involves measurement of the remaining glass. The VSL Standard Operating Procedure (SOP) for VHT measurement specifies that when the alteration layer thickness is greater than $100 \mu \mathrm{m}$, it should be determined based on the remaining glass. This is because when the alteration layer thickness is sufficiently large, measuring the dimensions of the remaining glass and subtracting it from the original sample dimensions gives a better estimate of the thickness of the altered glass. A direct measurement of the layer thickness can provide erroneous values because the altered layer may have expanded, thus giving a larger value than the actual thickness of the altered part of the glass sample, particularly for thick layers. The VHT alteration rates given in Section 2 are mostly based on the measurement of the remaining glass.

The VHT alteration rates for the Region E crucible and melter glasses given in Table 4.7 show good agreement with each other. The VHT alteration rate measurements based on layer 
The Catholic University of America Vitreous State Laboratory
Enhanced LAW Glass Formulation Testing Final Report, VSL-07R1130-1, Rev. 0

thickness and remaining glass also are in agreement for these glasses. The VHT results for the Region D melter and crucible glasses given in Table 4.7 show very good agreement with each other. The alteration rates based on layer thickness and remaining glass also show reasonable agreement with the alteration rates based on remaining glass showing somewhat lower values than those based on layer thickness.

The alteration rates for the Region A crucible glass ORPLA15 based on layer thickness and remaining glass show good agreement. For two of the three melter glasses, the alteration rates based on layer thickness agree with the results from the crucible glass; however, the alteration rates based on the remaining glass are substantially higher and above the contract limit of $50 \mathrm{~g} / \mathrm{m}^{2} /$ day. Since the measured compositions of the crucible and melter glasses show good agreement with the target and with each other, the origin of these differences is of interest. Figure 4.17 shows SEM images of cross sections of coupons of the Region A glass after VHT; Figure 4.17a shows the VHT coupon of the crucible glass and 4.17b shows the coupon of the melter glass. Unlike the crucible glass, the melter glass contains a number of fractures and extensive alteration of the glass is evident around these fractures. The higher measured VHT alteration rates for the melter glass are mainly due to the presence of these fractures (as well as some bubbles that are not shown). The fractures are more common in high alkali glasses, and especially in high alkali melter glasses. These could be micro cracks that exist in the glass sample or cracks that form from imperfections such as bubbles or small secondary phases. In any case, the occurrence of these cracks substantially increases the VHT alteration rates of high alkali glasses. Since the extent of cracking was much more in the melter glasses, in some cases their VHT alteration rates are above the contract limit even though the VHT for the corresponding crucible glass falls below that limit. From earlier work [5, 6, 48] it was already clear that increasingly large variations in VHT alteration rates can be expected for high $\mathrm{Na}_{2} \mathrm{O}$ ( $>23 \mathrm{wt} \%$ ) glasses and, therefore, for these glasses the measurements were done in duplicate. This large inherent variability in the VHT response coupled with the VHT alteration rate enhancement due to cracking suggests that relaxation of the VHT criterion may be necessary if $\mathrm{Na}_{2} \mathrm{O}$ loadings higher than about 23-24 wt\% are desired.

VHT alteration rates for the Region B crucible and melter glasses also show behavior similar to that of Region A glasses. The alteration rates for the crucible glass based on layer thickness and remaining glass and for the melter glass based on layer thickness are in agreement with each other. The alteration rates for the Region B melter glass based on remaining glass are higher, and above the contract limit of $50 \mathrm{~g} / \mathrm{m}^{2} /$ day. SEM micrographs of cross sections of the VHT coupons given in Figure 4.18 show that the crucible glass has no bubbles and less fractures compared to the melter glass. Again, measured VHT alteration rates increase substantially when the VHT coupon has more fractures.

VHT alteration rates for the Region $\mathrm{C}$ glasses show good agreement between the crucible and melter glasses, as well as between measurements based on layer thickness and remaining glass. SEM micrographs of cross sections of the VHT coupons given in Figure 4.19 show that the crucible and melter glasses are similar in that the melter glass sample does not have too many fractures and that the there is little alteration near the bubbles in the melter glass. 
The Catholic University of America

Vitreous State Laboratory
Enhanced LAW Glass Formulation Testing

Final Report, VSL-07R1130-1, Rev. 0

\section{SECTION 5.0 SUMMARY AND CONCLUSIONS}

Several tests were conducted on the DM10 vitrification system to evaluate newly developed LAW glass formulations intended to maximize sodium content while incorporating high levels of sulfur without the formation of secondary salt phases. Glass formulations selected for the melter tests were developed on the basis of a series of crucible melts that were prepared and characterized. Glasses were formulated for five different waste streams, maximizing sodium content at progressively higher target sulfur contents while meeting requirements for product quality (PCT and VHT), refractory corrosion characteristics, and processing properties. Glass former additives that were beneficial in reducing VHT alteration rate include $\mathrm{ZrO}_{2}$ and $\mathrm{SnO}_{2}$. $\mathrm{Cr}_{2} \mathrm{O}_{3}$ was beneficial in reducing $\mathrm{K}-3$ corrosion, whereas $\mathrm{CaO}, \mathrm{Li}_{2} \mathrm{O}$, and $\mathrm{V}_{2} \mathrm{O}_{5}$ additions improved sulfur solubility in the glass. However, the effect of the addition of each of these components cannot be taken in isolation. They have to be considered in combination with the other glass former additives, the overall composition of the glass, and relevant glass melt properties such as viscosity and glass redox state. Each glass formulation was processed on the DM10 with progressively more sulfur until a secondary sulfur phase formed, in order to determine the maximum feed sulfur concentration that could be processed. Glasses from each formulation with the highest sulfur content that did not form secondary sulfur phases were fully analyzed for comparison to the results obtained on the corresponding crucible glasses.

The GFC additives that are used in the LAW glasses are $\mathrm{Al}_{2} \mathrm{O}_{3}, \mathrm{~B}_{2} \mathrm{O}_{3}, \mathrm{CaO}, \mathrm{Cr}_{2} \mathrm{O}_{3}$, $\mathrm{Fe}_{2} \mathrm{O}_{3}, \mathrm{Li}_{2} \mathrm{O}, \mathrm{MgO}, \mathrm{SiO}_{2}, \mathrm{SnO}_{2}, \mathrm{~V}_{2} \mathrm{O}_{5}, \mathrm{ZnO}$ and $\mathrm{ZrO}_{2}$. $\mathrm{ZnO}$ is added at concentrations in the range of 2 to $3 \mathrm{wt} \%$ mainly to reduce corrosion of $\mathrm{K}-3$ refractory by the glass. It is also beneficial in reducing corrosion of Inconel components. $\mathrm{MgO}$ and $\mathrm{Fe}_{2} \mathrm{O}_{3}$ are added at concentrations of about $1 \mathrm{wt} \%$ to reduce K-3 corrosion and as an allowance for their presence as impurities in other GFCs. In general, components such as $\mathrm{Al}_{2} \mathrm{O}_{3}, \mathrm{SiO}_{2}, \mathrm{SnO}_{2}$, and $\mathrm{ZrO}_{2}$ improve the chemical durability of the glass including performance on PCT and VHT. Of these $\mathrm{ZrO}_{2}$ and $\mathrm{SnO}_{2}$ are the most effective in reducing VHT alteration rates. These components usually are also effective in reducing corrosion of both K-3 and Inconel by the glass. Increases in $\mathrm{B}_{2} \mathrm{O}_{3}$ concentration can have variable effects on chemical durability and typically tend to reduce melt viscosity. $\mathrm{Cr}_{2} \mathrm{O}_{3}$ is added solely to reduce corrosion of $\mathrm{K}-3$ refractory by the glass. $\mathrm{Li}_{2} \mathrm{O}, \mathrm{CaO}$ and $\mathrm{V}_{2} \mathrm{O}_{5}$ all are beneficial in increasing sulfate loading in the feed with $\mathrm{Li}_{2} \mathrm{O}$ being most effective. In general, as very high sodium glasses are formulated the concentration of components that reduce corrosion and improve chemical durability need to be increased. In addition, these components usually increase the viscosity of the glass melt. As relatively lower sodium and higher sulfate glasses are formulated, the concentrations of additives that increase sulfate solubility are increased.

VSL and EnergySolutions have previously developed and tested a number of LAW glass formulations for ORP [4-6] and WTP [11-14]. The WTP formulations were tested at the crucible scale and at various melter scales including the one-third scale LAW Pilot Melter at 
The Catholic University of America Vitreous State Laboratory
Enhanced LAW Glass Formulation Testing Final Report, VSL-07R1130-1, Rev. 0

EnergySolutions. As a result of the considerable testing completed with the WTP formulations, there is high confidence that they can be used to process LAW at Hanford with little additional testing. The recommended glass compositions for waste processing were selected such that they can tolerate process variations without adverse effects on processing or product quality. Based on these well-tested formulations, VSL developed a LAW glass formulation correlation that is currently being used by the WTP [55]. Compositions produced by this correlation fall along the dotted lines in Figure 5.1. The WTP formulations were developed to comply with the requirements of the Bechtel contract with ORP [46]. Although these formulations are fully compliant, extensive further optimization with respect to waste loading could not be performed due to the schedule constraints imposed by the LAW Pilot Melter testing program defined by the WTP Project. As a result, while this extensive basis set of formulations provides a solid underpinning of the WTP baseline, there is also potential for improvement of waste loadings. Exploiting this potential has been the subject of the present and previous work for ORP.

LAW testing for ORP at VSL and EnergySolutions was aimed at optimizing the glass formulations and processing parameters in order to minimize the volume of glass produced and to shorten the plant operating schedule. Since the major waste loading limiting constituents in Hanford LAW are sodium and sulfur, glass formulation development and testing were focused on maximizing the incorporation of these components in the glass. Earlier testing for ORP targeted glass formulations at about 20-23 wt\% $\mathrm{Na}_{2} \mathrm{O}$ and highest achievable $\mathrm{SO}_{3}$ [2, 5, 6], and $10 \mathrm{wt} \% \mathrm{Na}_{2} \mathrm{O}$ and highest achievable $\mathrm{SO}_{3}$ [6]. The LAW glass formulations developed from those tests, LAWA187, LAWA161, LAWC100, and LAWB99, are shown in Figure 5.1; target and measured $\mathrm{Na}_{2} \mathrm{O}$ and $\mathrm{SO}_{3}$ concentrations in current and previous ORP LAW glasses are given in Table 5.1. As is evident from Figure 5.1, these glasses represent considerable increases in waste loadings over the WTP baseline and therefore considerable potential for reductions in cost and schedule. The principle objective of the present work was to assess the likely limits to the extent of this improvement over the relevant range of sodium and sulfur content by formulating and testing bounding glasses. Five high waste loading glass formulations spanning the range of expected $\mathrm{Na}_{2} \mathrm{O}$ and $\mathrm{SO}_{3}$ concentrations in the $\mathrm{LAW}$ glasses were developed and subjected to melter testing. Glass formulation development and testing were designed such that the maximum achievable waste loadings could be determined. This required that the testing focus on those properties of the high waste loading glasses that are most challenging with respect to processing or product quality. For the high $\mathrm{Na}_{2} \mathrm{O}$ glasses, the most challenging property was VHT alteration rate. Therefore, glasses were designed to have VHT alteration rates near the contract limit of $50 \mathrm{~g} / \mathrm{m}^{2} /$ day and, in fact, by design, many of the candidate glasses exceeded this limit. Glasses for melter testing also were selected with the intent of determining the limits of achievable waste loadings. The LAW glasses selected for the current set of melter tests for the five regions (ORPLA15, ORPLB4, ORPLC5, ORPLD1 and ORPLE12) are also shown in Figure 5.1. As is evident from the figure, the current ORP glasses have much higher waste loadings than the WTP glasses, and higher combined $\mathrm{Na}_{2} \mathrm{O}$ and $\mathrm{SO}_{3}$ loadings than previous ORP glasses, with the exception of LAWA187, which falls on the trend line defined by the results for the current glasses $^{1 .}$

\footnotetext{
${ }^{1}$ It is recognized that the melter test for the Region D glass was somewhat lower in sodium than targeted. While it would therefore be useful to repeat this test, this is unlikely to significantly affect the trend line shown in Figure 5.1.
} 
The Catholic University of America

Vitreous State Laboratory
Enhanced LAW Glass Formulation Testing

Final Report, VSL-07R1130-1, Rev. 0

At the very high $\mathrm{Na}_{2} \mathrm{O}$ loadings (23 wt $\%$ or higher), VHT becomes especially challenging due to the rapid increase of VHT alteration rate with increasing alkali content, the increased variability in VHT response at high alkali content, and increased VHT alteration rates due to cracking in melter glasses. Relaxation of the VHT alteration rate limit may be necessary if higher $\mathrm{Na}_{2} \mathrm{O}$ glasses are desired. At the low sodium end, a glass formulation, ORPLE12, with 16 wt\% $\mathrm{Na}_{2} \mathrm{O}$ that can accommodate $1.5 \mathrm{wt} \% \mathrm{SO}_{3}$ was identified. This was the same $\mathrm{SO}_{3}$ loading limit that was observed in LAWB99 with $10 \mathrm{wt} \% \mathrm{Na}_{2} \mathrm{O}$ at a nominal melter operating temperature of $1150^{\circ} \mathrm{C}$. Achieving significantly higher $\mathrm{SO}_{3}$ loadings in borosilicate glasses would appear to be unlikely without changing the processing conditions or the processing and/or product quality constraints (it is a simple matter to achieve higher $\mathrm{SO}_{3}$ loadings by increasing the contents of $\mathrm{Li}$, $\mathrm{Ca}, \mathrm{V}$, etc., but such glasses do not meet VHT and refractory corrosion requirements). Thus, the glasses identified during the current work serve to define the likely limits of possible $\mathrm{Na}_{2} \mathrm{O}$ and $\mathrm{SO}_{3}$ loadings in Hanford LAW glasses that are compliant with the current product quality and processing requirements. It should be noted, however, that these glasses were tested only at the crucible and DM10 melter scales. Additional testing at larger scales is required to confirm the results from smaller scale testing and the results of such testing may result in refinement of these limits. It should also be noted that because of the bounding nature of the formulations (they are deliberately close to the limits of the requirements), practically viable operating points would fall at somewhat lower waste loadings since nominal glass compositions selected for waste processing need to accommodate process variations without adverse effects on processing or product quality. In addition, the corrosion rate of Inconel in these new glass compositions has not been tested. While experience suggests that the adjustments made to the glass compositions to reduce VHT alteration rate and K-3 corrosion, along with the higher viscosity, will also maintain acceptable Inconel corrosion rates, this needs to be confirmed through testing..

The LAW correlation was developed for the WTP by VSL/EnergySolutions to determine the types and amounts of glass forming chemicals (GFCs) to be used at the WTP for LAW processing under the current WTP baseline. This was possible only after the completion of much more extensive testing than has been done for the new ORP glasses and after a set of nominal Sub-Envelope formulations were refined. The data collected so far for the ORP higher waste loading glasses is not sufficient to attempt a revised LAW correlation algorithm, but does serve to define what types of waste loadings might be possible. Once the glass compositions are refined, GFC additives are defined, and suitable scale-up testing is completed, a new LAW formulation correlation, similar to the one currently being used by the WTP, would be developed to support the implementation of these higher waste loading glass compositions at the WTP in order to realize the cost and schedule reductions. 


\section{SECTION 6.0 \\ REFERENCES}

[1] LAW Pilot Melter Decommissioning and Testing, Letter Subcontract \#DE-AC2703RV14539.

[2] "Glass Formulation Testing to Increase Sulfate Incorporation,” K. S. Matlack, M. Chaudhuri, H. Gan, I. S. Muller, W. Gong, and I. L. Pegg, Final Report, VSL-04R49601, Rev. 0, Vitreous State Laboratory, The Catholic University of America, Washington, DC, 2/28/05.

[3] "Small Scale Melter Testing with LAW Simulants to Assess the Impact of Higher Temperature Melter Operations,” K.S. Matlack, W. Gong, and I.L. Pegg, Final Report, VSL-04R4980-1, Rev. 0, Vitreous State Laboratory, The Catholic University of America, Washington, DC, 2/13/04.

[4] "Glass Formulation Testing to Increase Sulfate Volatilization from Melter," K.S. Matlack, W. Gong, and I.L. Pegg, Final Report, VSL-04R4970-1, Rev. 0, Vitreous State Laboratory, The Catholic University of America, Washington, DC, 2/24/05.

[5] "LAW Envelope C Glass Formulation Testing to Increase Waste Loading," K.S. Matlack, W. Gong, I.S. Muller, I. Joseph, and I.L. Pegg, Final Report, VSL-05R5900-1, Rev. 0, Vitreous State Laboratory, The Catholic University of America, Washington, DC, $1 / 27 / 06$.

[6] "LAW Envelope A and B Glass Formulation Testing to Increase Waste Loading,” K.S. Matlack, H. Gan, I.S. Muller, I. Joseph, and I.L. Pegg, Final Report, VSL-06R6900-1, Rev. 0, Vitreous State Laboratory, The Catholic University of America, Washington, DC, 3/23/06.

[7] "Summary of Preliminary Results on Enhanced Sulfate Incorporation During Vitrification of LAW Feeds”, I.L. Pegg, H. Gan, I.S. Muller, D.A. McKeown, and K.S. Matlack, VSL-00R3630-1, Vitreous State Laboratory, The Catholic University of America, Washington, DC, 4/5/00.

[8] "Sulfur Incorporation in Waste Glass Melts of Various Compositions," W.K. Kot, H. Gan, and I.L. Pegg, Ceramic Transactions, Vol. 107, pp. 441, Eds. G.T. Chandler and X. Feng, American Ceramic Society, 2000.

[9] "Melter Tests with LAW Envelope B Simulants to Support Enhanced Sulfate Incorporation,” K.S. Matlack, S.P. Morgan, and I.L. Pegg, Final Report, VSL-00R35011, Rev. 0, Vitreous State Laboratory, The Catholic University of America, Washington, D.C., $11 / 27 / 00$. 
[10] "Melter Tests with LAW Envelope A and C Simulants to Support Enhanced Sulfate Incorporation,” K.S. Matlack, S.P. Morgan, and I.L. Pegg, Final Report, VSL-01R35012, Rev. 0, Vitreous State Laboratory, The Catholic University of America, Washington, D.C., $1 / 26 / 01$.

[11] “Glass Formulation and Testing with TWRS LAW Simulants,” Final Report, I.S. Muller and I.L. Pegg, Vitreous State Laboratory, The Catholic University of America, Washington, DC, 1/16/98.

[12] “Glass Formulation And Testing With RPP-WTP LAW Simulants,” I.S. Muller, A.C. Buechele, and I.L. Pegg, Final Report, VSL-01R3560-2, Vitreous State Laboratory, The Catholic University of America, Washington, DC, 2/23/01.

[13] “Baseline LAW Glass Formulation Testing,” I.S. Muller and I.L. Pegg, Final Report, VSL-03R3460-1, Rev. 0, Vitreous State Laboratory, The Catholic University of America, Washington, DC, 8/8/03.

[14] “Glass Formulations to Support Melter Testing”, I.S. Muller and I.L. Pegg, Final Report, VSL-03R3460-2, Rev. 0, Vitreous State Laboratory, The Catholic University of America, Washington, DC, 2/6/04.

[15] "Compositional Variation Tests on DuraMelter 100 with LAW Sub-Envelope A1 Feed (LAWA44 Glass) in Support of the LAW Pilot Melter,” K.S. Matlack, W. Gong, and I.L. Pegg, Final Report, VSL-02R62N0-4, Rev. 0, Vitreous State Laboratory, The Catholic University of America, Washington, D.C., 6/18/02.

[16] "Compositional Variation Tests on DuraMelter 100 with LAW Sub-Envelope A2 Feed (LAWA88) Glass in Support of the LAW Pilot Melter,” K. S. Matlack, W. Gong and I.L. Pegg, Final Report, VSL-02R62N0-3, Rev. 0, Vitreous State Laboratory, The Catholic University of America, Washington, D.C., 11/1/02.

[17] “Compositional Variation Tests on DuraMelter 100 with LAW Sub-Envelope A3 Feed in Support of the LAW Pilot Melter,” K.S. Matlack, W. Gong, and I.L. Pegg, Final Report, VSL-01R62N0-1, Rev. 1, Vitreous State Laboratory, The Catholic University of America, Washington, D.C., 7/15/02.

[18] "Compositional Variation Tests on DuraMelter 100 with LAW Sub-Envelope B1 Feed in Support of the LAW Pilot Melter,” K.S. Matlack, W. Gong, and I.L. Pegg, Final Report, VSL-02R62N0-5, Rev. 0, Vitreous State Laboratory, The Catholic University of America, Washington, D.C., 5/8/03.

[19] "Compositional Variation Tests on DuraMelter 100 with LAW Sub-Envelope B2 Feed in Support of the LAW Pilot Melter,” K.S. Matlack and I.L. Pegg, Final Report, VSL03R3410-2, Rev. 0, The Catholic University of America, Vitreous State Laboratory, Washington, D.C., 10/20/03. 
[20] “Compositional Variation Tests on DuraMelter 100 with LAW Sub-Envelope C1 Feed (LAWC22 Glass) in Support of the LAW Pilot Melter,” K.S. Matlack, W. Gong, and I.L. Pegg, Final Report, VSL-02R62N0-2, Rev. 1, Vitreous State Laboratory, The Catholic University of America, Washington, D.C., 9/23/02.

[21] “Compositional Variation Tests on DuraMelter 100 with LAW Sub-Envelope C2 Feed in Support of the LAW Pilot Melter," K.S. Matlack, W. Gong, R.A. Callow and I.L. Pegg, Final Report, VSL-04R4410-1, Rev. 0, Vitreous State Laboratory, The Catholic University of America, Washington, DC, 6/17/04.

[22] "DuraMelter 100 Sub-Envelope Changeover Testing Using LAW Sub-Envelope A1 and C1 Feeds in Support of the LAW Pilot Melter,” K.S. Matlack, W. Gong, and I.L. Pegg, Final Report, VSL-02R62N0-6, Rev. 0, Vitreous State Laboratory, The Catholic University of America, Washington, D.C., 9/9/03.

[23] "DuraMelter 100 Sub-Envelope Changeover Testing Using LAW Sub-Envelope A2 and B1 Feeds in Support of the LAW Pilot Melter,” K.S. Matlack, W. Gong, and I.L. Pegg, Final Report, VSL-03R3410-1, Rev. 0, Vitreous State Laboratory, The Catholic University of America, Washington, D.C., 8/22/03.

[24] "DuraMelter 100 Sub-Envelope Changeover Testing Using LAW Sub-Envelope A3 and C2 Feeds in Support of the LAW Pilot Melter,” K.S. Matlack, W. Gong, and I.L. Pegg, Final Report, VSL-03R3410-3, Rev. 0, Vitreous State Laboratory, The Catholic University of America, Washington, D.C., 10/17/03.

[25] “RPP-WTP Pilot Melter Envelope B Throughput Test Results Report,” TRR-PLT-57, Duratek, Inc., Columbia, MD, 10/13/00.

[26] “RPP-WTP Pilot Melter Envelope A and C Throughput Test Results Report,” TRR-PLT54, Duratek, Inc., Columbia, MD, 10/13/00.

[27] “RPP-WTP Pilot Melter Sub-Envelope A1 Variation Test Results Report,” TRR-PLT071, Rev. 0, Duratek, Inc., Columbia, MD, 4/28/03.

[28] “RPP-WTP Pilot Melter Sub-Envelope C1-A1 Changeover Test Results Report,” TRRPLT-035, Rev. 0, Duratek, Inc., Columbia, MD, 9/29/03.

[29] “RPP-WTP Pilot Melter Sub-Envelope A2 Variation Test Results Report," TRR-PLT070, Rev. 0, Duratek, Inc., Columbia, MD, 10/4/02.

[30] “RPP-WTP Pilot Melter Sub-Envelope A2-B1 Changeover Test Results Report,” TRRPLT-078, Rev. 0, Duratek, Inc., Columbia, MD, 11/3/03.

[31] “RPP-WTP Pilot Melter Sub-Envelope A3 Variation Test Results Report,” TRR-PLT060, Rev. 2, Duratek, Inc., Columbia, MD, 11/19/02. 
[32] “RPP-WTP Pilot Melter Sub-Envelope C2-A3 Changeover Test Results Report,” TRRPLT-079, Rev. 0, Duratek, Inc., Columbia, MD, 11/11/03.

[33] “RPP-WTP Pilot Melter Sub-Envelope B1 Variation Test Results Report,” TRR-PLT074, Rev. 0, Duratek, Inc., Columbia, MD, 8/26/03.

[34] “RPP-WTP Pilot Melter Sub-Envelope B2 Variation Test Results Report,” TRR-PLT073, Rev. 0, Duratek, Inc., Columbia, MD, 10/27/03.

[35] “RPP-WTP Pilot Melter Sub-Envelope C1 Variation Test Results Report,” TRR-PLT069, Rev. 2, Duratek, Inc., Columbia, MD, 2/6/03.

[36] “RPP-WTP Pilot Melter Sub-Envelope C2 Variation Test Results Report,” TRR-PLT072, Rev. 1, Duratek, Inc., Columbia, MD, 3/12/03.

[37] “Enhanced LAW Glass Formulation Testing,” K.S. Matlack, I.S. Muller, I. Joseph, and I.L. Pegg, Test Plan, VSL-06T1100-1, Rev. 0, Vitreous State Laboratory, The Catholic University of America, Washington, DC, 10/10/06.

[38] “Quality Assurance Project Plan for RPP-WTP Support Activities Conducted by VSL," Vitreous State Laboratory, QAPP Rev. 9, Vitreous State Laboratory, The Catholic University of America, Washington, DC, 6/5/07.

[39] “Master List of Controlled VSL Manuals and Standard Operating Procedures in Use,” QA-MLCP, Rev. 21, Vitreous State Laboratory, The Catholic University of America, Washington, DC, 7/23/07.

[40] "LAW Pilot Melter and DM-100 Sub-Envelope Changeover Testing," E.V. Morrey, WTP Test Specification, 24590-LAW-TSP-RT-02-012, Rev. 0.

[41] “Tank Farm Contractor Operation and Utilization Plan,” R.A. Kirkbride, et al., CH2M Hill Hanford Group Inc., Richland, WA, HNF-SD-SP-012, Rev. 3, 10/2/01.

[42] “Basis of Design,” BNFL report, DB-W375-EG00001, Rev. 0, November 23, 1998.

[43] "Physical and Rheological Properties of Waste Simulants and Melter Feeds for RPPWTP LAW Vitrification,” I.S. Muller, H. Gan, and I.L. Pegg, Final Report, VSL00R3520-1, Rev. 0, Vitreous State Laboratory, The Catholic University of America, Washington, DC, 1/16/01.

[44] “Characterization of Simulated WTP LAW Melter Feeds,” H. Zhao, I.S. Muller, and I.L. Pegg, Final Report, VSL-04R4500-1, Rev. 0, Vitreous State Laboratory, The Catholic University of America, Washington, DC, 5/26/04. 
[45] “Engineering Specification for Low Activity Waste Melters,” K. Clark, 24590-LAW-3PSAE00-T0001, River Protection Project - Waste Treatment Plant, Richland, WA, 2003

[46] U.S. Department of Energy, Office of River Protection, "Design, Construction, and Commissioning of the Hanford Tank Waste Treatment and Immobilization Plant," Contract Number: DE-AC27-01RV14136, 2001; and subsequent amendments.

[47] "Composition Effects on the Vapor Hydration of Waste Glasses," A.C. Buechele, F. Lofaj, I.S. Muller, C.T.F. Mooers, and I.L. Pegg, Ceramic Transactions, Vol. 155, p. 289, (2004).

[48] "Phase 1 ILAW PCT and VHT Model Development,” I.S. Muller, H. Gan and I.L. Pegg, VSL-04R4480-2, Rev. 0, Vitreous State Laboratory, The Catholic University of America, Washington, DC, Washington, D.C., 2/8/05.

[49] "Integrated Off-Gas System Tests on the DM1200 Melter with RPP-WTP LAW SubEnvelope A1 Simulants,” K.S. Matlack, W. Gong, T. Bardakci, N. D’Angelo, and I.L. Pegg, Final Report, VSL-02R8800-2, Rev. 0, Vitreous State Laboratory, The Catholic University of America, Washington, DC, 9/03/02.

[50] "Integrated Off-Gas System Tests on the DM1200 Melter with RPP-WTP LAW SubEnvelope C1 Simulants,” K.S. Matlack, W. Gong, T. Bardakci, D’Angelo, and I.L. Pegg, Final Report, VSL-02R8800-1, Rev. 0, Vitreous State Laboratory, The Catholic University of America, Washington, DC, 7/25/02.

[51] “Review of Properties of Simulated Feeds Used for Melter Testing," K.S. Matlack, W. Gong, and I.L. Pegg, Final Report, VSL-06R6410-1, Rev. 0, Vitreous State Laboratory, The Catholic University of America, Washington, DC, Washington, D.C., 8/16/06.

[52] “Small Scale Melter Testing of LAW Salt Phase Separation,” K.S. Matlack, I.S. Muller, W. Gong, and I.L. Pegg, VSL-07R7480-1, Rev. 0, Vitreous State Laboratory, The Catholic University of America, Washington, DC, 8/20/07.

[53] "Technetium/Cesium Volatility in DM100 Tests Using HLW AZ-102 and LAW SubEnvelope A1 Simulants,” Final Report, K.S. Matlack, W.K. Kot, and I.L. Pegg, VSL04R4710-1, Rev. 0, Vitreous State Laboratory, The Catholic University of America, Washington, D.C., 9/28/04.

[54] "Round Robin Testing of a Reference Glass for Low-Activity Waste Forms," W.L. Ebert and S.F. Wolf, Department of Energy report ANL-99/22, Argonne National Laboratory, Argonne, IL, 1999.

[55] "Proposed Approach for Development of LAW Glass Formulation Correlation”, I. S. Muller, G. Diener, I. Joseph and I. L. Pegg, VSL-03L4460-1, Rev. 2, Vitreous State Laboratory, The Catholic University of America, Washington, DC, 10/29/04. 
Table 1.1. Waste Compositions and Corresponding Target Concentrations in Glass.

\begin{tabular}{|c|c|c|c|}
\hline $\begin{array}{c}\text { Region } \\
\text { Designation }\end{array}$ & $\begin{array}{c}\text { Tank Waste/ } \\
\text { Sub-Envelope } \\
\text { Identification }\end{array}$ & $\begin{array}{c}\text { Target Minimum } \mathbf{N a}_{2} \mathbf{O} \\
\text { Concentration in Glass, } \\
\mathbf{w t} \%\end{array}$ & $\begin{array}{c}\text { Target Minimum } \mathbf{S O}_{3} \\
\text { Concentration in Glass, } \\
\mathbf{w t} \%\end{array}$ \\
\hline A & $\begin{array}{c}\text { AN-105/ } \\
\text { Sub-Envelope A1 }\end{array}$ & 25 & 0 \\
\hline B & $\begin{array}{c}\text { AN-107/ } \\
\text { Sub-Envelope C1 }\end{array}$ & 25 & 0.35 \\
\hline C & $\begin{array}{c}\text { AN-104/ } \\
\text { Sub-Envelope A3 }\end{array}$ & 25 & 0.65 \\
\hline D & $\begin{array}{c}\text { AN-102/ } \\
\text { Sub-Envelope C2 }\end{array}$ & 25 & 1.00 \\
\hline E & $\begin{array}{c}\text { AZ-101/ } \\
\text { Sub-Envelope B1 }\end{array}$ & 16 & 1.25 \\
\hline
\end{tabular}


Table 2.1. LAW Sub-Envelope A1 (AN-105) Waste Simulant Recipe at 8 Molar Sodium.

\begin{tabular}{|c|c|c|c|c|c|c|c|c|c|}
\hline $\begin{array}{c}\text { Envelope } \\
\text { Constituents }\end{array}$ & $\begin{array}{l}\text { Simular } \\
\text { including }\end{array}$ & $\begin{array}{l}\mathrm{J}-105 \\
\text { eatment }\end{array}$ & $\begin{array}{c}\text { Glass } \\
\text { Oxides }\end{array}$ & $\begin{array}{c}\mathrm{AN}-105 \\
\mathrm{Wt} \%\end{array}$ & $\begin{array}{l}\text { Source in } \\
\text { Simulant }\end{array}$ & $\begin{array}{l}\text { Order for } \\
\text { Addition }\end{array}$ & $\begin{array}{c}\text { Formula } \\
\text { Weight }\end{array}$ & Assay* & $\begin{array}{c}\text { Target } \\
\text { Weight (g) }\end{array}$ \\
\hline- & $\mathrm{mg} / \mathrm{L}$ & $\mathrm{M}$ & - & - & \multicolumn{5}{|c|}{ In $274.40 \mathrm{ml}$ water add following compounds in the order listed below } \\
\hline $\mathrm{Al}$ & 30554 & 1.132 & $\mathrm{Al}_{2} \mathrm{O}_{3}$ & 17.906 & $\begin{array}{c}\mathrm{Al}\left(\mathrm{NO}_{3}\right)_{3} \cdot 9 \mathrm{H}_{2} \mathrm{O}, 60 \% \text { sol. } \\
\mathrm{Al}\left(\mathrm{OH}_{3}\right.\end{array}$ & $\begin{array}{l}1 \\
8\end{array}$ & $\begin{array}{c}375.14 \\
78.00 \\
\end{array}$ & $\begin{array}{l}0.61 \\
1.00\end{array}$ & $\begin{array}{c}419.84 \\
35.50\end{array}$ \\
\hline $\mathrm{B}$ & 79 & 0.007 & $\mathrm{~B}_{2} \mathrm{O}_{3}$ & 0.078 & $\mathrm{H}_{3} \mathrm{BO}_{3}$ & 3 & 61.83 & 0.99 & 0.45 \\
\hline $\mathrm{Cr}$ & 149 & 0.003 & $\mathrm{Cr}_{2} \mathrm{O}_{3}$ & 0.067 & $\mathrm{Na}_{2} \mathrm{CrO}_{4} * 4 \mathrm{H}_{2} \mathrm{O}$ & 7 & 234.04 & 0.99 & 0.68 \\
\hline Cs (spike) & 1403 & 0.011 & $\mathrm{Cs}_{2} \mathrm{O}$ & 0.461 & $\mathrm{CsNO}_{3}$ & 2 & 194.91 & 1.00 & 2.06 \\
\hline $\mathrm{K}$ & 4608 & 0.118 & $\mathrm{~K}_{2} \mathrm{O}$ & 1.722 & $\mathrm{KOH}$ & 6 & 56.10 & 0.91 & 7.28 \\
\hline $\mathrm{Na}$ & 183920 & 8.000 & $\mathrm{Na}_{2} \mathrm{O}$ & 76.892 & $\mathrm{NaOH}, 50 \%$ sol. $d=1.53$ & 5 & 40.00 & 0.50 & 463.20 \\
\hline $\mathrm{Si}$ & 157 & 0.006 & $\mathrm{SiO}_{2}$ & 0.104 & $\mathrm{SiO}_{2}$ & 4 & 60.09 & 0.99 & 0.34 \\
\hline $\mathrm{Cl}$ & 6996 & 0.197 & $\mathrm{Cl}$ & 2.170 & $\mathrm{NaCl}$ & 9 & 58.45 & 0.99 & 11.65 \\
\hline $\mathrm{F}$ & 35 & 0.002 & $\mathrm{~F}$ & 0.011 & $\mathrm{NaF}$ & 10 & 42.00 & 0.99 & 0.08 \\
\hline $\mathrm{SO}_{4}$ (Nominal) & 2274 & 0.024 & $\mathrm{SO}_{3}$ & 0.588 & $\mathrm{Na}_{2} \mathrm{SO}_{4}$ (varied content per run) & 11 & 142.06 & 0.99 & See Table 2.10b \\
\hline $\mathrm{NO}_{2}$ & 85428 & 1.857 & - & - & $\mathrm{NaNO}_{2}$ & 15 & 69.00 & 0.97 & 128.79 \\
\hline $\mathrm{NO}_{3}$ & 126988 & 2.048 & - & - & $\mathrm{NaNO}_{3}$ & - & 84.99 & 0.99 & 0.00 \\
\hline TOC & 2093 & 0.174 & - & - & - & - & - & - & - \\
\hline Acetate & 2251 & 0.038 & - & - & Sodium Acetate (C2) & 12 & 136.08 & 0.99 & 5.24 \\
\hline Formate & 2135 & 0.047 & - & - & Sodium Formate (C1) & 13 & 68.01 & 0.99 & 3.26 \\
\hline Glycolate & 1936 & 0.025 & - & - & Glycolic Acid (C2) & 14 & 76.05 & 0.71 & 2.73 \\
\hline - & - & - & SUM & 100 & Tota & simulant wt & & & 1358.89 \\
\hline
\end{tabular}

- Empty data field.

* Assay refers to the purity of the raw material as specified by the vendor.

** Ratio provides the factor to convert the glass former additive into the corresponding oxide in the glass. 
Table 2.2. Target and Analyzed Compositions (wt\%) of Seventeen ORPLA Crucible Glasses.

\begin{tabular}{|c|c|c|c|c|c|c|c|c|c|c|c|c|}
\hline \multirow{2}{*}{$\begin{array}{l}\text { GLASS } \\
\text { Oxides }\end{array}$} & \multicolumn{2}{|c|}{ ORPLA1 } & \multicolumn{2}{|c|}{ ORPLA2 } & \multicolumn{2}{|c|}{ ORPLA3 } & \multicolumn{2}{|c|}{ ORPLA4 } & \multicolumn{2}{|c|}{ ORPLA5 } & \multicolumn{2}{|c|}{ ORPLA6 } \\
\hline & Target & Analyzed* & Target & Analyzed $^{*}$ & Target & Analyzed ${ }^{*}$ & Target & Analyzed* & Target & Analyzed ${ }^{*}$ & Target & Analyzed \\
\hline $\mathrm{Al}_{2} \mathrm{O}_{3}$ & 10.00 & 10.31 & 10.00 & 10.14 & 10.00 & 10.32 & 8.00 & 8.29 & 10.00 & 10.30 & 10.88 & 10.95 \\
\hline $\mathrm{B}_{2} \mathrm{O}_{3}$ & 9.00 & 9.26 & 9.00 & 9.57 & 9.00 & 9.31 & 9.00 & 9.36 & 7.00 & 6.81 & 7.78 & NA \\
\hline $\mathrm{CaO}$ & 3.50 & 3.66 & 2.50 & 2.62 & 3.04 & 3.13 & 3.50 & 3.57 & 1.00 & 1.08 & 1.00 & 1.10 \\
\hline $\mathrm{Cr}_{2} \mathrm{O}_{3}$ & 0.02 & 0.03 & 0.02 & 0.04 & 0.49 & 0.60 & 0.02 & 0.03 & 0.49 & 0.61 & 0.49 & 0.63 \\
\hline $\mathrm{Cs}_{2} \mathrm{O}$ (spike) & 0.19 & 0.16 & 0.19 & 0.19 & 0.19 & 0.21 & 0.19 & 0.20 & 0.19 & 0.21 & 0.19 & 0.17 \\
\hline $\mathrm{Fe}_{2} \mathrm{O}_{3}$ & 1.01 & 1.05 & 1.01 & 1.05 & 1.01 & 1.03 & 3.02 & 2.99 & 1.01 & 1.06 & 0.94 & 1.04 \\
\hline $\mathrm{K}_{2} \mathrm{O}$ & 0.56 & 0.63 & 0.56 & 0.63 & 0.56 & 0.60 & 0.56 & 0.61 & 0.56 & 0.59 & 0.56 & 0.60 \\
\hline $\mathrm{MgO}$ & 1.35 & 1.29 & 1.35 & 1.27 & 1.35 & 1.30 & 1.35 & 1.36 & 1.35 & 1.20 & 0.91 & 0.93 \\
\hline $\mathrm{Na}_{2} \mathrm{O}$ & 25.00 & 24.66 & 25.00 & 24.55 & 25.00 & 24.91 & 25.00 & 25.46 & 25.00 & 24.20 & 25.00 & 24.45 \\
\hline $\mathrm{SiO}_{2}$ & 41.31 & 41.48 & 41.31 & 41.36 & 41.31 & 40.98 & 41.31 & 40.41 & 43.31 & 43.16 & 41.92 & 41.61 \\
\hline $\mathrm{SnO}_{2}$ & 0.00 & 0.01 & 1.00 & 1.07 & 0.00 & 0.00 & 0.00 & 0.02 & 1.00 & 1.13 & 1.00 & 1.10 \\
\hline $\mathrm{TiO}_{2}$ & 0.00 & 0.04 & 0.00 & 0.03 & 0.00 & 0.04 & 0.00 & 0.03 & 0.00 & 0.03 & 0.00 & 0.04 \\
\hline $\mathrm{V}_{2} \mathrm{O}_{5}$ & 0.00 & 0.00 & 0.00 & 0.00 & 0.00 & 0.00 & 0.00 & 0.00 & 0.00 & 0.00 & 0.00 & 0.00 \\
\hline $\mathrm{ZnO}$ & 2.36 & 2.41 & 2.36 & 2.42 & 2.36 & 2.36 & 2.36 & 2.42 & 3.36 & 3.48 & 2.36 & 2.53 \\
\hline $\mathrm{ZrO}_{2}$ & 4.80 & 4.18 & 4.80 & 4.52 & 4.80 & 4.39 & 4.80 & 4.54 & 4.80 & 4.73 & 6.07 & 5.89 \\
\hline $\mathrm{Cl}$ & 0.71 & 0.68 & 0.71 & 0.69 & 0.71 & 0.71 & 0.71 & 0.62 & 0.71 & 0.76 & 0.71 & 0.69 \\
\hline $\mathrm{F}$ & 0.00 & NA & 0.00 & NA & 0.00 & NA & 0.00 & NA & 0.00 & NA & 0.00 & NA \\
\hline $\mathrm{P}_{2} \mathrm{O}_{5}$ & 0.00 & 0.04 & 0.00 & 0.05 & 0.00 & 0.05 & 0.00 & 0.05 & 0.00 & 0.05 & 0.00 & 0.05 \\
\hline $\mathrm{SO}_{3}$ & 0.19 & 0.19 & 0.19 & 0.19 & 0.19 & 0.19 & 0.19 & 0.21 & 0.19 & 0.20 & 0.19 & 0.19 \\
\hline SUM & 100.0 & 100.1 & 100.0 & 100.4 & 100.0 & 100.1 & 100.0 & 100.2 & 100.0 & 99.6 & 100.0 & 99.8 \\
\hline
\end{tabular}

* - Analyzed by X-ray fluorescence except for boron which was measured by DCP

NA - Not analyzed 
Table 2.2. Target and Analyzed Compositions (wt\%) of Seventeen ORPLA Crucible Glasses (continued).

\begin{tabular}{|c|c|c|c|c|c|c|c|c|c|c|c|c|}
\hline \multirow{2}{*}{$\begin{array}{c}\text { GLASS } \\
\text { Oxides }\end{array}$} & \multicolumn{2}{|c|}{ ORPLA7 } & \multicolumn{2}{|c|}{ ORPLA8 } & \multicolumn{2}{|c|}{ ORPLA9 } & \multicolumn{2}{|c|}{ ORPLA10 } & \multicolumn{2}{|c|}{ ORPLA11 } & \multicolumn{2}{|c|}{ ORPLA12 } \\
\hline & Target & Analyzed ${ }^{*}$ & Target & Analyzed ${ }^{*}$ & Target & Analyzed ${ }^{*}$ & Target & Analyzed* & Target & Analyzed ${ }^{*}$ & Target & Analyzed* \\
\hline $\mathrm{Al}_{2} \mathrm{O}_{3}$ & 10.88 & 11.03 & 5.82 & 6.09 & 10.90 & 10.86 & 10.90 & 10.88 & 10.90 & 10.97 & 10.77 & 10.48 \\
\hline $\mathrm{B}_{2} \mathrm{O}_{3}$ & 7.78 & NA & 8.48 & NA & 7.80 & NA & 7.80 & NA & 7.00 & NA & 7.13 & 7.18 \\
\hline $\mathrm{CaO}$ & 1.47 & 1.52 & 0.00 & 0.07 & 6.52 & 6.46 & 6.52 & 6.54 & 2.00 & 2.16 & 2.03 & 2.17 \\
\hline $\mathrm{Cr}_{2} \mathrm{O}_{3}$ & 0.49 & 0.61 & 0.49 & 0.66 & 0.49 & 0.60 & 0.49 & 0.61 & 0.49 & 0.65 & 0.50 & 0.65 \\
\hline $\mathrm{Cs}_{2} \mathrm{O}$ (spike) & 0.19 & 0.19 & 0.19 & 0.20 & 0.19 & 0.18 & 0.19 & 0.16 & 0.19 & 0.19 & 0.18 & 0.19 \\
\hline $\mathrm{Fe}_{2} \mathrm{O}_{3}$ & 0.94 & 0.98 & 2.70 & 2.95 & 0.91 & 0.90 & 0.91 & 0.93 & 0.91 & 1.01 & 0.93 & 1.02 \\
\hline $\mathrm{K}_{2} \mathrm{O}$ & 0.56 & 0.68 & 0.56 & 0.64 & 0.56 & 0.57 & 0.56 & 0.57 & 0.56 & 0.66 & 0.54 & 0.57 \\
\hline $\mathrm{MgO}$ & 0.91 & 0.98 & 3.37 & 3.22 & 0.91 & 1.03 & 0.91 & 1.03 & 0.91 & 0.83 & 0.93 & 0.86 \\
\hline $\mathrm{Na}_{2} \mathrm{O}$ & 25.00 & 25.18 & 25.00 & 23.49 & 25.00 & 25.31 & 25.00 & 25.44 & 25.00 & 23.64 & 24.00 & 23.07 \\
\hline $\mathrm{SiO}_{2}$ & 40.50 & 40.17 & 42.10 & 41.68 & 35.51 & 34.94 & 35.78 & 34.97 & 40.15 & 39.99 & 41.00 & 40.93 \\
\hline $\mathrm{SnO}_{2}$ & 1.00 & 1.08 & 1.94 & 2.29 & 2.00 & 2.28 & 2.68 & 2.92 & 2.70 & 3.08 & 2.75 & 3.14 \\
\hline $\mathrm{TiO}_{2}$ & 0.00 & 0.01 & 1.55 & 1.77 & 0.00 & 0.03 & 0.00 & 0.03 & 0.00 & 0.03 & 0.00 & 0.02 \\
\hline $\mathrm{V}_{2} \mathrm{O}_{5}$ & 0.94 & 1.00 & 0.00 & 0.00 & 0.94 & 1.01 & 0.00 & 0.00 & 0.00 & 0.00 & 0.00 & 0.00 \\
\hline $\mathrm{ZnO}$ & 2.36 & 2.33 & 1.00 & 1.13 & 2.36 & 2.31 & 2.36 & 2.36 & 2.36 & 2.59 & 2.45 & 2.66 \\
\hline $\mathrm{ZrO}_{2}$ & 6.07 & 5.29 & 5.90 & 6.05 & 5.00 & 4.61 & 5.00 & 4.64 & 5.94 & 5.97 & 5.95 & 5.93 \\
\hline $\mathrm{Cl}$ & 0.71 & 0.67 & 0.71 & 0.69 & 0.71 & 0.63 & 0.71 & 0.60 & 0.71 & 0.71 & 0.68 & 0.70 \\
\hline $\mathrm{F}$ & 0.00 & NA & 0.00 & NA & 0.00 & NA & 0.00 & NA & 0.00 & NA & 0.00 & NA \\
\hline $\mathrm{P}_{2} \mathrm{O}_{5}$ & 0.00 & 0.04 & 0.00 & 0.05 & 0.00 & 0.03 & 0.00 & 0.04 & 0.00 & 0.04 & 0.00 & 0.01 \\
\hline $\mathrm{SO}_{3}$ & 0.19 & 0.20 & 0.19 & 0.23 & 0.19 & 0.18 & 0.19 & 0.19 & 0.19 & 0.19 & 0.18 & 0.17 \\
\hline SUM & 100.0 & 99.7 & 100.0 & 99.7 & 100.0 & 99.7 & 100.0 & 99.7 & 100.0 & 99.7 & 100.0 & 99.8 \\
\hline
\end{tabular}


Table 2.2. Target and Analyzed Compositions (wt\%) of Seventeen ORPLA Crucible Glasses (continued).

\begin{tabular}{|c|c|c|c|c|c|c|c|c|c|c|}
\hline GLASS & \multicolumn{2}{|c|}{ ORPLA13 } & \multicolumn{2}{|c|}{ ORPLA14 } & \multicolumn{2}{|c|}{ ORPLA15 } & \multicolumn{2}{|c|}{ ORPLA16 } & \multicolumn{2}{|c|}{ ORPLA17 } \\
\hline Oxides & Target & Analyzed ${ }^{*}$ & Target & Analyzed* & Target & Analyzed ${ }^{*}$ & Target & Analyzed* & Target & Analyzed* \\
\hline $\mathrm{Al}_{2} \mathrm{O}_{3}$ & 10.83 & 10.64 & 10.70 & 10.37 & 9.46 & 9.20 & 9.87 & 9.80 & 9.89 & 9.70 \\
\hline $\mathrm{B}_{2} \mathrm{O}_{3}$ & 7.07 & 7.15 & 7.20 & 7.42 & 8.65 & 8.90 & 7.78 & 7.85 & 8.78 & 8.88 \\
\hline $\mathrm{CaO}$ & 2.01 & 2.11 & 2.05 & 2.00 & 3.34 & 3.53 & 1.47 & 1.53 & 2.99 & 3.04 \\
\hline $\mathrm{Cr}_{2} \mathrm{O}_{3}$ & 0.49 & 0.65 & 0.50 & 0.65 & 0.50 & 0.65 & 0.49 & 0.64 & 0.50 & 0.65 \\
\hline $\mathrm{Cs}_{2} \mathrm{O}$ (spike) & 0.18 & 0.19 & 0.17 & 0.19 & 0.15 & 0.16 & 0.19 & 0.18 & 0.15 & 0.17 \\
\hline $\mathrm{Fe}_{2} \mathrm{O}_{3}$ & 0.92 & 0.99 & 0.94 & 0.97 & 0.93 & 1.04 & 0.94 & 1.02 & 0.94 & 0.99 \\
\hline $\mathrm{K}_{2} \mathrm{O}$ & 0.55 & 0.57 & 0.53 & 0.54 & 0.54 & 0.55 & 0.56 & 0.55 & 0.54 & 0.54 \\
\hline $\mathrm{MgO}$ & 0.92 & 0.89 & 0.94 & 0.90 & 0.93 & 0.87 & 0.91 & 0.97 & 0.91 & 0.86 \\
\hline $\mathrm{Na}_{2} \mathrm{O}$ & 24.50 & 23.53 & 23.50 & 23.19 & 24.00 & 22.57 & 25.00 & 24.26 & 24.00 & 23.44 \\
\hline $\mathrm{SiO}_{2}$ & 40.61 & 40.80 & 41.38 & 41.13 & 39.50 & 39.52 & 41.58 & 41.45 & 40.03 & 40.21 \\
\hline $\mathrm{SnO}_{2}$ & 2.72 & 3.03 & 2.78 & 3.29 & 2.75 & 3.27 & 1.00 & 1.22 & 1.00 & 1.18 \\
\hline $\mathrm{TiO}_{2}$ & 0.00 & 0.01 & 0.00 & 0.01 & 0.00 & 0.01 & 0.00 & 0.02 & 0.00 & 0.02 \\
\hline $\mathrm{V}_{2} \mathrm{O}_{5}$ & 0.00 & 0.00 & 0.00 & 0.00 & 0.00 & 0.00 & 0.94 & 1.11 & 0.98 & 1.10 \\
\hline $\mathrm{ZnO}$ & 2.42 & 2.60 & 2.47 & 2.58 & 2.45 & 2.68 & 2.36 & 2.49 & 2.36 & 2.40 \\
\hline $\mathrm{ZrO}_{2}$ & 5.89 & 5.71 & 6.00 & 5.80 & 5.95 & 6.03 & 6.00 & 6.00 & 6.07 & 5.78 \\
\hline $\mathrm{Cl}$ & 0.69 & 0.71 & 0.66 & 0.66 & 0.68 & 0.71 & 0.71 & 0.58 & 0.68 & 0.67 \\
\hline $\mathrm{F}$ & 0.00 & NA & 0.00 & NA & 0.00 & NA & 0.00 & NA & 0.00 & NA \\
\hline $\mathrm{P}_{2} \mathrm{O}_{5}$ & 0.00 & 0.01 & 0.00 & 0.02 & 0.00 & 0.02 & 0.00 & 0.00 & 0.00 & 0.02 \\
\hline $\mathrm{SO}_{3}$ & 0.19 & 0.19 & 0.18 & 0.17 & 0.18 & 0.18 & 0.19 & 0.17 & 0.18 & 0.18 \\
\hline SUM & 100.0 & 99.8 & 100.0 & 99.9 & 100.0 & 99.9 & 100.0 & 99.8 & 100.0 & 99.8 \\
\hline
\end{tabular}

* Analyzed by X-ray fluorescence except for boron which was measured by DCP

NA - Not analyzed 
Table 2.3. Descriptions of Seventeen As-Melted and Heat Treated ORPLA Crucible Glasses.

\begin{tabular}{|c|c|c|}
\hline Glass ID & As-melted glass & $\begin{array}{l}\text { Glass remelted at } 1200^{\circ} \mathrm{C} \text { for } 1 \text { hour, heat treated for } 20 \text { hours at } \\
\qquad 950^{\circ} \mathrm{C} \text {, and quenched. }\end{array}$ \\
\hline ORPLA1 & Clear glass & Not tested \\
\hline ORPLA2 & Clear glass & Not tested \\
\hline ORPLA3 & Clear glass & Mostly clear glass. $<<0.1$ vol\% of small Cr-Fe spinel crystals \\
\hline ORPLA4 & Clear glass & Not tested \\
\hline ORPLA5 & Clear glass & Clear glass. $<<0.1$ vol\% of small Cr-Fe spinel crystals \\
\hline ORPLA6 & Clear glass. $<<0.1$ vol\% of small Cr oxide crystals & Clear glass. $<<0.1$ vol\% of small Cr-Fe spinel crystals \\
\hline ORPLA7 & Clear glass. $<<0.1$ vol\% of small Cr oxide crystals & Clear glass. $<<0.1$ vol\% of small Cr-Fe spinel crystals \\
\hline ORPLA8 & Clear glass & Not tested \\
\hline ORPLA9 & Clear glass & Clear glass. $<<0.1$ vol\% of Na-Zr-silicate crystals \\
\hline ORPLA10 & Clear glass & Mostly clear glass. $\sim 0.1$ vol\% of Na-Zr-silicate crystals \\
\hline ORPLA11 & Clear glass & Clear glass \\
\hline ORPLA12 & Clear glass. $<<0.1$ vol\% of small Cr-Fe spinel crystals & Clear glass. $<<0.1$ vol\% of small Cr-Fe spinel crystals \\
\hline ORPLA13 & Clear glass. $<<0.1$ vol\% of small Cr oxide crystals & Clear glass. $<0.1$ vol\% of Na-Zr-silicate crystals \\
\hline ORPLA14 & Clear glass. $<<0.1$ vol\% of small Cr oxide crystals & Clear glass. $<0.1$ vol\% of Na-Zr-silicate crystals + Cr crystal \\
\hline ORPLA15 & Clear glass. $<<0.1$ vol\% of small $\mathrm{Cr}+\mathrm{Zn}$ crystals & $0.2-0.3 \mathrm{vol} \%$ of Na-Zr-silicate crystals + Sn crystal \\
\hline ORPLA16 & Clear glass. $<<0.1$ vol\% of small $\mathrm{Cr}+\mathrm{Zn}$ crystals & Clear glass \\
\hline ORPLA17 & Clear glass. $<0.1$ vol\% of small Cr+Zn crystals & Clear glass. $\sim 0.1$ vol\% of Na-Zr-silicate crystals + Cr oxide crystals \\
\hline
\end{tabular}


Table 2.4. Measured Sulfate Solubility Limits in Seventeen ORPLA Glasses.

\begin{tabular}{|c|c|c|c|}
\hline \multirow{2}{*}{ Sample ID } & \multicolumn{3}{|c|}{ SO $_{3}$ Content (wt\%) (Target Minimum $=0$ to 0.3 wt\%) } \\
\cline { 2 - 3 } & \multicolumn{2}{|c|}{ Batch Saturation } & \multirow{2}{*}{ Bubbling } \\
\cline { 2 - 3 } & As-Melted & After Acid Wash & - \\
\hline ORPLA1S4 & 0.68 & 0.48 & - \\
\hline ORPLA2 S4 & 0.46 & 0.42 & - \\
\hline ORPLA3 S4 & 0.42 & 0.41 & - \\
\hline ORPLA4S4 & 0.85 & 0.44 & - \\
\hline ORPLA5S4 & 0.34 & 0.34 & - \\
\hline ORPLA6S4 & 0.32 & 0.33 & - \\
\hline ORPLA7S4 & 0.32 & 0.28 & - \\
\hline ORPLA8S4 & 0.40 & 0.39 & - \\
\hline ORPLA9S4 & 0.61 & 0.55 & - \\
\hline ORPLA10S4 & 0.53 & 0.49 & - \\
\hline ORPLA11S4 & 0.30 & 0.29 & - \\
\hline ORPLA12S4 & 0.27 & 0.27 & - \\
\hline ORPLA13S4 & 0.31 & 0.30 & - \\
\hline ORPLA14S4 & 0.28 & 0.28 & - \\
\hline ORPLA15S4 & 0.29 & 0.27 & - \\
\hline ORPLA16S4 & 0.30 & 0.30 & -32 \\
\hline ORPLA17S4 & 0.32 & & - \\
\hline - Empty data field & & 0.32 & - \\
\hline
\end{tabular}


Table 2.5. Results of 7-day PCT (at $90^{\circ} \mathrm{C}$ ) and VHT (at $200^{\circ} \mathrm{C}$ for 24 Days) for Seventeen ORPLA Crucible Glasses.

\begin{tabular}{|c|c|c|c|c|c|c|c|c|c|}
\hline Glass ID & ORPLA1 & ORPLA2 & ORPLA3 & ORPLA4 & ORPLA5 & ORPLA6 & ORPLA7 & ORPLA8 & ORPLA9 \\
\hline \multicolumn{10}{|c|}{ 7-Day PCT, Stainless Steel Vessel; S/V=2000m ${ }^{-1} \quad(p p m)$} \\
\hline $\mathrm{B}$ & 51.36 & 55.35 & 50.28 & 66.42 & 27.53 & 27.78 & 31.69 & 75.46 & 43.27 \\
\hline $\mathrm{Na}$ & 287.20 & 291.10 & 278.40 & 396.10 & 276.30 & 233.90 & 243.10 & 381.10 & 348.60 \\
\hline $\mathrm{Si}$ & 78.22 & 75.22 & 74.00 & 104.90 & 90.10 & 72.40 & 71.97 & 109.10 & 77.16 \\
\hline \multicolumn{10}{|c|}{ Normalized Concentrations (g/L) } \\
\hline $\mathrm{B}$ & 1.84 & 1.98 & 1.80 & 2.38 & 1.31 & 1.15 & 1.31 & 2.86 & 1.79 \\
\hline $\mathrm{Na}$ & 1.55 & 1.57 & 1.50 & 2.14 & 1.49 & 1.26 & 1.31 & 2.05 & 1.88 \\
\hline $\mathrm{Si}$ & 0.41 & 0.39 & 0.38 & 0.54 & 0.44 & 0.37 & 0.38 & 0.55 & 0.46 \\
\hline $\mathrm{pH}$ & 11.74 & 11.75 & 11.7 & 11.85 & 11.76 & 11.66 & 11.68 & 11.85 & 11.97 \\
\hline \multicolumn{10}{|c|}{ 7-Day PCT Normalized Mass Loss $\left(\mathrm{g} / \mathrm{m}^{2}\right)$} \\
\hline $\mathrm{B}$ & 0.92 & 0.99 & 0.90 & 1.19 & 0.65 & 0.57 & 0.66 & 1.43 & 0.89 \\
\hline $\mathrm{Na}$ & 0.77 & 0.78 & 0.75 & 1.07 & 0.74 & 0.63 & 0.66 & 1.03 & 0.94 \\
\hline $\mathrm{Si}$ & 0.20 & 0.19 & 0.19 & 0.27 & 0.22 & 0.18 & 0.19 & 0.28 & 0.23 \\
\hline \multicolumn{10}{|c|}{ 7-Day PCT Normalized Loss Rate $\left(\mathrm{g} / \mathrm{m}^{2} / \mathrm{d}\right)$} \\
\hline $\mathrm{B}$ & 0.13 & 0.14 & 0.13 & 0.17 & 0.09 & 0.08 & 0.09 & 0.20 & 0.13 \\
\hline $\mathrm{Na}$ & 0.11 & 0.11 & 0.11 & 0.15 & 0.11 & 0.09 & 0.09 & 0.15 & 0.13 \\
\hline $\mathrm{Si}$ & 0.03 & 0.03 & 0.03 & 0.04 & 0.03 & 0.03 & 0.03 & 0.04 & 0.03 \\
\hline \multicolumn{10}{|c|}{ VHT Alteration (24 days at $200^{\circ} \mathrm{C}$ ) - Measurements on ORPLA and ORPLAS4 Samples } \\
\hline Alteration Depth $(\mu \mathrm{m})$ & $>1362$ & 1179 & 1039 & 1031 & 934 & 821 & 613 & 894 & 514 \\
\hline Alteration Rate (g/m²/day)* & $>150$ & 130 & 115 & 114 & 103 & 91 & 68 & 99 & 57 \\
\hline Alteration Depth $(\mu \mathrm{m})$ & $>1264$ & 858 & 1212 & 918 & $>1225$ & 561 & 680 & $>1238$ & 340 \\
\hline Alteration Rate (g/m²/day)* & $>140$ & 95 & 134 & 101 & $>135$ & 62 & 75 & $>137$ & 38 \\
\hline
\end{tabular}

* Alteration rates calculated using estimated density of $2.65 \mathrm{~g} / \mathrm{cc}$ 
Table 2.5. Results of 7-day PCT (at $90^{\circ} \mathrm{C}$ ) and VHT (at $200^{\circ} \mathrm{C}$ for 24 Days) for Seventeen ORPLA Crucible Glasses (continued).

\begin{tabular}{|c|c|c|c|c|c|c|c|c|}
\hline Glass ID & ORPLA10 & ORPLA11 & ORPLA12 & ORPLA13 & ORPLA14 & ORPLA15 & ORPLA16 & ORPLA17 \\
\hline \multicolumn{9}{|c|}{ 7-Day PCT, Stainless Steel Vessel; S/V=2000m ${ }^{-1} \quad(\mathrm{ppm})$} \\
\hline B & 42.11 & 21.12 & 16.64 & 19.29 & 14.33 & 35.39 & 36.25 & 42.33 \\
\hline $\mathrm{Na}$ & 358.70 & 224.00 & 180.30 & 198.60 & 159.90 & 242.40 & 258.70 & 238.70 \\
\hline $\mathrm{Si}$ & 77.32 & 74.37 & 75.36 & 75.54 & 70.40 & 69.91 & 76.51 & 66.98 \\
\hline \multicolumn{9}{|c|}{ Normalized Concentrations (g/L) } \\
\hline $\mathrm{B}$ & 1.74 & 0.97 & 0.75 & 0.88 & 0.64 & 1.32 & 1.50 & 1.55 \\
\hline $\mathrm{Na}$ & 1.93 & 1.21 & 1.01 & 1.09 & 0.92 & 1.36 & 1.39 & 1.34 \\
\hline $\mathrm{Si}$ & 0.46 & 0.40 & 0.39 & 0.40 & 0.36 & 0.38 & 0.39 & 0.36 \\
\hline $\mathrm{pH}$ & 11.99 & 11.67 & 11.5 & 11.58 & 11.45 & 11.58 & 11.61 & 11.55 \\
\hline \multicolumn{9}{|c|}{ 7-Day PCT Normalized Mass Loss $\left(\mathrm{g} / \mathrm{m}^{2}\right)$} \\
\hline $\mathrm{B}$ & 0.87 & 0.49 & 0.38 & 0.44 & 0.32 & 0.66 & 0.75 & 0.78 \\
\hline $\mathrm{Na}$ & 0.97 & 0.60 & 0.51 & 0.55 & 0.46 & 0.68 & 0.70 & 0.67 \\
\hline $\mathrm{Si}$ & 0.23 & 0.20 & 0.20 & 0.20 & 0.18 & 0.19 & 0.20 & 0.18 \\
\hline \multicolumn{9}{|c|}{ 7-Day PCT Normalized Loss Rate (g/m²/d) } \\
\hline $\mathrm{B}$ & 0.12 & 0.07 & 0.05 & 0.06 & 0.05 & 0.09 & 0.11 & 0.11 \\
\hline $\mathrm{Na}$ & 0.14 & 0.09 & 0.07 & 0.08 & 0.07 & 0.10 & 0.10 & 0.10 \\
\hline Si & 0.03 & 0.03 & 0.03 & 0.03 & 0.03 & 0.03 & 0.03 & 0.03 \\
\hline \multicolumn{9}{|c|}{ VHT Alteration (24 days at $200^{\circ} \mathrm{C}$ ) - Measurements on ORPLA and ORPLAS4 Samples } \\
\hline Alteration Depth $(\mu \mathrm{m})$ & 136 & $>1252$ & 145 & 183 & 77 & 230 & 975 & 674 \\
\hline Alteration Rate (g/m²/day)* & 15 & $>138$ & 16 & 20 & 9 & 25 & 108 & 74 \\
\hline Alteration Depth $(\mu \mathrm{m})$ & 114 & $>1301$ & 168 & 695 & 5 & 279 & 1016 & 600 to 1115 \\
\hline Alteration Rate (g/m²/day)* & 13 & $>144$ & 19 & 77 & 1 & 31 & 112 & 66 to 123 \\
\hline
\end{tabular}

* Alteration rates calculated using estimated density of $2.65 \mathrm{~g} / \mathrm{cc}$ 
Table 2.6. Viscosities and Electrical Conductivities of Seventeen ORPLA Crucible Glasses.

\begin{tabular}{|c|c|c|c|c|c|c|c|c|c|}
\hline $\begin{array}{c}\text { Glass } \\
\text { ID }\end{array}$ & ORPLA1 & ORPLA2 & ORPLA3 & ORPLA4 & ORPLA5 & ORPLA6 & ORPLA7 & ORPLA8 & ORPLA9 \\
\hline \multicolumn{10}{|c|}{ Viscosity (poise) } \\
\hline $900^{\circ} \mathrm{C}$ & 1747 & 1919 & 2118 & 833 & 5221 & 4170 & 5833 & 2045 & 1752 \\
\hline $950^{\circ} \mathrm{C}$ & 701 & 814 & 799 & 383 & 2040 & 1749 & 1989 & 796 & 624 \\
\hline $1000^{\circ} \mathrm{C}$ & 323 & 386 & 356 & 194 & 896 & 808 & 798 & 354 & 268 \\
\hline $1050^{\circ} \mathrm{C}$ & 167 & 200 & 181 & 107 & 434 & 405 & 364 & 175 & 132 \\
\hline $1100^{\circ} \mathrm{C}$ & 94 & 112 & 101 & 63 & 228 & 217 & 184 & 94 & 73 \\
\hline $1150^{\circ} \mathrm{C}$ & 57 & 67 & 61 & 39 & 128 & 124 & 101 & 55 & 44 \\
\hline $1200^{\circ} \mathrm{C}$ & 36 & 42 & 40 & 25 & 76 & 74 & 60 & 34 & 28 \\
\hline $1250^{\circ} \mathrm{C}$ & 25 & 28 & 27 & 17 & 48 & 47 & 37 & 22 & 19 \\
\hline \multicolumn{10}{|c|}{ Electrical Conductivity (S/cm) } \\
\hline $900^{\circ} \mathrm{C}$ & 0.305 & 0.288 & 0.209 & 0.280 & 0.221 & 0.099 & 0.261 & 0.294 & 0.262 \\
\hline $950^{\circ} \mathrm{C}$ & 0.372 & 0.351 & 0.286 & 0.347 & 0.316 & 0.198 & 0.319 & 0.366 & 0.320 \\
\hline $1000^{\circ} \mathrm{C}$ & 0.447 & 0.422 & 0.373 & 0.421 & 0.419 & 0.325 & 0.385 & 0.448 & 0.384 \\
\hline $1050^{\circ} \mathrm{C}$ & 0.530 & 0.500 & 0.469 & 0.505 & 0.525 & 0.470 & 0.458 & 0.540 & 0.455 \\
\hline $1100^{\circ} \mathrm{C}$ & 0.621 & 0.585 & 0.572 & 0.597 & 0.631 & 0.627 & 0.537 & 0.641 & 0.532 \\
\hline $1150^{\circ} \mathrm{C}$ & 0.719 & 0.677 & 0.681 & 0.697 & 0.735 & 0.789 & 0.624 & 0.753 & 0.615 \\
\hline $1200^{\circ} \mathrm{C}$ & 0.824 & 0.776 & 0.794 & 0.806 & 0.837 & 0.953 & 0.717 & 0.874 & 0.705 \\
\hline $1250^{\circ} \mathrm{C}$ & 0.936 & 0.881 & 0.911 & 0.923 & 0.935 & 1.115 & 0.816 & 1.005 & 0.800 \\
\hline
\end{tabular}


Table 2.6. Viscosities and Electrical Conductivities of Seventeen ORPLA Crucible Glasses (continued).

\begin{tabular}{|c|c|c|c|c|c|c|c|c|}
\hline $\begin{array}{c}\text { Glass } \\
\text { ID }\end{array}$ & ORPLA10 & ORPLA11 & ORPLA12 & ORPLA13 & ORPLA14 & ORPLA15 & ORPLA16 & ORPLA17 \\
\hline \multicolumn{9}{|c|}{ Viscosity (poise) } \\
\hline $900^{\circ} \mathrm{C}$ & 1620 & 4242 & 5978 & 5089 & 6741 & 2253 & 3863 & 2879 \\
\hline $950^{\circ} \mathrm{C}$ & 653 & 1696 & 2218 & 1958 & 2494 & 909 & 1461 & 1095 \\
\hline $1000^{\circ} \mathrm{C}$ & 296 & 757 & 941 & 851 & 1057 & 413 & 636 & 478 \\
\hline $1050^{\circ} \mathrm{C}$ & 148 & 371 & 445 & 409 & 500 & 207 & 310 & 233 \\
\hline $1100^{\circ} \mathrm{C}$ & 80 & 196 & 230 & 214 & 259 & 112 & 165 & 124 \\
\hline $1150^{\circ} \mathrm{C}$ & 47 & 110 & 128 & 120 & 145 & 65 & 95 & 71 \\
\hline $1200^{\circ} \mathrm{C}$ & 29 & 66 & 76 & 71 & 86 & 40 & 58 & 44 \\
\hline $1250^{\circ} \mathrm{C}$ & 18 & 41 & 47 & 44 & 54 & 26 & 38 & 28 \\
\hline \multicolumn{9}{|c|}{ Electrical Conductivity (S/cm) } \\
\hline $900^{\circ} \mathrm{C}$ & 0.227 & 0.253 & 0.208 & 0.148 & 0.148 & 0.275 & 0.211 & 0.171 \\
\hline $950^{\circ} \mathrm{C}$ & 0.308 & 0.315 & 0.264 & 0.239 & 0.239 & 0.342 & 0.289 & 0.260 \\
\hline $1000^{\circ} \mathrm{C}$ & 0.398 & 0.385 & 0.329 & 0.336 & 0.336 & 0.418 & 0.378 & 0.350 \\
\hline $1050^{\circ} \mathrm{C}$ & 0.496 & 0.463 & 0.403 & 0.435 & 0.435 & 0.504 & 0.475 & 0.438 \\
\hline $1100^{\circ} \mathrm{C}$ & 0.600 & 0.550 & 0.486 & 0.531 & 0.531 & 0.598 & 0.580 & 0.521 \\
\hline $1150^{\circ} \mathrm{C}$ & 0.709 & 0.645 & 0.579 & 0.623 & 0.623 & 0.702 & 0.691 & 0.599 \\
\hline $1200^{\circ} \mathrm{C}$ & 0.822 & 0.749 & 0.682 & 0.710 & 0.710 & 0.814 & 0.807 & 0.672 \\
\hline $1250^{\circ} \mathrm{C}$ & 0.937 & 0.860 & 0.794 & 0.792 & 0.792 & 0.936 & 0.927 & 0.738 \\
\hline
\end{tabular}


Table 2.7. Results of K-3 Corrosion Testing for Seventeen ORPLA Crucible Glasses.

\begin{tabular}{|c|c|c|c|}
\hline Glass ID & $\begin{array}{c}\text { Neck loss } \\
\text { (inches) }\end{array}$ & $\begin{array}{c}\text { Depth of altered } \\
\text { zone (inches) }\end{array}$ & $\begin{array}{c}\text { Half-down loss } \\
\text { (inches) }\end{array}$ \\
\hline ORPLA1 & 0.108 & 0.027 & 0.002 \\
\hline ORPLA2 & 0.071 & 0.021 & 0.002 \\
\hline ORPLA3 & 0.041 & 0.021 & 0.001 \\
\hline ORPLA4 & 0.123 & 0.023 & 0.003 \\
\hline ORPLA5 & 0.015 & 0.017 & 0.001 \\
\hline ORPLA6 & 0.024 & 0.021 & 0.001 \\
\hline ORPLA7 & 0.030 & 0.018 & 0.001 \\
\hline ORPLA8 & 0.054 & 0.022 & 0.001 \\
\hline ORPLA9 & 0.083 & 0.030 & $\begin{array}{c}\text { Coupon expanded }- \\
\text { no measurable loss }\end{array}$ \\
\hline ORPLA10 & 0.073 & 0.029 & $\begin{array}{c}\text { Coupon expanded }- \\
\text { no measurable loss }\end{array}$ \\
\hline ORPLA11 & 0.028 & 0.028 & $\begin{array}{c}\text { Coupon expanded }- \\
\text { no measurable loss }\end{array}$ \\
\hline ORPLA12 & 0.015 & 0.020 & $\begin{array}{c}\text { Coupon expanded }- \\
\text { no measurable loss }\end{array}$ \\
\hline ORPLA13 & 0.025 & 0.017 & $\begin{array}{c}\text { Coupon expanded }- \\
\text { no measurable loss }\end{array}$ \\
\hline ORPLA14 & 0.012 & 0.017 & $\begin{array}{c}\text { Coupon expanded }- \\
\text { no measurable loss }\end{array}$ \\
\hline ORPLA15 & 0.036 & 0.023 & $\begin{array}{c}\text { Coupon expanded }- \\
\text { no measurable loss }\end{array}$ \\
\hline ORPLA16 & 0.039 & 0.018 & $\begin{array}{c}\text { Coupon expanded }- \\
\text { no measurable loss }\end{array}$ \\
\hline ORPLA17 & 0.042 & 0.024 & $\begin{array}{c}\text { Coupon expanded }- \\
\text { no measurable loss }\end{array}$ \\
\hline
\end{tabular}


Table 2.8. Summary of Test Results for Selected ORPLA Glass Formulation ORPLA15 and Comparison to ILAW Requirements.

\begin{tabular}{|c|c|c|}
\hline Test & Requirement $[45,46]$ & $\begin{array}{l}\text { Test Result for } \\
\text { ORPLA15 }\end{array}$ \\
\hline Density of glass & $<3.7 \mathrm{~g} / \mathrm{cc}$ & Not measured \\
\hline Crystalline Phase & Phase identification & $\begin{array}{l}\text { Clear homogeneous glass } \\
\text { with no more than } 0.3 \text { vol\% crystals } \\
\text { after heat treatment at } 950^{\circ} \mathrm{C} \text { for } 20 \\
\text { hours }\end{array}$ \\
\hline Liquidus & $<950^{\circ} \mathrm{C}$ & $<950^{\circ} \mathrm{C}$ \\
\hline Centerline Canister Cooling & Phase identification & Not measured \\
\hline PCT B $\left(g / m^{2}\right)$ & $<2.0 \mathrm{~g} / \mathrm{m}^{2}$ & $0.66 \mathrm{~g} / \mathrm{m}^{2}$ \\
\hline PCT Na $\left(g / m^{2}\right)$ & $<2.0 \mathrm{~g} / \mathrm{m}^{2}$ & $0.68 \mathrm{~g} / \mathrm{m}^{2}$ \\
\hline PCT Si $\left(\mathrm{g} / \mathrm{m}^{2}\right)$ & $<2.0 \mathrm{~g} / \mathrm{m}^{2}$ & $0.19 \mathrm{~g} / \mathrm{m}^{2}$ \\
\hline VHT at $200^{\circ} \mathrm{C}\left(\mathrm{g} / \mathrm{m}^{2} /\right.$ day $)$ & $<50 \mathrm{~g} / \mathrm{m}^{2} /$ day & $\begin{array}{c}25 \text { and } 31 \mathrm{~g} / \mathrm{m}^{2} / \text { day } \\
\text { (measurements on ORPLA and } \\
\text { ORPLAS4 samples) } \\
\end{array}$ \\
\hline Viscosity (poise) at $1100^{\circ} \mathrm{C}$ & 10 to $150 \mathrm{P}$ & $112 \mathrm{P}$ \\
\hline Conductivity $(\mathrm{S} / \mathrm{cm})$ at $1100^{\circ} \mathrm{C}$ & 0.2 to $0.7 \mathrm{~S} / \mathrm{cm}$ & $0.598 \mathrm{~S} / \mathrm{cm}$ \\
\hline $\mathrm{T}_{\mathrm{G}}\left({ }^{\circ} \mathrm{C}\right)$ & Report for modeling & Not measured \\
\hline
\end{tabular}


Table 2.9. Oxide Composition of AN-105 Simulant and ORPLA15 Glass Composition Used in Melter Tests (wt\%).

\begin{tabular}{|c|c|c|c|}
\hline Component & $\begin{array}{c}\text { AN-105 waste } \\
\text { contribution }\end{array}$ & $\begin{array}{c}\text { Glass former } \\
\text { additives }\end{array}$ & $\begin{array}{c}\text { ORPLA15 } \\
\text { (for AN-105) }\end{array}$ \\
\hline Loading & $31.6 \%$ & $68.4 \%$ & - \\
\hline $\mathrm{Al}_{2} \mathrm{O}_{3}$ & 5.589 & 3.86 & 9.45 \\
\hline $\mathrm{B}_{2} \mathrm{O}_{3}$ & 0.024 & 8.58 & 8.60 \\
\hline $\mathrm{CaO}$ & - & 3.32 & 3.32 \\
\hline $\mathrm{Cr}_{2} \mathrm{O}_{3}$ & 0.021 & 0.47 & 0.49 \\
\hline $\mathrm{Cs}_{2} \mathrm{O}$ & 0.144 & - & 0.14 \\
\hline $\mathrm{Fe}_{2} \mathrm{O}_{3}$ & - & 0.92 & 0.92 \\
\hline $\mathrm{K}_{2} \mathrm{O}$ & 0.537 & - & 0.537 \\
\hline $\mathrm{MgO}$ & - & 0.92 & 0.92 \\
\hline $\mathrm{Na}_{2} \mathrm{O}^{(\mathrm{a})}$ & $23.405+0.465^{(1)}+0.13^{(2)}$ & - & 24.00 \\
\hline $\mathrm{SiO}_{2}$ & 0.033 & 39.22 & 39.25 \\
\hline $\mathrm{SnO}_{2}$ & - & 2.73 & 2.73 \\
\hline $\mathrm{ZnO}$ & - & 2.43 & 2.43 \\
\hline $\mathrm{ZrO}_{2}$ & - & 5.91 & 5.91 \\
\hline $\mathrm{Cl}$ & 0.680 & - & 0.68 \\
\hline $\mathrm{F}$ & 0.003 & - & 0.00 \\
\hline $\mathrm{P}_{2} \mathrm{O}_{5}$ & 0.000 & - & 0.00 \\
\hline $\mathrm{SO}_{3}{ }^{(b)}$ & $0.60^{(1)}$ & - & 0.60 \\
\hline SUM & 31.6 & 68.4 & 100.0 \\
\hline
\end{tabular}

(a) Simulant was ordered at a concentration of $23.41 \mathrm{wt} \% \mathrm{Na}_{2} \mathrm{O}$ and modified before each melter test with (1) $\mathrm{Na}_{2} \mathrm{SO}_{4}$ and (2) $\mathrm{NaOH}$ additions to obtain $24 \mathrm{wt} \% \mathrm{Na}_{2} \mathrm{O}$ in the glass.

(b) Concentration of $\mathrm{SO}_{3}$ was increased in steps during the melter tests from $0.1 \mathrm{wt} \% \mathrm{SO}_{3}$ in the glass up to $0.6 \mathrm{wt} \%$.

- Empty data field 
Table 2.10a. Glass Former Additives for 1 Liter of AN-105 Simulant (8 M Na) and Corresponding Melter Feed Properties.

\begin{tabular}{|c|c|}
\hline Additives Source & Feed ORPLA15 \\
\hline Additives in Glass (wt\%) & 68.37 \\
\hline Kyanite $\left(\mathrm{Al}_{2} \mathrm{SiO}_{5}\right) 325$ Mesh (Kyanite Mining) (g) & 69.6 \\
\hline $\mathrm{H}_{3} \mathrm{BO}_{3}$ (US Borax - Technical Granular) (g) & 158.43 \\
\hline Wollanstonite NYAD 325 Mesh (NYCO Minerals) (g) & 76.02 \\
\hline $\mathrm{Cr}_{2} \mathrm{O}_{3}$ oxide & $5.00^{(1)}$ \\
\hline $\mathrm{Fe}_{2} \mathrm{O}_{3}$ (Prince Manufacturing) (g) & 7.42 \\
\hline Olivine $\left(\mathrm{Mg}_{2} \mathrm{SiO}_{4}\right) 325$ Mesh (\#180 Unimin) (g) & 20.18 \\
\hline $\mathrm{SiO}_{2}$ (Sil-co-Sil 75 US Silica) (g) & 300.84 \\
\hline $\mathrm{SnO}_{2}$ - Stannous Oxide - Mason color & 28.64 \\
\hline ZnO (KADOX - 920 Zinc Corp. of America) (g) & 25.32 \\
\hline Zircon $\mathrm{ZrSiO}_{4}$ (Flour) Mesh 325 (AM. Mineral) (g) & 92.32 \\
\hline Supplemental $\mathrm{Na}_{2} \mathrm{SO}_{4}$ & Variable - Table 2.10b \\
\hline Addition of Sucrose as Reductant (g) & 78.5 \\
\hline Simulant Weight for 1 liter (g) & 1359 \\
\hline Sum of Additives (g) & 962 \\
\hline Sum of Complete Batch (g) & 2221 \\
\hline Target Final Volume (l) & 1.31 \\
\hline Estimated Density (g/ml) & 1.70 \\
\hline Target Glass Produced (g) & 1033 \\
\hline Target Weight \% Additives in Slurry & 39 \\
\hline Target Glass Yield (g/kg of Feed) & 465 \\
\hline Target Glass Yield (g/l of Feed) & 791 \\
\hline Target Total Solids (g/l of Feed) & 969 \\
\hline Target Additives (g/l of Feed) & 660 \\
\hline
\end{tabular}

${ }^{(1)}$ Note that a $\mathrm{Cr}_{2} \mathrm{O}_{3}$ addition was cut down by $50 \%$ to account for K3-brick contribution.

Table 2.10b. $\mathrm{NaOH}$ and $\mathrm{Na}_{2} \mathrm{SO}_{4}$ Additions Required to Obtain $24 \mathrm{wt} \% \mathrm{Na}_{2} \mathrm{O}$ and Various $\mathrm{SO}_{3}$ Concentrations Ranging from 0.1 to $0.6 \mathrm{wt} \%$ in the ORPLA15 Glass.

\begin{tabular}{|c|c|c|}
\hline $\begin{array}{c}\text { Final } \\
\mathrm{SO}_{3} \mathrm{wt} \%\end{array}$ & $\begin{array}{c}\mathrm{NaOH} \text { needed } \\
\text { per kg of feed } \\
\text { (grams) }\end{array}$ & $\begin{array}{c}\mathrm{Na}_{2} \mathrm{SO}_{4} \text { needed } \\
\text { per kg of feed } \\
\text { (grams) }\end{array}$ \\
\hline 0.1 & 6.26 & 0.84 \\
\hline 0.2 & 5.32 & 1.68 \\
\hline 0.3 & 4.37 & 2.53 \\
\hline 0.4 & 3.45 & 3.37 \\
\hline 0.5 & 2.51 & 4.21 \\
\hline 0.6 & 1.57 & 5.05 \\
\hline
\end{tabular}


Table 2.11. LAW Sub-Envelope C1 (AN-107) Waste Simulant Recipe at 8 Molar Sodium.

\begin{tabular}{|c|c|c|c|c|c|c|c|c|c|c|}
\hline \multirow{3}{*}{\begin{tabular}{|c|}
$\begin{array}{c}\text { Envelope } \\
\text { Constituents }\end{array}$ \\
- \\
$\mathrm{Al}$ \\
\end{tabular}} & \multicolumn{2}{|c|}{$\begin{array}{c}\text { Simulant AN-107 including } \\
\text { pretreatment }\end{array}$} & \multirow{2}{*}{$\begin{array}{c}\text { Glass } \\
\text { Oxides } \\
\text { Loading }\end{array}$} & \multirow{2}{*}{\begin{tabular}{|c|}
$\begin{array}{c}\mathrm{AN}-107 \\
(\mathrm{Wt} \%)\end{array}$ \\
- \\
\end{tabular}} & \multirow{2}{*}{\begin{tabular}{|c|}
$\begin{array}{c}\mathrm{AN}-107(\mathrm{Wt} \% \\
\text { in glass) }\end{array}$ \\
$25.90 \%$ \\
\end{tabular}} & Source in Simulant & $\begin{array}{l}\text { Order for } \\
\text { Addition }\end{array}$ & Formula Weight & Assay* & Target Weight (g) \\
\hline & $\mathrm{mg} / \mathrm{L}$ & $\mathrm{M}$ & & & & \multicolumn{5}{|c|}{ In $560 \mathrm{ml}$ water add following compounds in the order listed below } \\
\hline & 160 & 0.006 & $\mathrm{Al}_{2} \mathrm{O}_{3}$ & 0.113 & 0.030 & $\mathrm{Al}\left(\mathrm{NO}_{3}\right)_{3} \cdot 9 \mathrm{H}_{2} \mathrm{O}-60 \%$ sol. & 8 & 375.14 & 0.61 & 3.67 \\
\hline $\mathrm{Ca}$ & 353 & 0.009 & $\mathrm{CaO}$ & 0.184 & 0.048 & $\mathrm{Ca}\left(\mathrm{NO}_{3}\right)_{2} * 4 \mathrm{H}_{2} \mathrm{O}$ & 2 & 236.16 & 0.99 & 2.10 \\
\hline $\mathrm{Cr}$ & 103 & 0.002 & $\mathrm{Cr}_{2} \mathrm{O}_{3}$ & 0.056 & 0.015 & $\mathrm{Na}_{2} \mathrm{CrO}_{4} \cdot 4 \mathrm{H}_{2} \mathrm{O}$ & 3 & 234.04 & 0.99 & 0.47 \\
\hline Cs (spike) & 1402 & 0.011 & $\mathrm{Cs}_{2} \mathrm{O}$ & 0.556 & 0.144 & $\mathrm{CsNO}_{3}$ & 4 & 194.91 & 1.00 & 2.06 \\
\hline $\mathrm{Fe}$ & 1070 & 0.019 & $\mathrm{Fe}_{2} \mathrm{O}_{3}$ & 0.572 & 0.148 & $\mathrm{Fe}\left(\mathrm{NO}_{3}\right)_{3} * 9 \mathrm{H}_{2} \mathrm{O}$ & 5 & 404.01 & 1.00 & 7.75 \\
\hline $\mathrm{K}$ & 980 & 0.025 & $\mathrm{~K}_{2} \mathrm{O}$ & 0.441 & 0.114 & $\mathrm{KOH}$ & 7 & 56.10 & 0.91 & 1.55 \\
\hline $\mathrm{Mn}$ & 374 & 0.007 & $\mathrm{MnO}_{2}$ & 0.221 & 0.057 & $\mathrm{MnO}_{2}$ & 15 & 86.97 & 0.99 & 0.59 \\
\hline $\mathrm{Na}$ & 183920 & 8.000 & $\mathrm{Na}_{2} \mathrm{O}$ & 92. 671 & 24.00 & $\mathrm{NaOH}-50 \%$ sol. $d=1.53$ & 6 & 40.00 & 0.50 & 327.96 \\
\hline $\mathrm{Ni}$ & 339 & 0.006 & $\mathrm{NiO}$ & 0.161 & 0.042 & $\mathrm{NiO}$ & 14 & 74.69 & 1.00 & 0.43 \\
\hline $\mathrm{Cl}$ & 1112 & 0.031 & $\mathrm{Cl}$ & 0.416 & 0.108 & $\mathrm{NaCl}$ & 11 & 58.45 & 0.99 & 1.85 \\
\hline $\mathrm{F}$ & 4870 & 0.256 & $\mathrm{~F}$ & 1.821 & 0.471 & $\mathrm{NaF}$ & 12 & 42.00 & 0.99 & 10.87 \\
\hline $\mathrm{PO}_{4}$ & 3042 & 0.032 & $\mathrm{P}_{2} \mathrm{O}_{5}$ & 0.850 & 0.220 & $\mathrm{Na}_{3} \mathrm{PO}_{4} \cdot 12 \mathrm{H}_{2} \mathrm{O}$ & 10 & 380.12 & 0.99 & 12.30 \\
\hline $\mathrm{SO}_{4}$ & 6222 & 0.065 & $\mathrm{SO}_{3}$ & 1.938 & 0.502 & $\mathrm{Na}_{2} \mathrm{SO}_{4}$ (varied content per run) & 13 & 142.06 & 0.99 & See Table 2.20b \\
\hline $\mathrm{NO}_{2}$ & 41158 & 0.895 & - & - & - & $\mathrm{NaNO}_{2}$ & 25 & 69.00 & 1.00 & 62.05 \\
\hline $\mathrm{NO}_{3}$ & 132583 & 2.138 & - & - & - & $\mathrm{NaNO}_{3}$ & 26 & 84.99 & 0.99 & 175.61 \\
\hline Org. Carbon & 24683 & 2.057 & - & - & - & - & - & - & - & - \\
\hline EDTA & 5855 & - & - & - & - & $\mathrm{Na}_{2}$ EDTA. $2 \mathrm{H}_{2} \mathrm{O}(\mathrm{C} 10)$ & 16 & 372.24 & 0.99 & 7.59 \\
\hline HEDTA & 5855 & - & - & - & - & $\mathrm{Na}_{3} \mathrm{HEDTA}$ (C10) - 41\%sol. & 17 & 344.20 & 0.42 & 17.65 \\
\hline Acetate & 5855 & - & - & - & - & Sodium Acetate (C2) & 18 & 136.08 & 0.99 & 13.62 \\
\hline Formate & 5855 & - & - & - & - & Sodium Formate (C1) & 19 & 68.01 & 0.99 & 8.94 \\
\hline Oxalate & 3253 & - & - & - & - & Sodium Oxalate (C2) & 20 & 134.00 & 0.99 & 5.00 \\
\hline Gluconate & 4879 & - & - & - & - & Sodium Gluconate (C6) & 1 & 218.14 & 0.99 & 5.51 \\
\hline Glycolic & 13012 & - & - & - & - & Glycolic Acid (C2) & 21 & 76.05 & 0.71 & 18.35 \\
\hline NTA & 5205 & - & - & - & - & Nitrilotriacetic Acid (C6) & 22 & 191.14 & 0.98 & 5.31 \\
\hline Citric & 14313 & - & - & - & - & Citric Acid (C6) & 23 & 192.12 & 0.99 & 14.46 \\
\hline Iminodiacetic & 4587 & - & - & - & - & Iminodiacetic Acid (C4) & 24 & 133.10 & 0.98 & 4.68 \\
\hline- & - & - & - & - & - & & Target Glas & & & 1033.00 \\
\hline- & - & & SUM & 100 & 25.90 & Tot & al simulant $v$ & ight & & 1279.66 \\
\hline
\end{tabular}

- Empty data field.

* Assay refers to the purity of the raw material as specified by the vendor. 
Table 2.12. Target and Analyzed Compositions (wt \%) of Four ORPLB Crucible Glasses.

\begin{tabular}{|c|c|c|c|c|c|c|c|c|}
\hline GLASS & \multicolumn{2}{|c|}{ ORPLB1 } & \multicolumn{2}{|c|}{ ORPLB2 } & \multicolumn{2}{|c|}{ ORPLB3 } & \multicolumn{2}{|c|}{ ORPLB4 } \\
\hline Oxides & Target & Analyzed ${ }^{*}$ & Target & Analyzed ${ }^{*}$ & Target & Analyzed ${ }^{*}$ & Target & Analyzed $^{*}$ \\
\hline $\mathrm{Al}_{2} \mathrm{O}_{3}$ & 12.00 & 11.82 & 10.00 & 9.91 & 9.88 & 9.89 & 10.03 & 9.85 \\
\hline $\mathrm{B}_{2} \mathrm{O}_{3}$ & 7.30 & 7.54 & 7.30 & 8.07 & 8.57 & 8.70 & 8.52 & 8.29 \\
\hline $\mathrm{CaO}$ & 1.10 & 1.20 & 1.10 & 1.30 & 3.00 & 3.11 & 1.90 & 1.92 \\
\hline $\mathrm{Cr}_{2} \mathrm{O}_{3}$ & 0.52 & 0.66 & 0.52 & 0.67 & 0.53 & 0.67 & 0.53 & 0.70 \\
\hline $\mathrm{Cs}_{2} \mathrm{O}$ (spike) & 0.15 & 0.16 & 0.15 & 0.17 & 0.14 & 0.17 & 0.14 & 0.17 \\
\hline $\mathrm{Fe}_{2} \mathrm{O}_{3}$ & 1.10 & 1.15 & 1.10 & 1.19 & 0.96 & 1.00 & 0.96 & 1.03 \\
\hline $\mathrm{K}_{2} \mathrm{O}$ & 0.12 & 0.14 & 0.12 & 0.18 & 0.11 & 0.14 & 0.11 & 0.15 \\
\hline $\mathrm{MgO}$ & 1.10 & 1.17 & 1.10 & 1.18 & 0.93 & 0.85 & 0.93 & 0.85 \\
\hline $\mathrm{MnO}$ & 0.06 & 0.06 & 0.06 & 0.00 & 0.06 & 0.06 & 0.06 & 0.06 \\
\hline $\mathrm{Na}_{2} \mathrm{O}$ & 25.00 & 24.93 & 25.00 & 24.64 & 24.00 & 23.05 & 24.00 & 23.34 \\
\hline $\mathrm{NiO}$ & 0.04 & 0.04 & 0.04 & 0.12 & 0.04 & 0.05 & 0.04 & 0.04 \\
\hline $\mathrm{SiO}_{2}$ & 37.98 & 38.16 & 39.98 & 39.68 & 40.06 & 40.86 & 40.06 & 40.28 \\
\hline $\mathrm{SnO}_{2}$ & 1.08 & 1.17 & 1.08 & 1.23 & 1.00 & 1.14 & 1.00 & 1.21 \\
\hline $\mathrm{TiO}_{2}$ & 0.00 & 0.02 & 0.00 & 0.02 & 0.00 & 0.01 & 0.00 & 0.02 \\
\hline $\mathrm{V}_{2} \mathrm{O}_{5}$ & 2.00 & 2.20 & 2.00 & 2.24 & 1.00 & 1.11 & 2.00 & 2.24 \\
\hline $\mathrm{ZnO}$ & 3.65 & 3.72 & 3.65 & 3.86 & 2.37 & 2.44 & 2.37 & 2.52 \\
\hline $\mathrm{ZrO}_{2}$ & 5.44 & 5.05 & 5.44 & 5.34 & 6.04 & 5.78 & 6.04 & 6.06 \\
\hline $\mathrm{Cl}$ & 0.11 & 0.10 & 0.11 & 0.10 & 0.11 & 0.10 & 0.11 & 0.10 \\
\hline $\mathrm{F}$ & 0.49 & NA & 0.49 & NA & 0.47 & NA & 0.47 & NA \\
\hline $\mathrm{P}_{2} \mathrm{O}_{5}$ & 0.23 & 0.27 & 0.23 & 0.28 & 0.22 & 0.25 & 0.22 & 0.25 \\
\hline $\mathrm{SO}_{3}$ & 0.52 & 0.48 & 0.52 & 0.48 & 0.50 & 0.47 & 0.50 & 0.45 \\
\hline SUM & 100.0 & 100.5 & 100.0 & 101.2 & 100.0 & 100.3 & 100.0 & 100.0 \\
\hline
\end{tabular}

* - Analyzed by X-ray fluorescence except for boron which was measured by DCP

NA - Not analyzed 
Table 2.13. Descriptions of Four As-Melted and Heat Treated ORPLB Crucible Glasses.

\begin{tabular}{|c|c|c|}
\hline Glass ID & As-melted glass & $\begin{array}{l}\text { Glass remelted at } 1200^{\circ} \mathrm{C} \text { for } 1 \text { hour, heat } \\
\text { treated for } 20 \text { hours at } 950^{\circ} \mathrm{C} \text {, and quenched. }\end{array}$ \\
\hline ORPLB1 & Clear glass & $\begin{array}{c}0.1 \text { to } 0.2 \text { vol\% of Cr-rich spinel with Zn, Al, } \\
\text { and Sn. }\end{array}$ \\
\hline ORPLB2 & Clear glass & $\begin{array}{c}0.1 \text { to } 0.2 \text { vol\% of Cr-rich spinel with Zn, Al, } \\
\text { and Sn. }\end{array}$ \\
\hline ORPLB3 & Clear glass & $\begin{array}{l}<0.1 \text { vol\% of Cr-rich spinel with } \mathrm{Zn}, \mathrm{Al} \text {, and } \\
\text { Sn. }\end{array}$ \\
\hline ORPLB4 & $\begin{array}{c}\text { Clear glass. }<0.1 \text { vol\% of small } \mathrm{Cr}+\mathrm{Zn} \\
\text { crystals }\end{array}$ & $\begin{array}{l}<0.1 \text { vol\% of Cr-rich spinel with Zn, Al, and } \\
\text { Sn. }\end{array}$ \\
\hline
\end{tabular}

Table 2.14. Measured Sulfate Solubility Limits in Four ORPLB Crucible Glasses.

\begin{tabular}{|c|c|c|c|}
\hline \multirow{2}{*}{ Sample ID } & \multicolumn{3}{|c|}{ SO $_{3}$ Content (wt\%) (Target Minimum $=0.2$ to $\left.0.5 \mathrm{wt} \%\right)$} \\
\cline { 2 - 3 } & \multicolumn{2}{|c|}{ Batch Saturation } & \multirow{2}{*}{ Bubbling* } \\
\cline { 2 - 3 } & As-Melted & After Acid Wash & \\
\hline ORPLB1S4 & 0.59 & 0.56 & 0.62 \\
\hline ORPLB2S4 & 0.60 & 0.58 & 0.68 \\
\hline ORPLB3S4 & 0.55 & 0.54 & - \\
\hline ORPLB4S4 & 0.53 & 0.52 & 0.70 \\
\hline
\end{tabular}

"-" Empty data field

* Starting glass for bubbling tests contained no $\mathrm{SO}_{3}$. 
ORP-56293 Rev. 0

Vitreous State Laboratory

The Catholic University of America

Table 2.15. Results of 7-day PCT (at $90^{\circ} \mathrm{C}$ ) and VHT (at $200^{\circ} \mathrm{C}$ for 24 Days) for Four ORPLB Crucible Glasses.

\begin{tabular}{|c|c|c|c|c|}
\hline Glass ID & ORPLB1 & ORPLB2 & ORPLB3 & ORPLB4 \\
\hline \multicolumn{5}{|c|}{ 7-Day PCT, Stainless Steel Vessel; S/V=2000m ${ }^{-1} \quad$ (ppm) } \\
\hline $\mathrm{B}$ & 27.45 & 38.24 & 29.41 & 37.18 \\
\hline $\mathrm{Na}$ & 242.30 & 285.10 & 205.20 & 236.30 \\
\hline $\mathrm{Si}$ & 73.97 & 82.30 & 65.43 & 69.70 \\
\hline \multicolumn{5}{|c|}{ Normalized Concentrations (g/L) } \\
\hline B & 1.21 & 1.69 & 1.10 & 1.41 \\
\hline $\mathrm{Na}$ & 1.31 & 1.54 & 1.15 & 1.33 \\
\hline $\mathrm{Si}$ & 0.42 & 0.44 & 0.35 & 0.37 \\
\hline $\mathrm{pH}$ & 11.65 & 11.74 & 11.46 & 11.53 \\
\hline \multicolumn{5}{|c|}{ 7-Day PCT Normalized Mass Loss $\left(\mathrm{g} / \mathrm{m}^{2}\right)$} \\
\hline $\mathrm{B}$ & 0.61 & 0.84 & 0.55 & 0.70 \\
\hline $\mathrm{Na}$ & 0.65 & 0.77 & 0.58 & 0.66 \\
\hline $\mathrm{Si}$ & 0.21 & 0.22 & 0.17 & 0.19 \\
\hline \multicolumn{5}{|c|}{ 7-Day PCT Normalized Loss Rate $\left(\mathrm{g} / \mathrm{m}^{2} / \mathrm{d}\right)$} \\
\hline $\mathrm{B}$ & 0.09 & 0.12 & 0.08 & 0.10 \\
\hline $\mathrm{Na}$ & 0.09 & 0.11 & 0.08 & 0.09 \\
\hline Si & 0.03 & 0.03 & 0.02 & 0.03 \\
\hline \multicolumn{5}{|c|}{ VHT Alteration $\left(24\right.$ days at $\left.200^{\circ} \mathrm{C}\right)-$ Measurements on ORPLB and ORPLBS4 Samples } \\
\hline Alteration Depth $(\mu \mathrm{m})$ & >> 1200 & 995 & 344 & 369 \\
\hline Alteration Rate $\left(\mathrm{g} / \mathrm{m}^{2} / \text { day }\right)^{*}$ & $>130$ & 110 & 38 & 41 \\
\hline Alteration Depth $(\mu \mathrm{m})$ & $>1175$ & 526 & 797 & 320 \\
\hline Alteration Rate $\left(\mathrm{g} / \mathrm{m}^{2} / \text { day }\right)^{*}$ & $>130$ & 58 & 88 & 35 \\
\hline
\end{tabular}

* Alteration rates calculated using estimated density of $2.65 \mathrm{~g} / \mathrm{cc}$ 
Table 2.16. Viscosities and Electrical Conductivities of Four ORPLB Crucible Glasses.

\begin{tabular}{|c|c|c|c|c|}
\hline $\begin{array}{c}\text { Glass } \\
\text { ID }\end{array}$ & ORPLB1 & ORPLB2 & ORPLB3 & ORPLB4 \\
\hline \multicolumn{5}{|l|}{ Viscosity (poise) } \\
\hline $900^{\circ} \mathrm{C}$ & 2873 & 2668 & 1928 & 2592 \\
\hline $950^{\circ} \mathrm{C}$ & 1157 & 1058 & 821 & 1034 \\
\hline $1000^{\circ} \mathrm{C}$ & 525 & 478 & 388 & 468 \\
\hline $1050^{\circ} \mathrm{C}$ & 263 & 240 & 200 & 235 \\
\hline $1100^{\circ} \mathrm{C}$ & 142 & 131 & 111 & 128 \\
\hline $1150^{\circ} \mathrm{C}$ & 83 & 77 & 65 & 75 \\
\hline $1200^{\circ} \mathrm{C}$ & 51 & 48 & 40 & 46 \\
\hline $1250^{\circ} \mathrm{C}$ & 33 & 31 & 26 & 30 \\
\hline Electrical Conductivity (S/cm) & & \\
\hline $900^{\circ} \mathrm{C}$ & 0.265 & 0.305 & 0.288 & 0.258 \\
\hline $950^{\circ} \mathrm{C}$ & 0.365 & 0.376 & 0.365 & 0.319 \\
\hline $1000^{\circ} \mathrm{C}$ & 0.469 & 0.456 & 0.447 & 0.388 \\
\hline $1050^{\circ} \mathrm{C}$ & 0.573 & 0.546 & 0.533 & 0.466 \\
\hline $1100^{\circ} \mathrm{C}$ & 0.676 & 0.644 & 0.620 & 0.551 \\
\hline $1150^{\circ} \mathrm{C}$ & 0.776 & 0.751 & 0.709 & 0.644 \\
\hline $1200^{\circ} \mathrm{C}$ & 0.873 & 0.867 & 0.799 & 0.744 \\
\hline $1250^{\circ} \mathrm{C}$ & 0.965 & 0.991 & 0.889 & 0.853 \\
\hline
\end{tabular}

Table 2.17. Results of K-3 Corrosion Testing for Four ORPLB Crucible Glasses.

\begin{tabular}{|c|c|c|c|}
\hline Glass ID & $\begin{array}{c}\text { Neck loss } \\
\text { (inches) }\end{array}$ & $\begin{array}{c}\text { Depth of altered } \\
\text { zone (inches) }\end{array}$ & $\begin{array}{c}\text { Half-down loss } \\
\text { (inches) }\end{array}$ \\
\hline ORPLB1 & 0.036 & 0.019 & $\begin{array}{c}\text { Coupon expanded }- \\
\text { no measurable loss }\end{array}$ \\
\hline ORPLB2 & 0.039 & 0.023 & 0.001 \\
\hline ORPLB3 & 0.036 & 0.027 & $\begin{array}{c}\text { Coupon expanded }- \\
\text { no measurable loss }\end{array}$ \\
\hline ORPLB4 & 0.033 & 0.023 & $\begin{array}{c}\text { Coupon expanded }- \\
\text { no measurable loss }\end{array}$ \\
\hline
\end{tabular}


Table 2.18. Summary of Test Results for Selected ORPLB Glass Formulation ORPLB4 and Comparison to ILAW Requirements.

\begin{tabular}{|c|c|c|}
\hline Test & Requirement $[45,46]$ & $\begin{array}{l}\text { Test Result for } \\
\text { ORPLB4 }\end{array}$ \\
\hline Density of glass & $<3.7 \mathrm{~g} / \mathrm{cc}$ & Not measured \\
\hline Crystalline Phase & Phase identification & $\begin{array}{l}\text { Clear homogeneous glass } \\
\text { with less than } 0.1 \text { vol\% crystals after } \\
\text { heat treatment at } 950^{\circ} \mathrm{C} \text { for } 20 \text { hours }\end{array}$ \\
\hline Liquidus & $<950^{\circ} \mathrm{C}$ & $<950^{\circ} \mathrm{C}$ \\
\hline Centerline Canister Cooling & Phase identification & Not measured \\
\hline PCT B $\left(\mathrm{g} / \mathrm{m}^{2}\right)$ & $<2.0 \mathrm{~g} / \mathrm{m}^{2}$ & $0.70 \mathrm{~g} / \mathrm{m}^{2}$ \\
\hline PCT Na $\left(g / m^{2}\right)$ & $<2.0 \mathrm{~g} / \mathrm{m}^{2}$ & $0.66 \mathrm{~g} / \mathrm{m}^{2}$ \\
\hline PCT Si $\left(g / m^{2}\right)$ & $<2.0 \mathrm{~g} / \mathrm{m}^{2}$ & $0.19 \mathrm{~g} / \mathrm{m}^{2}$ \\
\hline VHT at $200^{\circ} \mathrm{C}\left(\mathrm{g} / \mathrm{m}^{2} /\right.$ day $)$ & $<50 \mathrm{~g} / \mathrm{m}^{2} /$ day & $\begin{array}{c}35 \text { and } 41 \mathrm{~g} / \mathrm{m}^{2} / \text { day } \\
\text { (measurements on ORPLB and } \\
\text { ORPLBS4 samples) }\end{array}$ \\
\hline Viscosity (poise) at $1100^{\circ} \mathrm{C}$ & 10 to $150 \mathrm{P}$ & $128 \mathrm{P}$ \\
\hline Conductivity $(\mathrm{S} / \mathrm{cm})$ at $1100^{\circ} \mathrm{C}$ & 0.2 to $0.7 \mathrm{~S} / \mathrm{cm}$ & $0.551 \mathrm{~S} / \mathrm{cm}$ \\
\hline $\mathrm{T}_{\mathrm{G}}\left({ }^{\circ} \mathrm{C}\right)$ & Report for modeling & Not measured \\
\hline
\end{tabular}


Table 2.19. Oxide Composition of AN-107 Simulant and ORPLB4 Glass Composition Used in Melter Tests (wt\%).

\begin{tabular}{|c|c|c|c|}
\hline Component & AN-107 waste contribution & $\begin{array}{c}\text { Glass former } \\
\text { additives }\end{array}$ & $\begin{array}{c}\text { ORPLB4 } \\
\text { (for AN-107) }\end{array}$ \\
\hline Loading & $26.2 \%$ & $73.8 \%$ & - \\
\hline $\mathrm{Al}_{2} \mathrm{O}_{3}$ & 0.028 & 9.95 & 9.98 \\
\hline $\mathrm{B}_{2} \mathrm{O}_{3}$ & - & 8.48 & 8.48 \\
\hline $\mathrm{CaO}$ & 0.046 & 1.84 & 1.89 \\
\hline $\mathrm{Cr}_{2} \mathrm{O}_{3}$ & 0.014 & 0.51 & 0.52 \\
\hline $\mathrm{Cs}_{2} \mathrm{O}$ & 0.137 & - & 0.14 \\
\hline $\mathrm{Fe}_{2} \mathrm{O}_{3}$ & 0.141 & 0.82 & 0.96 \\
\hline $\mathrm{K}_{2} \mathrm{O}$ & 0.109 & - & 0.11 \\
\hline $\mathrm{MgO}$ & - & 0.93 & 0.93 \\
\hline $\mathrm{MnO}_{2}$ & 0.055 & - & 0.05 \\
\hline $\mathrm{Na}_{2} \mathrm{O}^{(\mathrm{a})}$ & $22.885+0.658^{(1)}+0.457^{(2)}$ & - & 24.00 \\
\hline $\mathrm{NiO}$ & 0.040 & - & 0.04 \\
\hline $\mathrm{SiO}_{2}$ & - & 39.88 & 39.88 \\
\hline $\mathrm{SnO}_{2}$ & - & 1.00 & 1.00 \\
\hline $\mathrm{V}_{2} \mathrm{O}_{5}$ & - & 1.99 & 1.99 \\
\hline $\mathrm{ZnO}$ & - & 2.36 & 2.36 \\
\hline $\mathrm{ZrO}_{2}$ & - & 6.02 & 6.02 \\
\hline $\mathrm{Cl}$ & 0.108 & - & 0.11 \\
\hline $\mathrm{F}$ & 0.471 & - & 0.47 \\
\hline $\mathrm{P}_{2} \mathrm{O}_{5}$ & 0.220 & - & 0.22 \\
\hline $\mathrm{SO}_{3}{ }^{(b)}$ & $0.85^{(1)}$ & - & 0.85 \\
\hline SUM & 26.2 & 73.8 & 100.0 \\
\hline
\end{tabular}

(a) Simulant was ordered at a concentration of $22.89 \mathrm{wt} \% \mathrm{Na}_{2} \mathrm{O}$ and modified before each melter test with (1) $\mathrm{Na}_{2} \mathrm{SO}_{4}$ and (2) $\mathrm{NaOH}$ additions to obtain $24 \mathrm{wt} \% \mathrm{Na}_{2} \mathrm{O}$ in the glass.

(b) Concentration of $\mathrm{SO}_{3}$ was increased in steps during the melter tests from $0.6 \mathrm{wt} \% \mathrm{SO}_{3}$ in the glass up to $1.0 \mathrm{wt} \%$.

- Empty data field 
Table 2.20a. Glass Former Additives for 1 Liter of AN-107 Simulant (8 M Na) and Corresponding Melter Feed Properties.

\begin{tabular}{|c|c|}
\hline Additives Source & Feed ORPLB4 \\
\hline Additives in Glass (wt\%) & 73.78 \\
\hline Kyanite $\left(\mathrm{Al}_{2} \mathrm{SiO}_{5}\right) 325$ Mesh (Kyanite Mining) (g) & 181.47 \\
\hline $\mathrm{H}_{3} \mathrm{BO}_{3}$ (US Borax - Technical Granular) (g) & 156.33 \\
\hline Wollanstonite NYAD 325 Mesh (NYCO Minerals) (g) & 42.10 \\
\hline $\mathrm{Cr}_{2} \mathrm{O}_{3}$ oxide & $5.33^{(1)}$ \\
\hline $\mathrm{Fe}_{2} \mathrm{O}_{3}$ (Prince Manufacturing) (g) & 5.94 \\
\hline Olivine $\left(\mathrm{Mg}_{2} \mathrm{SiO}_{4}\right) 325$ Mesh (\#180 Unimin) (g) & 19.49 \\
\hline $\mathrm{SiO}_{2}$ (Sil-co-Sil 75 US Silica) (g) & 275.73 \\
\hline SnO2 - Stannous Oxide - Mason color & 10.34 \\
\hline $\mathrm{V}_{2} \mathrm{O}_{5}$ - Pulva Ground - Stratcor & 20.67 \\
\hline ZnO (KADOX - 920 Zinc Corp. of America) (g) & 24.48 \\
\hline Zircon $\mathrm{ZrSiO}_{4}$ (Flour) Mesh 325 (AM. Mineral) (g) & 94.11 \\
\hline Supplemental $\mathrm{Na}_{2} \mathrm{SO}_{4}$ & Variable - Table 2.20b \\
\hline Addition of Sucrose as Reductant (g) & 6.21 \\
\hline Simulant Weight for 1 liter (g) & 1279.66 \\
\hline Sum of Additives (g) & 936 \\
\hline Sum of Complete Batch (g) & 2116 \\
\hline Target Final Volume (l) & 1.24 \\
\hline Estimated Density (g/ml) & 1.70 \\
\hline Target Glass Produced (g) & 1033 \\
\hline Target Weight \% Additives in Slurry & 40 \\
\hline Target Glass Yield (g/kg of Feed) & 488 \\
\hline Target Glass Yield (g/l of Feed) & 830 \\
\hline Target Total Solids ( $\mathrm{g} / \mathrm{l}$ of Feed) & 1117 \\
\hline Target Additives ( $\mathrm{g} / \mathrm{l}$ of Feed) & 672 \\
\hline
\end{tabular}

${ }^{(1)}$ Note that a $\mathrm{Cr}_{2} \mathrm{O}_{3}$ addition was cut down by $50 \%$ to account for K3-brick contribution.

Table 2.20b. $\mathrm{NaOH}$ and $\mathrm{Na}_{2} \mathrm{SO}_{4}$ Additions Required to Obtain $24 \mathrm{wt} \% \mathrm{Na}_{2} \mathrm{O}$ and Various $\mathrm{SO}_{3}$ Concentrations Ranging from 0.6 to $1.0 \mathrm{wt} \%$ in the ORPLB4 Glass.

\begin{tabular}{|c|c|c|}
\hline $\begin{array}{c}\text { Final } \\
\mathrm{SO}_{3} \mathrm{wt} \%\end{array}$ & $\begin{array}{c}\text { NaOH needed } \\
\text { per kg of feed } \\
\text { (grams) }\end{array}$ & $\begin{array}{c}\mathrm{Na}_{2} \mathrm{SO}_{4} \text { needed } \\
\text { per kg of feed } \\
\text { (grams) }\end{array}$ \\
\hline 0.6 & 8.31 & 5.31 \\
\hline 0.7 & 7.32 & 6.22 \\
\hline 0.8 & 6.33 & 7.11 \\
\hline 0.85 & 5.84 & 7.56 \\
\hline 0.9 & 5.34 & 8.00 \\
\hline 1.0 & 4.35 & 8.89 \\
\hline
\end{tabular}


Table 2.21. LAW Sub-Envelope A3 (AN-104) Waste Simulant Recipe at 8 Molar Sodium.

\begin{tabular}{|c|c|c|c|c|c|c|c|c|c|c|}
\hline \multirow{3}{*}{$\begin{array}{c}\begin{array}{c}\text { Envelope } \\
\text { Constituents }\end{array} \\
- \\
\mathrm{Al} \\
\end{array}$} & \multicolumn{2}{|c|}{$\begin{array}{c}\text { Simulant AN-104 } \\
\text { Including Pretreatment }\end{array}$} & \multirow{2}{*}{$\begin{array}{c}\text { Glass } \\
\text { Oxides } \\
\text { Loading } \\
\end{array}$} & \multirow{2}{*}{$\begin{array}{c}\text { LAW A3 } \\
\text { Simulant as } \\
\text { Oxides (wt\%) } \\
-\end{array}$} & \multirow{2}{*}{$\begin{array}{c}\begin{array}{c}\text { Waste } \\
\text { Contribution } \\
\text { to } \\
\text { Glass }\end{array} \\
18.84 \% \\
\end{array}$} & \multirow[t]{2}{*}{ Source in Simulant } & \multirow[t]{2}{*}{$\begin{array}{l}\text { Order for } \\
\text { Addition }\end{array}$} & \multirow[t]{2}{*}{$\begin{array}{c}\text { Formula } \\
\text { Weight }\end{array}$} & \multirow{2}{*}{$\begin{array}{l}\text { Assay* } \\
\text { listed belo }\end{array}$} & \multirow[t]{2}{*}{$\begin{array}{c}\text { Target } \\
\text { Weight (g) }\end{array}$} \\
\hline & $\mathrm{mg} / \mathrm{L}$ & Molarity & & & & & & & & \\
\hline & 28650 & 1.062 & $\mathrm{Al}_{2} \mathrm{O}_{3}$ & 16.700 & 5.147 & $\mathrm{Al}\left(\mathrm{NO}_{3}\right)_{3} \cdot 9 \mathrm{H}_{2} \mathrm{O}, 60 \%$ sol. & 1 & 375.14 & 0.61 & 469.55 \\
\hline - & - & - & - & - & - & $\mathrm{Al}(\mathrm{OH})_{3}$ & 4 & 78.00 & 1.00 & 23.67 \\
\hline $\mathrm{Cr}$ & 248 & 0.005 & $\mathrm{Cr}_{2} \mathrm{O}_{3}$ & 0.112 & 0.034 & $\mathrm{Na}_{2} \mathrm{CrO}_{4} * 4 \mathrm{H}_{2} \mathrm{O}$ & 7 & 234.04 & 0.99 & 1.13 \\
\hline Cs spike & 1402 & 0.011 & $\mathrm{Cs}_{2} \mathrm{O}$ & 0.458 & 0.141 & $\mathrm{CsNO}_{3}$ & 2 & 194.91 & 1.00 & 2.06 \\
\hline $\mathrm{K}$ & 4737 & 0.121 & $\mathrm{~K}_{2} \mathrm{O}$ & 1.760 & 0.543 & $\mathrm{KOH}$ & 6 & 56.10 & 0.91 & 7.49 \\
\hline $\mathrm{Na}$ & 183920 & 8.000 & $\mathrm{Na}_{2} \mathrm{O}$ & 76.479 & 23.57 & $\mathrm{NaOH}, 50 \%$ sol. $d=1.53$ & 5 & 40.00 & 0.50 & 341.04 \\
\hline $\mathrm{Si}$ & 260 & 0.009 & $\mathrm{SiO}_{2}$ & 0.172 & 0.053 & $\mathrm{SiO}_{2}$ & 3 & 60.09 & 0.99 & 0.56 \\
\hline $\mathrm{Cl}$ & 6499 & 0.183 & $\mathrm{Cl}$ & 2.005 & 0.618 & $\mathrm{NaCl}$ & 9 & 58.45 & 0.99 & 10.82 \\
\hline $\mathrm{F}$ & 84 & 0.004 & $\mathrm{~F}$ & 0.026 & 0.008 & $\mathrm{NaF}$ & 10 & 42.00 & 0.99 & 0.19 \\
\hline $\mathrm{PO}_{4}$ & 2607 & 0.027 & $\mathrm{P}_{2} \mathrm{O}_{5}$ & 0.601 & 0.185 & $\mathrm{Na}_{3} \mathrm{PO}_{4} \cdot 12 \mathrm{H}_{2} \mathrm{O}$ & 8 & 380.12 & 0.99 & 10.54 \\
\hline $\mathrm{SO}_{4}$ (Nominal) & 6561 & 0.068 & $\mathrm{SO}_{3}$ & 1.687 & 0.520 & $\begin{array}{c}\mathrm{Na}_{2} \mathrm{SO}_{4} \text { (varied content per } \\
\text { run) }\end{array}$ & 11 & 142.06 & 0.99 & $\begin{array}{c}\text { See Table } \\
\text { 2.30b }\end{array}$ \\
\hline $\mathrm{NO}_{2}$ & 89867 & 1.954 & $\mathrm{NO}_{2}$ & 一 & 一 & $\mathrm{NaNO}_{2}$ & 14 & 69.00 & 1.00 & 135.48 \\
\hline $\mathrm{NO}_{3}$ & 141946 & 2.289 & $\mathrm{NO}_{3}$ & 一 & 一 & $\mathrm{NaNO}_{3}$ & & 84.99 & 0.99 & 0.00 \\
\hline $\mathrm{CO}_{3}$ & 36182 & 0.603 & $\mathrm{CO}_{3}$ & - & 一 & $\mathrm{Na}_{2} \mathrm{CO}_{3}$ & 15 & 105.99 & 1.00 & 63.91 \\
\hline Org.Carbon & 2339 & 0.195 & - & - & - & - & - & - & - & - \\
\hline Acetate & 2611 & 0.044 & 一 & 一 & 一 & Sodium Acetate (C2) & 12 & 136.08 & 0.99 & 6.08 \\
\hline Formate & 4772 & 0.106 & - & 一 & - & Sodium Formate (C1) & 13 & 68.01 & 0.99 & 7.28 \\
\hline 一 & 一 & 一 & 一 & 一 & 一 & & Glass Weig & & & 1051.85 \\
\hline 一 & 一 & 一 & SUM & 100.00 & 18.839 & & mulant We & & & 1389.59 \\
\hline
\end{tabular}

- Empty data field.

* Assay refers to the purity of the raw material as specified by the vendor. 
Table 2.22. Target and Analyzed Compositions (wt\%) of Five ORPLC Crucible Glasses.

\begin{tabular}{|c|c|c|c|c|c|c|c|c|c|c|}
\hline \multirow{2}{*}{$\begin{array}{l}\text { GLASS } \\
\text { Oxides }\end{array}$} & \multicolumn{2}{|c|}{ ORPLC1 } & \multicolumn{2}{|c|}{ ORPLC2 } & \multicolumn{2}{|c|}{ ORPLC3 } & \multicolumn{2}{|c|}{ ORPLC4 } & \multicolumn{2}{|c|}{ ORPLC5 } \\
\hline & Target & Analyzed $^{*}$ & Target & Analyzed ${ }^{*}$ & Target & Analyzed* & Target & Analyzed ${ }^{*}$ & Target & Analyzed ${ }^{*}$ \\
\hline $\mathrm{Al}_{2} \mathrm{O}_{3}$ & 9.50 & 9.52 & 10.67 & 10.53 & 10.67 & 10.30 & 10.65 & 10.28 & 10.04 & 9.17 \\
\hline $\mathrm{B}_{2} \mathrm{O}_{3}$ & 6.06 & 6.16 & 11.67 & NA & 11.67 & NA & 11.19 & NA & 8.52 & 8.07 \\
\hline $\mathrm{CaO}$ & 3.00 & 3.16 & 6.42 & 6.52 & 4.11 & 4.45 & 6.47 & 6.76 & 1.91 & 1.92 \\
\hline $\mathrm{Cr}_{2} \mathrm{O}_{3}$ & 0.50 & 0.66 & 0.51 & 0.65 & 0.51 & 0.69 & 0.51 & 0.68 & 0.53 & 0.66 \\
\hline $\mathrm{Cs}_{2} \mathrm{O}$ (spike) & 0.15 & 0.15 & 0.14 & 0.13 & 0.14 & 0.13 & 0.14 & 0.16 & 0.14 & 0.17 \\
\hline $\mathrm{Fe}_{2} \mathrm{O}_{3}$ & 1.00 & 1.11 & 0.90 & 0.93 & 0.90 & 0.99 & 0.91 & 1.00 & 0.97 & 0.96 \\
\hline $\mathrm{K}_{2} \mathrm{O}$ & 0.58 & 0.63 & 0.54 & 0.52 & 0.54 & 0.56 & 0.54 & 0.55 & 0.54 & 0.52 \\
\hline $\mathrm{MgO}$ & 1.00 & 0.96 & 0.90 & 0.81 & 0.90 & 0.82 & 0.91 & 0.86 & 0.93 & 0.98 \\
\hline $\mathrm{Na}_{2} \mathrm{O}$ & 25.00 & 23.88 & 23.50 & 23.01 & 23.50 & 22.02 & 23.50 & 22.45 & 23.57 & 23.92 \\
\hline $\mathrm{SiO}_{2}$ & 38.32 & 37.61 & 34.52 & 35.08 & 34.52 & 34.88 & 34.86 & 34.92 & 40.10 & 40.46 \\
\hline $\mathrm{SnO}_{2}$ & 2.00 & 2.36 & 0.99 & 1.02 & 0.99 & 1.05 & 1.00 & 1.20 & 1.00 & 1.14 \\
\hline $\mathrm{TiO}_{2}$ & 1.00 & 1.11 & 0.00 & 0.02 & 0.00 & 0.01 & 0.00 & 0.01 & 0.00 & 0.01 \\
\hline $\mathrm{V}_{2} \mathrm{O}_{5}$ & 3.00 & 3.46 & 1.47 & 1.61 & 1.47 & 1.71 & 1.48 & 1.70 & 2.00 & 2.12 \\
\hline $\mathrm{ZnO}$ & 3.00 & 3.24 & 2.97 & 3.02 & 2.97 & 3.29 & 3.00 & 3.22 & 2.37 & 2.36 \\
\hline $\mathrm{ZrO}_{2}$ & 4.50 & 4.51 & 3.46 & 3.15 & 3.46 & 3.43 & 3.50 & 3.53 & 6.04 & 5.53 \\
\hline $\mathrm{Cl}$ & 0.66 & 0.59 & 0.62 & 0.54 & 0.62 & 0.59 & 0.62 & 0.60 & 0.62 & 0.64 \\
\hline $\mathrm{F}$ & 0.01 & NA & 0.01 & NA & 0.01 & NA & 0.01 & NA & 0.01 & NA \\
\hline $\mathrm{P}_{2} \mathrm{O}_{5}$ & 0.20 & 0.25 & 0.18 & 0.20 & 2.50 & 2.69 & 0.18 & 0.22 & 0.19 & 0.22 \\
\hline $\mathrm{SO}_{3}$ & 0.55 & 0.50 & 0.52 & 0.49 & 0.52 & 0.52 & 0.52 & 0.51 & 0.52 & 0.48 \\
\hline SUM & 100.0 & 99.9 & 100.0 & 99.9 & 100.0 & 99.8 & 100.0 & 99.8 & 100.0 & 99.4 \\
\hline
\end{tabular}

* - Analyzed by X-ray fluorescence except for boron which was measured by DCP

NA - Not analyzed 
Table 2.23. Descriptions of Five As-Melted and Heat Treated ORPLC Crucible Glasses.

\begin{tabular}{|c|c|c|}
\hline Glass ID & As-melted glass & $\begin{array}{l}\text { Glass remelted at } 1200^{\circ} \mathrm{C} \text { for } 1 \text { hour, heat } \\
\text { treated for } 20 \text { hours at } 950^{\circ} \mathrm{C} \text {, and quenched. }\end{array}$ \\
\hline ORPLC1 & $\begin{array}{c}\text { Clear glass. }<<0.1 \mathrm{vol} \% \text { of small } \mathrm{Cr} \\
\text { crystals }\end{array}$ & $\begin{array}{c}\sim 0.1 \text { to } 0.3 \text { vol\% sodalite (Na,Al-silicate } \\
\text { sulfate) and Cr crystals }\end{array}$ \\
\hline ORPLC2 & $\begin{array}{c}\text { Clear glass. }<<0.1 \text { vol\% of small } \mathrm{Cr}+\mathrm{Zn} \\
\text { crystals }\end{array}$ & Clear glass \\
\hline ORPLC3 & $\begin{array}{c}\text { Clear glass. }<<0.1 \text { vol\% of small } \mathrm{Cr}+\mathrm{Zn} \\
\text { crystals }\end{array}$ & Clear glass \\
\hline ORPLC4 & $\begin{array}{c}\text { Clear glass. }<<0.1 \text { vol\% of small } \mathrm{Cr}+\mathrm{Zn} \\
\text { crystals }\end{array}$ & Clear glass \\
\hline ORPLC5 & $\begin{array}{c}\text { Clear glass. }<<0.1 \text { vol\% of small } \mathrm{Cr} \\
\text { crystals }\end{array}$ & Clear glass. $<<0.1$ vol\% of small Cr crystals \\
\hline
\end{tabular}

Table 2.24. Measured Sulfate Solubility Limits in Five ORPLC Crucible Glasses.

\begin{tabular}{|c|c|c|c|}
\hline \multirow{2}{*}{ Sample ID } & \multicolumn{3}{|c|}{ SO3 Content (wt \%) (Target Minimum = 0.45 to 0.75 wt\%) } \\
\cline { 2 - 3 } & \multicolumn{2}{|c|}{ Batch Saturation } & \multirow{2}{*}{ Bubbling* } \\
\cline { 2 - 3 } & As-Melted & After Acid Wash & \\
\hline ORPLC1S4 & 0.62 & 0.59 & 0.58 \\
\hline ORPLC2S4 & 0.74 & 0.68 & - \\
\hline ORPLC3S4 & 0.70 & 0.63 & - \\
\hline ORPLC4S4 & 0.77 & 0.70 & 1.09 \\
\hline ORPLC5S4 & 0.57 & 0.56 & - \\
\hline
\end{tabular}

- Empty data field

* Starting glass for bubbling tests contained no $\mathrm{SO}_{3}$. 
ORP-56293 Rev. 0

Vitreous State Laboratory

The Catholic University of America

Table 2.25. Results of 7-day PCT (at $90^{\circ} \mathrm{C}$ ) and VHT (at $200^{\circ} \mathrm{C}$ for 24 Days) for Five ORPLC Crucible Glasses.

\begin{tabular}{|c|c|c|c|c|c|}
\hline Glass ID & ORPLC1 & ORPLC2 & ORPLC3 & ORPLC4 & ORPLC5 \\
\hline \multicolumn{6}{|c|}{ 7-Day PCT, Stainless Steel Vessel; S/V=2000m ${ }^{-1} \quad(p p m)$} \\
\hline $\mathrm{B}$ & - & 81.20 & 126.30 & 72.72 & 44.97 \\
\hline $\mathrm{Na}$ & - & 392.20 & 446.30 & 359.60 & 260.5 \\
\hline $\mathrm{Si}$ & - & 73.28 & 68.20 & 71.01 & 67.71 \\
\hline \multicolumn{6}{|c|}{ Normalized Concentrations (g/L) } \\
\hline B & - & 2.24 & 3.48 & 2.09 & 1.70 \\
\hline $\mathrm{Na}$ & - & 2.25 & 2.56 & 2.06 & 1.49 \\
\hline $\mathrm{Si}$ & - & 0.45 & 0.42 & 0.44 & 0.36 \\
\hline $\mathrm{pH}$ & - & 11.77 & 11.61 & 11.75 & 11.38 \\
\hline \multicolumn{6}{|c|}{ 7-Day PCT Normalized Mass Loss $\left(\mathrm{g} / \mathrm{m}^{2}\right)$} \\
\hline $\mathrm{B}$ & - & 1.12 & 1.74 & 1.05 & 0.85 \\
\hline $\mathrm{Na}$ & - & 1.12 & 1.28 & 1.03 & 0.74 \\
\hline $\mathrm{Si}$ & - & 0.23 & 0.21 & 0.22 & 0.18 \\
\hline \multicolumn{6}{|c|}{ 7-Day PCT Normalized Loss Rate $\left(\mathrm{g} / \mathrm{m}^{2} / \mathrm{d}\right)$} \\
\hline $\mathrm{B}$ & - & 0.16 & 0.25 & 0.15 & 0.12 \\
\hline $\mathrm{Na}$ & - & 0.16 & 0.18 & 0.15 & 0.11 \\
\hline $\mathrm{Si}$ & - & 0.03 & 0.03 & 0.03 & 0.03 \\
\hline \multicolumn{6}{|c|}{ VHT Alteration (24 days at $\left.200^{\circ} \mathrm{C}\right)-$ Measurements on ORPLC and ORPLCS4 Samples } \\
\hline Alteration Depth $(\mu \mathrm{m})$ & 1116 & >> 1200 & >> 1200 & $>>1200$ & 362 \\
\hline Alteration Rate $\left(\mathrm{g} / \mathrm{m}^{2} / \text { day }\right)^{*}$ & 123 & $>130$ & $>>130$ & $>130$ & 40 \\
\hline Alteration Depth $(\mu \mathrm{m})$ & 1066 & 753 & >> 1200 & >> 1200 & 224 \\
\hline Alteration Rate $\left(\mathrm{g} / \mathrm{m}^{2} / \text { day }\right)^{*}$ & 118 & 83 & >> 130 & $>130$ & 25 \\
\hline
\end{tabular}

* Alteration rates calculated using estimated density of $2.65 \mathrm{~g} / \mathrm{cc}$ 
Table 2.26. Viscosities and Electrical Conductivities of Three ORPLC Crucible Glasses.

\begin{tabular}{|c|c|c|c|}
\hline $\begin{array}{c}\text { Glass } \\
\text { ID }\end{array}$ & ORPLC1 & ORPLC2 & ORPLC5 \\
\hline \multicolumn{3}{|l|}{ Viscosity (poise) } \\
\hline $900^{\circ} \mathrm{C}$ & 2489 & 546 & 3159 \\
\hline $950^{\circ} \mathrm{C}$ & 883 & 245 & 1152 \\
\hline $1000^{\circ} \mathrm{C}$ & 376 & 124 & 493 \\
\hline $1050^{\circ} \mathrm{C}$ & 184 & 69 & 239 \\
\hline $1100^{\circ} \mathrm{C}$ & 100 & 42 & 128 \\
\hline $1150^{\circ} \mathrm{C}$ & 59 & 27 & 74 \\
\hline $1200^{\circ} \mathrm{C}$ & 37 & 18 & 46 \\
\hline $1250^{\circ} \mathrm{C}$ & 25 & 13 & 30 \\
\hline Electrical Conductivity (S/cm) & \\
\hline $900^{\circ} \mathrm{C}$ & 0.238 & 0.183 & 0.162 \\
\hline $950^{\circ} \mathrm{C}$ & 0.336 & 0.238 & 0.221 \\
\hline $1000^{\circ} \mathrm{C}$ & 0.443 & 0.302 & 0.288 \\
\hline $1050^{\circ} \mathrm{C}$ & 0.554 & 0.376 & 0.363 \\
\hline $1100^{\circ} \mathrm{C}$ & 0.668 & 0.462 & 0.445 \\
\hline $1150^{\circ} \mathrm{C}$ & 0.782 & 0.559 & 0.532 \\
\hline $1200^{\circ} \mathrm{C}$ & 0.895 & 0.667 & 0.625 \\
\hline $1250^{\circ} \mathrm{C}$ & 1.005 & 0.787 & 0.721 \\
\hline \multicolumn{4}{|c|}{} \\
\hline
\end{tabular}

Table 2.27. Results of K-3 Corrosion Testing for Five ORPLC Crucible Glasses.

\begin{tabular}{|c|c|c|c|}
\hline Glass ID & $\begin{array}{c}\text { Neck loss } \\
\text { (inches) }\end{array}$ & $\begin{array}{c}\text { Depth of altered } \\
\text { zone (inches) }\end{array}$ & $\begin{array}{c}\text { Half-down loss } \\
\text { (inches) }\end{array}$ \\
\hline ORPLC1 & 0.071 & 0.018 & 0.001 \\
\hline ORPLC2 & 0.083 & 0.032 & $\begin{array}{c}\text { Coupon expanded - } \\
\text { no measurable loss }\end{array}$ \\
\hline ORPLC3 & 0.030 & 0.028 & $\begin{array}{c}\text { Coupon expanded }- \\
\text { no measurable loss }\end{array}$ \\
\hline ORPLC4 & 0.073 & 0.029 & 0.003 \\
\hline ORPLC5 & 0.021 & 0.021 & $\begin{array}{c}\text { Coupon expanded }- \\
\text { no measurable loss }\end{array}$ \\
\hline
\end{tabular}


Table 2.28. Summary of Test Results for Selected ORPLC Glass Formulation ORPLC5 and Comparison to ILAW Requirements.

\begin{tabular}{|c|c|c|}
\hline Test & Requirement $[45,46]$ & $\begin{array}{l}\text { Test Result for } \\
\text { ORPLC5 }\end{array}$ \\
\hline Density of glass & $<3.7 \mathrm{~g} / \mathrm{cc}$ & Not measured \\
\hline Crystalline Phase & Phase identification & $\begin{array}{c}\text { Clear glass. }<<0.1 \text { vol\% of small } \mathrm{Cr} \\
\text { crystals }\end{array}$ \\
\hline Liquidus & $<950^{\circ} \mathrm{C}$ & $<950^{\circ} \mathrm{C}$ \\
\hline Centerline Canister Cooling & Phase identification & Not measured \\
\hline PCT B $\left(\mathrm{g} / \mathrm{m}^{2}\right)$ & $<2.0 \mathrm{~g} / \mathrm{m}^{2}$ & $0.85 \mathrm{~g} / \mathrm{m}^{2}$ \\
\hline PCT Na $\left(g / m^{2}\right)$ & $<2.0 \mathrm{~g} / \mathrm{m}^{2}$ & $0.74 \mathrm{~g} / \mathrm{m}^{2}$ \\
\hline PCT Si $\left(\mathrm{g} / \mathrm{m}^{2}\right)$ & $<2.0 \mathrm{~g} / \mathrm{m}^{2}$ & $0.18 \mathrm{~g} / \mathrm{m}^{2}$ \\
\hline VHT at $200^{\circ} \mathrm{C}\left(\mathrm{g} / \mathrm{m}^{2} /\right.$ day $)$ & $<50 \mathrm{~g} / \mathrm{m}^{2} /$ day & $\begin{array}{c}25 \text { and } 40 \mathrm{~g} / \mathrm{m}^{2} / \mathrm{day} \\
\text { (measurements on ORPLC and } \\
\text { ORPLCS4 samples) }\end{array}$ \\
\hline Viscosity (poise) at $1100^{\circ} \mathrm{C}$ & 10 to $150 \mathrm{P}$ & $128 \mathrm{P}$ \\
\hline Conductivity $(\mathrm{S} / \mathrm{cm})$ at $1100^{\circ} \mathrm{C}$ & 0.2 to $0.7 \mathrm{~S} / \mathrm{cm}$ & $0.445 \mathrm{~S} / \mathrm{cm}$ \\
\hline $\mathrm{T}_{\mathrm{G}}\left({ }^{\circ} \mathrm{C}\right)$ & Report for modeling & Not measured \\
\hline
\end{tabular}


Table 2.29. Oxide Composition of AN-104 Simulant and ORPLC5 Glass Composition Used in Melter Tests (wt\%).

\begin{tabular}{|c|c|c|c|}
\hline Component & AN-104 waste contribution & $\begin{array}{c}\text { Glass former } \\
\text { additives }\end{array}$ & $\begin{array}{c}\text { ORPLC5 } \\
\text { (for AN-104) }\end{array}$ \\
\hline Loading & $31.0 \%$ & $69.0 \%$ & - \\
\hline $\mathrm{Al}_{2} \mathrm{O}_{3}$ & 5.147 & 4.87 & 10.02 \\
\hline $\mathrm{B}_{2} \mathrm{O}_{3}$ & - & 8.50 & 8.50 \\
\hline $\mathrm{CaO}$ & - & 1.91 & 1.91 \\
\hline $\mathrm{Cr}_{2} \mathrm{O}_{3}$ & 0.034 & 0.50 & 0.53 \\
\hline $\mathrm{Cs}_{2} \mathrm{O}$ & 0.141 & - & 0.14 \\
\hline $\mathrm{Fe}_{2} \mathrm{O}_{3}$ & - & 0.97 & 0.97 \\
\hline $\mathrm{K}_{2} \mathrm{O}$ & 0.543 & - & 0.54 \\
\hline $\mathrm{MgO}$ & - & 0.93 & 0.93 \\
\hline $\mathrm{Na}_{2} \mathrm{O}^{(\mathrm{a})}$ & $22.110+0.542^{(1)}+0.918^{(2)}$ & - & 23.57 \\
\hline $\mathrm{SiO}_{2}$ & 0.053 & 39.96 & 40.01 \\
\hline $\mathrm{SnO}_{2}$ & - & 1.00 & 1.00 \\
\hline $\mathrm{V}_{2} \mathrm{O}_{5}$ & - & 2.00 & 2.00 \\
\hline $\mathrm{ZnO}$ & - & 2.36 & 2.36 \\
\hline $\mathrm{ZrO}_{2}$ & - & 6.02 & 6.02 \\
\hline $\mathrm{Cl}$ & 0.618 & - & 0.62 \\
\hline $\mathrm{F}$ & 0.008 & - & 0.01 \\
\hline $\mathrm{P}_{2} \mathrm{O}_{5}$ & 0.184 & - & 0.18 \\
\hline $\mathrm{SO}_{3}{ }^{(b)}$ & $0.700^{(1)}$ & - & 0.70 \\
\hline SUM & 31.0 & 69.0 & 100.0 \\
\hline
\end{tabular}

(a) Simulant was ordered at a concentration of $22.11 \mathrm{wt} \% \mathrm{Na}_{2} \mathrm{O}$ and modified before each melter test with (1) $\mathrm{Na}_{2} \mathrm{SO}_{4}$ and (2) $\mathrm{NaOH}$ additions to obtain $23.57 \mathrm{wt} \% \mathrm{Na}_{2} \mathrm{O}$ in the glass.

(b) Concentration of $\mathrm{SO}_{3}$ was increased in steps during the melter tests from $0.7 \mathrm{wt} \% \mathrm{SO}_{3}$ in the glass up to $0.9 \mathrm{wt} \%$.

- Empty data field 
Table 2.30a. Glass Former Additives for 1 Liter of AN-104 Simulant (8 M Na) and Corresponding Melter Feed Properties.

\begin{tabular}{|c|c|}
\hline Additives Source & Feed ORPLC5 \\
\hline Additives in Glass (wt\%) & 69.01 \\
\hline Kyanite $\left(\mathrm{Al}_{2} \mathrm{SiO}_{5}\right) 325$ Mesh (Kyanite Mining) (g) & 94.96 \\
\hline $\mathrm{H}_{3} \mathrm{BO}_{3}$ (US Borax - Technical Granular) (g) & 161.44 \\
\hline Wollanstonite NYAD 325 Mesh (NYCO Minerals) (g) & 42.59 \\
\hline $\mathrm{Cr}_{2} \mathrm{O}_{3}$ oxide & $5.32^{(1)}$ \\
\hline $\mathrm{Fe}_{2} \mathrm{O}_{3}$ (Prince Manufacturing) (g) & 8.16 \\
\hline Olivine $\left(\mathrm{Mg}_{2} \mathrm{SiO}_{4}\right) 325 \mathrm{Mesh}$ (\#180 Unimin) (g) & 19.85 \\
\hline $\mathrm{SiO}_{2}$ (Sil-co-Sil 75 US Silica) (g) & 320.66 \\
\hline SnO2 - Stannous Oxide - Mason color & 10.66 \\
\hline $\mathrm{V}_{2} \mathrm{O}_{5}$ - Pulva Ground - Stratcor & 21.04 \\
\hline ZnO (KADOX - 920 Zinc Corp. of America) (g) & 25.00 \\
\hline Zircon $\mathrm{ZrSiO}_{4}$ (Flour) Mesh 325 (AM. Mineral) (g) & 95.42 \\
\hline Supplemental $\mathrm{Na}_{2} \mathrm{SO}_{4}$ & Variable - Table 2.30b \\
\hline Addition of Sucrose as Reductant (g) & 6.21 \\
\hline Simulant Weight for 1 liter (g) & 1389.59 \\
\hline Sum of Additives (g) & 890 \\
\hline Sum of Complete Batch (g) & 2280 \\
\hline Target Final Volume (l) & 1.34 \\
\hline Estimated Density $(\mathrm{g} / \mathrm{ml})$ & 1.70 \\
\hline Target Glass Produced (g) & 1052 \\
\hline Target Weight \% Additives in Slurry & 39 \\
\hline Target Glass Yield (g/kg of Feed) & 461 \\
\hline Target Glass Yield (g/l of Feed) & 784 \\
\hline Target Total Solids (g/l of Feed) & 1007 \\
\hline Target Additives (g/l of Feed) & 664 \\
\hline
\end{tabular}

${ }^{(1)}$ Note that a $\mathrm{Cr}_{2} \mathrm{O}_{3}$ addition was cut down by $50 \%$ to account for K3-brick contribution.

Table 2.30b. $\mathrm{NaOH}$ and $\mathrm{Na}_{2} \mathrm{SO}_{4}$ Additions Required to Obtain $23.57 \mathrm{wt} \% \mathrm{Na}_{2} \mathrm{O}$ and Various $\mathrm{SO}_{3}$ Concentrations Ranging from 0.0 to 0.9 wt \% in the ORPLC5 Glass.

\begin{tabular}{|c|c|c|}
\hline $\begin{array}{c}\text { Final } \\
\mathrm{SO}_{3} \mathrm{wt} \%\end{array}$ & $\begin{array}{c}\text { NaOH needed } \\
\text { per kg of feed } \\
\text { (grams) }\end{array}$ & $\begin{array}{c}\mathrm{Na}_{2} \mathrm{SO}_{4} \text { needed } \\
\text { per kg of feed } \\
\text { (grams) }\end{array}$ \\
\hline 0.0 & 17.61 & - \\
\hline 0.7 & 11.07 & 5.88 \\
\hline 0.8 & 10.14 & 6.72 \\
\hline 0.9 & 9.21 & 7.56 \\
\hline
\end{tabular}


Table 2.31. LAW Sub-Envelope C2 (AN-102) Simulant Recipe at 8 Molar Sodium.

\begin{tabular}{|c|c|c|c|c|c|c|c|c|c|}
\hline \multirow{3}{*}{$\begin{array}{c}\begin{array}{c}\text { Envelope } \\
\text { Constituents }\end{array} \\
- \\
\mathrm{Al} \\
\end{array}$} & \multicolumn{2}{|c|}{$\begin{array}{c}\text { Simulant AN-102 } \\
\text { Including Pretreatment }\end{array}$} & \multirow{2}{*}{$\begin{array}{c}\text { Glass } \\
\text { Oxides }\end{array}$} & \multirow{2}{*}{$\begin{array}{c}\text { AN-102 } \\
\text { Simulant as } \\
\text { Oxides (wt\%) } \\
-\end{array}$} & Source in Simulant & \multirow{2}{*}{$\begin{array}{l}\text { Order for } \\
\text { Addition }\end{array}$} & \multirow[t]{2}{*}{$\begin{array}{l}\text { Formula } \\
\text { Weight }\end{array}$} & \multirow{2}{*}{$\begin{array}{l}\text { Assay* } \\
\text { low }\end{array}$} & \multirow[t]{2}{*}{$\begin{array}{c}\text { Target } \\
\text { Weight (g) }\end{array}$} \\
\hline & $\mathrm{mg} / \mathrm{L}$ & Molarity & & & In $430 \mathrm{ml}$ water add following compounds in the order listed below & & & & \\
\hline & 9922 & 0.368 & $\mathrm{Al}_{2} \mathrm{O}_{3}$ & 6.412 & $\mathrm{Al}\left(\mathrm{NO}_{3}\right)_{3} \cdot 9 \mathrm{H}_{2} \mathrm{O}, 60 \%$ sol. & 1 & 375.14 & 0.61 & 227.31 \\
\hline $\mathrm{B}$ & 30 & 0.003 & $\mathrm{~B}_{2} \mathrm{O}_{3}$ & 0.033 & Н3ВОЗ & 5 & 61.83 & 0.99 & 0.17 \\
\hline $\mathrm{Ca}$ & 396 & 0.010 & $\mathrm{CaO}$ & 0.190 & $\mathrm{Ca}\left(\mathrm{NO}_{3}\right)_{2} * 4 \mathrm{H}_{2} \mathrm{O}$ & 2 & 236.16 & 0.99 & 2.36 \\
\hline $\mathrm{Cr}$ & 174 & 0.003 & $\mathrm{Cr}_{2} \mathrm{O}_{3}$ & 0.087 & $\mathrm{Na}_{2} \mathrm{CrO}_{4} * 4 \mathrm{H}_{2} \mathrm{O}$ & 8 & 234.04 & 0.99 & 0.79 \\
\hline Cs spike & 1402 & 0.011 & $\mathrm{Cs}_{2} \mathrm{O}$ & 0.508 & $\mathrm{CsNO}_{3}$ & 3 & 194.91 & 1.00 & 2.06 \\
\hline $\mathrm{K}$ & 1604 & 0.041 & $\mathrm{~K}_{2} \mathrm{O}$ & 0.661 & $\mathrm{KOH}$ & 7 & 56.10 & 0.91 & 2.53 \\
\hline $\mathrm{Na}$ & 183920 & 8.000 & $\mathrm{Na}_{2} \mathrm{O}$ & 84.786 & $\mathrm{NaOH}, 50 \%$ sol. $\mathrm{D}=1.53$ & 6 & 40.00 & 0.50 & 161.17 \\
\hline $\mathrm{Ni}$ & 337 & 0.006 & $\mathrm{NiO}$ & 0.147 & $\mathrm{Ni}\left(\mathrm{NO}_{3}\right)_{2} * 6 \mathrm{H}_{2} \mathrm{O}$ & 4 & 290.81 & 1.00 & 1.67 \\
\hline $\mathrm{Pb}$ & 150 & 0.001 & $\mathrm{PbO}$ & 0.055 & $\mathrm{PbO}$ & 9 & 223.20 & 1.00 & 0.16 \\
\hline $\mathrm{Si}$ & 73 & 0.003 & $\mathrm{SiO}_{2}$ & 0.053 & $\mathrm{SiO}_{2}$ & 10 & 60.09 & 0.99 & 0.16 \\
\hline $\mathrm{Cl}$ & 3904 & 0.110 & $\mathrm{Cl}$ & 1.335 & $\mathrm{NaCl}$ & 11 & 58.45 & 0.99 & 6.50 \\
\hline $\mathrm{F}$ & 2025 & 0.107 & $\mathrm{~F}$ & 0.692 & $\mathrm{NaF}$ & 12 & 42.00 & 0.99 & 4.52 \\
\hline $\mathrm{PO}_{4}$ & 4508 & 0.047 & $\mathrm{P}_{2} \mathrm{O}_{5}$ & 1.152 & $\mathrm{Na}_{3} \mathrm{PO}_{4} .12 \mathrm{H}_{2} \mathrm{O}$ & 13 & 380.12 & 0.99 & 18.23 \\
\hline $\mathrm{SO}_{4}($ Nominal $)$ & 13648 & 0.142 & $\mathrm{SO}_{3}$ & 3.890 & $\mathrm{Na}_{2} \mathrm{SO}_{4}$ (varied content per run) & 14 & 142.06 & 0.99 & See Table 2.40b \\
\hline $\mathrm{NO}_{2}$ & 169129 & 1.503 & $\mathrm{NO}_{2}$ & - & $\mathrm{NaNO}_{2}$ & 20 & 69.00 & 1.00 & 104.21 \\
\hline $\mathrm{NO}_{3}$ & 178997 & 2.887 & $\mathrm{NO}_{3}$ & - & $\mathrm{NaNO}_{3}$ & 21 & 84.99 & 0.99 & 148.93 \\
\hline $\mathrm{CO}_{3}$ & 44356 & 0.739 & $\mathrm{CO}_{3}$ & - & $\mathrm{Na}_{2} \mathrm{CO}_{3}$ & 22 & 105.99 & 1.00 & 78.34 \\
\hline $\mathrm{NH}_{3}$ & 123 & 0.007 & $\mathrm{NH}_{3}$ & - & $\mathrm{NH}_{4} \mathrm{NO}_{3}$ & 19 & 80.04 & 1.00 & 0.58 \\
\hline Org.Carbon & 23569 & 1.964 & - & - & - & - & - & - & - \\
\hline Formate & 26113 & 0.580 & - & - & Sodium Formate (C1) & 15 & 68.01 & 0.99 & 38.85 \\
\hline Oxalate & 1501 & 0.017 & - & - & Sodium Oxalate (C2) & 16 & 134.00 & 0.99 & 2.31 \\
\hline Glycolate & 34273 & 0.451 & - & - & Glycolic Acid (C2) & 17 & 76.05 & 0.71 & 48.34 \\
\hline Citric Acid & 14362 & 0.075 & - & - & Citric Acid (C6) & 18 & 192.12 & 0.99 & 14.51 \\
\hline- & - & - & - & - & \multicolumn{4}{|c|}{ Target Glass Weight } & 1180.57 \\
\hline - & - & - & SUM & 100.000 & \multicolumn{4}{|c|}{ Total Simulant Weight } & 1315.10 \\
\hline
\end{tabular}

- Empty data field.

* Assay refers to the purity of the raw material as specified by the vendor. 
Table 2.32. Target and Analyzed Compositions (wt \%) of Three ORPLD Crucible Glasses.

\begin{tabular}{|c|c|c|c|c|c|c|}
\hline GLASS & \multicolumn{2}{|c|}{ ORPLD1 } & \multicolumn{2}{|c|}{ ORPLD2 } & \multicolumn{2}{|c|}{ ORPLD3 } \\
\hline Oxides & Target & Analyzed & Target & Analyzed* & Target & Analyzed* \\
\hline $\mathrm{Al}_{2} \mathrm{O}_{3}$ & 10.16 & 10.36 & 9.11 & 8.94 & 8.11 & 8.07 \\
\hline $\mathrm{B}_{2} \mathrm{O}_{3}$ & 12.05 & NA & 7.61 & NA & 8.61 & NA \\
\hline $\mathrm{CaO}$ & 8.02 & 8.12 & 8.02 & 8.18 & 10.02 & 10.05 \\
\hline $\mathrm{Cr}_{2} \mathrm{O}_{3}$ & 0.50 & 0.65 & 0.50 & 0.63 & 0.50 & 0.61 \\
\hline $\mathrm{Cs}_{2} \mathrm{O}$ (spike) & 0.13 & 0.14 & 0.13 & 0.12 & 0.13 & 0.12 \\
\hline $\mathrm{Fe}_{2} \mathrm{O}_{3}$ & 1.00 & 1.05 & 0.75 & 0.77 & 0.75 & 0.76 \\
\hline $\mathrm{K}_{2} \mathrm{O}$ & 0.16 & 0.22 & 0.16 & 0.18 & 0.16 & 0.18 \\
\hline $\mathrm{Li}_{2} \mathrm{O}$ & 0.00 & NA & 0.75 & NA & 0.75 & NA \\
\hline $\mathrm{MgO}$ & 1.00 & 0.97 & 1.00 & 0.95 & 1.00 & 0.93 \\
\hline $\mathrm{Na}_{2} \mathrm{O}$ & 21.00 & 20.39 & 21.00 & 20.71 & 21.00 & 20.69 \\
\hline $\mathrm{NiO}$ & 0.04 & 0.02 & 0.04 & 0.04 & 0.04 & 0.00 \\
\hline $\mathrm{PbO}$ & 0.01 & 0.02 & 0.01 & 0.02 & 0.01 & 0.02 \\
\hline $\mathrm{SiO}_{2}$ & 37.17 & 37.20 & 39.40 & 39.82 & 39.40 & 40.14 \\
\hline $\mathrm{SnO}_{2}$ & 0.00 & 0.01 & 1.00 & 1.06 & 0.00 & 0.01 \\
\hline $\mathrm{TiO}_{2}$ & 0.00 & 0.03 & 0.00 & 0.02 & 0.00 & 0.01 \\
\hline $\mathrm{V}_{2} \mathrm{O}_{5}$ & 1.00 & 1.10 & 1.00 & 1.10 & 1.00 & 1.06 \\
\hline $\mathrm{ZnO}$ & 3.00 & 3.06 & 2.51 & 2.57 & 2.51 & 2.45 \\
\hline $\mathrm{ZrO}_{2}$ & 3.00 & 2.81 & 5.26 & 4.92 & 4.26 & 3.97 \\
\hline $\mathrm{Cl}$ & 0.33 & 0.30 & 0.33 & 0.28 & 0.33 & 0.24 \\
\hline $\mathrm{F}$ & 0.17 & NA & 0.17 & NA & 0.17 & NA \\
\hline $\mathrm{P}_{2} \mathrm{O}_{5}$ & 0.29 & 0.32 & 0.29 & 0.32 & 0.29 & 0.33 \\
\hline $\mathrm{SO}_{3}$ & 0.96 & 1.06 & 0.96 & 0.77 & 0.96 & 0.84 \\
\hline SUM & 100.0 & 99.9 & 100.0 & 99.8 & 100.0 & 99.8 \\
\hline
\end{tabular}

* Analyzed by X-ray fluorescence NA - Not analyzed 


\section{Table 2.33. Descriptions of Three As-Melted and Heat Treated ORPLD Crucible Glasses.}

\begin{tabular}{|l|c|c|}
\hline Glass ID & As-melted glass & $\begin{array}{c}\text { Glass remelted at } \mathbf{1 2 0 0}{ }^{\circ} \mathbf{C} \text { for } \mathbf{1} \text { hour, heat } \\
\text { treated for } \mathbf{2 0} \text { hours at } \mathbf{9 5 0} \mathbf{C}^{\circ} \text {, and quenched. }\end{array}$ \\
\hline ORPLD1 & $\begin{array}{c}\text { Mostly clear glass. } \sim 0.1 \text { to } 0.2 \text { vol\% of } \\
\text { small Cr+Zn crystals }\end{array}$ & $\begin{array}{c}\text { Mostly clear glass. } \sim 0.1 \text { to } 0.2 \text { vol\% of small } \\
\text { Cr+Zn crystals }\end{array}$ \\
\hline ORPLD2 & Clear glass & Clear glass \\
\hline ORPLD3 & Clear glass & Clear glass \\
\hline
\end{tabular}

Table 2.34. Measured Sulfate Solubility Limits in Three ORPLD Crucible Glasses.

\begin{tabular}{|c|c|c|c|}
\hline \multirow{2}{*}{ Sample ID } & \multicolumn{3}{|c|}{ SO3 Content (wt\%) (Target Minimum $=0.6$ to $1.2 \mathrm{wt} \%)$} \\
\cline { 2 - 3 } & \multicolumn{2}{|c|}{ Batch Saturation } & \multirow{2}{*}{ Bubbling } \\
\cline { 2 - 3 } & As-Melted & After Acid Wash & \\
\hline ORPLD1S4 & 0.79 & 0.70 & - \\
\hline ORPLD2S4 & 0.90 & 0.82 & - \\
\hline ORPLD3S4 & 0.92 & 0.89 & - \\
\hline
\end{tabular}

\footnotetext{
Empty data field
} 
Table 2.35. Results of 7-day PCT (at $90^{\circ} \mathrm{C}$ ) and VHT (at $200^{\circ} \mathrm{C}$ for 24 Days) for Three ORPLD Crucible Glasses.

\begin{tabular}{|c|c|c|c|}
\hline Glass ID & ORPLD1 & ORPLD2 & ORPLD3 \\
\hline \multicolumn{4}{|c|}{ 7-Day PCT, Stainless Steel Vessel; S/V=2000m ${ }^{-1} \quad$ (ppm) } \\
\hline B & 49.32 & 26.95 & 22.44 \\
\hline $\mathrm{Na}$ & 223.60 & 234.00 & 203.90 \\
\hline $\mathrm{Si}$ & 53.61 & 70.99 & 66.27 \\
\hline \multicolumn{4}{|c|}{ Normalized Concentrations (g/L) } \\
\hline $\mathrm{B}$ & 1.32 & 1.14 & 0.84 \\
\hline $\mathrm{Na}$ & 1.44 & 1.50 & 1.31 \\
\hline $\mathrm{Si}$ & 0.31 & 0.39 & 0.36 \\
\hline $\mathrm{pH}$ & 11.45 & 11.71 & 11.72 \\
\hline \multicolumn{4}{|c|}{ 7-Day PCT Normalized Mass Loss $\left(\mathrm{g} / \mathrm{m}^{2}\right)$} \\
\hline B & 0.66 & 0.57 & 0.42 \\
\hline $\mathrm{Na}$ & 0.72 & 0.75 & 0.65 \\
\hline $\mathrm{Si}$ & 0.15 & 0.19 & 0.18 \\
\hline \multicolumn{4}{|c|}{ 7-Day PCT Normalized Loss Rate $\left(\mathrm{g} / \mathrm{m}^{2} / \mathrm{d}\right)$} \\
\hline $\mathrm{B}$ & 0.09 & 0.08 & 0.06 \\
\hline $\mathrm{Na}$ & 0.10 & 0.11 & 0.09 \\
\hline $\mathrm{Si}$ & 0.02 & 0.03 & 0.03 \\
\hline \multicolumn{4}{|c|}{$\begin{array}{l}\left.\text { VHT Alteration (24 days at } 200^{\circ} \mathrm{C}\right) \text { - Measurements on ORPLD and } \\
\text { ORPLDS4 Samples }\end{array}$} \\
\hline Alteration Depth $(\mu \mathrm{m})$ & $99 \pm 30$ & $99 \pm 126$ & $99 \pm 15$ \\
\hline Alteration Rate $\left(\mathrm{g} / \mathrm{m}^{2} /\right.$ day)* & $11 \pm 3$ & $11 \pm 14$ & $11 \pm 2$ \\
\hline Alteration Depth $(\mu \mathrm{m})$ & 141 & 34 & 209 \\
\hline Alteration Rate $\left(\mathrm{g} / \mathrm{m}^{2} / \text { day }\right)^{*}$ & 16 & 4 & 23 \\
\hline
\end{tabular}

* Alteration rates calculated using estimated density of $2.65 \mathrm{~g} / \mathrm{cc}$ 
Table 2.36. Viscosity and Electrical Conductivity of ORPLD1 Crucible Glass.

\begin{tabular}{|c|c|c|}
\hline Temperature $\left({ }^{\circ} \mathbf{C}\right)$ & Viscosity (poise) & $\begin{array}{c}\text { Electrical } \\
\text { Conductivity (S/cm) }\end{array}$ \\
\hline $900^{\circ} \mathrm{C}$ & 744 & 0.107 \\
\hline $950^{\circ} \mathrm{C}$ & 325 & 0.146 \\
\hline $1000^{\circ} \mathrm{C}$ & 162 & 0.189 \\
\hline $1050^{\circ} \mathrm{C}$ & 89 & 0.238 \\
\hline $1100^{\circ} \mathrm{C}$ & 53 & 0.291 \\
\hline $1150^{\circ} \mathrm{C}$ & 33 & 0.347 \\
\hline $1200^{\circ} \mathrm{C}$ & 22 & 0.406 \\
\hline $1250^{\circ} \mathrm{C}$ & 16 & 0.467 \\
\hline
\end{tabular}

Table 2.37. Results of K-3 Corrosion Testing for Three ORPLD Crucible Glasses.

\begin{tabular}{|c|c|c|c|}
\hline Glass ID & $\begin{array}{c}\text { Neck loss } \\
\text { (inches) }\end{array}$ & $\begin{array}{c}\text { Depth of altered } \\
\text { zone (inches) }\end{array}$ & $\begin{array}{c}\text { Half-down loss } \\
\text { (inches) }\end{array}$ \\
\hline ORPLD1 & 0.030 & 0.028 & $\begin{array}{c}\text { Coupon expanded - } \\
\text { no measurable loss }\end{array}$ \\
\hline ORPLD2 & 0.050 & 0.021 & 0.002 \\
\hline ORPLD3 & 0.091 & 0.026 & 0.003 \\
\hline
\end{tabular}


Table 2.38. Summary of Test Results for Selected ORPLD Glass Formulation ORPLD1 and Comparison to ILAW Requirements.

\begin{tabular}{|c|c|c|}
\hline Test & Requirement $[45,46]$ & $\begin{array}{l}\text { Test Result for } \\
\text { ORPLD1 }\end{array}$ \\
\hline Density of glass & $<3.7 \mathrm{~g} / \mathrm{cc}$ & Not measured \\
\hline Crystalline Phase & Phase identification & $\begin{array}{c}\text { Clear homogeneous glass } \\
\text { with not more than } 0.2 \text { vol\% crystals } \\
\text { after heat treatment at } 950^{\circ} \mathrm{C} \text { for } 20 \\
\text { hours }\end{array}$ \\
\hline Liquidus & $<950^{\circ} \mathrm{C}$ & $<950^{\circ} \mathrm{C}$ \\
\hline Centerline Canister Cooling & Phase identification & Not measured \\
\hline PCT B $\left(\mathrm{g} / \mathrm{m}^{2}\right)$ & $<2.0 \mathrm{~g} / \mathrm{m}^{2}$ & $0.66 \mathrm{~g} / \mathrm{m}^{2}$ \\
\hline PCT Na $\left(\mathrm{g} / \mathrm{m}^{2}\right)$ & $<2.0 \mathrm{~g} / \mathrm{m}^{2}$ & $0.72 \mathrm{~g} / \mathrm{m}^{2}$ \\
\hline PCT Si $\left(g / m^{2}\right)$ & $<2.0 \mathrm{~g} / \mathrm{m}^{2}$ & $0.15 \mathrm{~g} / \mathrm{m}^{2}$ \\
\hline VHT at $200^{\circ} \mathrm{C}\left(\mathrm{g} / \mathrm{m}^{2} /\right.$ day $)$ & $<50 \mathrm{~g} / \mathrm{m}^{2} /$ day & $\begin{array}{l}11 \text { and } 16 \mathrm{~g} / \mathrm{m}^{2} / \mathrm{day} \\
\text { (measurements on ORPLD and } \\
\text { ORPLDS4 samples) }\end{array}$ \\
\hline Viscosity (poise) at $1100^{\circ} \mathrm{C}$ & 10 to $150 \mathrm{P}$ & $53 \mathrm{P}$ \\
\hline Conductivity $(\mathrm{S} / \mathrm{cm})$ at $1100^{\circ} \mathrm{C}$ & 0.2 to $0.7 \mathrm{~S} / \mathrm{cm}$ & $0.291 \mathrm{~S} / \mathrm{cm}$ \\
\hline $\mathrm{T}_{\mathrm{G}}\left({ }^{\circ} \mathrm{C}\right)$ & Report for modeling & Not measured \\
\hline
\end{tabular}


Table 2.39. Oxide Composition of AN-102 Simulant and ORPLD1 Glass Composition Used in Melter Tests (wt\%).

\begin{tabular}{|c|c|c|c|}
\hline Component & AN-102 waste contribution & $\begin{array}{c}\text { Glass former } \\
\text { additives }\end{array}$ & $\begin{array}{c}\text { ORPLD1 } \\
\text { (for AN-102) }\end{array}$ \\
\hline Loading & $24.9 \%$ & $75.1 \%$ & - \\
\hline $\mathrm{Al}_{2} \mathrm{O}_{3}$ & 1.588 & 8.56 & 10.15 \\
\hline $\mathrm{B}_{2} \mathrm{O}_{3}$ & 0.008 & 12.01 & 12.02 \\
\hline $\mathrm{CaO}$ & 0.047 & 7.96 & 8.01 \\
\hline $\mathrm{Cr}_{2} \mathrm{O}_{3}$ & 0.022 & 0.48 & 0.50 \\
\hline $\mathrm{Cs}_{2} \mathrm{O}$ & 0.126 & - & 0.13 \\
\hline $\mathrm{Fe}_{2} \mathrm{O}_{3}$ & - & 1.00 & 1.00 \\
\hline $\mathrm{K}_{2} \mathrm{O}$ & 0.164 & - & 0.16 \\
\hline $\mathrm{MgO}$ & - & 1.00 & 1.00 \\
\hline $\mathrm{Na}_{2} \mathrm{O}^{(\mathrm{a})}$ & $19.374+0.852^{(1)}+0.774^{(2)}$ & - & 21.00 \\
\hline $\mathrm{NiO}$ & 0.036 & - & 0.04 \\
\hline $\mathrm{PbO}$ & 0.014 & - & 0.01 \\
\hline $\mathrm{SiO}_{2}$ & 0.013 & 37.10 & 37.11 \\
\hline $\mathrm{V}_{2} \mathrm{O}_{5}$ & - & 1.00 & 1.00 \\
\hline $\mathrm{ZnO}$ & - & 3.00 & 3.00 \\
\hline $\mathrm{ZrO}_{2}$ & - & 3.00 & 3.00 \\
\hline $\mathrm{Cl}$ & 0.331 & - & 0.33 \\
\hline $\mathrm{F}$ & 0.172 & - & 0.17 \\
\hline $\mathrm{P}_{2} \mathrm{O}_{5}$ & 0.281 & - & 0.28 \\
\hline $\mathrm{SO}_{3}^{(b)}$ & $1.100^{(1)}$ & - & 1.10 \\
\hline SUM & 24.9 & 75.1 & 100.0 \\
\hline
\end{tabular}

(a) Simulant was ordered at a concentration of $19.37 \mathrm{wt} \% \mathrm{Na}_{2} \mathrm{O}$ and modified before each melter test with (1) $\mathrm{Na}_{2} \mathrm{SO}_{4}$ and (2) $\mathrm{NaOH}$ additions to obtain $21.0 \mathrm{wt} \% \mathrm{Na}_{2} \mathrm{O}$ in the glass.

(b) Concentration of $\mathrm{SO}_{3}$ was increased in steps during the melter tests from $0.7 \mathrm{wt} \% \mathrm{SO}_{3}$ in the glass up to $1.3 \mathrm{wt} \%$.

- Empty data field 
Table 2.40a. Glass Former Additives for 1 Liter of AN-102 Simulant (8 M Na) and Corresponding Melter Feed Properties.

\begin{tabular}{|c|c|}
\hline Additives Source & Feed ORPLD1 \\
\hline Additives in Glass (wt\%) & 75.10 \\
\hline Kyanite $\left(\mathrm{Al}_{2} \mathrm{SiO}_{5}\right) 325$ Mesh (Kyanite Mining) (g) & 177.01 \\
\hline $\mathrm{H}_{3} \mathrm{BO}_{3}$ (US Borax - Technical Granular) (g) & 252.66 \\
\hline Wollanstonite NYAD 325 Mesh (NYCO Minerals) (g) & 198.69 \\
\hline $\mathrm{Cr}_{2} \mathrm{O}_{3}$ oxide & $5.80^{(1)}$ \\
\hline $\mathrm{Fe}_{2} \mathrm{O}_{3}$ (Prince Manufacturing) (g) & 8.51 \\
\hline Olivine $\left(\mathrm{Mg}_{2} \mathrm{SiO}_{4}\right) 325 \mathrm{Mesh}(\# 180$ Unimin) (g) & 21.42 \\
\hline $\mathrm{SiO}_{2}$ (Sil-co-Sil 75 US Silica) (g) & 235.82 \\
\hline $\mathrm{V}_{2} \mathrm{O}_{5}-$ Pulva Ground - Stratcor & 11.82 \\
\hline ZnO (KADOX - 920 Zinc Corp. of America) (g) & 35.48 \\
\hline Zircon $\mathrm{ZrSiO}_{4}$ (Flour) Mesh 325 (AM. Mineral) (g) & 53.23 \\
\hline Supplemental $\mathrm{Na}_{2} \mathrm{SO}_{4}$ & Variable - Table 2.40b \\
\hline Addition of Sucrose as Reductant (g) & 37.86 \\
\hline Simulant Weight for 1 liter (g) & 1315.10 \\
\hline Sum of Additives (g) & 1038 \\
\hline Sum of Complete Batch (g) & 2353 \\
\hline Target Final Volume (l) & 1.38 \\
\hline Estimated Density (g/ml) & 1.70 \\
\hline Target Glass Produced (g) & 1181 \\
\hline Target Weight \% Additives in Slurry & 44 \\
\hline Target Glass Yield (g/kg of Feed) & 502 \\
\hline Target Glass Yield (g/l of Feed) & 853 \\
\hline Target Total Solids (g/l of Feed) & 1068 \\
\hline Target Additives (g/l of Feed) & 750 \\
\hline
\end{tabular}

${ }^{(1)}$ Note that a $\mathrm{Cr}_{2} \mathrm{O}_{3}$ addition was cut down by $50 \%$ to account for K3-brick contribution.

Table 2.40b. $\mathrm{NaOH}$ and $\mathrm{Na}_{2} \mathrm{SO}_{4}$ Additions Required to Obtain $21 \mathrm{wt} \% \mathrm{Na}_{2} \mathrm{O}$ and Various $\mathrm{SO}_{3}$ Concentrations Ranging from 0.0 to $1.3 \mathrm{wt} \%$ in the ORPLD1Glass.

\begin{tabular}{|c|c|c|}
\hline $\begin{array}{c}\text { Final } \\
\mathrm{SO}_{3} \mathrm{wt} \%\end{array}$ & $\begin{array}{c}\mathrm{NaOH} \text { needed } \\
\text { per kg of feed } \\
\text { (grams) }\end{array}$ & $\begin{array}{c}\mathrm{Na}_{2} \mathrm{SO}_{4} \text { needed } \\
\text { per kg of feed } \\
\text { (grams) }\end{array}$ \\
\hline 0.0 & 21.41 & - \\
\hline 0.7 & 13.77 & 6.20 \\
\hline 0.8 & 12.79 & 7.08 \\
\hline 0.9 & 11.81 & 7.96 \\
\hline 1.0 & 10.82 & 8.85 \\
\hline 1.1 & 9.84 & 9.73 \\
\hline 1.2 & 8.85 & 10.62 \\
\hline 1.3 & 7.87 & 11.50 \\
\hline
\end{tabular}


Table 2.41. LAW Sub-Envelope B1 (AZ-101) Waste Simulant Recipe at 7.0 Molar Sodium.

\begin{tabular}{|c|c|c|c|c|c|c|c|c|c|c|}
\hline $\begin{array}{c}\text { Envelope } \\
\text { Constituents }\end{array}$ & \multicolumn{2}{|c|}{$\begin{array}{c}\text { Simulant AZ-101 } \\
\text { Including Pretreatment }\end{array}$} & $\begin{array}{l}\text { Glass } \\
\text { Oxides }\end{array}$ & $\begin{array}{c}\text { LAW B1 } \\
\text { Simulant as } \\
\text { Oxides (wt\%) }\end{array}$ & $\begin{array}{c}\text { Waste } \\
\text { Contribution to } \\
\text { Glass }\end{array}$ & $\begin{array}{l}\text { Source in } \\
\text { Simulant }\end{array}$ & $\begin{array}{l}\text { Order for } \\
\text { Addition }\end{array}$ & $\begin{array}{l}\text { Formula } \\
\text { Weight }\end{array}$ & Assay* & $\begin{array}{c}\text { Target } \\
\text { Weight (g) }\end{array}$ \\
\hline- & $\mathrm{mg} / \mathrm{L}$ & $\mathrm{M}$ & Loading & & $19.57 \%$ & \multicolumn{5}{|c|}{ In $547 \mathrm{ml}$ water add following compounds in the order listed below } \\
\hline $\mathrm{Al}$ & 8331 & 0.309 & $\mathrm{Al}_{2} \mathrm{O}_{3}$ & 5.932 & 1.16 & $\mathrm{Al}\left(\mathrm{NO}_{3}\right)_{3} \cdot 9 \mathrm{H}_{2} \mathrm{O}, 60 \%$ sol. & 1 & 375.14 & 0.61 & 190.88 \\
\hline $\mathrm{Cr}$ & 944 & 0.018 & $\mathrm{Cr}_{2} \mathrm{O}_{3}$ & 0.520 & 0.102 & $\mathrm{Na}_{2} \mathrm{CrO}_{4} \cdot 4 \mathrm{H}_{2} \mathrm{O}$ & 6 & 234.04 & 0.99 & 4.31 \\
\hline Cs spike & 1917 & 0.014 & $\mathrm{Cs}_{2} \mathrm{O}$ & 0.766 & 0.150 & $\mathrm{CsNO}_{3}$ & 2 & 194.91 & 1.00 & 2.82 \\
\hline $\mathrm{K}$ & 6139 & 0.157 & $\mathrm{~K}_{2} \mathrm{O}$ & 2.786 & 0.545 & $\mathrm{KOH}$ & 5 & 56.10 & 0.91 & 9.70 \\
\hline $\mathrm{Na}$ & 160930 & 7.000 & $\mathrm{Na}_{2} \mathrm{O}$ & 81.739 & 16.000 & $\mathrm{NaOH}, 50 \%$ sol. $\mathrm{d}=1.53$ & 4 & 40.00 & 0.50 & 334.82 \\
\hline $\mathrm{Si}$ & 94 & 0.003 & $\mathrm{SiO}_{2}$ & 0.075 & 0.015 & $\mathrm{SiO}_{2}$ & 3 & 60.09 & 0.99 & 0.20 \\
\hline $\mathrm{Cl}$ & 334 & 0.009 & $\mathrm{Cl}$ & 0.126 & 0.025 & $\mathrm{NaCl}$ & 7 & 58.45 & 0.99 & 0.56 \\
\hline $\mathrm{F}$ & 2762 & 0.145 & $\mathrm{~F}$ & 1.041 & 0.204 & $\mathrm{NaF}$ & 8 & 42.00 & 0.99 & 6.17 \\
\hline $\mathrm{PO}_{4}$ & 2239 & 0.024 & $\mathrm{P}_{2} \mathrm{O}_{5}$ & 0.631 & 0.123 & $\mathrm{Na}_{3} \mathrm{PO}_{4} \cdot 12 \mathrm{H}_{2} \mathrm{O}$ & 9 & 380.12 & 0.99 & 9.05 \\
\hline $\mathrm{SO}_{4}$ (Nominal) & 20327 & 0.212 & $\mathrm{SO}_{3}$ & 6.384 & 1.250 & $\mathrm{Na}_{2} \mathrm{SO}_{4}$ (varied content per run) & 10 & 142.06 & 0.99 & (See Table 2.50b) \\
\hline $\mathrm{NO}_{2}$ & 84374 & 1.834 & $\mathrm{NO}_{2}$ & - & - & $\mathrm{NaNO}_{2}$ & 13 & 69.00 & 1.00 & 127.20 \\
\hline $\mathrm{NO}_{3}$ & 72354 & 1.167 & $\mathrm{NO}_{3}$ & - & - & $\mathrm{NaNO}_{3}$ & 14 & 84.99 & 0.99 & 19.42 \\
\hline Org.Carbon & 702 & 0.0258 & - & - & - & - & - & - & - & - \\
\hline formate & 689 & 0.015 & - & - & - & Sodium Formate (C1) & 11 & 68.01 & 0.99 & 1.05 \\
\hline Oxalate & 1898 & 0.022 & - & - & - & Sodium Oxalate (C2) & 12 & 134.00 & 0.99 & 2.92 \\
\hline- & - & - & - & - & - & \multicolumn{4}{|c|}{ Target Glass Weight } & 1355.81 \\
\hline- & - & - & SUM & 100 & 19.574 & \multicolumn{4}{|c|}{ Total Simulant Weight } & 1286.35 \\
\hline
\end{tabular}

- Empty data field.

* Assay refers to the purity of the raw material as specified by the vendor. 


\section{Table 2.42. Target and Analyzed Compositions (wt\%) of Twelve ORPLE Crucible Glasses.}

\begin{tabular}{|c|c|c|c|c|c|c|c|c|c|c|c|c|}
\hline \multirow{2}{*}{$\begin{array}{c}\text { GLASS } \\
\text { Oxides }\end{array}$} & \multicolumn{2}{|c|}{ ORPLE1 } & \multicolumn{2}{|c|}{ ORPLE2 } & \multicolumn{2}{|c|}{ ORPLE3 } & \multicolumn{2}{|c|}{ ORPLE4 } & \multicolumn{2}{|c|}{ ORPLE5 } & \multicolumn{2}{|c|}{ ORPLE6 } \\
\hline & Target & Analyzed $^{*}$ & Target & Analyzed $^{*}$ & Target & Analyzed* & Target & Analyzed* & Target & Analyzed $^{*}$ & Target & Analyzed \\
\hline $\mathrm{Al}_{2} \mathrm{O}_{3}$ & 7.60 & 8.06 & 10.01 & 10.23 & 10.01 & 10.19 & 7.64 & 7.78 & 7.60 & 7.85 & 7.60 & 7.86 \\
\hline $\mathrm{B}_{2} \mathrm{O}_{3}$ & 9.85 & 10.05 & 11.46 & 11.78 & 11.46 & 11.64 & 9.81 & 10.28 & 9.61 & 10.02 & 9.85 & 9.98 \\
\hline $\mathrm{CaO}$ & 10.46 & 10.06 & 8.04 & 8.10 & 10.46 & 10.69 & 10.43 & 10.19 & 10.24 & 10.40 & 9.97 & 10.08 \\
\hline $\mathrm{Cr}_{2} \mathrm{O}_{3}$ & 0.10 & 0.12 & 0.10 & 0.14 & 0.10 & 0.14 & 0.11 & 0.15 & 0.13 & 0.17 & 0.50 & 0.624 \\
\hline $\mathrm{Cs}_{2} \mathrm{O}$ (spike) & 0.15 & 0.17 & 0.15 & 0.19 & 0.15 & 0.16 & 0.15 & 0.23 & 0.15 & 0.18 & 0.15 & 0.173 \\
\hline $\mathrm{Fe}_{2} \mathrm{O}_{3}$ & 0.24 & 0.26 & 0.24 & 0.27 & 0.24 & 0.29 & 0.23 & 0.29 & 0.23 & 0.29 & 0.24 & 0.293 \\
\hline $\mathrm{K}_{2} \mathrm{O}$ & 0.55 & 0.55 & 0.55 & 0.58 & 0.55 & 0.57 & 0.61 & 0.62 & 0.68 & 0.73 & 0.55 & 0.592 \\
\hline $\mathrm{Li}_{2} \mathrm{O}$ & 3.00 & 3.18 & 3.00 & 3.20 & 3.00 & 3.25 & 2.10 & 2.36 & 1.10 & 1.33 & 3.00 & 3.17 \\
\hline $\mathrm{MgO}$ & 1.05 & 1.09 & 1.05 & 1.07 & 1.05 & 1.06 & 1.05 & 1.08 & 0.99 & 0.92 & 1.05 & 0.924 \\
\hline $\mathrm{Na}_{2} \mathrm{O}$ & 16.00 & 16.70 & 16.00 & 15.96 & 16.00 & 16.13 & 18.00 & 18.58 & 20.00 & 19.54 & 16.00 & 16.11 \\
\hline $\mathrm{SiO}_{2}$ & 41.41 & 41.37 & 39.80 & 39.75 & 37.39 & 36.87 & 40.34 & 39.29 & 39.95 & 40.12 & 41.41 & 41.24 \\
\hline $\mathrm{SnO}_{2}$ & 0.00 & 0.00 & 0.00 & 0.00 & 0.00 & 0.00 & 0.00 & 0.00 & 0.00 & 0.00 & 0.00 & 0.00 \\
\hline $\mathrm{TiO}_{2}$ & 0.00 & 0.03 & 0.00 & 0.03 & 0.00 & 0.03 & 0.00 & 0.03 & 0.00 & 0.03 & 0.00 & 0.035 \\
\hline $\mathrm{V}_{2} \mathrm{O}_{5}$ & 1.25 & 1.25 & 1.25 & 1.31 & 1.25 & 1.36 & 1.21 & 1.30 & 1.18 & 1.26 & 1.25 & 1.33 \\
\hline $\mathrm{ZnO}$ & 3.22 & 2.97 & 3.22 & 3.15 & 3.22 & 3.24 & 3.13 & 3.34 & 2.96 & 2.95 & 3.22 & 3.17 \\
\hline $\mathrm{ZrO}_{2}$ & 3.54 & 3.08 & 3.54 & 3.32 & 3.54 & 3.38 & 3.53 & 3.75 & 3.51 & 3.33 & 3.62 & 3.28 \\
\hline $\mathrm{Cl}$ & 0.02 & 0.03 & 0.02 & 0.02 & 0.02 & 0.02 & 0.03 & 0.02 & 0.03 & 0.02 & 0.02 & 0.019 \\
\hline $\mathrm{F}$ & 0.20 & NA & 0.20 & NA & 0.20 & NA & 0.23 & NA & 0.25 & NA & 0.20 & NA \\
\hline $\mathrm{P}_{2} \mathrm{O}_{5}$ & 0.12 & 0.18 & 0.12 & 0.18 & 0.12 & 0.18 & 0.14 & 0.20 & 0.15 & 0.22 & 0.12 & 0.167 \\
\hline $\mathrm{SO}_{3}$ & 1.25 & 1.13 & 1.25 & 1.09 & 1.25 & 1.11 & 1.25 & 1.08 & 1.25 & 1.15 & 1.25 & 1.13 \\
\hline SUM & 100.0 & 100.5 & 100.0 & 100.6 & 100.0 & 100.5 & 100.0 & 100.8 & 100.0 & 100.8 & 100.0 & 100.4 \\
\hline
\end{tabular}


Table 2.42. Target and Analyzed Compositions (wt\%) of Twelve ORPLE Crucible Glasses (continued).

\begin{tabular}{|c|c|c|c|c|c|c|c|c|c|c|c|c|}
\hline \multirow{2}{*}{$\begin{array}{c}\text { GLASS } \\
\text { Oxides }\end{array}$} & \multicolumn{2}{|c|}{ ORPLE7 } & \multicolumn{2}{|c|}{ ORPLE8 } & \multicolumn{2}{|c|}{ ORPLE9 } & \multicolumn{2}{|c|}{ ORPLE10 } & \multicolumn{2}{|c|}{ ORPLE11 } & \multicolumn{2}{|c|}{ ORPLE12 } \\
\hline & Target & Analyzed $^{*}$ & Target & Analyzed ${ }^{*}$ & Target & Analyzed* & Target & Analyzed ${ }^{*}$ & Target & Analyzed $^{*}$ & Target & Analyzed \\
\hline $\mathrm{Al}_{2} \mathrm{O}_{3}$ & 7.60 & 7.89 & 7.60 & 7.95 & 7.60 & 7.81 & 8.80 & 9.31 & 7.60 & 7.94 & 7.60 & 8.05 \\
\hline $\mathrm{B}_{2} \mathrm{O}_{3}$ & 9.85 & 9.65 & 9.45 & 9.47 & 9.05 & 9.00 & 10.46 & 10.26 & 9.85 & 9.75 & 9.85 & 9.80 \\
\hline $\mathrm{CaO}$ & 10.46 & 10.50 & 10.05 & 10.18 & 9.65 & 9.80 & 9.25 & 9.49 & 10.46 & 10.45 & 10.05 & 10.21 \\
\hline $\mathrm{Cr}_{2} \mathrm{O}_{3}$ & 0.50 & 0.63 & 0.10 & 0.14 & 0.50 & 0.62 & 0.10 & 0.14 & 0.10 & 0.16 & 0.50 & 0.63 \\
\hline $\mathrm{Cs}_{2} \mathrm{O}$ (spike) & 0.15 & 0.18 & 0.15 & 0.17 & 0.15 & 0.18 & 0.15 & 0.16 & 0.15 & 0.16 & 0.15 & 0.16 \\
\hline $\mathrm{Fe}_{2} \mathrm{O}_{3}$ & 0.24 & 0.28 & 1.05 & 1.07 & 1.05 & 1.07 & 0.24 & 0.30 & 0.24 & 0.29 & 0.24 & 0.29 \\
\hline $\mathrm{K}_{2} \mathrm{O}$ & 0.55 & 0.59 & 0.55 & 0.60 & 0.55 & 0.58 & 0.55 & 0.62 & 0.55 & 0.58 & 0.55 & 0.61 \\
\hline $\mathrm{Li}_{2} \mathrm{O}$ & 2.60 & 2.71 & 3.00 & 3.16 & 3.00 & 3.10 & 3.00 & 3.08 & 2.50 & 2.61 & 2.50 & 2.57 \\
\hline $\mathrm{MgO}$ & 1.05 & 0.94 & 1.05 & 0.89 & 1.05 & 0.97 & 1.05 & 0.88 & 1.05 & 0.95 & 1.05 & 0.86 \\
\hline $\mathrm{Na}_{2} \mathrm{O}$ & 16.00 & 16.20 & 16.00 & 16.23 & 16.00 & 16.14 & 16.00 & 15.28 & 16.00 & 16.52 & 16.00 & 15.74 \\
\hline $\mathrm{SiO}_{2}$ & 41.41 & 41.14 & 41.41 & 41.16 & 41.41 & 41.17 & 40.81 & 40.79 & 41.41 & 41.00 & 41.41 & 41.41 \\
\hline $\mathrm{SnO}_{2}$ & 0.00 & 0.00 & 0.00 & 0.00 & 0.00 & 0.00 & 0.00 & 0.01 & 0.00 & 0.00 & $0 . .00$ & 0.01 \\
\hline $\mathrm{TiO}_{2}$ & 0.00 & 0.03 & 0.00 & 0.03 & 0.00 & 0.03 & 0.00 & 0.04 & 0.00 & 0.03 & 0.00 & 0.03 \\
\hline $\mathrm{V}_{2} \mathrm{O}_{5}$ & 1.25 & 1.33 & 1.25 & 1.32 & 1.25 & 1.35 & 1.25 & 1.36 & 1.75 & 1.85 & 1.75 & 1.84 \\
\hline $\mathrm{ZnO}$ & 3.22 & 3.18 & 3.22 & 3.20 & 3.22 & 3.20 & 3.22 & 3.24 & 3.22 & 3.14 & 3.22 & 3.20 \\
\hline $\mathrm{ZrO}_{2}$ & 3.54 & 3.20 & 3.54 & 3.18 & 3.94 & 3.57 & 3.54 & 3.25 & 3.54 & 3.14 & 3.54 & 3.23 \\
\hline $\mathrm{Cl}$ & 0.02 & 0.02 & 0.02 & 0.02 & 0.02 & 0.02 & 0.02 & 0.03 & 0.02 & 0.02 & 0.02 & 0.03 \\
\hline $\mathrm{F}$ & 0.20 & NA & 0.20 & NA & 0.20 & NA & 0.20 & NA & 0.20 & NA & 0.20 & NA \\
\hline $\mathrm{P}_{2} \mathrm{O}_{5}$ & 0.12 & 0.18 & 0.12 & 0.19 & 0.12 & 0.18 & 0.12 & 0.18 & 0.12 & 0.19 & 0.12 & 0.19 \\
\hline $\mathrm{SO}_{3}$ & 1.25 & 1.13 & 1.25 & 1.13 & 1.25 & 1.13 & 1.25 & 1.33 & 1.25 & 1.11 & 1.25 & 1.05 \\
\hline SUM & 100.0 & 100.0 & 100.0 & 100.3 & 100.0 & 100.1 & 100.0 & 100.0 & 100.0 & 100.1 & 100.0 & 100.1 \\
\hline
\end{tabular}


Table 2.43. Descriptions of Twelve As-Melted and Heat Treated ORPLE Crucible Glasses.

\begin{tabular}{|c|c|c|}
\hline Glass ID & As-melted glass & $\begin{array}{l}\text { Glass remelted at } 1200^{\circ} \mathrm{C} \text { for } 1 \text { hour, heat treated for } 20 \text { hours } \\
\text { at } 850^{\circ} \mathrm{C} \text {, and quenched. }\end{array}$ \\
\hline ORPLE1 & Clear glass & $\begin{array}{c}\text { Clear glass. }<0.1 \text { vol\% sodalite (Na-Al silicate sulfate) at } \\
\text { platinum crucible interface. }\end{array}$ \\
\hline ORPLE2 & Clear glass & $\begin{array}{c}\text { Clear glass. }<0.1 \text { vol\% sodalite (Na-Al silicate sulfate) at } \\
\text { platinum crucible interface. }\end{array}$ \\
\hline ORPLE3 & Clear glass & $\begin{array}{c}\text { Clear glass. }<0.1 \text { vol\% sodalite (Na-Al silicate sulfate) at } \\
\text { platinum crucible interface. }\end{array}$ \\
\hline ORPLE4 & Clear glass & $\begin{array}{c}\text { Clear glass. }<0.1 \text { vol\% sodalite (Na-Al silicate sulfate) at } \\
\text { platinum crucible interface. }\end{array}$ \\
\hline ORPLE5 & Clear glass & $\begin{array}{c}\text { Clear glass. }<0.1 \text { vol\% sodalite (Na-Al silicate sulfate) at } \\
\text { platinum crucible interface. }\end{array}$ \\
\hline ORPLE6 & Clear glass & $\begin{array}{c}\text { Clear glass. }<0.1 \text { vol\% sodalite (Na-Al silicate sulfate) at } \\
\text { platinum crucible interface. }\end{array}$ \\
\hline ORPLE7 & Clear glass & $\begin{array}{c}\text { Clear glass. }<0.1 \text { vol\% sodalite (Na-Al silicate sulfate) at } \\
\text { platinum crucible interface. }\end{array}$ \\
\hline ORPLE8 & Clear glass & $\begin{array}{c}\text { Clear glass. } \sim 0.2 \text { vol\% sodalite (Na-Al silicate sulfate) at platinum } \\
\text { crucible interface. }\end{array}$ \\
\hline ORPLE9 & Clear glass & $\begin{array}{c}\text { Clear glass. } \sim 0.1 \text { vol\% sodalite (Na-Al silicate sulfate) at platinum } \\
\text { crucible interface. }\end{array}$ \\
\hline ORPLE10 & Clear glass & $\begin{array}{c}\text { Clear glass. } \sim 0.2 \text { vol\% sodalite (Na-Al silicate sulfate) at platinum } \\
\text { crucible interface. }\end{array}$ \\
\hline ORPLE11 & Clear glass & $\begin{array}{c}\text { Clear glass. }<0.1 \text { vol\% sodalite (Na-Al silicate sulfate) at } \\
\text { platinum crucible interface. }\end{array}$ \\
\hline ORPLE12 & Clear glass & $\begin{array}{c}\text { Clear glass. }<0.1 \text { vol\% sodalite (Na-Al silicate sulfate) at } \\
\text { platinum crucible interface. }\end{array}$ \\
\hline
\end{tabular}


Table 2.44. Measured Sulfate Solubility Limits in Twelve ORPLE Crucible Glasses.

\begin{tabular}{|c|c|c|c|}
\hline \multirow{2}{*}{ Sample ID } & \multicolumn{2}{|c|}{ SO $_{3}$ Content (wt\%) (Target Minimum $=0.8$ to 1.4 wt\%) } \\
\cline { 2 - 4 } & \multicolumn{2}{|c|}{ Batch Saturation } & \multirow{2}{*}{ Bubbling* } \\
\cline { 2 - 4 } & As-Melted & After Acid Wash & \multirow{2}{*}{1.66} \\
\hline ORPLE1S4 & 1.68 & 1.66 & 1.38 \\
\hline ORPLE2S4 & 1.54 & 1.43 & 1.51 \\
\hline ORPLE3S4 & 1.61 & 1.24 & 1.44 \\
\hline ORPLE4S4 & 1.70 & 1.30 & - \\
\hline ORPLE5S4 & 1.29 & 1.18 & 1.50 \\
\hline ORPLE6S4 & 1.69 & 1.24 & 1.52 \\
\hline ORPLE7S4 & 1.51 & 1.23 & - \\
\hline ORPLE8S4 & 1.67 & 1.26 & 1.44 \\
\hline ORPLE9S4 & 1.70 & 1.19 & - \\
\hline ORPLE10S4 & 1.87 & 1.24 & - \\
\hline ORPLE11S4 & 1.49 & 1.29 & 1.55 \\
\hline ORPLE12S4 & 1.63 & 1.20 & \\
\hline
\end{tabular}

- Empty data field

* Starting glass for bubbling tests contained no $\mathrm{SO}_{3}$. 
Table 2.45. Results of 7-day PCT (at $90^{\circ} \mathrm{C}$ ) and VHT (at $200^{\circ} \mathrm{C}$ for 24 Days) for Twelve ORPLE Crucible Glasses.

\begin{tabular}{|c|c|c|c|c|c|c|c|c|c|c|c|c|}
\hline Glass ID & ORPLE1 & ORPLE2 & ORPLE3 & ORPLE4 & ORPLE5 & ORPLE6 & ORPLE7 & ORPLE8 & ORPLE9 & ORPLE10 & ORPLE11 & ORPLE12 \\
\hline \multicolumn{13}{|c|}{ 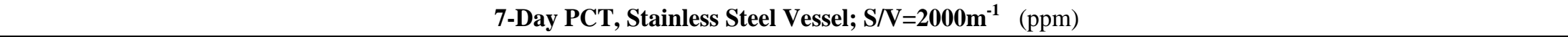 } \\
\hline $\mathrm{B}$ & 16.67 & 25.44 & 21.03 & 16.97 & 21.83 & 13.68 & 13.13 & 7.06 & 9.48 & 14.70 & 9.57 & 15.42 \\
\hline $\mathrm{Na}$ & 152.30 & 108.40 & 119.30 & 140.70 & 213.30 & 108.90 & 102.20 & 90.43 & 89.49 & 87.78 & 81.96 & 94.32 \\
\hline Si & 59.71 & 49.62 & 43.90 & 52.62 & 65.85 & 48.96 & 46.69 & 37.63 & 36.34 & 10.03 & 35.61 & 45.91 \\
\hline \multicolumn{13}{|c|}{ Normalized Concentrations (g/L) } \\
\hline B & 0.54 & 0.71 & 0.59 & 0.56 & 0.73 & 0.45 & 0.43 & 0.24 & 0.34 & 0.45 & 0.31 & 0.50 \\
\hline $\mathrm{Na}$ & 1.28 & 0.91 & 1.01 & 1.05 & 1.44 & 0.92 & 0.86 & 0.76 & 0.75 & 0.74 & 0.69 & 0.79 \\
\hline $\mathrm{Si}$ & 0.31 & 0.27 & 0.25 & 0.28 & 0.35 & 0.25 & 0.24 & 0.19 & 0.19 & 0.05 & 0.18 & 0.24 \\
\hline $\mathrm{pH}$ & 11.48 & 11.18 & 11.34 & 11.48 & 11.61 & 11.39 & 11.32 & 11.34 & 11.38 & 11.25 & 11.34 & 11.32 \\
\hline \multicolumn{13}{|c|}{ 7-Day PCT Normalized Mass Loss (g/m²) } \\
\hline $\mathrm{B}$ & 0.27 & 0.36 & 0.30 & 0.28 & 0.37 & 0.22 & 0.21 & 0.12 & 0.17 & 0.23 & 0.16 & 0.25 \\
\hline $\mathrm{Na}$ & 0.64 & 0.46 & 0.50 & 0.53 & 0.72 & 0.46 & 0.43 & 0.38 & 0.38 & 0.37 & 0.35 & 0.40 \\
\hline $\mathrm{Si}$ & 0.15 & 0.13 & 0.13 & 0.14 & 0.18 & 0.13 & 0.12 & 0.10 & 0.09 & 0.03 & 0.09 & 0.12 \\
\hline \multicolumn{13}{|c|}{ 7-Day PCT Normalized Loss Rate (g/m²/d) } \\
\hline B & 0.04 & 0.05 & 0.04 & 0.04 & 0.05 & 0.03 & 0.03 & 0.02 & 0.02 & 0.03 & 0.02 & 0.04 \\
\hline $\mathrm{Na}$ & 0.09 & 0.07 & 0.07 & 0.08 & 0.10 & 0.07 & 0.06 & 0.05 & 0.05 & 0.05 & 0.05 & 0.06 \\
\hline $\mathrm{Si}$ & 0.02 & 0.02 & 0.02 & 0.02 & 0.03 & 0.02 & 0.02 & 0.01 & 0.01 & 0.00 & 0.01 & 0.02 \\
\hline \multicolumn{13}{|c|}{ VHT Alteration (24 days at $200^{\circ} \mathrm{C}$ ) } \\
\hline $\begin{array}{c}\text { Alteration } \\
\text { Depth }(\mu \mathrm{m})\end{array}$ & 180 & 264 & 171 & 376 & 950 & 221 & 368 & 315 & 248 & 293 & 285 & 277 \\
\hline $\begin{array}{c}\text { Alteration Rate } \\
\left(\mathrm{g} / \mathrm{m}^{2} / \text { day }\right)^{*}\end{array}$ & 19.9 & 29.2 & 18.9 & 41.5 & 104.9 & 24.4 & 40.6 & 34.8 & 27.4 & 32.4 & 31.5 & 30.6 \\
\hline
\end{tabular}

* Alteration rates calculated using estimated density of $2.65 \mathrm{~g} / \mathrm{cc}$ 
Table 2.46. Viscosities and Electrical Conductivities of Twelve ORPLE Crucible Glasses.

\begin{tabular}{|c|c|c|c|c|c|c|c|c|c|c|c|c|}
\hline $\begin{array}{c}\text { Glass } \\
\text { ID }\end{array}$ & ORPLE1 & ORPLE2 & ORPLE3 & ORPLE4 & ORPLE5 & ORPLE6 & ORPLE7 & ORPLE8 & ORPLE9 & ORPLE10 & ORPLE11 & ORPLE12 \\
\hline \multicolumn{13}{|c|}{ Viscosity (poise) } \\
\hline $900^{\circ} \mathrm{C}$ & 294 & 373 & 251 & 327 & 441 & 366 & 517 & 221 & 359 & 285 & 367 & 502 \\
\hline $950^{\circ} \mathrm{C}$ & 149 & 179 & 122 & 157 & 192 & 161 & 193 & 116 & 176 & 150 & 170 & 215 \\
\hline $1000^{\circ} \mathrm{C}$ & 82 & 95 & 67 & 84 & 98 & 81 & 88 & 66 & 94 & 84 & 90 & 106 \\
\hline $1050^{\circ} \mathrm{C}$ & 48 & 55 & 40 & 48 & 56 & 45 & 46 & 40 & 54 & 49 & 52 & 58 \\
\hline $1100^{\circ} \mathrm{C}$ & 30 & 34 & 25 & 30 & 35 & 27 & 27 & 26 & 33 & 31 & 33 & 34 \\
\hline $1150^{\circ} \mathrm{C}$ & 20 & 22 & 17 & 19 & 23 & 17 & 17 & 17 & 22 & 20 & 22 & 22 \\
\hline $1200^{\circ} \mathrm{C}$ & 13 & 15 & 12 & 13 & 16 & 12 & 12 & 12 & 15 & 13 & 15 & 14 \\
\hline $1250^{\circ} \mathrm{C}$ & 9 & 11 & 9 & 9 & 12 & 8 & 9 & 9 & 10 & 9 & 11 & 10 \\
\hline \multicolumn{13}{|c|}{ Electrical Conductivity (S/cm) } \\
\hline $900^{\circ} \mathrm{C}$ & 0.131 & 0.148 & 0.147 & 0.150 & 0.159 & 0.150 & 0.159 & 0.144 & 0.138 & 0.151 & 0.135 & 0.187 \\
\hline $950^{\circ} \mathrm{C}$ & 0.175 & 0.195 & 0.193 & 0.196 & 0.206 & 0.197 & 0.214 & 0.194 & 0.189 & 0.206 & 0.178 & 0.241 \\
\hline $1000^{\circ} \mathrm{C}$ & 0.229 & 0.251 & 0.247 & 0.252 & 0.261 & 0.254 & 0.275 & 0.256 & 0.248 & 0.268 & 0.230 & 0.304 \\
\hline $1050^{\circ} \mathrm{C}$ & 0.294 & 0.316 & 0.310 & 0.318 & 0.326 & 0.320 & 0.341 & 0.330 & 0.313 & 0.337 & 0.291 & 0.376 \\
\hline $1100^{\circ} \mathrm{C}$ & 0.370 & 0.391 & 0.384 & 0.394 & 0.399 & 0.398 & 0.412 & 0.418 & 0.385 & 0.412 & 0.361 & 0.457 \\
\hline $1150^{\circ} \mathrm{C}$ & 0.458 & 0.477 & 0.467 & 0.481 & 0.482 & 0.486 & 0.485 & 0.520 & 0.463 & 0.492 & 0.442 & 0.547 \\
\hline $1200^{\circ} \mathrm{C}$ & 0.559 & 0.573 & 0.562 & 0.579 & 0.575 & 0.587 & 0.561 & 0.639 & 0.546 & 0.576 & 0.533 & 0.647 \\
\hline $1250^{\circ} \mathrm{C}$ & 0.674 & 0.680 & 0.667 & 0.689 & 0.678 & 0.699 & 0.637 & 0.773 & 0.633 & 0.663 & 0.636 & 0.755 \\
\hline
\end{tabular}


Table 2.47. Results of K-3 Corrosion Testing for Ten ORPLE Crucible Glasses.

\begin{tabular}{|c|c|c|c|}
\hline Glass ID & $\begin{array}{c}\text { Neck loss } \\
\text { (inches) }\end{array}$ & $\begin{array}{c}\text { Depth of altered } \\
\text { zone (inches) }\end{array}$ & $\begin{array}{c}\text { Half-down loss } \\
\text { (inches) }\end{array}$ \\
\hline ORPLE1 & 0.059 & 0.028 & 0.003 \\
\hline ORPLE3 & 0.072 & 0.031 & 0.004 \\
\hline ORPLE4 & 0.087 & 0.026 & 0.006 \\
\hline ORPLE6 & 0.054 & 0.028 & 0.006 \\
\hline ORPLE7 & 0.033 & 0.028 & 0.001 \\
\hline ORPLE8 & 0.069 & 0.027 & 0.005 \\
\hline ORPLE9 & 0.048 & 0.027 & 0.004 \\
\hline ORPLE10 & 0.053 & 0.027 & 0.005 \\
\hline ORPLE11 & 0.060 & 0.026 & 0.008 \\
\hline ORPLE12 & 0.031 & 0.030 & 0.001 \\
\hline
\end{tabular}


Table 2.48. Summary of Test Results for Selected ORPLE Glass Formulation ORPLE12 and Comparison to ILAW Requirements.

\begin{tabular}{|c|c|c|}
\hline Test & Requirement [45, 46] & $\begin{array}{c}\text { Test Result for } \\
\text { ORPLE12 }\end{array}$ \\
\hline Density of glass & $<3.7 \mathrm{~g} / \mathrm{cc}$ & Not measured \\
\hline Crystalline Phase & Phase identification & $\begin{array}{c}\text { Clear homogeneous glass } \\
\text { with less than } 0.1 \text { vol\% crystals after } \\
\text { heat treatment at } 850^{\circ} \mathrm{C} \text { for } 20 \text { hours }\end{array}$ \\
\hline Liquidus & $<950^{\circ} \mathrm{C}$ & Not measured \\
\hline Centerline Canister Cooling & Phase identification & $0.25 \mathrm{~g} / \mathrm{m}^{2}$ \\
\hline PCT B $\left(\mathrm{g} / \mathrm{m}^{2}\right)$ & $<2.0 \mathrm{~g} / \mathrm{m}^{2}$ & $0.40 \mathrm{~g} / \mathrm{m}^{2}$ \\
\hline PCT Na $\left(\mathrm{g} / \mathrm{m}^{2}\right)$ & $<2.0 \mathrm{~g} / \mathrm{m}^{2}$ & $0.12 \mathrm{~g} / \mathrm{m}^{2}$ \\
\hline PCT Si $\left(\mathrm{g} / \mathrm{m}^{2}\right)$ & $<2.0 \mathrm{~g} / \mathrm{m}^{2}$ & $31 \mathrm{~g} / \mathrm{m}^{2} / \mathrm{day}$ \\
\hline VHT at $200^{\circ} \mathrm{C}\left(\mathrm{g} / \mathrm{m}^{2} / \mathrm{day}\right)$ & $<50 \mathrm{~g} / \mathrm{m}^{2} / \mathrm{day}$ & $34 \mathrm{P}$ \\
\hline Viscosity (poise) at $1100^{\circ} \mathrm{C}$ & 10 to $150 \mathrm{P}$ & $0.457 \mathrm{~S} / \mathrm{cm}$ \\
\hline Conductivity (S/cm) at $1100^{\circ} \mathrm{C}$ & 0.2 to $0.7 \mathrm{~S} / \mathrm{cm}$ & Not measured \\
\hline T $\left({ }^{\circ} \mathrm{C}\right)$ & Report for modeling & \\
\hline
\end{tabular}


Table 2.49. Oxide Composition of AZ-101 Simulant and ORPLE12 Glass Composition Used in Melter Tests (wt\%).

\begin{tabular}{|c|c|c|c|}
\hline Component & AZ-101 waste contribution & $\begin{array}{c}\text { Glass former } \\
\text { additives }\end{array}$ & $\begin{array}{c}\text { ORPLE12 } \\
\text { (for AZ-101) }\end{array}$ \\
\hline Loading & $19.8 \%$ & $80.2 \%$ & - \\
\hline $\mathrm{Al}_{2} \mathrm{O}_{3}$ & 1.161 & 6.41 & 7.58 \\
\hline $\mathrm{B}_{2} \mathrm{O}_{3}$ & - & 9.82 & 9.82 \\
\hline $\mathrm{CaO}$ & - & 10.02 & 10.02 \\
\hline $\mathrm{Cr}_{2} \mathrm{O}_{3}$ & 0.102 & 0.40 & 0.50 \\
\hline $\mathrm{Cs}_{2} \mathrm{O}$ & 0.150 & - & 0.15 \\
\hline $\mathrm{Fe}_{2} \mathrm{O}_{3}$ & - & 0.24 & 0.24 \\
\hline $\mathrm{K}_{2} \mathrm{O}$ & 0.545 & - & 0.55 \\
\hline $\mathrm{Li}_{2} \mathrm{O}$ & - & 2.49 & 2.49 \\
\hline $\mathrm{MgO}_{\mathrm{Na}_{2} \mathrm{O}^{(\mathrm{a})}}$ & - & 1.04 & 1.04 \\
\hline $\mathrm{SiO}_{2}$ & $15.806+0.194^{(1)}$ & - & 16.00 \\
\hline $\mathrm{TiO}_{2}$ & 0.015 & 41.26 & 41.27 \\
\hline $\mathrm{V}_{2} \mathrm{O}_{5}$ & & 0.01 & 0.01 \\
\hline $\mathrm{ZnO}_{\mathrm{ZnO}}$ & - & 1.74 & 1.74 \\
\hline $\mathrm{Zl}_{2}$ & - & 3.21 & 3.21 \\
\hline $\mathrm{Cl}$ & - & 3.53 & 3.53 \\
\hline $\mathrm{P}_{2} \mathrm{O}_{5}$ & 0.025 & - & 0.02 \\
\hline $\mathrm{SO}_{3}{ }^{(b)}$ & 0.204 & - & 0.20 \\
\hline $\mathrm{SUM}^{\mathrm{bu}}$ & 0.123 & - & 0.12 \\
\hline
\end{tabular}

(a) Simulant was ordered at a concentration of $15.81 \mathrm{wt} \% \mathrm{Na}_{2} \mathrm{O}$ and modified before each melter test with (1) $\mathrm{Na}_{2} \mathrm{SO}_{4}$ and (2) $\mathrm{NaOH}$ additions to obtain $16.00 \mathrm{wt} \% \mathrm{Na}_{2} \mathrm{O}$ in the glass.

(b) Concentration of $\mathrm{SO}_{3}$ was increased in steps during the melter tests from $1.25 \mathrm{wt} \% \mathrm{SO}_{3}$ in the glass up to $1.75 \mathrm{wt} \%$.

- Empty data field 
Table 2.50a. Glass Former Additives for 1 Liter of LAW AZ-101 Simulant (7 M Na) and Corresponding Melter Feed Properties.

\begin{tabular}{|c|c|}
\hline Additives Source & Feed ORPLE12 \\
\hline Additives in Glass (wt\%) & 80.17 \\
\hline Kyanite $\left(\mathrm{Al}_{2} \mathrm{SiO}_{5}\right) 325$ Mesh (Kyanite Mining) (g) & 147.81 \\
\hline $\mathrm{H}_{3} \mathrm{BO}_{3}$ (US Borax - Technical Granular) (g) & 236.52 \\
\hline Wollanstonite NYAD 325 Mesh (NYCO Minerals) (g) & 298.96 \\
\hline $\mathrm{Cr}_{2} \mathrm{O}_{3}$ oxide & $5.55^{(1)}$ \\
\hline $\mathrm{Fe}_{2} \mathrm{O}_{3}$ (Prince Manufacturing) (g) & 0.29 \\
\hline $\mathrm{Li}_{2} \mathrm{CO}_{3}$ (Chemetall Foote Co, Tech Grade) & 84.35 \\
\hline Olivine $\left(\mathrm{Mg}_{2} \mathrm{SiO}_{4}\right) 325$ Mesh (\#180 Unimin) (g) & 24.58 \\
\hline $\mathrm{SiO}_{2}$ (Sil-co-Sil 75 US Silica) (g) & 305.82 \\
\hline $\mathrm{V}_{2} \mathrm{O}_{5}$ - Pulva Ground - Stratcor & 25.09 \\
\hline ZnO (KADOX - 920 Zinc Corp. of America) (g) & 43.48 \\
\hline Zircon $\mathrm{ZrSiO}_{4}$ (Flour) Mesh 325 (AM. Mineral) (g) & 72.14 \\
\hline Supplemental $\mathrm{Na}_{2} \mathrm{SO}_{4}$ & Variable - Table 2.50b \\
\hline Addition of Sucrose as Reductant (g) & 62.48 \\
\hline Simulant Weight for 1 liter (g) & 1286 \\
\hline Sum of Additives (g) & 1307 \\
\hline Sum of Complete Batch (g) & 2593 \\
\hline Target Final Volume (l) & 1.53 \\
\hline Estimated Density (g/ml) & 1.70 \\
\hline Target Glass Produced (g) & 1356 \\
\hline Target Weight \% Additives in Slurry & 50 \\
\hline Target Glass Yield (g/kg of Feed) & 523 \\
\hline Target Glass Yield (g/l of Feed) & 889 \\
\hline Target Total Solids (g/l of Feed) & 1185 \\
\hline Target Additives (g/l of Feed) & 857 \\
\hline
\end{tabular}

${ }^{(1)}$ Note that a $\mathrm{Cr}_{2} \mathrm{O}_{3}$ addition was cut down by $50 \%$ to account for K3-brick contribution.

Table 2.50b. $\mathrm{NaOH}$ and $\mathrm{Na}_{2} \mathrm{SO}_{4}$ Additions Required to Obtain 16 wt \% $\mathrm{Na}_{2} \mathrm{O}$ and Various $\mathrm{SO}_{3}$ Concentrations Ranging from 1.25 to $1.75 \mathrm{wt} \%$ in the ORPLE12 Glass.

\begin{tabular}{|c|c|c|}
\hline $\begin{array}{c}\text { Final } \\
\mathrm{SO}_{3} \mathrm{wt} \%\end{array}$ & $\begin{array}{c}\text { NaOH needed } \\
\text { per kg of feed } \\
\text { (grams) }\end{array}$ & $\begin{array}{c}\mathrm{Na}_{2} \mathrm{SO}_{4} \text { needed } \\
\text { per kg of feed } \\
\text { (grams) }\end{array}$ \\
\hline 1.25 & 11.0 & 0 \\
\hline 1.50 & 8.81 & 2.38 \\
\hline 1.625 & 7.48 & 3.58 \\
\hline 1.75 & 6.64 & 4.78 \\
\hline
\end{tabular}


Table 2.51. Characteristics of Melter Feed Samples During DM10 ORP LAW Tests.

\begin{tabular}{|c|c|c|c|c|c|c|c|c|c|}
\hline \multirow{2}{*}{$\begin{array}{l}\text { Tank Waste/ } \\
\text { Sub-Envelope } \\
\text { Identification }\end{array}$} & \multirow{2}{*}{ Test } & \multirow{2}{*}{ Region } & \multirow[b]{2}{*}{ Date } & \multirow[b]{2}{*}{ Name } & \multirow{2}{*}{$\%$ Water } & \multirow{2}{*}{$\begin{array}{c}\text { Density } \\
(\mathrm{g} / \mathrm{ml})\end{array}$} & \multicolumn{2}{|c|}{ Glass Yield } & \multirow{2}{*}{ pH } \\
\hline & & & & & & & $(\mathrm{kg} / \mathrm{kg})$ & $(g / l)$ & \\
\hline \multirow{3}{*}{$\begin{array}{c}\text { AZ-101/ } \\
\text { Sub-Envelope B1 }\end{array}$} & 1 & $\mathbf{E}$ & $1 / 25 / 2007$ & Q10-F-134A & 38.95 & 1.68 & 0.504 & 847 & 10.98 \\
\hline & \multicolumn{4}{|c|}{ Average (LAWB83) [23] } & 40.65 & 1.71 & 0.521 & 888 & 8.57 \\
\hline & \multicolumn{4}{|c|}{ (LAWB83) [18] } & 38.77 & 1.71 & 0.526 & 899 & 7.49 \\
\hline \multirow{5}{*}{$\begin{array}{c}\text { AN-105/ } \\
\text { Sub-Envelope A1 }\end{array}$} & 2 & A & $6 / 6 / 2007$ & R10-F-95A & 42.08 & 1.61 & 0.441 & 712 & 13.59 \\
\hline & \multicolumn{4}{|c|}{ Average ( LAWA187) [6] } & 42.37 & 1.64 & 0.442 & 725 & 11.83 \\
\hline & \multicolumn{4}{|c|}{ Average ( LAWA161) [2] } & 38.70 & 1.68 & 0.472 & 791 & 11.50 \\
\hline & \multicolumn{4}{|c|}{ High Temperature Test Average [3] } & 38.40 & 1.69 & 0.467 & 788 & 11.96 \\
\hline & \multicolumn{4}{|c|}{ DM1200 Average [48] } & 37.60 & 1.72 & 0.481 & 827 & 12.19 \\
\hline \multirow{3}{*}{$\begin{array}{c}\text { AN-107/ } \\
\text { Sub-Envelope C1 }\end{array}$} & 3 & $\mathbf{B}$ & $6 / 15 / 2007$ & S10-F-9A & 41.12 & 1.66 & 0.465 & 772 & 12.88 \\
\hline & \multicolumn{4}{|c|}{ Average (LAWC22) [22] } & 39.83 & 1.67 & 0.493 & 826 & 11.35 \\
\hline & \multicolumn{4}{|c|}{ DM1200 [49] } & 38.5 & 1.69 & 0.485 & 821 & 8.95 \\
\hline \multirow{3}{*}{$\begin{array}{c}\text { AN-104/ } \\
\text { Sub-Envelope A3 }\end{array}$} & 4 & $\mathbf{C}$ & $7 / 3 / 2007$ & S10-F-73A & 40.79 & 1.63 & 0.447 & 729 & 9.89 \\
\hline & \multicolumn{4}{|c|}{ Average (LAWA137) [24] } & 37.55 & 1.70 & 0.480 & 815 & 9.65 \\
\hline & \multicolumn{4}{|c|}{ Average (variation study) [17] } & 37.5 & 1.64 & 0.474 & 779 & 9.34 \\
\hline \multirow{5}{*}{$\begin{array}{c}\text { AN-102/ } \\
\text { Sub-Envelope C2 }\end{array}$} & \multirow{2}{*}{5} & \multirow{2}{*}{ D } & $7 / 10 / 2007$ & S10-F-136A & 37.16 & 1.70 & 0.511 & 869 & 6.60 \\
\hline & & & $7 / 18 / 2007$ & T10-F-23A & 38.02 & 1.70 & 0.498 & 847 & 7.09 \\
\hline & \multicolumn{4}{|c|}{ Average (LAWC100) [5] } & 40.8 & 1.66 & 0.461 & 764 & 7.03 \\
\hline & \multicolumn{4}{|c|}{ Average (LAWC35) [24] } & 37.97 & 1.69 & 0.499 & 844 & 8.19 \\
\hline & \multicolumn{4}{|c|}{ Average (variation study) [21] } & 39.31 & 1.68 & 0.496 & 831 & 9.07 \\
\hline
\end{tabular}


Table 2.52. Compositions of Vitrified Melter Feed Samples During DM10 ORP LAW Tests (wt\%).

\begin{tabular}{|c|c|c|c|c|c|c|c|c|c|c|c|c|c|c|c|}
\hline Region & \multicolumn{3}{|c|}{$\mathbf{E}$} & \multicolumn{3}{|c|}{ A } & \multicolumn{3}{|c|}{$\mathbf{B}$} & \multicolumn{3}{|c|}{$\mathbf{C}$} & \multicolumn{3}{|c|}{ D } \\
\hline Test & \multicolumn{3}{|c|}{1} & \multicolumn{3}{|c|}{2} & \multicolumn{3}{|c|}{3} & \multicolumn{3}{|c|}{4} & \multicolumn{3}{|c|}{5} \\
\hline Name & \multicolumn{3}{|c|}{ Q10-F-134A } & \multicolumn{3}{|c|}{ R10-F-95A } & \multicolumn{3}{|c|}{ S10-F-9A } & \multicolumn{3}{|c|}{ S10-F-73A } & \multicolumn{3}{|c|}{ T10-F-23A } \\
\hline Constituent & Target & XRF & \%Dev. & Target & XRF & \%Dev. & Target & XRF & \%Dev. & Target & XRF & \%Dev. & Target & XRF & \%Dev. \\
\hline $\mathrm{Al}_{2} \mathrm{O}_{3}$ & 7.57 & 7.10 & -6.28 & 9.51 & 9.63 & 1.26 & 10.02 & 10.08 & 0.57 & 10.01 & 10.61 & 6.01 & 10.12 & 9.62 & -4.90 \\
\hline $\mathrm{B}_{2} \mathrm{O}_{3}$ & 9.82 & 9.82* & $\mathrm{NC}$ & 8.65 & $8.65 *$ & $\mathrm{NC}$ & 8.51 & $8.51^{*}$ & $\mathrm{NC}$ & 8.49 & $8.49 *$ & $\mathrm{NC}$ & 11.99 & 11.99* & $\mathrm{NC}$ \\
\hline $\mathrm{CaO}$ & 10.02 & 10.41 & 3.82 & 3.34 & 3.33 & -0.29 & 1.90 & 2.01 & 5.76 & 1.90 & 1.91 & 0.21 & 7.99 & 7.89 & -1.18 \\
\hline $\mathrm{Cl}$ & 0.02 & $<0.01$ & $\mathrm{NC}$ & 0.68 & 0.27 & $\mathrm{NC}$ & 0.11 & 0.05 & $\mathrm{NC}$ & 0.62 & 0.25 & $\mathrm{NC}$ & 0.33 & 0.02 & $\mathrm{NC}$ \\
\hline $\mathrm{Cr}_{2} \mathrm{O}_{3}$ & 0.50 & 0.38 & $\mathrm{NC}$ & 0.50 & 0.34 & $\mathrm{NC}$ & 0.53 & 0.06 & $\mathrm{NC}$ & 0.53 & 0.09 & $\mathrm{NC}$ & 0.50 & 0.35 & $\mathrm{NC}$ \\
\hline $\mathrm{Cs}_{2} \mathrm{O}$ & 0.15 & 0.17 & $\mathrm{NC}$ & 0.15 & 0.07 & $\mathrm{NC}$ & 0.14 & 0.08 & $\mathrm{NC}$ & 0.14 & 0.10 & $\mathrm{NC}$ & 0.13 & 0.08 & $\mathrm{NC}$ \\
\hline$F$ & 0.20 & $0.20 *$ & $\mathrm{NC}$ & $\S$ & $<0.01 *$ & $\mathrm{NC}$ & 0.47 & $0.47^{*}$ & $\mathrm{NC}$ & 0.01 & $0.01 *$ & $\mathrm{NC}$ & 0.17 & $0.17 *$ & $\mathrm{NC}$ \\
\hline $\mathrm{Fe}_{2} \mathrm{O}_{3}$ & 0.24 & 0.28 & $\mathrm{NC}$ & 0.93 & 1.00 & $\mathrm{NC}$ & 0.96 & 1.15 & $\mathrm{NC}$ & 0.97 & 1.03 & $\mathrm{NC}$ & 1.00 & 1.07 & 7.30 \\
\hline I & $\S$ & $<0.01$ & $\mathrm{NC}$ & $\S$ & 0.09 & NC & $\S$ & 0.03 & $\mathrm{NC}$ & $\S$ & 0.04 & $\mathrm{NC}$ & $\S$ & $<0.01$ & $\mathrm{NC}$ \\
\hline $\mathrm{K}_{2} \mathrm{O}$ & 0.54 & 0.60 & $\mathrm{NC}$ & 0.54 & 0.53 & $\mathrm{NC}$ & 0.11 & 0.31 & $\mathrm{NC}$ & 0.54 & 0.53 & $\mathrm{NC}$ & 0.16 & 0.34 & $\mathrm{NC}$ \\
\hline $\mathrm{Li}_{2} \mathrm{O}$ & 2.49 & $2.49 *$ & $\mathrm{NC}$ & $\S$ & $<0.01 *$ & $\mathrm{NC}$ & $\S$ & $<0.01^{*}$ & $\mathrm{NC}$ & $\S$ & $<0.01 *$ & $\mathrm{NC}$ & $\S$ & $<0.01 *$ & $\mathrm{NC}$ \\
\hline $\mathrm{MgO}$ & 1.04 & 0.63 & -39.78 & 0.93 & 0.98 & $\mathrm{NC}$ & 0.93 & 1.06 & $\mathrm{NC}$ & 0.93 & 1.01 & $\mathrm{NC}$ & 1.00 & 0.92 & -7.49 \\
\hline $\mathrm{MnO}$ & $\S$ & 0.01 & $\mathrm{NC}$ & $\S$ & 0.01 & $\mathrm{NC}$ & 0.05 & 0.04 & $\mathrm{NC}$ & $\S$ & $<0.01$ & $\mathrm{NC}$ & $\S$ & 0.01 & $\mathrm{NC}$ \\
\hline $\mathrm{Na}_{2} \mathrm{O}$ & 16.00 & 17.21 & 7.58 & 24.00 & 24.25 & 1.02 & 24.00 & 22.55 & -6.07 & 23.57 & 22.39 & -5.00 & 21.00 & 17.50 & -16.68 \\
\hline $\mathrm{NiO}$ & $\S$ & 0.00 & $\mathrm{NC}$ & $\S$ & 0.01 & $\mathrm{NC}$ & 0.04 & 0.05 & $\mathrm{NC}$ & $\S$ & 0.01 & $\mathrm{NC}$ & 0.04 & 0.04 & $\mathrm{NC}$ \\
\hline $\mathrm{P}_{2} \mathrm{O}_{5}$ & 0.12 & 0.17 & $\mathrm{NC}$ & $\S$ & 0.02 & $\mathrm{NC}$ & 0.22 & 0.29 & $\mathrm{NC}$ & 0.18 & 0.27 & NC & 0.28 & 0.34 & $\mathrm{NC}$ \\
\hline $\mathrm{PbO}$ & $\S$ & $<0.01$ & $\mathrm{NC}$ & $\S$ & 0.01 & $\mathrm{NC}$ & $\S$ & $<0.01$ & $\mathrm{NC}$ & $\S$ & $<0.01$ & $\mathrm{NC}$ & 0.01 & 0.01 & $\mathrm{NC}$ \\
\hline $\mathrm{SiO}_{2}$ & 41.28 & 40.73 & -1.32 & 39.52 & 39.44 & -0.19 & 40.01 & 41.18 & 2.92 & 39.95 & 41.89 & 4.86 & 37.01 & 41.94 & 13.33 \\
\hline $\mathrm{SnO}_{2}$ & $\S$ & $<0.01$ & $\mathrm{NC}$ & 2.75 & 3.22 & 16.90 & 1.00 & 1.22 & 21.97 & 1.00 & 1.13 & 13.84 & $\S$ & 0.01 & $\mathrm{NC}$ \\
\hline $\mathrm{SO}_{3}$ & 1.50 & 1.23 & -18.04 & 0.10 & 0.14 & $\mathrm{NC}$ & 0.60 & 0.05 & $\mathrm{NC}$ & 0.80 & 0.02 & $\mathrm{NC}$ & 1.30 & 0.48 & -63.43 \\
\hline $\mathrm{TiO}_{2}$ & 0.01 & 0.15 & $\mathrm{NC}$ & $\S$ & 0.11 & $\mathrm{NC}$ & $\S$ & 0.25 & $\mathrm{NC}$ & $\S$ & 0.12 & $\mathrm{NC}$ & $\S$ & 0.20 & $\mathrm{NC}$ \\
\hline $\mathrm{V}_{2} \mathrm{O}_{5}$ & 1.74 & 2.12 & 21.79 & $\S$ & $<0.01$ & $\mathrm{NC}$ & 2.00 & 2.22 & 10.97 & 1.99 & 2.18 & 9.30 & 1.00 & 1.08 & 8.15 \\
\hline $\mathrm{ZnO}$ & 3.21 & 3.36 & 4.71 & 2.45 & 2.49 & 1.47 & 2.37 & 2.46 & 3.77 & 2.36 & 2.39 & 1.17 & 2.99 & 3.06 & 2.39 \\
\hline $\mathrm{ZrO}_{2}$ & 3.53 & 2.94 & -16.71 & 5.95 & 5.41 & -9.07 & 6.03 & 5.90 & -2.18 & 6.02 & 5.53 & -8.10 & 2.99 & 2.88 & -3.72 \\
\hline Sum & 100.00 & 100.00 & $\mathrm{NC}$ & 100.00 & 100.00 & $\mathrm{NC}$ & 100.00 & 100.00 & $\mathrm{NC}$ & 100.00 & 100.00 & $\mathrm{NC}$ & 100.00 & 100.00 & $\mathrm{NC}$ \\
\hline
\end{tabular}

* - Target values; § - Not a target constituent; NC - not calculated 
Table 3.1. Summary of Region E Test Conditions and Results.

\begin{tabular}{|c|c|c|c|c|c|c|}
\hline \multicolumn{7}{|c|}{ Tank Waste/Sub-Envelope Identification: AZ-101/Sub-Envelope B1 } \\
\hline \multicolumn{7}{|c|}{$\mathrm{Na}_{2} \mathrm{O}$ wt.\%: Test Plan Target -16.0 , Melter Glass Target -16.0} \\
\hline \multicolumn{7}{|c|}{ Target Minimum $\mathrm{SO}_{3}$ Concentration in Glass, wt\%: 1.25} \\
\hline \multicolumn{2}{|c|}{ Test Segment } & $1 \mathrm{~A}$ & 1B & $1 \mathrm{C}$ & 1D & $1 \mathrm{E}$ \\
\hline \multirow{4}{*}{ Time } & Feed Start & $1 / 23 / 07$ & $1 / 24 / 07$ & $1 / 25 / 07$ & $1 / 25 / 07$ & $1 / 26 / 07$ \\
\hline & & $\frac{11.4 \mathrm{~J}}{1 / 24 / 07}$ & $\frac{3.00}{1 / 24 / 07}$ & $\frac{0.50}{1 / 25 / 07}$ & 10.00 & $\frac{0.00}{1 / 26 / 07}$ \\
\hline & Feed End & $7: 30$ & 23:00 & $14: 27$ & $5: 00$ & $19: 20$ \\
\hline & Net Slurry Feeding (hr) & 13.9 & 13.5 & 13.9 & 13.0 & 12.8 \\
\hline \multirow{2}{*}{ Feed } & $\mathrm{wt} \% \mathrm{SO}_{3}$ as glass & 1.25 & 1.50 & 1.50 & 1.75 & 1.625 \\
\hline & Feed Used (kg) & 49.0 & 51.1 & 52.2 & 47.1 & 47.3 \\
\hline \multicolumn{2}{|c|}{ Average Production Rate $\left(\mathrm{kg} / \mathrm{m}^{2} / \text { day }\right)^{*}$} & 2110 & 2249 & 2232 & 2153 & 2196 \\
\hline \multicolumn{2}{|c|}{ Average Bubbling Rate (lpm) } & 1.8 & 1.9 & 2.3 & 2.5 & 2.6 \\
\hline \multirow{5}{*}{$\begin{array}{c}\text { Average } \\
\text { Temperatures } \\
\left({ }^{\circ} \mathrm{C}\right)\end{array}$} & Glass, 2” from floor & 1152 & 1153 & 1153 & 1151 & 1152 \\
\hline & Glass, 4” from floor & 1122 & 1116 & 1126 & 1131 & 1127 \\
\hline & Electrode & 1090 & 1085 & 1090 & 1100 & 1097 \\
\hline & Plenum, thermowell & 494 & 508 & 519 & 564 & 555 \\
\hline & Plenum, exposed & 464 & 490 & 486 & 548 & 542 \\
\hline \multirow{3}{*}{ Product } & $\begin{array}{l}\text { Secondary Phases on Melt } \\
\text { Surface at Test End }\end{array}$ & Yes & Yes & No & Yes & Yes \\
\hline & Measured wt $\% \mathrm{SO}_{3}$ & 1.06 & 1.40 & 1.38 & 1.59 & 1.65 \\
\hline & $\begin{array}{l}\text { \% Feed Sulfur in Glass } \\
\text { Product }\end{array}$ & 85 & 93 & 92 & 91 & 102 \\
\hline \multirow{4}{*}{$\begin{array}{c}\text { Average } \\
\text { Concentrations } \\
\text { monitored in } \\
\text { stack exhaust by } \\
\text { FTIR (ppmv) }\end{array}$} & NO & 289 & 294 & 281 & 290 & 291 \\
\hline & $\mathrm{NO}_{2}$ & 29.0 & 24.1 & 24.8 & 22.6 & 23.4 \\
\hline & $\mathrm{CO}$ & 5.6 & 5.4 & 5.8 & 6.8 & 6.6 \\
\hline & $\mathrm{NH}_{3}$ & 42.5 & 41.4 & 44.6 & 38.5 & 39.8 \\
\hline
\end{tabular}

* - Glass production rates calculated from feed data 
The Catholic University of America Vitreous State Laboratory
Enhanced LAW Glass Formulation Testing Final Report, VSL-07R1130-1, Rev. 0

Table 3.2. Summary of Region A Test Conditions and Results.

\begin{tabular}{|c|c|c|c|c|c|c|}
\hline \multicolumn{7}{|c|}{ Tank Waste/Sub-Envelope Identification: AN-105/Sub-Envelope A1 } \\
\hline \multicolumn{7}{|c|}{$\mathrm{Na}_{2} \mathrm{O}$ wt.\%: Test Plan Target -25.0 , Melter Glass Target -24.0} \\
\hline \multicolumn{7}{|c|}{ Target Minimum $\mathrm{SO}_{3}$ Concentration in Glass, wt\%: 0} \\
\hline \multicolumn{2}{|c|}{ Test Segment } & $2 \mathrm{~A}$ & 2B & $2 \mathrm{C}$ & 2D & $2 \mathrm{E}$ \\
\hline \multirow{4}{*}{ Time } & Feed Start & 6/6/07 & $6 / 6 / 07$ & $6 / 7 / 07$ & $6 / 8 / 07$ & $6 / 11 / 07$ \\
\hline & & $6 / 6 / 07$ & $6 / 7 / 07$ & $6 / 8 / 07$ & $6 / 8 / 07$ & $6 / 12 / 07$ \\
\hline & гееप Бाव & 21:45 & $12: 00$ & $4: 40$ & $22: 00$ & 9:11 \\
\hline & Net Slurry Feeding (hr) & 14.3\# & 13.0 & 15.4 & 15.7@ & 12.5 \\
\hline \multirow{2}{*}{ Feed } & $\mathrm{wt} \% \mathrm{SO}_{3}$ as glass & 0.1 & 0.2 & 0.3 & 0.4 & 0.5 \\
\hline & Feed Used (kg) & 34.6 & 52.9 & 53.7 & 52.4 & 46.4 \\
\hline \multicolumn{2}{|c|}{ Average Production Rate $\left(\mathrm{kg} / \mathrm{m}^{2} / \text { day }\right)^{*}$} & 1300 & 2186 & 1883 & 1793 & 1994 \\
\hline \multicolumn{2}{|c|}{ Average Bubbling Rate (lpm) } & 2.3 & 4.5 & 6.3 & 5.6 & 6.4 \\
\hline \multirow{5}{*}{$\begin{array}{c}\text { Average } \\
\text { Temperatures } \\
\left({ }^{\circ} \mathrm{C}\right)\end{array}$} & Glass, 2” from floor & 1148 & 1150 & 1151 & 1148 & 1150 \\
\hline & Glass, 4” from floor & 1107 & 1145 & 1150 & 1135 & 1147 \\
\hline & Electrode & 1097 & 1080 & 1072 & 1055 & 1089 \\
\hline & Plenum, thermowell & 581 & 363 & 580 & 514 & 509 \\
\hline & Plenum, exposed & 531 & 349 & 499 & 466 & 475 \\
\hline \multirow{3}{*}{ Product } & $\begin{array}{l}\text { Secondary Phases on Melt } \\
\text { Surface at Test End }\end{array}$ & No & No & No & No & No \\
\hline & Measured wt $\% \mathrm{SO}_{3}$ & 0.10 & 0.19 & 0.29 & 0.37 & 0.50 \\
\hline & $\begin{array}{c}\text { \% Feed Sulfur in Glass } \\
\text { Product }\end{array}$ & 100 & 95 & 97 & 93 & 100 \\
\hline \multirow{4}{*}{$\begin{array}{c}\text { Average } \\
\text { Concentrations } \\
\text { monitored in } \\
\text { stack exhaust by } \\
\text { FTIR (ppmv) }\end{array}$} & NO & 577 & 530 & 494 & 496 & NM \\
\hline & $\mathrm{NO}_{2}$ & 87.1 & 96.2 & 72.5 & 75.2 & NM \\
\hline & $\mathrm{CO}$ & 25.8 & 17.6 & 18.5 & 16.2 & NM \\
\hline & $\mathrm{NH}_{3}$ & 11.2 & 26.5 & 26.4 & 30.9 & NM \\
\hline
\end{tabular}

* - Glass production rates calculated from feed data

\# - Net time reflects the total time interval including half hour down time.

@ - Net time reflects the total time interval including 112 minute down time.

NM - Not Measured. 
The Catholic University of America Vitreous State Laboratory
Enhanced LAW Glass Formulation Testing Final Report, VSL-07R1130-1, Rev. 0

Table 3.2. Summary of Region A Test Conditions and Results (continued).

\begin{tabular}{|c|c|c|}
\hline \multicolumn{3}{|c|}{ Tank Waste/Sub-Envelope Identification: AN-105/Sub-Envelope A1 } \\
\hline \multicolumn{3}{|c|}{$\mathrm{Na}_{2} \mathrm{O}$ wt.\%: Test Plan Target - 25.0, Melter Glass Target -24.0} \\
\hline \multicolumn{3}{|c|}{ Target Minimum $\mathrm{SO}_{3}$ Concentration in Glass, wt\%: 0} \\
\hline \multicolumn{2}{|l|}{ Test Segment } & $2 \mathrm{~F}$ \\
\hline \multirow{4}{*}{ Time } & Feed Start & $\begin{array}{c}6 / 14 / 07 \\
10.25\end{array}$ \\
\hline & Feed End & 6/15/07 \\
\hline & Геटи Бाप & 4:07 \\
\hline & Net Slurry Feeding (hr) & $17.7^{@}$ \\
\hline \multirow{2}{*}{ Feed } & $\mathrm{wt} \% \mathrm{SO}_{3}$ as glass & 0.6 \\
\hline & Feed Used (kg) & 50.8 \\
\hline \multicolumn{2}{|c|}{ Average Production Rate $\left(\mathrm{kg} / \mathrm{m}^{2} / \mathrm{day}\right)^{*}$} & 1542 \\
\hline \multicolumn{2}{|c|}{ Average Bubbling Rate (lpm) } & 6.5 \\
\hline \multirow{5}{*}{ Average Temperatures $\left({ }^{\circ} \mathrm{C}\right)$} & Glass, 2" from floor & 1150 \\
\hline & Glass, 4" from floor & 1129 \\
\hline & Electrode & 1043 \\
\hline & Plenum, thermowell & 521 \\
\hline & Plenum, exposed & 527 \\
\hline \multirow{3}{*}{ Product } & $\begin{array}{l}\text { Secondary Phases on Melt Surface at } \\
\text { Test End }\end{array}$ & No \\
\hline & Measured $\mathrm{wt} \% \mathrm{SO}_{3}$ & 0.52 \\
\hline & \% Feed Sulfur in Glass Product & 87 \\
\hline \multirow{4}{*}{$\begin{array}{l}\text { Average Concentrations monitored in stack exhaust by FTIR } \\
\text { (ppmv) }\end{array}$} & NO & 371 \\
\hline & $\mathrm{NO}_{2}$ & 68.6 \\
\hline & $\mathrm{CO}$ & 13.0 \\
\hline & $\mathrm{NH}_{3}$ & 2.8 \\
\hline
\end{tabular}

* - Glass production rates calculated from feed data

@ - Net time reflects the total time interval including 168 minute down time. 
Table 3.3. Summary of Region B Test Conditions and Results.

\begin{tabular}{|c|c|c|c|c|c|}
\hline \multicolumn{6}{|c|}{ Tank Waste/Sub-Envelope Identification: AN-107/Sub-Envelope C1 } \\
\hline \multicolumn{6}{|c|}{$\mathrm{Na}_{2} \mathrm{O}$ wt.\%: Test Plan Target -25.0 , Melter Glass Target -24.0} \\
\hline \multicolumn{6}{|c|}{ Target Minimum $\mathrm{SO}_{3}$ Concentration in Glass, wt\%: 0.35} \\
\hline \multicolumn{2}{|c|}{ Test Segment } & $3 \mathrm{~A}$ & 3B & $3 \mathrm{C}$ & 3D \\
\hline \multirow{5}{*}{ Time } & \multirow{2}{*}{ Feed Start } & $6 / 15 / 07$ & 6/28/07 & $6 / 29 / 07$ & $7 / 2 / 07$ \\
\hline & & $7: 00$ & $17: 10$ & $15: 30$ & $7: 50$ \\
\hline & \multirow{2}{*}{ Feed End } & $6 / 15 / 07$ & $6 / 29 / 07$ & $6 / 30 / 07$ & $7 / 2 / 07$ \\
\hline & & $20: 30$ & 10:12 & 4:31 & 20:00 \\
\hline & Net Slurry Feeding (hr) & 13.5 & 17.0@ & 13.0 & 12.2 \\
\hline \multirow{2}{*}{ Feed } & $\mathrm{wt} \% \mathrm{SO}_{3}$ as glass & 0.6 & 0.7 & 0.85 & 1.0 \\
\hline & Feed Used (kg) & 48.9 & 53.2 & 51.4 & 52.6 \\
\hline \multicolumn{2}{|c|}{ Average Production Rate $\left(\mathrm{kg} / \mathrm{m}^{2} / \text { day }\right)^{*}$} & 1946 & 1681 & 2124 & 2316 \\
\hline \multicolumn{2}{|c|}{ Average Bubbling Rate (lpm) } & 5.6 & 3.2 & 5.2 & 5.1 \\
\hline \multirow{5}{*}{$\begin{array}{c}\text { Average } \\
\text { Temperatures } \\
\left({ }^{\circ} \mathrm{C}\right)\end{array}$} & Glass, 2” from floor & 1150 & 1148 & 1142 & 1130 \\
\hline & Glass, 4” from floor & 1145 & 1143 & 1135 & 1125 \\
\hline & Electrode & 1062 & 1086 & 1082 & 1074 \\
\hline & Plenum, thermowell & 457 & 547 & 483 & 492 \\
\hline & Plenum, exposed & 430 & 537 & 476 & 498 \\
\hline \multirow{3}{*}{ Product } & $\begin{array}{l}\text { Secondary Phases on Melt } \\
\text { Surface at Test End }\end{array}$ & No & No & No & Yes \\
\hline & Measured wt $\% \mathrm{SO}_{3}$ & 0.6 & 0.68 & 0.81 & 1.0 \\
\hline & $\begin{array}{l}\text { \% Feed Sulfur in Glass } \\
\text { Product }\end{array}$ & 100 & 97 & 95 & 100 \\
\hline \multirow{4}{*}{$\begin{array}{c}\text { Average } \\
\text { Concentrations } \\
\text { monitored in } \\
\text { stack exhaust by } \\
\text { FTIR (ppmv) }\end{array}$} & NO & 388 & 458 & 543 & 581 \\
\hline & $\mathrm{NO}_{2}$ & 77.7 & 63.9 & 88.9 & 97.3 \\
\hline & $\mathrm{CO}$ & 11.5 & 11.0 & 13.8 & 15.0 \\
\hline & $\mathrm{NH}_{3}$ & 35.2 & 58.9 & 61.5 & 65.9 \\
\hline
\end{tabular}

* - Glass production rates calculated from feed data

@ - Net time reflects the total time interval including 112 minute down time.

NM - Not Measured. 
The Catholic University of America Vitreous State Laboratory
Enhanced LAW Glass Formulation Testing Final Report, VSL-07R1130-1, Rev. 0

Table 3.4. Summary of Region C Test Conditions and Results.

\begin{tabular}{|c|c|c|c|c|c|c|}
\hline \multicolumn{7}{|c|}{ Tank Waste/Sub-Envelope Identification: AN-104/Sub-Envelope A3 } \\
\hline \multicolumn{7}{|c|}{$\mathrm{Na}_{2} \mathrm{O}$ wt.\%: Test Plan Target - 25.0, Melter Glass Target - 23.6} \\
\hline \multicolumn{7}{|c|}{ Target Minimum $\mathrm{SO}_{3}$ Concentration in Glass, wt\%: 0.65} \\
\hline \multicolumn{2}{|c|}{ Test Segment } & $4 \mathrm{~A}$ & $4 \mathrm{~B}$ & $4 \mathrm{C}$ & 4D & $4 \mathrm{E}$ \\
\hline \multirow{5}{*}{ Time } & \multirow{2}{*}{ Feed Start } & 7/3/07 & $7 / 3 / 07$ & $7 / 5 / 07$ & $7 / 6 / 07$ & $7 / 6 / 07$ \\
\hline & & 0:03 & 21:04 & 8:00 & 3:02 & $21: 26$ \\
\hline & \multirow{2}{*}{ Feed End } & 7/3/07 & $7 / 4 / 07$ & $7 / 6 / 07$ & $7 / 6 / 07$ & $7 / 7 / 07$ \\
\hline & & $14: 00$ & 3:13 & 2:00 & $17: 00$ & $2: 15$ \\
\hline & Net Slurry Feeding (hr) & 14.0 & 6.5 & 18.0@ & 14.0 & 4.9 \\
\hline \multirow{2}{*}{ Feed } & $\mathrm{wt} \% \mathrm{SO}_{3}$ as glass & 0.8 & 0 & 0.7 & 0.9 & 0 \\
\hline & Feed Used (kg) & 55.7 & 27.1 & 54.9 & 56.3 & 16.3 \\
\hline \multicolumn{2}{|c|}{ Average Production Rate $\left(\mathrm{kg} / \mathrm{m}^{2} / \mathrm{day}\right)^{*}$} & 2092 & 2192 & 1603 & 2114 & 1749 \\
\hline \multicolumn{2}{|c|}{ Average Bubbling Rate (lpm) } & 5.6 & 6.2 & 5.2 & 5.4 & 5.7 \\
\hline \multirow{5}{*}{$\begin{array}{c}\text { Average } \\
\text { Temperatures } \\
\left({ }^{\circ} \mathrm{C}\right)\end{array}$} & Glass, 2” from floor & 1147 & 1152 & 1151 & 1148 & 1153 \\
\hline & Glass, 4” from floor & 1143 & 1151 & 1148 & 1144 & 1143 \\
\hline & Electrode & 1078 & 1063 & 1055 & 1074 & 1069 \\
\hline & Plenum, thermowell & 467 & 332 & 511 & 501 & 481 \\
\hline & Plenum, exposed & 480 & 397 & 448 & 469 & 416 \\
\hline \multirow{3}{*}{ Product } & $\begin{array}{l}\text { Secondary Phases on Melt } \\
\text { Surface at Test End }\end{array}$ & Yes & No & No & Yes & No \\
\hline & Measured wt $\% \mathrm{SO}_{3}$ & 0.88 & 0.39 & 0.61 & 0.97 & 0.40 \\
\hline & $\begin{array}{c}\text { \% Feed Sulfur in Glass } \\
\text { Product }\end{array}$ & 110 & $\mathrm{NC}$ & 87 & 108 & NC \\
\hline \multirow{4}{*}{$\begin{array}{c}\text { Average } \\
\text { Concentrations } \\
\text { monitored in } \\
\text { stack exhaust by } \\
\text { FTIR (ppmv) }\end{array}$} & NO & 614 & 499 & 451 & 597 & 451 \\
\hline & $\mathrm{NO}_{2}$ & 115 & 91.8 & 76.4 & 104 & 76.2 \\
\hline & $\mathrm{CO}$ & 21.1 & 16.3 & 14.7 & 22.2 & 14.9 \\
\hline & $\mathrm{NH}_{3}$ & 51.4 & 78.4 & 47.9 & 51.3 & 50.4 \\
\hline
\end{tabular}

* - Glass production rates calculated from feed data

@ - Net time reflects the total time interval including 66 minute down time.

NC - Not Calculated. 
Table 3.5. Summary of Region D Test Conditions and Results.

\begin{tabular}{|c|c|c|c|c|c|}
\hline \multicolumn{6}{|c|}{ Tank Waste/Sub-Envelope Identification: AN-102/Sub-Envelope C2 } \\
\hline \multicolumn{6}{|c|}{$\mathrm{Na}_{2} \mathrm{O}$ wt.\%: Test Plan Target -25.0 , Melter Glass Target -21.0} \\
\hline \multicolumn{6}{|c|}{ Target Minimum $\mathrm{SO}_{3}$ Concentration in Glass, wt\%: 1.0} \\
\hline \multicolumn{2}{|c|}{ Test Segment } & $5 \mathrm{~A}$ & $5 B$ & $5 \mathrm{C}$ & $5 \mathrm{D}$ \\
\hline \multirow{3}{*}{ Time } & Feed Start & $\begin{array}{l}7 / 9 / 07 \\
19: 17\end{array}$ & $\begin{array}{c}7 / 10 / 07 \\
12: 10\end{array}$ & $\begin{array}{c}7 / 17 / 07 \\
7: 30\end{array}$ & $\begin{array}{r}7 / 17 / 07 \\
20: 50\end{array}$ \\
\hline & Feed End & $\begin{array}{c}7 / 10 / 07 \\
11: 05\end{array}$ & $\begin{array}{c}7 / 11 / 07 \\
1: 30\end{array}$ & $\begin{array}{c}7 / 17 / 07 \\
19: 50\end{array}$ & $\begin{array}{c}7 / 18 / 07 \\
9: 30\end{array}$ \\
\hline & Net Slurry Feeding (hr) & 15.8 & 13.3 & 12.3 & 12.7 \\
\hline \multirow{2}{*}{ Feed } & $\mathrm{wt} \% \mathrm{SO}_{3}$ as glass & 0.7 & 0.9 & 1.1 & 1.3 \\
\hline & Feed Used (kg) & 54.2 & 46.6 & 46.1 & 49.9 \\
\hline \multicolumn{2}{|c|}{ Average Production Rate $\left(\mathrm{kg} / \mathrm{m}^{2} / \text { day }\right)^{*}$} & 2039 & 2082 & 2227 & 2335 \\
\hline \multicolumn{2}{|c|}{ Average Bubbling Rate (lpm) } & 5.0 & 5.7 & 3.7 & 4.3 \\
\hline \multirow{5}{*}{$\begin{array}{c}\text { Average } \\
\text { Temperatures } \\
\left({ }^{\circ} \mathrm{C}\right)\end{array}$} & Glass, 2" from floor & 1144 & 1152 & 1152 & 1152 \\
\hline & Glass, 4” from floor & 1146 & 1150 & 1147 & 1148 \\
\hline & Electrode & 1067 & 1076 & 1095 & 1085 \\
\hline & Plenum, thermowell & 559 & 553 & 574 & 552 \\
\hline & Plenum, exposed & 543 & 517 & 567 & 545 \\
\hline \multirow{3}{*}{ Product } & $\begin{array}{l}\text { Secondary Phases on Melt } \\
\text { Surface at Test End }\end{array}$ & No & No & No & Yes \\
\hline & Measured wt $\% \mathrm{SO}_{3}$ & 0.69 & 0.77 & 0.89 & 1.25 \\
\hline & $\begin{array}{c}\text { \% Feed Sulfur in Glass } \\
\text { Product }\end{array}$ & 99 & 86 & 81 & 96 \\
\hline \multirow{4}{*}{$\begin{array}{c}\text { Average } \\
\text { Concentrations } \\
\text { monitored in } \\
\text { stack exhaust by } \\
\text { FTIR (ppmv) }\end{array}$} & NO & 609 & 619 & 539 & 574 \\
\hline & $\mathrm{NO}_{2}$ & 130 & 127 & 118 & 133 \\
\hline & $\mathrm{CO}$ & 27.4 & 34.5 & 30.6 & 35.7 \\
\hline & $\mathrm{NH}_{3}$ & 24.8 & 25.8 & 11.3 & 17.9 \\
\hline
\end{tabular}

* - Glass production rates calculated from feed data NM - Not Measured. 
Table 4.1. Listing of DM10 Glasses Discharged, Masses, Target Sulfur Contents and Analysis Performed.

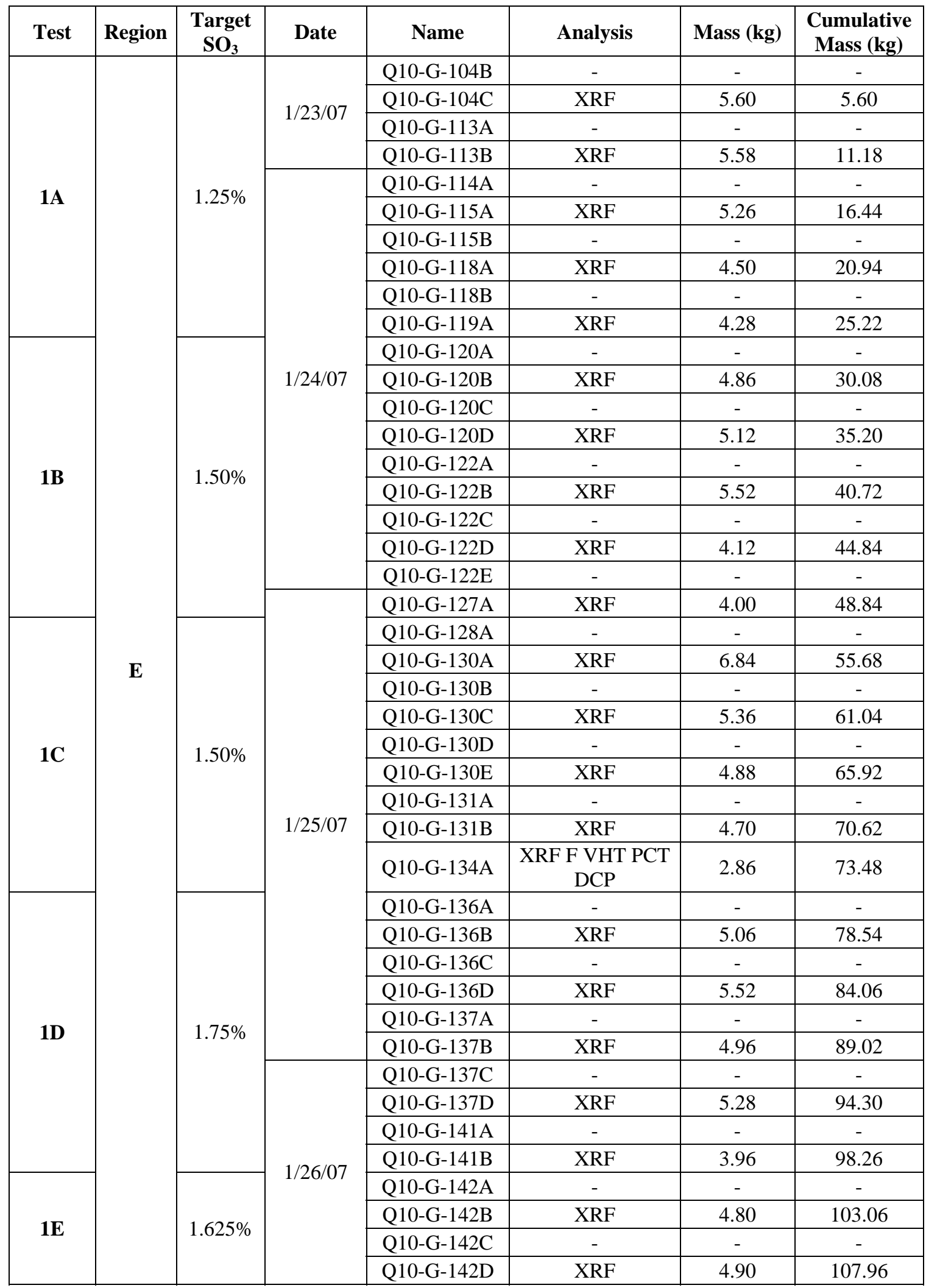

"-" Empty data field 
Table 4.1. Listing of DM10 Glasses Discharged, Masses, Target Sulfur Contents and Analysis Performed (continued).

\begin{tabular}{|c|c|c|c|c|c|c|c|}
\hline Test & Region & $\begin{array}{c}\text { Target } \\
\mathrm{SO}_{3}\end{array}$ & Date & Name & Analysis & Mass (kg) & $\begin{array}{c}\text { Cumulative } \\
\text { Mass (kg) }\end{array}$ \\
\hline \multirow{6}{*}{$1 E$} & \multirow{6}{*}{$\mathbf{E}$} & \multirow{6}{*}{$1.625 \%$} & \multirow{6}{*}{$1 / 26 / 07$} & Q10-G-142E & - & - & - \\
\hline & & & & Q10-G-142F & XRF & 4.90 & 112.86 \\
\hline & & & & Q10-G-147A & - & - & - \\
\hline & & & & Q10-G-147B & XRF & 4.74 & 117.60 \\
\hline & & & & Q10-G-147C & - & - & - \\
\hline & & & & Q10-G-148A & XRF & 4.84 & 122.44 \\
\hline \multirow{15}{*}{$2 A$} & \multirow{36}{*}{ A } & \multirow{15}{*}{$0.10 \%$} & \multirow{15}{*}{ 6/6/07 } & R10-G-89A & - & - & - \\
\hline & & & & R10-G-89B & XRF & 3.24 & 125.68 \\
\hline & & & & R10-G-89C & - & - & - \\
\hline & & & & R10-G-89D & XRF & 2.82 & 128.5 \\
\hline & & & & R10-G-90A & - & - & - \\
\hline & & & & R10-G-90B & XRF & 3.74 & 132.24 \\
\hline & & & & R10-G-90C & - & - & - \\
\hline & & & & R10-G-90D & - & - & - \\
\hline & & & & R10-G-90E & XRF & 4.68 & 136.92 \\
\hline & & & & R10-G-91A & - & - & - \\
\hline & & & & R10-G-91B & XRF & 4.18 & 141.10 \\
\hline & & & & R10-G-91C & - & - & - \\
\hline & & & & R10-G-91D & - & - & - \\
\hline & & & & R10-G-91E & XRF & 5.08 & 146.18 \\
\hline & & & & R10-G-95A & - & - & - \\
\hline \multirow{11}{*}{$2 B$} & & \multirow{11}{*}{$0.20 \%$} & \multirow{20}{*}{ 6/7/07 } & R10-G-96A & XRF & 3.20 & 149.38 \\
\hline & & & & R10-G-96B & - & - & - \\
\hline & & & & R10-G-98A & XRF & 4.12 & 153.50 \\
\hline & & & & R10-G-98B & - & - & - \\
\hline & & & & R10-G-99A & XRF & 4.58 & 158.08 \\
\hline & & & & R10-G-99B & - & - & - \\
\hline & & & & R10-G-99C & XRF & 3.20 & 161.28 \\
\hline & & & & R10-G-100A & - & - & - \\
\hline & & & & R10-G-100B & XRF & 4.08 & 165.36 \\
\hline & & & & R10-G-101A & - & - & - \\
\hline & & & & R10-G-101B & XRF & 3.64 & 169.00 \\
\hline \multirow{10}{*}{$2 \mathrm{C}$} & & \multirow{10}{*}{$0.30 \%$} & & R10-G-104A & - & - & - \\
\hline & & & & R10-G-104B & $\mathrm{XRF}$ & 4.74 & 173.74 \\
\hline & & & & R10-G-105A & - & - & - \\
\hline & & & & R10-G-105B & XRF & 3.32 & 177.06 \\
\hline & & & & R10-G-105C & - & - & - \\
\hline & & & & R10-G-105D & XRF & 3.02 & 180.08 \\
\hline & & & & R10-G-105E & - & - & - \\
\hline & & & & R10-G-107A & XRF & 3.58 & 183.66 \\
\hline & & & & R10-G-107B & - & - & - \\
\hline & & & $6 / 8 / 07$ & R10-G-107C & XRF & 3.02 & 186.68 \\
\hline
\end{tabular}

"-" Empty data field 
Table 4.1. Listing of DM10 Glasses Discharged, Masses, Target Sulfur Contents and Analysis Performed (continued).

\begin{tabular}{|c|c|c|c|c|c|c|c|}
\hline Test & Region & $\begin{array}{c}\text { Target } \\
\mathrm{SO}_{3} \\
\end{array}$ & Date & Name & Analysis & Mass (kg) & $\begin{array}{c}\text { Cumulative } \\
\text { Mass (kg) }\end{array}$ \\
\hline \multirow{2}{*}{$2 \mathrm{C}$} & \multirow{43}{*}{ A } & \multirow{2}{*}{$0.30 \%$} & \multirow{13}{*}{ 6/8/07 } & R10-G-111A & XRF & 3.80 & 190.48 \\
\hline & & & & R10-G-112A & $\mathrm{XRF}$ & 3.26 & 193.74 \\
\hline \multirow{11}{*}{$2 D$} & & \multirow{11}{*}{$0.40 \%$} & & R10-G-112B & - & - & - \\
\hline & & & & R10-G-112C & XRF & 3.76 & 197.50 \\
\hline & & & & R10-G-112D & - & - & - \\
\hline & & & & R10-G-114A & XRF & 3.98 & 201.48 \\
\hline & & & & R10-G-118A & - & - & - \\
\hline & & & & R10-G-119A & XRF & 4.04 & 205.52 \\
\hline & & & & R10-G-119B & - & - & - \\
\hline & & & & R10-G-119C & XRF & 3.76 & 209.28 \\
\hline & & & & R10-G-119D & - & - & - \\
\hline & & & & R10-G-119E & - & - & - \\
\hline & & & & R10-G-119F & $\mathrm{XRF}$ & 4.60 & 213.88 \\
\hline \multirow{10}{*}{$2 \mathbf{E}$} & & \multirow{10}{*}{$0.50 \%$} & \multirow{3}{*}{ 6/11/07 } & R10-G-129A & - & - & - \\
\hline & & & & R10-G-129B & XRF & 3.24 & 217.12 \\
\hline & & & & R10-G-129C & XRF & 3.32 & 220.44 \\
\hline & & & \multirow{7}{*}{ 6/12/07 } & R10-G-134A & - & - & - \\
\hline & & & & R10-G-134B & XRF & 3.02 & 223.46 \\
\hline & & & & R10-G-134C & - & - & - \\
\hline & & & & R10-G-134D & XRF & 3.56 & 227.02 \\
\hline & & & & R10-G-134E & - & - & - \\
\hline & & & & R10-G-135A & XRF & 3.62 & 230.64 \\
\hline & & & & R10-G-135B & $\mathrm{XRF}$ & 4.18 & 234.82 \\
\hline \multirow{9}{*}{$2 \mathbf{F}$} & & \multirow{9}{*}{$0.60 \%$} & \multirow{6}{*}{$6 / 14 / 07$} & R10-G-148A & XRF & 4.02 & 238.84 \\
\hline & & & & R10-G-148B & XRF & 3.56 & 242.40 \\
\hline & & & & R10-G-149A & XRF & 2.62 & 245.02 \\
\hline & & & & R10-G-150A & - & - & - \\
\hline & & & & R10-G-153A & $\mathrm{XRF}$ & 3.56 & 248.58 \\
\hline & & & & R10-G-153B & - & - & - \\
\hline & & & \multirow{3}{*}{ 6/15/07 } & R10-G-153C & XRF & 3.92 & 252.50 \\
\hline & & & & R10-G-155A & $\begin{array}{c}\text { XRF F VHT PCT } \\
\text { DCP }\end{array}$ & 2.88 & 255.38 \\
\hline & & & & R10-G-155B & XRF & 1.64 & 257.02 \\
\hline \multirow{9}{*}{$\mathbf{3 A}$} & & \multirow{9}{*}{$0.60 \%$} & \multirow{9}{*}{$6 / 15 / 07$} & S10-G-14A & - & - & - \\
\hline & & & & S10-G-14B & XRF & 2.42 & 259.44 \\
\hline & & & & R10-G-14C & - & - & - \\
\hline & & & & S10-G-15A & XRF & 5.94 & 265.38 \\
\hline & & & & S10-G-15B & - & - & - \\
\hline & & & & S10-G-15C & XRF & 5.62 & 271.00 \\
\hline & & & & S10-G-16A & - & - & - \\
\hline & & & & S10-G-16B & $\mathrm{XRF}$ & 4.26 & 275.26 \\
\hline & & & & S10-G-22A & XRF & 3.70 & 278.96 \\
\hline \multirow{2}{*}{ 3B } & & \multirow{2}{*}{$0.70 \%$} & $6 / 28 / 07$ & S10-G-30A & XRF & 3.98 & 282.94 \\
\hline & & & $6 / 29 / 07$ & S10-G-31A & XRF & 4.60 & 287.54 \\
\hline
\end{tabular}

"-" Empty data field 
Table 4.1. Listing of DM10 Glasses Discharged, Masses, Target Sulfur Contents and Analysis Performed (continued).

\begin{tabular}{|c|c|c|c|c|c|c|c|}
\hline Test & Region & $\begin{array}{c}\text { Target } \\
\mathrm{SO}_{3}\end{array}$ & Date & Name & Analysis & Mass (kg) & $\begin{array}{c}\text { Cumulative } \\
\text { Mass (kg) }\end{array}$ \\
\hline \multirow{6}{*}{ 3B } & \multirow{30}{*}{ B } & \multirow{6}{*}{$0.70 \%$} & \multirow{13}{*}{ 6/29/07 } & S10-G-32A & XRF & 4.74 & 292.28 \\
\hline & & & & S10-G-33A & - & - & - \\
\hline & & & & S10-G-33B & XRF & 3.52 & 295.80 \\
\hline & & & & S10-G-36A & - & - & - \\
\hline & & & & S10-G-36B & XRF & 3.54 & 299.34 \\
\hline & & & & S10-G-36C & $\mathrm{XRF}$ & 1.86 & 301.20 \\
\hline \multirow{13}{*}{$3 C$} & & \multirow{13}{*}{$0.85 \%$} & & S10-G-37A & - & - & - \\
\hline & & & & S10-G-37B & XRF & 2.06 & 303.26 \\
\hline & & & & S10-G-39A & - & - & - \\
\hline & & & & S10-G-39B & XRF & 4.24 & 307.50 \\
\hline & & & & S10-G-42A & - & - & - \\
\hline & & & & S10-G-42B & XRF & 3.86 & 311.36 \\
\hline & & & & S10-G-42C & - & - & - \\
\hline & & & \multirow{6}{*}{ 6/30/07 } & S10-G-42D & $\mathrm{XRF}$ & 4.42 & 315.78 \\
\hline & & & & S10-G-44A & - & - & - \\
\hline & & & & S10-G-44B & XRF & 3.98 & 319.76 \\
\hline & & & & S10-G-44C & - & - & - \\
\hline & & & & S10-G-44D & - & - & - \\
\hline & & & & S10-G-45A & $\begin{array}{c}\text { XRF F VHT PCT } \\
\text { DCP } \\
\end{array}$ & 5.70 & 325.46 \\
\hline \multirow{11}{*}{ 3D } & & \multirow{11}{*}{$1.00 \%$} & \multirow{11}{*}{ 7/2/07 } & S10-G-53A & - & - & - \\
\hline & & & & S10-G-53B & $\mathrm{XRF}$ & 3.76 & 329.22 \\
\hline & & & & S10-G-57A & - & - & - \\
\hline & & & & S10-G-57B & XRF & 4.44 & 333.66 \\
\hline & & & & S10-G-57C & - & - & - \\
\hline & & & & S10-G-57D & XRF & 3.70 & 337.36 \\
\hline & & & & S10-G-58A & - & - & - \\
\hline & & & & S10-G-58B & $\mathrm{XRF}$ & 4.26 & 341.62 \\
\hline & & & & S10-G-58C & - & - & - \\
\hline & & & & S10-G-59A & $\mathrm{XRF}$ & 3.88 & 345.50 \\
\hline & & & & S10-G-59B & XRF F & 2.32 & 347.82 \\
\hline \multirow{12}{*}{$4 \mathrm{~A}$} & \multirow{12}{*}{ C } & \multirow{12}{*}{$0.80 \%$} & \multirow{12}{*}{ 7/3/07 } & S10-G-70A & XRF & 3.88 & 351.70 \\
\hline & & & & S10-G-71A & - & - & - \\
\hline & & & & S10-G-72A & $\mathrm{XRF}$ & 3.12 & 354.82 \\
\hline & & & & S10-G-72B & - & - & - \\
\hline & & & & S10-G-73A & $\mathrm{XRF}$ & 3.62 & 358.44 \\
\hline & & & & S10-G-73B & - & - & - \\
\hline & & & & S10-G-73C & XRF & 2.98 & 361.42 \\
\hline & & & & S10-G-73D & - & - & - \\
\hline & & & & S10-G-73E & XRF & 4.42 & 365.84 \\
\hline & & & & S10-G-76A & - & - & - \\
\hline & & & & S10-G-76B & XRF & 4.44 & 370.28 \\
\hline & & & & S10-G-76C & XRF & 1.74 & 372.02 \\
\hline
\end{tabular}

"-" Empty data field 
Table 4.1. Listing of DM10 Glasses Discharged, Masses, Target Sulfur Contents and Analysis Performed (continued).

\begin{tabular}{|c|c|c|c|c|c|c|c|}
\hline Test & Region & $\begin{array}{c}\text { Target } \\
\mathrm{SO}_{3}\end{array}$ & Date & Name & Analysis & Mass (kg) & $\begin{array}{c}\text { Cumulative } \\
\text { Mass (kg) }\end{array}$ \\
\hline \multirow{4}{*}{$4 B$} & \multirow{30}{*}{ C } & \multirow{4}{*}{$0.00 \%$} & 7/3/07 & S10-G-81A & - & - & - \\
\hline & & & \multirow{3}{*}{ 7/4/07 } & S10-G-81B & - & - & - \\
\hline & & & & S10-G-82A & XRF & 3.56 & 375.58 \\
\hline & & & & S10-G-83A & XRF & 2.90 & 378.48 \\
\hline \multirow{10}{*}{$4 \mathrm{C}$} & & \multirow{10}{*}{$0.70 \%$} & \multirow{8}{*}{ 7/5/07 } & S10-G-94A & XRF & 4.06 & 382.54 \\
\hline & & & & S10-G-94B & XRF & 3.04 & 385.58 \\
\hline & & & & S10-G-95A & - & - & - \\
\hline & & & & S10-G-95B & XRF & 3.56 & 389.14 \\
\hline & & & & S10-G-95C & - & - & - \\
\hline & & & & S10-G-96A & XRF & 4.00 & 393.14 \\
\hline & & & & S10-G-97A & XRF & 3.00 & 396.14 \\
\hline & & & & S10-G-97B & - & - & - \\
\hline & & & \multirow{14}{*}{ 7/6/07 } & S10-G-101A & XRF & 4.20 & 400.34 \\
\hline & & & & S10-G-101B & $\begin{array}{c}\text { XRF F VHT PCT } \\
\text { DCP }\end{array}$ & 3.22 & 403.56 \\
\hline \multirow{12}{*}{ 4D } & & \multirow{12}{*}{$0.90 \%$} & & S10-G-102A & - & - & - \\
\hline & & & & S10-G-103A & XRF & 3.92 & 407.48 \\
\hline & & & & S10-G-103B & - & - & - \\
\hline & & & & S10-G-103C & XRF & 3.34 & 410.82 \\
\hline & & & & S10-G-106A & - & - & - \\
\hline & & & & S10-G-106B & XRF & 3.04 & 413.86 \\
\hline & & & & S10-G-106C & - & - & - \\
\hline & & & & S10-G-106D & XRF & 3.34 & 417.20 \\
\hline & & & & S10-G-106E & - & - & - \\
\hline & & & & S10-G-109A & XRF & 4.20 & 421.40 \\
\hline & & & & S10-G-109B & XRF & 4.22 & 425.62 \\
\hline & & & & S10-G-111A & XRF & 1.28 & 426.90 \\
\hline \multirow{4}{*}{$4 E$} & & \multirow{4}{*}{$0.00 \%$} & \multirow{4}{*}{ 7/7/07 } & S10-G-113A & - & - & - \\
\hline & & & & S10-G-113B & XRF & 2.86 & 429.76 \\
\hline & & & & S10-G-116A & - & - & - \\
\hline & & & & S10-G-117A & XRF & 2.56 & 432.32 \\
\hline \multirow{11}{*}{$5 A$} & \multirow{13}{*}{ D } & \multirow{11}{*}{$0.70 \%$} & \multirow{3}{*}{ 7/9/07 } & S10-G-132A & XRF & 3.56 & 435.88 \\
\hline & & & & S10-G-132B & XRF & 3.28 & 439.16 \\
\hline & & & & S10-G-133A & - & - & - \\
\hline & & & \multirow{10}{*}{ 7/10/07 } & S10-G-134A & XRF & 4.32 & 443.48 \\
\hline & & & & S10-G-135A & - & - & - \\
\hline & & & & S10-G-135B & XRF & 3.48 & 446.96 \\
\hline & & & & S10-G-136A & - & - & - \\
\hline & & & & S10-G-136B & XRF & 5.16 & 452.12 \\
\hline & & & & S10-G-136C & - & - & - \\
\hline & & & & S10-G-136D & XRF & 3.76 & 455.88 \\
\hline & & & & S10-G-139A & XRF & 2.96 & 458.84 \\
\hline \multirow{2}{*}{$5 B$} & & \multirow{2}{*}{$0.90 \%$} & & S10-G-141A & - & - & - \\
\hline & & & & S10-G-141B & XRF & 5.02 & 463.86 \\
\hline
\end{tabular}

\footnotetext{
"-" Empty data field
} 
Table 4.1. Listing of DM10 Glasses Discharged, Masses, Target Sulfur Contents and Analysis Performed (continued).

\begin{tabular}{|c|c|c|c|c|c|c|c|}
\hline Test & Region & $\begin{array}{c}\text { Target } \\
\mathrm{SO}_{3} \\
\end{array}$ & Date & Name & Analysis & Mass (kg) & $\begin{array}{c}\text { Cumulative } \\
\text { Mass (kg) }\end{array}$ \\
\hline \multirow{10}{*}{$5 B$} & \multirow{29}{*}{ D } & \multirow{10}{*}{$0.90 \%$} & \multirow{7}{*}{$7 / 10 / 07$} & S10-G-141C & - & - & - \\
\hline & & & & S10-G-144A & XRF & 3.80 & 467.66 \\
\hline & & & & S10-G-144B & - & - & - \\
\hline & & & & S10-G-144C & XRF & 3.04 & 470.70 \\
\hline & & & & S10-G-144D & - & - & - \\
\hline & & & & S10-G-145A & XRF & 3.22 & 473.92 \\
\hline & & & & S10-G-145B & - & - & - \\
\hline & & & \multirow{3}{*}{$7 / 11 / 07$} & S10-G-145C & XRF & 4.52 & 478.44 \\
\hline & & & & S10-G-145D & - & - & - \\
\hline & & & & S10-G-148A & XRF & 2.50 & 480.94 \\
\hline \multirow{8}{*}{$5 C$} & & \multirow{8}{*}{$1.10 \%$} & \multirow{10}{*}{ 7/17/07 } & T10-G-12A & - & - & - \\
\hline & & & & T10-G-13A & XRF & 6.68 & 487.62 \\
\hline & & & & T10-G-13B & - & - & - \\
\hline & & & & T10-G-13C & XRF & 5.48 & 493.10 \\
\hline & & & & T10-G-13D & - & - & - \\
\hline & & & & T10-G-13E & XRF & 4.54 & 497.64 \\
\hline & & & & T10-G-13F & - & - & - \\
\hline & & & & T10-G-16A & $\begin{array}{c}\text { XRF F VHT PCT } \\
\text { DCP }\end{array}$ & 4.92 & 502.56 \\
\hline \multirow{11}{*}{ 5D } & & \multirow{11}{*}{$1.30 \%$} & & T10-G-16B & - & - & - \\
\hline & & & & T10-G-18A & XRF & 4.84 & 507.40 \\
\hline & & & \multirow{9}{*}{ 7/18/07 } & T10-G-18B & - & - & - \\
\hline & & & & T10-G-18C & XRF & 5.16 & 512.56 \\
\hline & & & & T10-G-18D & - & - & - \\
\hline & & & & T10-G-19A & XRF & 3.92 & 516.48 \\
\hline & & & & T10-G-19B & - & - & - \\
\hline & & & & T10-G-19C & XRF & 4.68 & 521.16 \\
\hline & & & & T10-G-23A & - & - & - \\
\hline & & & & T10-G-23B & XRF & 4.24 & 525.40 \\
\hline & & & & T10-G-23C & XRF & 1.86 & 527.26 \\
\hline
\end{tabular}

"-" Empty data field 
Table 4.2. XRF Analyzed Compositions for DM10 Discharged Glass Samples (wt\%).

\begin{tabular}{|c|c|c|c|c|c|c|c|c|c|c|c|}
\hline Test & \multicolumn{5}{|c|}{$1 \mathrm{~A}$} & \multicolumn{5}{|c|}{ 1B } & $1 \mathrm{C}$ \\
\hline Region & \multicolumn{11}{|c|}{$\mathbf{E}$} \\
\hline Target $\mathrm{SO}_{3}$ & \multicolumn{5}{|c|}{1.25} & \multicolumn{5}{|c|}{1.50} & 1.50 \\
\hline Glass (kg) & 5.60 & 11.18 & 16.44 & 20.94 & 25.22 & 30.08 & 35.20 & 40.72 & 44.84 & 48.84 & 55.68 \\
\hline Conctitunt & Q10-G- & Q10-G- & Q10-G- & Q10-G & Q10-G & Q10-G- & Q10-G & Q10-G- & Q10-G- & Q10-G & Q10-G \\
\hline Constituent & 104C & 113B & $115 \mathrm{~A}$ & $118 \mathrm{~A}$ & 119A & $120 \mathrm{~B}$ & $120 \mathrm{D}$ & $122 \mathrm{~B}$ & 122D & $127 \mathrm{~A}$ & $130 \mathrm{~A}$ \\
\hline $\mathrm{Al}_{2} \mathrm{O}_{3}$ & 6.31 & 6.65 & 7.10 & 7.25 & 7.15 & 7.52 & 7.50 & 7.49 & 7.34 & 7.27 & 7.34 \\
\hline $\mathrm{As}_{2} \mathrm{O}_{5}$ & $<0.01$ & $<0.01$ & $<0.01$ & $<0.01$ & $<0.01$ & $<0.01$ & $<0.01$ & $<0.01$ & $<0.01$ & $<0.01$ & $<0.01$ \\
\hline $\mathrm{B}_{2} \mathrm{O}_{3} *$ & 9.72 & 9.78 & 9.81 & 9.82 & 9.83 & 9.83 & 9.83 & 9.82 & 9.82 & 9.82 & 9.82 \\
\hline $\mathrm{CaO}$ & 4.49 & 6.68 & 8.03 & 8.63 & 9.02 & 9.39 & 9.64 & 9.97 & 10.06 & 10.63 & 10.21 \\
\hline $\mathrm{Cl}$ & 0.23 & 0.13 & 0.07 & 0.07 & 0.06 & 0.05 & 0.04 & 0.04 & 0.04 & 0.03 & 0.03 \\
\hline $\mathrm{Cr}_{2} \mathrm{O}_{3}$ & 0.88 & 0.86 & 0.83 & 0.81 & 0.80 & 0.80 & 0.76 & 0.76 & 0.76 & 0.80 & 0.64 \\
\hline $\mathrm{Cs}_{2} \mathrm{O}$ & 0.05 & 0.10 & 0.11 & 0.13 & 0.14 & 0.17 & 0.17 & 0.17 & 0.17 & 0.17 & 0.19 \\
\hline $\mathrm{F}^{*}$ & 0.19 & 0.19 & 0.20 & 0.20 & 0.20 & 0.20 & 0.20 & 0.20 & 0.20 & 0.20 & 0.20 \\
\hline $\mathrm{Fe}_{2} \mathrm{O}_{3}$ & 4.99 & 3.32 & 2.10 & 1.64 & 1.34 & 0.94 & 0.77 & 0.64 & 0.55 & 0.51 & 0.54 \\
\hline $\mathrm{I}$ & $<0.01$ & $<0.01$ & $<0.01$ & $<0.01$ & $<0.01$ & $<0.01$ & $<0.01$ & $<0.01$ & $<0.01$ & $<0.01$ & $<0.01$ \\
\hline $\mathrm{K}_{2} \mathrm{O}$ & 3.71 & 2.64 & 1.81 & 1.52 & 1.33 & 1.06 & 0.90 & 0.83 & 0.79 & 0.77 & 0.68 \\
\hline $\mathrm{La}_{2} \mathrm{O}_{3}$ & $<0.01$ & $<0.01$ & $<0.01$ & $<0.01$ & $<0.01$ & $<0.01$ & $<0.01$ & $<0.01$ & $<0.01$ & $<0.01$ & $<0.01$ \\
\hline $\mathrm{Li}_{2} \mathrm{O}^{*}$ & 1.07 & 1.68 & 2.02 & 2.19 & 2.30 & 2.37 & 2.42 & 2.45 & 2.47 & 2.48 & 2.48 \\
\hline $\mathrm{MgO}$ & 1.24 & 1.06 & 1.04 & 1.01 & 0.92 & 0.92 & 0.98 & 0.96 & 0.98 & 0.83 & 0.91 \\
\hline $\mathrm{MnO}$ & 0.01 & 0.01 & 0.01 & 0.02 & 0.01 & 0.01 & 0.01 & 0.01 & 0.01 & 0.01 & 0.01 \\
\hline $\mathrm{Na}_{2} \mathrm{O}$ & 17.31 & 16.30 & 16.06 & 15.82 & 16.38 & 15.78 & 15.88 & 14.90 & 15.62 & 14.48 & 15.61 \\
\hline $\mathrm{Nd}_{2} \mathrm{O}_{3}$ & $<0.01$ & $<0.01$ & $<0.01$ & $<0.01$ & $<0.01$ & $<0.01$ & $<0.01$ & $<0.01$ & $<0.01$ & $<0.01$ & $<0.01$ \\
\hline $\mathrm{NiO}$ & 0.03 & 0.03 & 0.02 & 0.02 & 0.02 & 0.02 & 0.02 & 0.02 & 0.02 & 0.02 & 0.02 \\
\hline $\mathrm{P}_{2} \mathrm{O}_{5}$ & 2.38 & 1.54 & 1.00 & 0.77 & 0.64 & 0.47 & 0.35 & 0.28 & 0.27 & 0.22 & 0.20 \\
\hline $\mathrm{PbO}$ & 0.01 & $<0.01$ & $<0.01$ & 0.01 & $<0.01$ & $<0.01$ & $<0.01$ & $<0.01$ & $<0.01$ & $<0.01$ & $<0.01$ \\
\hline $\mathrm{Sb}_{2} \mathrm{O}_{3}$ & $<0.01$ & $<0.01$ & $<0.01$ & $<0.01$ & $<0.01$ & $<0.01$ & $<0.01$ & $<0.01$ & $<0.01$ & $<0.01$ & $<0.01$ \\
\hline $\mathrm{SeO}_{2}$ & $<0.01$ & $<0.01$ & $<0.01$ & $<0.01$ & $<0.01$ & $<0.01$ & $<0.01$ & $<0.01$ & $<0.01$ & $<0.01$ & $<0.01$ \\
\hline $\mathrm{SiO}_{2}$ & 39.23 & 40.01 & 40.73 & 40.78 & 40.69 & 41.07 & 41.00 & 41.50 & 40.82 & 41.15 & 40.99 \\
\hline $\mathrm{SnO}_{2}$ & $<0.01$ & $<0.01$ & $<0.01$ & $<0.01$ & $<0.01$ & $<0.01$ & $<0.01$ & $<0.01$ & $<0.01$ & $<0.01$ & $<0.01$ \\
\hline $\mathrm{SO}_{3}$ & 0.63 & 0.83 & 0.92 & 1.01 & 1.06 & 1.17 & 1.26 & 1.33 & 1.33 & 1.40 & 1.33 \\
\hline $\mathrm{SrO}$ & $<0.01$ & $<0.01$ & $<0.01$ & $<0.01$ & $<0.01$ & $<0.01$ & $<0.01$ & $<0.01$ & $<0.01$ & $<0.01$ & $<0.01$ \\
\hline $\mathrm{TiO}_{2}$ & 1.05 & 0.73 & 0.50 & 0.41 & 0.35 & 0.27 & 0.23 & 0.21 & 0.20 & 0.20 & 0.18 \\
\hline $\mathrm{V}_{2} \mathrm{O}_{5}$ & 0.59 & 1.13 & 1.46 & 1.61 & 1.72 & 1.81 & 1.87 & 1.93 & 1.96 & 2.13 & 2.01 \\
\hline $\mathrm{ZnO}$ & 3.15 & 3.30 & 3.22 & 3.23 & 3.19 & 3.18 & 3.14 & 3.22 & 3.28 & 3.50 & 3.30 \\
\hline $\mathrm{ZrO}_{2}$ & 2.74 & 3.02 & 2.97 & 3.02 & 2.84 & 2.96 & 3.04 & 3.27 & 3.31 & 3.36 & 3.30 \\
\hline Sum & 100.00 & 100.00 & 100.00 & 100.00 & 100.00 & 100.00 & 100.00 & 100.00 & 100.00 & 100.00 & 100.00 \\
\hline
\end{tabular}

* - Target values calculated based on simple well-stirred tank model

$\S$ - Not a target constituent 
Table 4.2. XRF Analyzed Compositions for DM10 Discharged Glass Samples (wt\%) (continued).

\begin{tabular}{|c|c|c|c|c|c|c|c|c|c|c|c|}
\hline Test & \multicolumn{4}{|c|}{ 1C } & \multicolumn{5}{|c|}{ 1D } & \multicolumn{2}{|c|}{ 1E } \\
\hline Region & \multicolumn{11}{|c|}{$\mathbf{E}$} \\
\hline Target $\mathrm{SO}_{3}$ & \multicolumn{4}{|c|}{1.50} & \multicolumn{5}{|c|}{1.75} & \multicolumn{2}{|c|}{1.625} \\
\hline Glass (kg) & 61.04 & 65.92 & 70.62 & 73.48 & 78.54 & 84.06 & 89.02 & 94.30 & 98.26 & 103.06 & 107.96 \\
\hline & Q10-G- & Q10-G- & Q10-G & Q10-G & Q10-G & Q10-G & Q10-G- & Q10-G & Q10-G- & Q10-G- & Q10-G \\
\hline Constituent & 130C & $130 \mathrm{E}$ & $131 \mathrm{~B}$ & $134 \mathrm{~A}$ & $136 \mathrm{~B}$ & $136 \mathrm{D}$ & 137B & 137D & 141B & $142 \mathrm{~B}$ & $142 \mathrm{D}$ \\
\hline $\mathrm{Al}_{2} \mathrm{O}_{3}$ & 7.23 & 7.28 & 7.57 & 7.58 & 7.39 & 7.21 & 7.16 & 7.32 & 7.25 & 7.45 & 7.30 \\
\hline $\mathrm{As}_{2} \mathrm{O}_{5}$ & $<0.01$ & $<0.01$ & $<0.01$ & $<0.01$ & $<0.01$ & $<0.01$ & $<0.01$ & $<0.01$ & $<0.01$ & $<0.01$ & $<0.01$ \\
\hline $\mathrm{B}_{2} \mathrm{O}_{3} *$ & 9.82 & 9.82 & 9.82 & 9.82 & 9.81 & 9.80 & 9.80 & 9.80 & 9.80 & 9.80 & 9.80 \\
\hline $\mathrm{CaO}$ & \begin{tabular}{|l|}
10.24 \\
\end{tabular} & 10.15 & \begin{tabular}{|l|}
10.01 \\
\end{tabular} & 10.16 & 10.39 & 10.18 & 10.19 & 10.25 & 10.44 & 9.95 & 10.19 \\
\hline $\mathrm{Cl}$ & 0.03 & 0.03 & 0.03 & 0.03 & 0.03 & 0.03 & 0.02 & 0.02 & 0.02 & 0.03 & 0.03 \\
\hline $\mathrm{Cr}_{2} \mathrm{O}_{3}$ & 0.57 & 0.52 & 0.49 & 0.48 & 0.48 & 0.45 & 0.45 & 0.44 & 0.44 & 0.42 & 0.44 \\
\hline $\mathrm{Cs}_{2} \mathrm{O}$ & 0.18 & 0.17 & 0.16 & 0.16 & 0.19 & 0.19 & 0.20 & 0.19 & 0.15 & 0.18 & 0.21 \\
\hline $\mathrm{F}^{*}$ & 0.20 & 0.20 & 0.20 & 0.20 & 0.20 & 0.20 & 0.20 & 0.20 & 0.20 & 0.20 & 0.20 \\
\hline $\mathrm{Fe}_{2} \mathrm{O}_{3}$ & 0.45 & 0.41 & 0.42 & 0.43 & 0.38 & 0.37 & 0.37 & 0.36 & 0.37 & 0.39 & 0.38 \\
\hline $\mathrm{I}$ & $<0.01$ & $<0.01$ & $<0.01$ & $<0.01$ & $<0.01$ & $<0.01$ & $<0.01$ & $<0.01$ & $<0.01$ & $<0.01$ & $<0.01$ \\
\hline $\mathrm{K}_{2} \mathrm{O}$ & 0.67 & 0.64 & 0.64 & 0.63 & 0.63 & 0.60 & 0.60 & 0.60 & 0.62 & 0.62 & 0.63 \\
\hline $\mathrm{La}_{2} \mathrm{O}_{3}$ & $<0.01$ & $<0.01$ & $<0.01$ & $<0.01$ & $<0.01$ & $<0.01$ & $<0.01$ & $<0.01$ & $<0.01$ & $<0.01$ & $<0.01$ \\
\hline $\mathrm{Li}_{2} \mathrm{O}^{*}$ & 2.49 & 2.49 & 2.49 & 2.49 & 2.49 & 2.49 & 2.49 & 2.49 & 2.49 & 2.49 & 2.49 \\
\hline $\mathrm{MgO}$ & 0.94 & 1.01 & 0.98 & 0.95 & 0.92 & 1.03 & 0.98 & 0.96 & 0.77 & 0.78 & 0.98 \\
\hline $\mathrm{MnO}$ & 0.01 & 0.01 & 0.02 & 0.01 & 0.01 & 0.01 & 0.01 & 0.01 & 0.01 & 0.03 & 0.02 \\
\hline $\mathrm{Na}_{2} \mathrm{O}$ & 15.69 & 15.94 & 15.46 & 15.45 & 15.08 & 16.02 & 16.11 & 15.58 & 15.40 & 16.23 & 15.35 \\
\hline $\mathrm{Nd}_{2} \mathrm{O}_{3}$ & $<0.01$ & $<0.01$ & $<0.01$ & $<0.01$ & $<0.01$ & $<0.01$ & $<0.01$ & $<0.01$ & $<0.01$ & $<0.01$ & $<0.01$ \\
\hline $\mathrm{NiO}$ & 0.02 & 0.02 & 0.02 & 0.02 & 0.02 & 0.02 & 0.02 & 0.02 & 0.02 & 0.02 & 0.02 \\
\hline $\mathrm{P}_{2} \mathrm{O}_{5}$ & 0.22 & 0.19 & 0.21 & 0.19 & 0.19 & 0.18 & 0.18 & 0.18 & 0.18 & 0.18 & 0.18 \\
\hline $\mathrm{PbO}$ & $<0.01$ & $<0.01$ & $<0.01$ & $<0.01$ & $<0.01$ & $<0.01$ & $<0.01$ & $<0.01$ & $<0.01$ & $<0.01$ & $<0.01$ \\
\hline $\mathrm{Sb}_{2} \mathrm{O}_{3}$ & $<0.01$ & $<0.01$ & $<0.01$ & $<0.01$ & $<0.01$ & $<0.01$ & $<0.01$ & $<0.01$ & $<0.01$ & $<0.01$ & $<0.01$ \\
\hline $\mathrm{SeO}_{2}$ & $<0.01$ & $<0.01$ & $<0.01$ & $<0.01$ & $<0.01$ & $<0.01$ & $<0.01$ & $<0.01$ & $<0.01$ & $<0.01$ & $<0.01$ \\
\hline $\mathrm{SiO}_{2}$ & 41.10 & 41.08 & 41.82 & 41.59 & 41.59 & 41.09 & 40.90 & 41.36 & 41.47 & 41.46 & 41.58 \\
\hline $\mathrm{SnO}_{2}$ & $<0.01$ & $<0.01$ & $<0.01$ & $<0.01$ & $<0.01$ & $<0.01$ & $<0.01$ & $<0.01$ & $<0.01$ & $<0.01$ & $<0.01$ \\
\hline $\mathrm{SO}_{3}$ & 1.40 & 1.37 & 1.39 & 1.38 & 1.45 & 1.52 & 1.58 & 1.59 & 1.63 & 1.48 & 1.56 \\
\hline $\mathrm{SrO}$ & $<0.01$ & $<0.01$ & $<0.01$ & $<0.01$ & $<0.01$ & $<0.01$ & $<0.01$ & $<0.01$ & $<0.01$ & $<0.01$ & $<0.01$ \\
\hline $\mathrm{TiO}_{2}$ & 0.17 & 0.17 & 0.17 & 0.17 & 0.17 & 0.16 & 0.17 & 0.17 & 0.16 & 0.16 & 0.16 \\
\hline $\mathrm{V}_{2} \mathrm{O}_{5}$ & 2.02 & 2.01 & 1.94 & 1.98 & 2.02 & 2.00 & 2.01 & 2.01 & 2.07 & 1.94 & 1.99 \\
\hline $\mathrm{ZnO}$ & 3.27 & 3.24 & 3.12 & 3.18 & 3.29 & 3.22 & 3.24 & 3.21 & 3.35 & 3.15 & 3.24 \\
\hline $\mathrm{ZrO}_{2}$ & 3.27 & 3.25 & 3.05 & 3.09 & 3.26 & 3.25 & 3.32 & 3.25 & 3.16 & 3.04 & 3.27 \\
\hline Sum & 100.00 & 100.00 & 100.00 & 100.00 & 100.00 & 100.00 & 100.00 & 100.00 & 100.00 & 100.00 & 100.00 \\
\hline
\end{tabular}

* - Target values calculated based on simple well-stirred tank model

$\S$ - Not a target constituent 
Table 4.2. XRF Analyzed Compositions for DM10 Discharged Glass Samples (wt\%) (continued).

\begin{tabular}{|c|c|c|c|c|c|c|c|c|c|c|c|}
\hline Test & \multirow{2}{*}{\multicolumn{3}{|c|}{$\begin{array}{l}\mathrm{EE} \\
\mathrm{E}\end{array}$}} & \multicolumn{6}{|c|}{$2 A$} & \multicolumn{2}{|c|}{ 2B } \\
\hline Region & & & & \multicolumn{8}{|c|}{ A } \\
\hline Target $\mathrm{SO}_{3}$ & \multicolumn{3}{|c|}{1.625} & \multicolumn{6}{|c|}{0.10} & \multicolumn{2}{|c|}{0.20} \\
\hline Glass (kg) & 112.86 & 117.60 & 122.44 & 125.68 & 128.50 & 132.24 & 136.92 & 141.10 & 146.18 & 149.38 & 153.50 \\
\hline Constituent & $\begin{array}{c}\text { Q10-G- } \\
142 F\end{array}$ & $\begin{array}{c}\text { Q10-G- } \\
147 \mathrm{~B}\end{array}$ & $\begin{array}{c}\text { Q10-G } \\
148 \mathrm{~A}\end{array}$ & $\begin{array}{c}\text { R10-G- } \\
89 B\end{array}$ & $\begin{array}{c}\text { R10-G- } \\
\text { 89D }\end{array}$ & $\begin{array}{c}\text { R10-G- } \\
90 \mathrm{~B}\end{array}$ & $\begin{array}{c}\text { R10-G- } \\
90 \mathrm{E}\end{array}$ & $\begin{array}{c}\text { R10-G- } \\
91 B\end{array}$ & $\begin{array}{c}\text { R10-G- } \\
91 \mathrm{E}\end{array}$ & $\begin{array}{c}\text { R10-G- } \\
\text { 96A }\end{array}$ & $\begin{array}{c}\text { R10-G } \\
98 A\end{array}$ \\
\hline $\mathrm{Al}_{2} \mathrm{O}_{3}$ & 7.25 & 7.38 & 7.34 & 5.85 & 7.30 & 7.80 & 8.32 & 8.63 & 8.75 & 9.02 & 9.03 \\
\hline $\mathrm{As}_{2} \mathrm{O}_{5}$ & $<0.01$ & $<0.01$ & $<0.01$ & 0.12 & 0.10 & 0.07 & 0.05 & 0.04 & 0.03 & 0.02 & 0.01 \\
\hline $\mathrm{B}_{2} \mathrm{O}_{3} *$ & 9.80 & 9.81 & 9.81 & 9.15 & 9.03 & 8.91 & 8.82 & 8.76 & 8.72 & 8.70 & 8.68 \\
\hline $\mathrm{CaO}$ & 10.17 & 10.11 & 10.14 & 0.68 & 1.46 & 1.80 & 2.27 & 2.67 & 2.85 & 3.20 & 3.15 \\
\hline $\mathrm{Cl}$ & 0.03 & 0.03 & 0.02 & 0.09 & 0.20 & 0.27 & 0.36 & 0.42 & 0.46 & 0.46 & 0.46 \\
\hline $\mathrm{Cr}_{2} \mathrm{O}_{3}$ & 0.44 & 0.42 & 0.45 & 0.24 & 0.24 & 0.27 & 0.31 & 0.35 & 0.40 & 0.45 & 0.49 \\
\hline $\mathrm{Cs}_{2} \mathrm{O}$ & 0.18 & 0.23 & 0.22 & 0.05 & 0.09 & 0.08 & 0.10 & 0.11 & 0.10 & 0.12 & 0.12 \\
\hline $\mathrm{F}^{*}$ & 0.20 & 0.20 & 0.20 & $<0.01$ & $<0.01$ & $<0.01$ & $<0.01$ & $<0.01$ & $<0.01$ & $<0.01$ & $<0.01$ \\
\hline $\mathrm{Fe}_{2} \mathrm{O}_{3}$ & 0.36 & 0.39 & 0.39 & 10.95 & 8.55 & 7.03 & 5.22 & 4.29 & 3.28 & 2.64 & 2.40 \\
\hline I & $<0.01$ & $<0.01$ & $<0.01$ & $<0.01$ & 0.03 & 0.03 & 0.06 & 0.07 & 0.06 & 0.08 & 0.09 \\
\hline $\mathrm{K}_{2} \mathrm{O}$ & 0.61 & 0.58 & 0.61 & 0.15 & 0.27 & 0.33 & 0.40 & 0.46 & 0.48 & 0.54 & 0.52 \\
\hline $\mathrm{La}_{2} \mathrm{O}_{3}$ & $<0.01$ & $<0.01$ & $<0.01$ & 0.21 & 0.16 & 0.13 & 0.09 & 0.07 & 0.07 & 0.05 & 0.05 \\
\hline $\mathrm{Li}_{2} \mathrm{O}^{*}$ & 2.49 & 2.49 & 2.49 & 1.81 & 1.36 & 0.94 & 0.59 & 0.39 & 0.23 & 0.17 & 0.11 \\
\hline $\mathrm{MgO}$ & 0.99 & 1.00 & 0.94 & 1.13 & 1.11 & 1.08 & 0.94 & 0.98 & 0.96 & 0.93 & 0.94 \\
\hline $\mathrm{MnO}$ & 0.01 & 0.01 & 0.02 & 3.31 & 2.38 & 1.92 & 1.37 & 1.06 & 0.76 & 0.53 & 0.48 \\
\hline $\mathrm{Na}_{2} \mathrm{O}$ & 15.49 & 15.85 & 15.79 & 11.17 & 15.53 & 17.50 & 19.44 & 19.87 & 21.59 & 21.08 & 21.85 \\
\hline $\mathrm{Nd}_{2} \mathrm{O}_{3}$ & $<0.01$ & $<0.01$ & $<0.01$ & 0.14 & 0.10 & 0.08 & 0.06 & 0.04 & 0.03 & 0.03 & 0.02 \\
\hline $\mathrm{NiO}$ & 0.02 & 0.02 & 0.02 & 0.17 & 0.12 & 0.09 & 0.07 & 0.06 & 0.06 & 0.05 & 0.05 \\
\hline $\mathrm{P}_{2} \mathrm{O}_{5}$ & 0.18 & 0.17 & 0.19 & 0.12 & 0.09 & 0.08 & 0.06 & 0.05 & 0.05 & 0.03 & 0.04 \\
\hline $\mathrm{PbO}$ & $<0.01$ & $<0.01$ & $<0.01$ & 0.11 & 0.09 & 0.08 & 0.05 & 0.04 & 0.03 & 0.03 & 0.03 \\
\hline $\mathrm{Sb}_{2} \mathrm{O}_{3}$ & $<0.01$ & $<0.01$ & $<0.01$ & 0.25 & 0.21 & 0.15 & 0.10 & 0.08 & 0.05 & 0.04 & 0.03 \\
\hline $\mathrm{SeO}_{2}$ & $<0.01$ & $<0.01$ & $<0.01$ & 0.21 & $<0.01$ & 0.01 & 0.01 & 0.00 & 0.01 & 0.00 & 0.01 \\
\hline $\mathrm{SiO}_{2}$ & 41.52 & 40.99 & 41.07 & 50.38 & 45.62 & 44.77 & 43.56 & 42.47 & 41.67 & 40.59 & 40.24 \\
\hline $\mathrm{SnO}_{2}$ & $<0.01$ & $<0.01$ & $<0.01$ & $<0.01$ & 1.07 & 1.34 & 1.81 & 2.20 & 2.29 & 2.97 & 3.08 \\
\hline $\mathrm{SO}_{3}$ & 1.60 & 1.63 & 1.65 & 0.38 & 0.08 & 0.08 & 0.09 & 0.10 & 0.11 & 0.12 & 0.14 \\
\hline $\mathrm{SrO}$ & $<0.01$ & $<0.01$ & $<0.01$ & 0.74 & 0.58 & 0.45 & 0.32 & 0.25 & 0.16 & 0.12 & 0.10 \\
\hline $\mathrm{TiO}_{2}$ & 0.16 & 0.16 & 0.16 & 0.22 & 0.19 & 0.18 & 0.15 & 0.15 & 0.13 & 0.13 & 0.12 \\
\hline $\mathrm{V}_{2} \mathrm{O}_{5}$ & 2.01 & 1.98 & 2.01 & $<0.01$ & $<0.01$ & $<0.01$ & $<0.01$ & $<0.01$ & $<0.01$ & $<0.01$ & $<0.01$ \\
\hline $\mathrm{ZnO}$ & 3.22 & 3.19 & 3.20 & 1.93 & 2.13 & 2.13 & 2.23 & 2.41 & 2.40 & 2.63 & 2.57 \\
\hline $\mathrm{ZrO}_{2}$ & 3.28 & 3.37 & 3.28 & 0.41 & 1.90 & 2.39 & 3.14 & 4.00 & 4.28 & 5.26 & 5.21 \\
\hline Sum & 100.00 & 100.00 & 100.00 & 100.00 & 100.00 & 100.00 & 100.00 & 100.00 & 100.00 & 100.00 & 100.00 \\
\hline
\end{tabular}

* - Target values calculated based on simple well-stirred tank model

$\S$ - Not a target constituent 
Table 4.2. XRF Analyzed Compositions for DM10 Discharged Glass Samples (wt\%) (continued).

\begin{tabular}{|c|c|c|c|c|c|c|c|c|c|c|c|}
\hline Test & \multicolumn{4}{|c|}{$2 B$} & \multicolumn{7}{|c|}{$2 \mathrm{C}$} \\
\hline Region & \multicolumn{11}{|c|}{$\mathbf{A}$} \\
\hline Target $\mathrm{SO}_{3}$ & \multicolumn{4}{|c|}{0.20} & \multicolumn{7}{|c|}{0.30} \\
\hline Glass (kg) & 158.08 & 161.28 & 165.36 & 169.00 & 173.74 & 177.06 & 180.08 & 183.66 & 186.68 & 190.48 & 193.74 \\
\hline ronctituont & R10-G & R10-G- & R10-G & R10-G- & R10-G- & R10-G- & R10-G- & R10-G & R10-G- & R10-G- & R10-G \\
\hline / Constituent & $99 \mathrm{~A}$ & $99 \mathrm{C}$ & $100 \mathrm{~B}$ & $101 \mathrm{~B}$ & $104 \mathrm{~B}$ & $105 \mathrm{~B}$ & $105 \mathrm{D}$ & $107 \mathrm{~A}$ & 107C & $111 \mathrm{~A}$ & $112 \mathrm{~A}$ \\
\hline $\mathrm{Al}_{2} \mathrm{O}_{3}$ & 9.14 & 9.47 & 9.40 & 9.55 & 9.51 & 9.53 & 9.49 & 9.36 & 9.54 & 9.62 & 9.51 \\
\hline $\mathrm{As}_{2} \mathrm{O}_{5}$ & $<0.01$ & $<0.01$ & $<0.01$ & $<0.01$ & $<0.01$ & $<0.01$ & $<0.01$ & $<0.01$ & $<0.01$ & $<0.01$ & $<0.01$ \\
\hline $\mathrm{B}_{2} \mathrm{O}_{3}$ * & 8.66 & 8.66 & 8.65 & 8.65 & 8.64 & 8.64 & 8.64 & 8.63 & 8.63 & 8.63 & 8.63 \\
\hline $\mathrm{CaO}$ & 3.42 & 3.28 & 3.30 & 3.28 & 3.42 & 3.29 & 3.37 & 3.40 & 3.49 & 3.39 & 3.48 \\
\hline $\mathrm{Cl}$ & 0.49 & 0.49 & 0.50 & 0.47 & 0.44 & 0.43 & 0.43 & 0.43 & 0.42 & 0.40 & 0.45 \\
\hline $\mathrm{Cr}_{2} \mathrm{O}_{3}$ & 0.51 & 0.49 & 0.47 & 0.47 & 0.49 & 0.44 & 0.45 & 0.44 & 0.46 & 0.44 & 0.42 \\
\hline $\mathrm{Cs}_{2} \mathrm{O}$ & 0.12 & 0.13 & 0.11 & 0.12 & 0.12 & 0.09 & 0.10 & 0.11 & 0.10 & 0.10 & 0.10 \\
\hline $\mathrm{F}^{*}$ & $<0.01$ & $<0.01$ & $<0.01$ & $<0.01$ & $<0.01$ & $<0.01$ & $<0.01$ & $<0.01$ & $<0.01$ & $<0.01$ & $<0.01$ \\
\hline $\mathrm{Fe}_{2} \mathrm{O}_{3}$ & 2.02 & 1.75 & 1.46 & 1.33 & 1.36 & 1.17 & 1.20 & 1.17 & 1.19 & 1.11 & 1.08 \\
\hline $\mathrm{I}$ & 0.09 & 0.09 & 0.08 & 0.11 & 0.10 & 0.09 & 0.09 & 0.08 & 0.08 & 0.09 & 0.08 \\
\hline $\mathrm{K}_{2} \mathrm{O}$ & 0.56 & 0.55 & 0.55 & 0.54 & 0.56 & 0.53 & 0.53 & 0.53 & 0.56 & 0.53 & 0.55 \\
\hline $\mathrm{La}_{2} \mathrm{O}_{3}$ & 0.01 & 0.03 & $<0.01$ & 0.02 & $<0.01$ & $<0.01$ & $<0.01$ & $<0.01$ & $<0.01$ & 0.01 & $<0.01$ \\
\hline $\mathrm{Li}_{2} \mathrm{O}^{*}$ & 0.07 & 0.05 & 0.03 & 0.02 & 0.01 & 0.01 & 0.01 & 0.01 & $<0.01$ & $<0.01$ & $<0.01$ \\
\hline $\mathrm{MgO}$ & 0.95 & 1.00 & 1.01 & 0.83 & 0.75 & 0.96 & 0.85 & 0.97 & 0.98 & 0.96 & 0.82 \\
\hline $\mathrm{MnO}$ & 0.33 & 0.27 & 0.19 & 0.15 & 0.16 & 0.11 & 0.10 & 0.09 & 0.09 & 0.08 & 0.07 \\
\hline $\mathrm{Na}_{2} \mathrm{O}$ & 21.63 & 21.52 & 22.67 & 23.58 & 22.89 & 24.21 & 23.18 & 23.41 & 22.42 & 23.38 & 23.61 \\
\hline $\mathrm{Nd}_{2} \mathrm{O}_{3}$ & 0.01 & 0.02 & 0.02 & 0.01 & 0.01 & 0.01 & 0.01 & 0.01 & 0.01 & 0.01 & 0.01 \\
\hline $\mathrm{NiO}$ & 0.05 & 0.04 & 0.03 & 0.03 & 0.03 & 0.03 & 0.03 & 0.03 & 0.03 & 0.03 & 0.03 \\
\hline $\mathrm{P}_{2} \mathrm{O}_{5}$ & 0.03 & 0.03 & 0.03 & 0.03 & 0.02 & 0.03 & 0.02 & 0.02 & 0.02 & 0.02 & $<0.01$ \\
\hline $\mathrm{PbO}$ & 0.02 & 0.02 & 0.01 & 0.01 & 0.01 & 0.01 & 0.01 & 0.01 & 0.00 & 0.00 & 0.01 \\
\hline $\mathrm{Sb}_{2} \mathrm{O}_{3}$ & 0.02 & 0.01 & 0.01 & $<0.01$ & 0.01 & $<0.01$ & $<0.01$ & $<0.01$ & $<0.01$ & $<0.01$ & $<0.01$ \\
\hline $\mathrm{SeO}_{2}$ & 0.01 & 0.01 & 0.01 & 0.01 & 0.01 & 0.01 & 0.01 & 0.01 & 0.00 & 0.01 & 0.01 \\
\hline $\mathrm{SiO}_{2}$ & 39.93 & 40.64 & 40.77 & 40.03 & 40.03 & 40.20 & 40.34 & 39.93 & 40.38 & 39.98 & 40.20 \\
\hline $\mathrm{SnO}_{2}$ & 3.15 & 3.14 & 2.82 & 3.12 & 3.36 & 2.75 & 3.09 & 3.02 & 3.02 & 3.10 & 3.05 \\
\hline $\mathrm{SO}_{3}$ & 0.16 & 0.16 & 0.17 & 0.19 & 0.21 & 0.24 & 0.25 & 0.26 & 0.26 & 0.26 & 0.29 \\
\hline $\mathrm{SrO}$ & 0.07 & 0.05 & 0.03 & 0.03 & 0.03 & 0.02 & 0.02 & 0.01 & 0.01 & 0.01 & 0.01 \\
\hline $\mathrm{TiO}_{2}$ & 0.13 & 0.12 & 0.11 & 0.11 & 0.11 & 0.09 & 0.10 & 0.10 & 0.11 & 0.11 & 0.10 \\
\hline $\mathrm{V}_{2} \mathrm{O}_{5}$ & $<0.01$ & $<0.01$ & $<0.01$ & $<0.01$ & $<0.01$ & $<0.01$ & $<0.01$ & $<0.01$ & $<0.01$ & $<0.01$ & $<0.01$ \\
\hline $\mathrm{ZnO}$ & 2.72 & 2.54 & 2.45 & 2.47 & 2.63 & 2.38 & 2.50 & 2.54 & 2.57 & 2.52 & 2.56 \\
\hline $\mathrm{ZrO}_{2}$ & 5.69 & 5.42 & 5.10 & 4.84 & 5.08 & 4.72 & 5.18 & 5.44 & 5.64 & 5.22 & 4.96 \\
\hline Sum & 100.00 & 100.00 & 100.00 & 100.00 & 100.00 & 100.00 & 100.00 & 100.00 & 100.00 & 100.00 & 100.00 \\
\hline
\end{tabular}

* - Target values calculated based on simple well-stirred tank model

$\S$ - Not a target constituent 
Table 4.2. XRF Analyzed Compositions for DM10 Discharged Glass Samples (wt\%) (continued).

\begin{tabular}{|c|c|c|c|c|c|c|c|c|c|c|c|}
\hline Test & \multicolumn{5}{|c|}{$2 \mathrm{D}$} & \multicolumn{6}{|c|}{$2 E$} \\
\hline Region & \multicolumn{11}{|c|}{ A } \\
\hline Target $\mathrm{SO}_{3}$ & \multicolumn{5}{|c|}{0.40} & \multicolumn{6}{|c|}{0.50} \\
\hline Glass (kg) & \begin{tabular}{|l|}
197.50 \\
\end{tabular} & \begin{tabular}{|l|}
201.48 \\
\end{tabular} & \begin{tabular}{|l|}
205.52 \\
\end{tabular} & \begin{tabular}{|l|}
209.28 \\
\end{tabular} & \begin{tabular}{|l|}
213.88 \\
\end{tabular} & \begin{tabular}{|l|}
217.12 \\
\end{tabular} & \begin{tabular}{|l|}
220.44 \\
\end{tabular} & 223.46 & \begin{tabular}{|l|}
227.02 \\
\end{tabular} & \begin{tabular}{|l|}
230.64 \\
\end{tabular} & 234.82 \\
\hline Constituent & $\begin{array}{c}\text { R10-G- } \\
112 C\end{array}$ & $\begin{array}{c}\text { R10-G- } \\
114 \mathrm{~A}\end{array}$ & $\begin{array}{c}\text { R10-G- } \\
119 \mathrm{~A}\end{array}$ & $\begin{array}{c}\text { R10-G- } \\
119 \mathrm{C}\end{array}$ & $\begin{array}{c}\text { R10-G- } \\
\text { 119F }\end{array}$ & $\begin{array}{c}\text { R10-G- } \\
\text { 129B }\end{array}$ & $\begin{array}{c}\text { R10-G- } \\
\text { 129C }\end{array}$ & $\begin{array}{c}\text { R10-G- } \\
\text { 134B }\end{array}$ & $\begin{array}{c}\text { R10-G- } \\
134 \mathrm{D}\end{array}$ & \begin{tabular}{|c|} 
R10-G- \\
$135 A$
\end{tabular} & $\begin{array}{c}\text { R10-G- } \\
\text { 135B }\end{array}$ \\
\hline $\mathrm{Al}_{2} \mathrm{O}_{3}$ & 9.60 & 9.63 & 9.33 & 9.40 & 9.28 & 9.47 & 9.37 & 9.50 & 9.38 & 9.49 & 9.47 \\
\hline $\mathrm{As}_{2} \mathrm{O}_{5}$ & $<0.01$ & $<0.01$ & $<0.01$ & $<0.01$ & $<0.01$ & $<0.01$ & $<0.01$ & $<0.01$ & $<0.01$ & $<0.01$ & $<0.01$ \\
\hline $\mathrm{B}_{2} \mathrm{O}_{3} *$ & 8.63 & 8.63 & 8.62 & 8.62 & 8.62 & 8.62 & 8.61 & 8.61 & 8.61 & 8.61 & 8.61 \\
\hline $\mathrm{CaO}$ & 3.42 & 3.29 & 3.39 & 3.37 & 3.44 & 3.38 & 3.34 & 3.34 & 3.39 & 3.43 & 3.39 \\
\hline $\mathrm{Cl}$ & 0.39 & 0.61 & 0.46 & 0.45 & 0.43 & 0.19 & 0.28 & 0.31 & 0.37 & 0.40 & 0.38 \\
\hline $\mathrm{Cr}_{2} \mathrm{O}_{3}$ & 0.44 & 0.45 & 0.48 & 0.46 & 0.47 & 0.57 & 0.53 & 0.52 & 0.51 & 0.49 & 0.51 \\
\hline $\mathrm{Cs}_{2} \mathrm{O}$ & 0.11 & 0.11 & 0.11 & 0.12 & 0.12 & 0.06 & 0.08 & 0.09 & 0.09 & 0.11 & 0.09 \\
\hline $\mathrm{F}^{*}$ & $<0.01$ & $<0.01$ & $<0.01$ & $<0.01$ & $<0.01$ & $<0.01$ & $<0.01$ & $<0.01$ & $<0.01$ & $<0.01$ & $<0.01$ \\
\hline $\mathrm{Fe}_{2} \mathrm{O}_{3}$ & 1.09 & 1.02 & 1.09 & 1.06 & 1.06 & 1.38 & 1.30 & 1.23 & 1.18 & 1.13 & 1.09 \\
\hline I & 0.11 & 0.09 & 0.10 & 0.09 & 0.09 & 0.09 & 0.08 & 0.08 & 0.09 & 0.09 & 0.07 \\
\hline $\mathrm{K}_{2} \mathrm{O}$ & 0.56 & 0.58 & 0.54 & 0.54 & 0.54 & 0.53 & 0.53 & 0.54 & 0.55 & 0.56 & 0.55 \\
\hline $\mathrm{La}_{2} \mathrm{O}_{3}$ & $<0.01$ & $<0.01$ & $<0.01$ & $<0.01$ & $<0.01$ & $<0.01$ & 0.02 & $<0.01$ & $<0.01$ & $<0.01$ & 0.02 \\
\hline $\mathrm{Li}_{2} \mathrm{O}^{*}$ & $<0.01$ & $<0.01$ & $<0.01$ & $<0.01$ & $<0.01$ & $<0.01$ & $<0.01$ & $<0.01$ & $<0.01$ & $<0.01$ & $<0.01$ \\
\hline $\mathrm{MgO}$ & 0.84 & 1.12 & 1.02 & 1.03 & 1.09 & 0.89 & 0.93 & 0.94 & 1.05 & 0.99 & 0.91 \\
\hline $\mathrm{MnO}$ & 0.07 & 0.06 & 0.05 & 0.05 & 0.04 & 0.17 & 0.13 & 0.12 & 0.09 & 0.08 & 0.06 \\
\hline $\mathrm{Na}_{2} \mathrm{O}$ & 23.82 & 24.10 & 23.62 & \begin{tabular}{|l|}
23.31 \\
\end{tabular} & 22.91 & 23.15 & 22.90 & 22.50 & 23.18 & 22.18 & 22.82 \\
\hline $\mathrm{Nd}_{2} \mathrm{O}_{3}$ & 0.01 & 0.01 & $<0.01$ & 0.01 & $<0.01$ & 0.01 & 0.01 & 0.01 & $<0.01$ & 0.01 & 0.01 \\
\hline $\mathrm{NiO}$ & 0.03 & 0.03 & 0.03 & 0.03 & 0.03 & 0.06 & 0.05 & 0.04 & 0.04 & 0.03 & 0.03 \\
\hline $\mathrm{P}_{2} \mathrm{O}_{5}$ & 0.03 & $<0.01$ & 0.03 & 0.03 & 0.03 & 0.03 & 0.03 & 0.03 & 0.03 & 0.03 & 0.02 \\
\hline $\mathrm{PbO}$ & 0.01 & $<0.01$ & 0.01 & 0.01 & 0.01 & 0.01 & 0.01 & 0.01 & $<0.01$ & 0.01 & 0.01 \\
\hline $\mathrm{Sb}_{2} \mathrm{O}_{3}$ & $<0.01$ & $<0.01$ & $<0.01$ & $<0.01$ & $<0.01$ & 0.01 & 0.01 & 0.01 & $<0.01$ & $<0.01$ & $<0.01$ \\
\hline $\mathrm{SeO}_{2}$ & 0.01 & 0.01 & 0.01 & 0.01 & 0.01 & 0.01 & 0.01 & $<0.01$ & $<0.01$ & $<0.01$ & $<0.01$ \\
\hline $\mathrm{SiO}_{2}$ & 39.60 & 39.71 & 39.72 & 40.01 & 39.95 & 40.34 & 40.42 & 40.86 & 40.28 & 40.98 & 40.78 \\
\hline $\mathrm{SnO}_{2}$ & 3.35 & 2.88 & 3.08 & 3.09 & 3.24 & 2.99 & 3.06 & 3.02 & 2.86 & 2.96 & 2.90 \\
\hline $\mathrm{SO}_{3}$ & 0.29 & 0.33 & 0.35 & 0.35 & 0.37 & 0.36 & 0.41 & 0.44 & 0.48 & 0.47 & 0.50 \\
\hline $\mathrm{SrO}$ & 0.01 & 0.01 & $<0.01$ & 0.01 & $<0.01$ & 0.03 & 0.02 & 0.02 & 0.01 & 0.01 & 0.01 \\
\hline $\mathrm{TiO}_{2}$ & 0.10 & 0.10 & 0.10 & 0.10 & 0.11 & 0.11 & 0.11 & 0.11 & 0.11 & 0.11 & 0.11 \\
\hline $\mathrm{V}_{2} \mathrm{O}_{5}$ & $<0.01$ & $<0.01$ & $<0.01$ & $<0.01$ & $<0.01$ & 0.01 & $<0.01$ & $<0.01$ & 0.01 & $<0.01$ & $<0.01$ \\
\hline $\mathrm{ZnO}$ & 2.54 & 2.38 & 2.49 & 2.48 & 2.58 & 2.50 & 2.50 & 2.45 & 2.50 & 2.48 & 2.48 \\
\hline $\mathrm{ZrO}_{2}$ & 4.98 & 4.87 & 5.38 & 5.37 & 5.57 & 5.06 & 5.26 & 5.24 & 5.21 & 5.37 & 5.17 \\
\hline Sum & 100.00 & 100.00 & 100.00 & $\mid 100.00$ & 100.00 & 100.00 & 100.00 & 100.00 & 100.00 & 100.00 & 100.00 \\
\hline
\end{tabular}


Table 4.2. XRF Analyzed Compositions for DM10 Discharged Glass Samples (wt\%) (continued).

\begin{tabular}{|c|c|c|c|c|c|c|c|c|c|c|c|}
\hline Test & \multicolumn{7}{|c|}{$2 F$} & \multicolumn{4}{|c|}{ 3A } \\
\hline Region & \multicolumn{7}{|c|}{$\mathbf{A}$} & \multicolumn{4}{|c|}{ B } \\
\hline Target $\mathrm{SO}_{3}$ & \multicolumn{7}{|c|}{0.60} & \multicolumn{4}{|c|}{0.60} \\
\hline Glass (kg) & 238.84 & 242.40 & 245.02 & 248.58 & 252.50 & 255.38 & 257.02 & 259.44 & 265.38 & 271.00 & 275.26 \\
\hline Constituent & $\begin{array}{r}\text { R10-G } \\
148 \mathrm{~A}\end{array}$ & $\begin{array}{c}\text { R10-G- } \\
148 B\end{array}$ & $\begin{array}{c}\text { R10-G- } \\
149 A\end{array}$ & $\begin{array}{c}\text { R10-G- } \\
153 A\end{array}$ & $\begin{array}{r}\text { R10-G- } \\
153 \mathrm{C}\end{array}$ & $\begin{array}{c}\text { R10-G- } \\
155 \mathrm{~A}\end{array}$ & $\begin{array}{c}\text { R10-G- } \\
\text { 155B }\end{array}$ & $\begin{array}{c}\text { S10-G- } \\
14 \mathrm{~B}\end{array}$ & $\begin{array}{c}\text { S10-G- } \\
15 \mathrm{~A}\end{array}$ & $\begin{array}{c}\text { S10-G- } \\
15 \mathrm{C}\end{array}$ & $\begin{array}{c}\text { S10-G } \\
16 B\end{array}$ \\
\hline $\mathrm{Al}_{2} \mathrm{O}_{3}$ & 9.38 & 9.40 & 9.45 & 9.51 & 9.24 & 9.35 & 9.47 & 9.73 & 9.84 & 9.78 & 9.60 \\
\hline $\mathrm{As}_{2} \mathrm{O}_{5}$ & $<0.01$ & $<0.01$ & $<0.01$ & $<0.01$ & $<0.01$ & $<0.01$ & $<0.01$ & $<0.01$ & $<0.01$ & $<0.01$ & $<0.01$ \\
\hline $\mathrm{B}_{2} \mathrm{O}_{3} *$ & 8.61 & 8.60 & 8.60 & 8.60 & 8.60 & 8.60 & 8.60 & 8.58 & 8.55 & 8.53 & 8.52 \\
\hline $\mathrm{CaO}$ & 3.45 & 3.44 & 3.48 & 3.40 & 3.51 & 3.49 & 3.61 & 2.92 & 2.61 & 2.48 & 2.17 \\
\hline $\mathrm{Cl}$ & 0.26 & 0.28 & 0.40 & 0.43 & 0.39 & 0.39 & 0.42 & 0.23 & 0.19 & 0.17 & 0.16 \\
\hline $\mathrm{Cr}_{2} \mathrm{O}_{3}$ & 0.49 & 0.48 & 0.40 & 0.39 & 0.37 & 0.33 & 0.37 & 0.39 & 0.40 & 0.41 & 0.41 \\
\hline $\mathrm{Cs}_{2} \mathrm{O}$ & 0.09 & 0.10 & 0.11 & 0.11 & 0.11 & 0.11 & 0.11 & 0.10 & 0.10 & 0.13 & 0.12 \\
\hline $\mathrm{F}^{*}$ & $<0.01$ & $<0.01$ & $<0.01$ & $<0.01$ & $<0.01$ & $<0.01$ & $<0.01$ & 0.10 & 0.27 & 0.35 & 0.39 \\
\hline $\mathrm{Fe}_{2} \mathrm{O}_{3}$ & 1.16 & 1.16 & 1.19 & 1.07 & 1.14 & 1.05 & 1.15 & 1.02 & 1.05 & 1.08 & 1.02 \\
\hline $\mathrm{I}$ & 0.08 & 0.08 & 0.10 & 0.09 & 0.09 & 0.08 & 0.09 & 0.06 & 0.05 & 0.05 & 0.04 \\
\hline $\mathrm{K}_{2} \mathrm{O}$ & 0.55 & 0.54 & 0.56 & 0.55 & 0.55 & 0.56 & 0.58 & 0.49 & 0.43 & 0.42 & 0.35 \\
\hline $\mathrm{La}_{2} \mathrm{O}_{3}$ & 0.02 & $<0.01$ & $<0.01$ & $<0.01$ & $<0.01$ & $<0.01$ & $<0.01$ & $<0.01$ & $<0.01$ & $<0.01$ & $<0.01$ \\
\hline $\mathrm{Li}_{2} \mathrm{O}^{*}$ & $<0.01$ & $<0.01$ & $<0.01$ & $<0.01$ & $<0.01$ & $<0.01$ & $<0.01$ & $<0.01$ & $<0.01$ & $<0.01$ & $<0.01$ \\
\hline $\mathrm{MgO}$ & 0.87 & 0.97 & 1.05 & 1.10 & 1.11 & 0.99 & 0.86 & 1.05 & 1.13 & 1.07 & 1.19 \\
\hline $\mathrm{MnO}$ & 0.09 & 0.08 & 0.06 & 0.05 & 0.04 & 0.04 & 0.04 & 0.03 & 0.03 & 0.03 & 0.03 \\
\hline $\mathrm{Na}_{2} \mathrm{O}$ & 23.13 & 23.26 & 23.10 & 23.46 & 23.58 & 23.76 & 23.27 & 24.60 & 24.13 & 23.56 & 24.69 \\
\hline $\mathrm{Nd}_{2} \mathrm{O}_{3}$ & 0.01 & 0.01 & $<0.01$ & 0.01 & $<0.01$ & 0.01 & 0.01 & 0.01 & 0.01 & $<0.01$ & 0.01 \\
\hline $\mathrm{NiO}$ & 0.05 & 0.05 & 0.04 & 0.04 & 0.03 & 0.03 & 0.03 & 0.04 & 0.05 & 0.05 & 0.05 \\
\hline $\mathrm{P}_{2} \mathrm{O}_{5}$ & 0.03 & 0.01 & 0.03 & 0.03 & 0.02 & 0.01 & 0.02 & 0.09 & 0.16 & 0.19 & 0.22 \\
\hline $\mathrm{PbO}$ & 0.01 & 0.01 & 0.01 & 0.01 & 0.01 & 0.01 & 0.01 & 0.01 & 0.01 & 0.01 & 0.00 \\
\hline $\mathrm{Sb}_{2} \mathrm{O}_{3}$ & $<0.01$ & $<0.01$ & $<0.01$ & $<0.01$ & $<0.01$ & $<0.01$ & $<0.01$ & $<0.01$ & $<0.01$ & $<0.01$ & $<0.01$ \\
\hline $\mathrm{SeO}_{2}$ & $<0.01$ & $<0.01$ & $<0.01$ & $<0.01$ & $<0.01$ & $<0.01$ & 0.01 & 0.01 & 0.01 & 0.01 & 0.01 \\
\hline $\mathrm{SiO}_{2}$ & 40.05 & 39.93 & 39.53 & 39.63 & 39.15 & 39.49 & 39.19 & 39.42 & 39.74 & 39.65 & 39.58 \\
\hline $\mathrm{SnO}_{2}$ & 3.22 & 3.17 & 3.25 & 3.05 & 3.19 & 3.09 & 3.37 & 2.58 & 1.94 & 1.89 & 1.49 \\
\hline $\mathrm{SO}_{3}$ & 0.46 & 0.47 & 0.50 & 0.56 & 0.50 & 0.51 & 0.52 & 0.53 & 0.54 & 0.56 & 0.54 \\
\hline $\mathrm{SrO}$ & 0.01 & $<0.01$ & $<0.01$ & 0.01 & 0.01 & $<0.01$ & $<0.01$ & $<0.01$ & $<0.01$ & $<0.01$ & $<0.01$ \\
\hline $\mathrm{TiO}_{2}$ & 0.10 & 0.10 & 0.09 & 0.10 & 0.11 & 0.11 & 0.10 & 0.13 & 0.17 & 0.20 & 0.21 \\
\hline $\mathrm{V}_{2} \mathrm{O}_{5}$ & 0.00 & 0.01 & 0.00 & 0.01 & 0.00 & 0.00 & 0.00 & 0.55 & 1.09 & 1.41 & 1.66 \\
\hline $\mathrm{ZnO}$ & 2.56 & 2.57 & 2.53 & 2.50 & 2.60 & 2.59 & 2.76 & 2.43 & 2.39 & 2.46 & 2.32 \\
\hline $\mathrm{ZrO}_{2}$ & 5.33 & 5.27 & 5.52 & 5.31 & 5.65 & 5.39 & 5.42 & 4.88 & 5.11 & 5.51 & 5.22 \\
\hline Sum & 100.00 & 100.00 & 100.00 & 100.00 & 100.00 & 100.00 & 100.00 & 100.00 & 100.00 & 100.00 & 100.00 \\
\hline
\end{tabular}

* - Target values calculated based on simple well-stirred tank model

$\S$ - Not a target constituent 
Table 4.2. XRF Analyzed Compositions for DM10 Discharged Glass Samples (wt\%) (continued).

\begin{tabular}{|c|c|c|c|c|c|c|c|c|c|c|c|}
\hline Test & 3A & \multicolumn{6}{|c|}{$3 B$} & \multicolumn{4}{|c|}{$3 \mathrm{C}$} \\
\hline Region & \multicolumn{11}{|c|}{ B } \\
\hline Target $\mathrm{SO}_{3}$ & 0.60 & \multicolumn{6}{|c|}{0.70} & \multicolumn{4}{|c|}{0.85} \\
\hline Glass (kg) & 278.96 & 282.94 & 287.54 & \begin{tabular}{|l|}
292.28 \\
\end{tabular} & \begin{tabular}{|l|}
295.80 \\
\end{tabular} & \begin{tabular}{|l|}
299.34 \\
\end{tabular} & 301.20 & 303.26 & \begin{tabular}{|l|}
307.50 \\
\end{tabular} & \begin{tabular}{|l|}
311.36 \\
\end{tabular} & 315.78 \\
\hline Constituent & $\begin{array}{c}\text { S10-G- } \\
\text { 22A }\end{array}$ & $\begin{array}{c}\text { S10-G- } \\
30 \mathrm{~A}\end{array}$ & $\begin{array}{c}\text { S10-G- } \\
\text { 31A }\end{array}$ & $\begin{array}{c}\text { S10-G- } \\
\text { 32A }\end{array}$ & $\begin{array}{c}\text { S10-G- } \\
\text { 33B }\end{array}$ & \begin{tabular}{|c|} 
S10-G- \\
$36 B$
\end{tabular} & $\begin{array}{c}\text { S10-G- } \\
\text { 36C }\end{array}$ & \begin{tabular}{|c|} 
S10-G- \\
37B
\end{tabular} & $\begin{array}{c}\text { S10-G- } \\
39 B\end{array}$ & $\begin{array}{c}\text { S10-G- } \\
42 B\end{array}$ & $\begin{array}{c}\text { S10-G } \\
42 \mathrm{D}\end{array}$ \\
\hline $\mathrm{Al}_{2} \mathrm{O}_{3}$ & 9.69 & 9.93 & 9.83 & 9.94 & 9.98 & 10.02 & 9.87 & 9.92 & 9.85 & 9.92 & 9.69 \\
\hline $\mathrm{As}_{2} \mathrm{O}_{5}$ & $<0.01$ & $<0.01$ & $<0.01$ & $<0.01$ & $<0.01$ & $<0.01$ & $<0.01$ & $<0.01$ & $<0.01$ & $<0.01$ & $<0.01$ \\
\hline $\mathrm{B}_{2} \mathrm{O}_{3} *$ & 8.52 & 8.51 & 8.51 & 8.50 & 8.50 & 8.50 & 8.50 & 8.50 & 8.49 & 8.49 & 8.49 \\
\hline $\mathrm{CaO}$ & 2.20 & 2.45 & 2.44 & 2.25 & 2.07 & 2.04 & 2.04 & 1.94 & 2.03 & 1.99 & 2.03 \\
\hline $\mathrm{Cl}$ & 0.18 & 0.05 & 0.03 & 0.09 & 0.11 & 0.13 & 0.13 & 0.11 & 0.12 & 0.12 & 0.13 \\
\hline $\mathrm{Cr}_{2} \mathrm{O}_{3}$ & 0.43 & 0.77 & 0.78 & 0.66 & 0.56 & 0.55 & 0.53 & 0.53 & 0.58 & 0.52 & 0.57 \\
\hline $\mathrm{Cs}_{2} \mathrm{O}$ & 0.15 & 0.07 & 0.06 & 0.10 & 0.12 & 0.13 & 0.12 & 0.13 & 0.13 & 0.13 & 0.14 \\
\hline $\mathrm{F}^{*}$ & 0.42 & 0.43 & 0.45 & 0.46 & 0.46 & 0.46 & 0.46 & 0.47 & 0.47 & 0.47 & 0.47 \\
\hline $\mathrm{Fe}_{2} \mathrm{O}_{3}$ & 1.05 & 1.40 & 1.39 & 1.27 & 1.13 & 1.16 & 1.13 & 1.04 & 1.14 & 1.10 & 1.15 \\
\hline I & 0.04 & 0.05 & 0.05 & 0.04 & 0.04 & 0.04 & 0.03 & 0.03 & 0.03 & 0.02 & 0.03 \\
\hline $\mathrm{K}_{2} \mathrm{O}$ & 0.37 & 0.42 & 0.41 & 0.38 & 0.36 & 0.36 & 0.36 & 0.34 & 0.35 & 0.35 & 0.34 \\
\hline $\mathrm{La}_{2} \mathrm{O}_{3}$ & $<0.01$ & $<0.01$ & 0.02 & 0.01 & 0.01 & $<0.01$ & $<0.01$ & $<0.01$ & 0.01 & $<0.01$ & $<0.01$ \\
\hline $\mathrm{Li}_{2} \mathrm{O}^{*}$ & $<0.01$ & $<0.01$ & $<0.01$ & $<0.01$ & $<0.01$ & $<0.01$ & $<0.01$ & $<0.01$ & $<0.01$ & $<0.01$ & $<0.01$ \\
\hline $\mathrm{MgO}$ & 0.83 & 0.89 & 0.87 & 0.83 & 0.94 & 0.90 & 1.00 & 1.08 & 0.90 & 1.04 & 0.99 \\
\hline $\mathrm{MnO}$ & 0.03 & 0.13 & 0.14 & 0.09 & 0.06 & 0.06 & 0.05 & 0.04 & 0.04 & 0.04 & 0.04 \\
\hline $\mathrm{Na}_{2} \mathrm{O}$ & 23.74 & 22.98 & 23.32 & 23.30 & 23.29 & 23.41 & 23.77 & 24.33 & 23.06 & 23.70 & 22.97 \\
\hline $\mathrm{Nd}_{2} \mathrm{O}_{3}$ & $<0.01$ & 0.01 & 0.01 & 0.01 & 0.01 & 0.01 & 0.01 & $<0.01$ & 0.01 & $<0.01$ & $<0.01$ \\
\hline $\mathrm{NiO}$ & 0.05 & 0.14 & 0.15 & 0.11 & 0.08 & 0.09 & 0.08 & 0.09 & 0.10 & 0.09 & 0.09 \\
\hline $\mathrm{P}_{2} \mathrm{O}_{5}$ & 0.25 & 0.23 & 0.22 & 0.24 & 0.27 & 0.29 & 0.29 & 0.29 & 0.28 & 0.29 & 0.29 \\
\hline $\mathrm{PbO}$ & $<0.01$ & $<0.01$ & $<0.01$ & $<0.01$ & $<0.01$ & $<0.01$ & $<0.01$ & $<0.01$ & $<0.01$ & 0.01 & 0.01 \\
\hline $\mathrm{Sb}_{2} \mathrm{O}_{3}$ & $<0.01$ & $<0.01$ & $<0.01$ & $<0.01$ & $<0.01$ & $<0.01$ & $<0.01$ & $<0.01$ & $<0.01$ & $<0.01$ & $<0.01$ \\
\hline $\mathrm{SeO}_{2}$ & $<0.01$ & $<0.01$ & $<0.01$ & $<0.01$ & 0.01 & 0.01 & $<0.01$ & $<0.01$ & $<0.01$ & 0.01 & 0.01 \\
\hline $\mathrm{SiO}_{2}$ & 40.33 & \begin{tabular}{|l|}
39.93 \\
\end{tabular} & 39.72 & 39.90 & 40.23 & 39.85 & 40.22 & \begin{tabular}{|l|}
40.27 \\
\end{tabular} & \begin{tabular}{|l|}
40.10 \\
\end{tabular} & 39.97 & 39.56 \\
\hline $\mathrm{SnO}_{2}$ & 1.49 & 1.58 & 1.66 & 1.45 & 1.28 & 1.29 & 1.16 & 1.11 & 1.19 & 1.07 & 1.18 \\
\hline $\mathrm{SO}_{3}$ & 0.60 & 0.55 & 0.55 & 0.60 & 0.63 & 0.65 & 0.68 & 0.68 & 0.80 & 0.75 & 0.89 \\
\hline $\mathrm{SrO}$ & $<0.01$ & 0.01 & 0.02 & 0.01 & 0.01 & $<0.01$ & $<0.01$ & $<0.01$ & $<0.01$ & $<0.01$ & $<0.01$ \\
\hline $\mathrm{TiO}_{2}$ & 0.20 & 0.20 & 0.21 & 0.22 & 0.22 & 0.23 & 0.22 & 0.21 & 0.24 & 0.23 & 0.24 \\
\hline $\mathrm{V}_{2} \mathrm{O}_{5}$ & 1.83 & 1.59 & 1.53 & 1.81 & 1.92 & 1.98 & 2.02 & 1.92 & 2.12 & 2.10 & 2.21 \\
\hline $\mathrm{ZnO}$ & 2.38 & 2.51 & 2.48 & 2.43 & 2.37 & 2.41 & 2.35 & 2.21 & 2.44 & 2.37 & 2.54 \\
\hline $\mathrm{ZrO}_{2}$ & 5.20 & 5.16 & 5.18 & 5.29 & 5.33 & 5.44 & 4.98 & 4.78 & 5.51 & 5.22 & 5.96 \\
\hline Sum & 100.00 & 100.00 & 100.00 & 100.00 & 100.00 & 100.00 & 100.00 & \begin{tabular}{|l|}
100.00 \\
\end{tabular} & 100.00 & 100.00 & 100.00 \\
\hline
\end{tabular}

* - Target values calculated based on simple well-stirred tank model

$\S$ - Not a target constituent 
Table 4.2. XRF Analyzed Compositions for DM10 Discharged Glass Samples (wt\%) (continued).

\begin{tabular}{|c|c|c|c|c|c|c|c|c|c|c|c|}
\hline \multirow{4}{*}{\begin{tabular}{|c|} 
Lest \\
Region \\
Target $\mathrm{SO}_{3}$ \\
Glass $(\mathrm{kg})$
\end{tabular}} & \multicolumn{2}{|c|}{$3 C$} & \multicolumn{6}{|c|}{ 3D } & \multicolumn{3}{|c|}{ 4A } \\
\hline & \multicolumn{8}{|c|}{ B } & \multirow{2}{*}{\multicolumn{3}{|c|}{$\begin{array}{c}\mathbf{C} \\
0.80\end{array}$}} \\
\hline & \multicolumn{2}{|c|}{0.85} & \multicolumn{6}{|c|}{1.00} & & & \\
\hline & 319.76 & 325.46 & 329.22 & 333.66 & 337.36 & 341.62 & 345.50 & 347.82 & 351.7 & 354.82 & 358.44 \\
\hline Constituent & $\begin{array}{c}\text { S10-G- } \\
44 \mathrm{~B}\end{array}$ & $\begin{array}{c}\text { S10-G- } \\
45 \mathrm{~A}\end{array}$ & $\begin{array}{c}\text { S10-G- } \\
53 B\end{array}$ & $\begin{array}{c}\text { S10-G- } \\
57 \mathrm{~B}\end{array}$ & $\begin{array}{c}\text { S10-G- } \\
\text { 57D }\end{array}$ & $\begin{array}{c}\text { S10-G- } \\
58 \mathrm{~B}\end{array}$ & $\begin{array}{c}\text { S10-G } \\
59 \mathrm{~A}\end{array}$ & $\begin{array}{c}\mathrm{S} 10-\mathrm{G} \\
59 \mathrm{~B}\end{array}$ & $\begin{array}{c}\text { S10-G- } \\
70 \mathrm{~A}\end{array}$ & $\begin{array}{c}\text { S10-G- } \\
72 \mathrm{~A}\end{array}$ & $\begin{array}{c}\text { S10-G } \\
73 \mathrm{~A}\end{array}$ \\
\hline $\mathrm{Al}_{2} \mathrm{O}_{3}$ & 9.82 & 9.59 & 9.84 & 9.71 & 9.78 & 9.72 & 9.87 & 9.71 & 9.90 & 9.74 & 9.95 \\
\hline $\mathrm{As}_{2} \mathrm{O}_{5}$ & $<0.01$ & $<0.01$ & $<0.01$ & $<0.01$ & $<0.01$ & $<0.01$ & $<0.01$ & $<0.01$ & $<0.01$ & $<0.01$ & $<0.01$ \\
\hline $\mathrm{B}_{2} \mathrm{O}_{3} *$ & 8.48 & 8.48 & 8.48 & 8.47 & 8.47 & 8.47 & 8.47 & 8.47 & 8.47 & 8.48 & 8.48 \\
\hline $\mathrm{CaO}$ & 1.97 & 2.03 & 1.98 & 2.01 & 1.95 & 1.91 & 1.91 & 1.92 & 1.99 & 2.00 & 1.97 \\
\hline $\mathrm{Cl}$ & 0.14 & 0.14 & 0.09 & 0.11 & 0.13 & 0.13 & 0.14 & 0.15 & 0.18 & 0.34 & 0.35 \\
\hline $\mathrm{Cr}_{2} \mathrm{O}_{3}$ & 0.49 & 0.50 & 0.58 & 0.53 & 0.59 & 0.52 & 0.44 & 0.45 & 0.47 & 0.65 & 0.59 \\
\hline $\mathrm{Cs}_{2} \mathrm{O}$ & 0.14 & 0.16 & 0.14 & 0.15 & 0.15 & 0.16 & 0.16 & 0.16 & 0.17 & 0.18 & 0.14 \\
\hline $\mathrm{F}^{*}$ & 0.47 & 0.47 & 0.47 & 0.47 & 0.47 & 0.47 & 0.47 & 0.47 & 0.32 & 0.24 & 0.17 \\
\hline $\mathrm{Fe}_{2} \mathrm{O}_{3}$ & 1.08 & 1.13 & 1.12 & 1.13 & 1.08 & 1.06 & 1.11 & 1.05 & 1.11 & 1.14 & 1.12 \\
\hline I & 0.03 & 0.04 & 0.04 & 0.04 & 0.04 & 0.04 & 0.04 & 0.03 & 0.04 & 0.04 & 0.04 \\
\hline $\mathrm{K}_{2} \mathrm{O}$ & 0.34 & 0.34 & 0.35 & 0.35 & 0.34 & 0.33 & 0.33 & 0.32 & 0.39 & 0.46 & 0.48 \\
\hline $\mathrm{La}_{2} \mathrm{O}_{3}$ & 0.01 & $<0.01$ & $<0.01$ & $<0.01$ & $<0.01$ & $<0.01$ & $<0.01$ & $<0.01$ & 0.01 & 0.02 & $<0.01$ \\
\hline $\mathrm{Li}_{2} \mathrm{O}^{*}$ & $<0.01$ & $<0.01$ & $<0.01$ & $<0.01$ & $<0.01$ & $<0.01$ & $<0.01$ & $<0.01$ & $<0.01$ & $<0.01$ & $<0.01$ \\
\hline $\mathrm{MgO}$ & 0.98 & 0.99 & 0.97 & 0.93 & 0.92 & 1.03 & 0.92 & 0.95 & 0.84 & 0.84 & 0.95 \\
\hline $\mathrm{MnO}$ & 0.04 & 0.03 & 0.04 & 0.04 & 0.04 & 0.03 & 0.03 & 0.03 & 0.03 & 0.02 & 0.02 \\
\hline $\mathrm{Na}_{2} \mathrm{O}$ & 23.19 & 24.12 & 23.77 & 23.68 & 23.45 & 24.07 & 23.50 & 24.17 & 22.61 & 22.88 & 22.32 \\
\hline $\mathrm{Nd}_{2} \mathrm{O}_{3}$ & $<0.01$ & $<0.01$ & 0.01 & 0.01 & 0.01 & 0.01 & $<0.01$ & $<0.01$ & 0.01 & 0.01 & 0.01 \\
\hline $\mathrm{NiO}$ & 0.08 & 0.09 & 0.14 & 0.11 & 0.09 & 0.08 & 0.07 & 0.07 & 0.07 & 0.06 & 0.05 \\
\hline $\mathrm{P}_{2} \mathrm{O}_{5}$ & 0.30 & 0.30 & 0.30 & 0.28 & 0.30 & 0.29 & 0.29 & 0.29 & 0.29 & 0.28 & 0.27 \\
\hline $\mathrm{PbO}$ & $<0.01$ & 0.01 & $<0.01$ & $<0.01$ & $<0.01$ & 0.01 & $<0.01$ & $<0.01$ & 0.01 & 0.01 & 0.01 \\
\hline $\mathrm{Sb}_{2} \mathrm{O}_{3}$ & $<0.01$ & $<0.01$ & $<0.01$ & $<0.01$ & $<0.01$ & $<0.01$ & $<0.01$ & $<0.01$ & $<0.01$ & $<0.01$ & $<0.01$ \\
\hline $\mathrm{SeO}_{2}$ & 0.01 & 0.01 & 0.01 & $<0.01$ & 0.01 & 0.01 & $<0.01$ & 0.01 & 0.01 & $<0.01$ & 0.01 \\
\hline $\mathrm{SiO}_{2}$ & 40.18 & 38.90 & 39.72 & 39.59 & 39.75 & 39.32 & 40.39 & 39.57 & 40.24 & 38.99 & 40.06 \\
\hline $\mathrm{SnO}_{2}$ & 1.13 & 1.21 & 1.22 & 1.21 & 1.15 & 1.21 & 1.15 & 1.15 & 1.28 & 1.36 & 1.21 \\
\hline $\mathrm{SO}_{3}$ & 0.84 & 0.81 & 0.77 & 0.86 & 1.15 & 1.04 & 0.89 & 1.00 & 0.90 & 1.14 & 1.01 \\
\hline $\mathrm{SrO}$ & $<0.01$ & $<0.01$ & $<0.01$ & $<0.01$ & $<0.01$ & $<0.01$ & $<0.01$ & $<0.01$ & $<0.01$ & $<0.01$ & $<0.01$ \\
\hline $\mathrm{TiO}_{2}$ & 0.24 & 0.24 & 0.23 & 0.23 & 0.24 & 0.22 & 0.23 & 0.23 & 0.23 & 0.20 & 0.17 \\
\hline $\mathrm{V}_{2} \mathrm{O}_{5}$ & 2.11 & 2.30 & 2.19 & 2.21 & 2.16 & 2.13 & 2.10 & 2.17 & 2.27 & 2.30 & 2.29 \\
\hline $\mathrm{ZnO}$ & 2.36 & 2.55 & 2.41 & 2.44 & 2.38 & 2.34 & 2.30 & 2.38 & 2.49 & 2.57 & 2.51 \\
\hline $\mathrm{ZrO}_{2}$ & 5.58 & 5.58 & 5.15 & 5.44 & 5.36 & 5.40 & 5.18 & 5.27 & 5.66 & 6.07 & 5.80 \\
\hline Sum & 100.00 & 100.00 & 100.00 & 100.00 & 100.00 & 100.00 & 100.00 & 100.00 & 100.00 & 100.00 & 100.00 \\
\hline
\end{tabular}

* - Target values calculated based on simple well-stirred tank model

$\S$ - Not a target constituent 
Table 4.2. XRF Analyzed Compositions for DM10 Discharged Glass Samples (wt\%) (continued).

\begin{tabular}{|c|c|c|c|c|c|c|c|c|c|c|c|}
\hline Test & \multicolumn{4}{|c|}{ 4A } & \multicolumn{2}{|c|}{ 4B } & \multicolumn{5}{|c|}{$4 \mathrm{C}$} \\
\hline Region & \multicolumn{11}{|c|}{$\mathbf{C}$} \\
\hline Target $\mathrm{SO}_{3}$ & \multicolumn{4}{|c|}{0.80} & \multicolumn{2}{|c|}{0.00} & \multicolumn{5}{|c|}{0.70} \\
\hline Glass (kg) & 361.42 & 365.84 & 370.28 & 372.02 & 375.58 & \begin{tabular}{|l|}
378.48 \\
\end{tabular} & 382.54 & 385.58 & 389.14 & 393.14 & 396.14 \\
\hline Constituent & $\begin{array}{c}\text { S10-G- } \\
73 \mathrm{C}\end{array}$ & $\begin{array}{c}\text { S10-G- } \\
73 E\end{array}$ & $\begin{array}{c}\text { S10-G } \\
76 B\end{array}$ & \begin{tabular}{|c|} 
S10-G- \\
$76 \mathrm{C}$
\end{tabular} & $\begin{array}{c}\text { S10-G- } \\
82 \mathrm{~A}\end{array}$ & $\begin{array}{c}\text { S10-G- } \\
83 \mathrm{~A}\end{array}$ & $\begin{array}{c}\text { S10-G } \\
94 \mathrm{~A}\end{array}$ & $\begin{array}{c}\text { S10-G } \\
94 B\end{array}$ & $\begin{array}{c}\text { S10-G- } \\
95 B\end{array}$ & $\begin{array}{c}\text { S10-G- } \\
96 \mathrm{~A}\end{array}$ & $\begin{array}{c}\text { S10-G } \\
97 \mathrm{~A}\end{array}$ \\
\hline $\mathrm{Al}_{2} \mathrm{O}_{3}$ & 10.13 & 10.12 & 10.23 & 10.20 & 10.45 & 10.61 & 10.76 & 10.42 & 10.39 & 10.28 & 10.46 \\
\hline $\mathrm{As}_{2} \mathrm{O}_{5}$ & $<0.01$ & $<0.01$ & $<0.01$ & $<0.01$ & $<0.01$ & $<0.01$ & $<0.01$ & $<0.01$ & $<0.01$ & $<0.01$ & $<0.01$ \\
\hline $\mathrm{B}_{2} \mathrm{O}_{3}{ }^{*}$ & 8.48 & 8.48 & 8.49 & 8.49 & 8.53 & 8.56 & 8.54 & 8.53 & 8.52 & 8.51 & 8.51 \\
\hline $\mathrm{CaO}$ & 1.89 & 1.87 & 1.85 & 1.91 & 1.95 & 1.93 & 1.86 & 1.90 & 1.95 & 1.95 & 1.96 \\
\hline $\mathrm{Cl}$ & 0.37 & 0.47 & 0.43 & 0.43 & 0.30 & 0.33 & 0.32 & 0.37 & 0.40 & 0.42 & 0.44 \\
\hline $\mathrm{Cr}_{2} \mathrm{O}_{3}$ & 0.55 & 0.81 & 0.55 & 0.51 & 0.41 & 0.41 & 0.41 & 0.45 & 0.51 & 0.55 & 0.53 \\
\hline $\mathrm{Cs}_{2} \mathrm{O}$ & 0.13 & 0.15 & 0.13 & 0.13 & 0.11 & 0.12 & 0.10 & 0.12 & 0.12 & 0.13 & 0.12 \\
\hline $\mathrm{F}^{*}$ & 0.13 & 0.08 & 0.06 & 0.05 & 0.04 & 0.03 & 0.02 & 0.02 & 0.02 & 0.01 & 0.01 \\
\hline $\mathrm{Fe}_{2} \mathrm{O}_{3}$ & 1.05 & 1.05 & 1.03 & 1.06 & 1.09 & 1.09 & 1.04 & 1.05 & 1.10 & 1.12 & 1.14 \\
\hline I & 0.03 & 0.03 & 0.03 & 0.03 & 0.03 & 0.03 & 0.03 & 0.04 & 0.03 & 0.03 & 0.03 \\
\hline $\mathrm{K}_{2} \mathrm{O}$ & 0.48 & 0.54 & 0.52 & 0.53 & 0.55 & 0.57 & 0.55 & 0.56 & 0.58 & 0.58 & 0.57 \\
\hline $\mathrm{La}_{2} \mathrm{O}_{3}$ & $<0.01$ & $<0.01$ & $<0.01$ & $<0.01$ & $<0.01$ & $<0.01$ & $<0.01$ & $<0.01$ & $<0.01$ & $<0.01$ & 0.02 \\
\hline $\mathrm{Li}_{2} \mathrm{O}^{*}$ & $<0.01$ & $<0.01$ & $<0.01$ & $<0.01$ & $<0.01$ & $<0.01$ & $<0.01$ & $<0.01$ & $<0.01$ & $<0.01$ & $<0.01$ \\
\hline $\mathrm{MgO}$ & 0.99 & 0.96 & 0.98 & 0.91 & 0.81 & 0.82 & 0.86 & 0.83 & 0.90 & 0.88 & 0.91 \\
\hline $\mathrm{MnO}$ & 0.02 & 0.02 & 0.01 & 0.01 & 0.02 & 0.02 & 0.02 & 0.02 & 0.02 & 0.01 & 0.01 \\
\hline $\mathrm{Na}_{2} \mathrm{O}$ & 23.33 & 22.61 & 23.34 & 23.08 & 22.83 & 22.48 & 23.25 & 23.14 & 22.54 & 22.23 & 22.49 \\
\hline $\mathrm{Nd}_{2} \mathrm{O}_{3}$ & 0.01 & 0.01 & 0.01 & 0.01 & $<0.01$ & $<0.01$ & 0.01 & $<0.01$ & $<0.01$ & $<0.01$ & 0.01 \\
\hline $\mathrm{NiO}$ & 0.04 & 0.04 & 0.03 & 0.03 & 0.04 & 0.05 & 0.05 & 0.05 & 0.05 & 0.04 & 0.04 \\
\hline $\mathrm{P}_{2} \mathrm{O}_{5}$ & 0.28 & 0.28 & 0.26 & 0.26 & 0.26 & 0.27 & 0.26 & 0.28 & 0.26 & 0.26 & 0.27 \\
\hline $\mathrm{PbO}$ & $<0.01$ & $<0.01$ & $<0.01$ & 0.01 & $<0.01$ & $<0.01$ & $<0.01$ & $<0.01$ & $<0.01$ & $<0.01$ & $<0.01$ \\
\hline $\mathrm{Sb}_{2} \mathrm{O}_{3}$ & $<0.01$ & $<0.01$ & $<0.01$ & $<0.01$ & $<0.01$ & $<0.01$ & $<0.01$ & $<0.01$ & $<0.01$ & $<0.01$ & $<0.01$ \\
\hline $\mathrm{SeO}_{2}$ & $<0.01$ & 0.01 & 0.01 & 0.01 & $<0.01$ & 0.01 & 0.01 & 0.01 & 0.01 & 0.01 & $<0.01$ \\
\hline $\mathrm{SiO}_{2}$ & 40.36 & 39.63 & 40.20 & 40.39 & 41.08 & 41.16 & 41.17 & 41.03 & 40.94 & 40.59 & 40.50 \\
\hline $\mathrm{SnO}_{2}$ & 1.04 & 1.13 & 1.11 & 1.12 & 1.08 & 1.12 & 1.01 & 1.09 & 1.07 & 1.14 & 1.05 \\
\hline $\mathrm{SO}_{3}$ & 0.94 & 1.57 & 0.99 & 0.88 & 0.45 & 0.39 & 0.42 & 0.48 & 0.59 & 0.67 & 0.60 \\
\hline $\mathrm{SrO}$ & $<0.01$ & $<0.01$ & $<0.01$ & $<0.01$ & $<0.01$ & $<0.01$ & $<0.01$ & $<0.01$ & $<0.01$ & $<0.01$ & $<0.01$ \\
\hline $\mathrm{TiO}_{2}$ & 0.16 & 0.15 & 0.14 & 0.14 & 0.14 & 0.13 & 0.13 & 0.12 & 0.13 & 0.13 & 0.14 \\
\hline $\mathrm{V}_{2} \mathrm{O}_{5}$ & 2.13 & 2.18 & 2.13 & 2.18 & 2.19 & 2.19 & 2.12 & 2.17 & 2.25 & 2.26 & 2.26 \\
\hline $\mathrm{ZnO}$ & 2.33 & 2.35 & 2.31 & 2.39 & 2.42 & 2.47 & 2.32 & 2.35 & 2.46 & 2.54 & 2.53 \\
\hline $\mathrm{ZrO}_{2}$ & 5.13 & 5.45 & 5.18 & 5.24 & 5.22 & 5.23 & 4.73 & 4.98 & 5.18 & 5.64 & 5.39 \\
\hline Sum & 100.00 & 100.00 & 100.00 & 100.00 & 100.00 & 100.00 & 100.00 & 100.00 & 100.00 & 100.00 & 100.00 \\
\hline
\end{tabular}

* - Target values calculated based on simple well-stirred tank model

$\S$ - Not a target constituent 
Table 4.2. XRF Analyzed Compositions for DM10 Discharged Glass Samples (wt\%) (continued).

\begin{tabular}{|c|c|c|c|c|c|c|c|c|c|c|c|}
\hline Test & \multicolumn{2}{|c|}{$4 \mathrm{C}$} & \multicolumn{7}{|c|}{ 4D } & \multicolumn{2}{|c|}{$4 \mathrm{E}$} \\
\hline Region & \multicolumn{11}{|c|}{ C } \\
\hline Target $\mathrm{SO}_{3}$ & \multicolumn{2}{|c|}{0.70} & \multicolumn{7}{|c|}{0.90} & \multicolumn{2}{|c|}{0.00} \\
\hline Glass (kg) & 400.34 & 403.56 & 407.48 & 410.82 & 413.86 & 417.2 & 421.4 & 425.62 & 426.9 & 429.76 & 432.32 \\
\hline Constituent & $\begin{array}{c}\text { S10-G- } \\
\text { 101A }\end{array}$ & $\begin{array}{c}\text { S10-G- } \\
101 B\end{array}$ & $\begin{array}{c}\text { S10-G } \\
103 A\end{array}$ & \begin{tabular}{|c|} 
S10-G- \\
$103 C$
\end{tabular} & $\begin{array}{c}\text { S10-G- } \\
\text { 106B }\end{array}$ & \begin{tabular}{|c|} 
S10-G- \\
106D
\end{tabular} & $\begin{array}{c}\text { S10-G } \\
109 A\end{array}$ & $\begin{array}{c}\text { S10-G } \\
\text { 109B }\end{array}$ & \begin{tabular}{|c|} 
S10-G- \\
111A
\end{tabular} & \begin{tabular}{|c|} 
S10-G- \\
$113 B$
\end{tabular} & $\begin{array}{r}\text { S10-G } \\
117 \mathrm{~A}\end{array}$ \\
\hline$\overline{\mathrm{Al}_{2} \mathrm{O}_{3}}$ & 10.55 & 10.50 & 10.47 & 10.10 & 10.60 & 10.45 & 10.02 & 10.22 & 10.45 & 10.47 & 10.68 \\
\hline $\mathrm{As}_{2} \mathrm{O}_{5}$ & $<0.01$ & $<0.01$ & $<0.01$ & $<0.01$ & $<0.01$ & $<0.01$ & $<0.01$ & $<0.01$ & $<0.01$ & $<0.01$ & $<0.01$ \\
\hline $\mathrm{B}_{2} \mathrm{O}_{3} *$ & 8.51 & 8.50 & 8.50 & 8.49 & 8.49 & 8.48 & 8.48 & 8.48 & 8.48 & 8.52 & 8.55 \\
\hline $\mathrm{CaO}$ & 1.90 & 1.96 & 1.99 & 2.05 & 1.93 & 1.86 & 1.91 & 1.87 & 1.91 & 1.91 & 1.97 \\
\hline $\mathrm{Cl}$ & 0.43 & 0.41 & 0.42 & 0.49 & 0.47 & 0.45 & 0.62 & 0.49 & 0.41 & 0.29 & 0.38 \\
\hline $\mathrm{Cr}_{2} \mathrm{O}_{3}$ & 0.51 & 0.53 & 0.54 & 0.91 & 0.54 & 0.52 & 1.16 & 0.68 & 0.60 & 0.43 & 0.37 \\
\hline $\mathrm{Cs}_{2} \mathrm{O}$ & 0.12 & 0.11 & 0.12 & 0.15 & 0.11 & 0.13 & 0.15 & 0.15 & 0.14 & 0.13 & 0.11 \\
\hline $\mathrm{F}^{*}$ & 0.01 & 0.01 & 0.01 & 0.01 & 0.01 & 0.01 & 0.01 & 0.01 & 0.01 & 0.01 & 0.01 \\
\hline $\mathrm{Fe}_{2} \mathrm{O}_{3}$ & 1.07 & 1.10 & 1.14 & 1.23 & 1.09 & 1.03 & 1.08 & 1.03 & 1.08 & 1.11 & 1.11 \\
\hline I & 0.03 & 0.03 & 0.04 & 0.04 & 0.03 & 0.04 & 0.03 & 0.03 & 0.04 & 0.04 & 0.03 \\
\hline $\mathrm{K}_{2} \mathrm{O}$ & 0.56 & 0.59 & 0.59 & 0.63 & 0.58 & 0.56 & 0.64 & 0.57 & 0.57 & 0.56 & 0.58 \\
\hline $\mathrm{La}_{2} \mathrm{O}_{3}$ & $<0.01$ & $<0.01$ & $<0.01$ & $<0.01$ & $<0.01$ & $<0.01$ & $<0.01$ & 0.01 & $<0.01$ & $<0.01$ & $<0.01$ \\
\hline $\mathrm{Li}_{2} \mathrm{O}^{*}$ & $<0.01$ & $<0.01$ & $<0.01$ & $<0.01$ & $<0.01$ & $<0.01$ & $<0.01$ & $<0.01$ & $<0.01$ & $<0.01$ & $<0.01$ \\
\hline $\mathrm{MgO}$ & 0.85 & 0.84 & 0.86 & 0.88 & 0.94 & 0.86 & 0.90 & 0.92 & 0.93 & 0.95 & 1.00 \\
\hline $\mathrm{MnO}$ & 0.01 & 0.01 & 0.01 & 0.01 & 0.01 & 0.01 & 0.01 & 0.01 & 0.01 & 0.01 & 0.01 \\
\hline $\mathrm{Na}_{2} \mathrm{O}$ & 22.74 & 22.45 & 21.60 & 21.78 & 22.00 & 22.99 & 21.89 & 22.81 & 22.02 & 22.17 & 21.29 \\
\hline $\mathrm{Nd}_{2} \mathrm{O}_{3}$ & 0.01 & $<0.01$ & 0.01 & $<0.01$ & 0.01 & $<0.01$ & $<0.01$ & 0.01 & 0.01 & $<0.01$ & $<0.01$ \\
\hline $\mathrm{NiO}$ & 0.03 & 0.04 & 0.03 & 0.04 & 0.02 & 0.02 & 0.03 & 0.02 & 0.02 & 0.03 & 0.03 \\
\hline $\mathrm{P}_{2} \mathrm{O}_{5}$ & 0.26 & 0.25 & 0.26 & 0.26 & 0.27 & 0.25 & 0.28 & 0.25 & 0.26 & 0.26 & 0.27 \\
\hline $\mathrm{PbO}$ & $<0.01$ & $<0.01$ & $<0.01$ & $<0.01$ & 0.01 & 0.01 & $<0.01$ & $<0.01$ & $<0.01$ & $<0.01$ & $<0.01$ \\
\hline $\mathrm{Sb}_{2} \mathrm{O}_{3}$ & $<0.01$ & $<0.01$ & $<0.01$ & $<0.01$ & $<0.01$ & $<0.01$ & $<0.01$ & $<0.01$ & $<0.01$ & $<0.01$ & $<0.01$ \\
\hline $\mathrm{SeO}_{2}$ & 0.01 & $<0.01$ & 0.01 & 0.01 & 0.01 & 0.01 & 0.01 & 0.01 & 0.01 & 0.01 & $<0.01$ \\
\hline $\mathrm{SiO}_{2}$ & 40.78 & 40.88 & 40.88 & 38.98 & 40.92 & 40.35 & 39.24 & 39.81 & 40.43 & 40.87 & 41.69 \\
\hline $\mathrm{SnO}_{2}$ & 1.05 & 1.04 & 1.13 & 1.18 & 1.01 & 1.10 & 1.07 & 1.11 & 1.16 & 1.17 & 1.04 \\
\hline $\mathrm{SO}_{3}$ & 0.64 & 0.61 & 0.70 & 1.06 & 0.84 & 0.88 & 1.99 & 1.31 & 0.97 & 0.57 & 0.40 \\
\hline $\mathrm{SrO}$ & $<0.01$ & $<0.01$ & $<0.01$ & $<0.01$ & $<0.01$ & $<0.01$ & $<0.01$ & $<0.01$ & $<0.01$ & $<0.01$ & $<0.01$ \\
\hline $\mathrm{TiO}_{2}$ & 0.12 & 0.14 & 0.13 & 0.14 & 0.13 & 0.12 & 0.13 & 0.12 & 0.14 & 0.13 & 0.13 \\
\hline $\mathrm{V}_{2} \mathrm{O}_{5}$ & 2.18 & 2.28 & 2.29 & 2.50 & 2.24 & 2.15 & 2.36 & 2.18 & 2.20 & 2.19 & 2.27 \\
\hline $\mathrm{ZnO}$ & 2.42 & 2.56 & 2.61 & 2.80 & 2.47 & 2.36 & 2.48 & 2.37 & 2.44 & 2.45 & 2.50 \\
\hline $\mathrm{ZrO}_{2}$ & 5.21 & 5.17 & 5.68 & 6.26 & 5.29 & 5.36 & 5.53 & 5.52 & 5.70 & 5.72 & 5.59 \\
\hline Sum & 100.00 & 100.00 & 100.00 & 100.00 & 100.00 & 100.00 & 100.00 & 100.00 & 100.00 & 100.00 & 100.00 \\
\hline
\end{tabular}

* - Target values calculated based on simple well-stirred tank model

$\S$ - Not a target constituent 
Table 4.2. XRF Analyzed Compositions for DM10 Discharged Glass Samples (wt\%) (continued).

\begin{tabular}{|c|c|c|c|c|c|c|c|c|c|c|c|}
\hline Test & \multicolumn{7}{|c|}{$5 A$} & \multicolumn{4}{|c|}{ 5B } \\
\hline Region & \multicolumn{11}{|c|}{ D } \\
\hline Target $\mathrm{SO}_{3}$ & \multicolumn{7}{|c|}{0.70} & \multicolumn{4}{|c|}{0.90} \\
\hline Glass (kg) & 435.88 & 439.16 & 443.48 & 446.96 & 452.12 & 455.88 & 458.84 & 463.86 & 467.66 & 470.7 & 473.92 \\
\hline Constituent & \begin{tabular}{|c|} 
S10-G- \\
$132 A$
\end{tabular} & $\begin{array}{c}\text { S10-G- } \\
132 B\end{array}$ & $\begin{array}{c}\text { S10-G- } \\
134 \mathrm{~A}\end{array}$ & \begin{tabular}{|c|} 
S10-G- \\
$135 B$
\end{tabular} & \begin{tabular}{|c} 
S10-G- \\
136B
\end{tabular} & $\begin{array}{c}\text { S10-G- } \\
136 D\end{array}$ & $\begin{array}{c}\text { S10-G- } \\
139 A\end{array}$ & $\begin{array}{c}\text { S10-G- } \\
\text { 141B }\end{array}$ & \begin{tabular}{|c|} 
S10-G- \\
$144 \mathrm{~A}$
\end{tabular} & $\begin{array}{c}\text { S10-G- } \\
144 C\end{array}$ & $\begin{array}{r}\text { S10-G } \\
145 \mathrm{~A}\end{array}$ \\
\hline $\mathrm{Al}_{2} \mathrm{O}_{3}$ & \begin{tabular}{|l|}
10.72 \\
\end{tabular} & 10.40 & 10.31 & 10.29 & \begin{tabular}{|l|}
10.37 \\
\end{tabular} & 10.12 & 10.19 & 10.18 & 9.94 & 10.06 & 9.56 \\
\hline $\mathrm{As}_{2} \mathrm{O}_{5}$ & $<0.01$ & $<0.01$ & $<0.01$ & $<0.01$ & $<0.01$ & $<0.01$ & $<0.01$ & $<0.01$ & $<0.01$ & $<0.01$ & $<0.01$ \\
\hline $\mathrm{B}_{2} \mathrm{O}_{3} *$ & 9.61 & 10.30 & 10.93 & 11.27 & 11.60 & 11.75 & 11.84 & 11.92 & 11.96 & 11.99 & 12.01 \\
\hline $\mathrm{CaO}$ & 2.81 & 3.72 & 4.59 & 5.88 & 6.45 & 7.08 & 7.41 & 7.51 & 7.32 & 7.33 & 7.56 \\
\hline $\mathrm{Cl}$ & 0.24 & 0.26 & 0.26 & 0.28 & 0.27 & 0.27 & 0.27 & 0.25 & 0.25 & 0.25 & 0.26 \\
\hline $\mathrm{Cr}_{2} \mathrm{O}_{3}$ & 0.46 & 0.46 & 0.49 & 0.54 & 0.55 & 0.59 & 0.61 & 0.56 & 0.50 & 0.51 & 0.52 \\
\hline $\mathrm{Cs}_{2} \mathrm{O}$ & 0.11 & 0.11 & 0.11 & 0.12 & 0.14 & 0.13 & 0.15 & 0.13 & 0.13 & 0.13 & 0.13 \\
\hline $\mathrm{F}^{*}$ & 0.06 & 0.09 & 0.12 & 0.13 & 0.15 & 0.16 & 0.16 & 0.16 & 0.17 & 0.17 & 0.17 \\
\hline $\mathrm{Fe}_{2} \mathrm{O}_{3}$ & 1.12 & 1.12 & 1.06 & 1.12 & 1.14 & 1.17 & 1.17 & 1.10 & 1.06 & 1.04 & 1.09 \\
\hline $\mathrm{I}$ & 0.02 & 0.02 & 0.02 & 0.01 & $<0.01$ & $<0.01$ & $<0.01$ & $<0.01$ & $<0.01$ & $<0.01$ & $<0.01$ \\
\hline $\mathrm{K}_{2} \mathrm{O}$ & 0.52 & 0.50 & 0.44 & 0.43 & 0.42 & 0.39 & 0.40 & 0.38 & 0.34 & 0.35 & 0.36 \\
\hline $\mathrm{La}_{2} \mathrm{O}_{3}$ & $<0.01$ & $<0.01$ & $<0.01$ & $<0.01$ & $<0.01$ & $<0.01$ & $<0.01$ & $<0.01$ & $<0.01$ & $<0.01$ & $<0.01$ \\
\hline $\mathrm{Li}_{2} \mathrm{O}^{*}$ & $<0.01$ & $<0.01$ & $<0.01$ & $<0.01$ & $<0.01$ & $<0.01$ & $<0.01$ & $<0.01$ & $<0.01$ & $<0.01$ & $<0.01$ \\
\hline $\mathrm{MgO}$ & 1.02 & 1.02 & 1.08 & 1.05 & 1.03 & 0.98 & 0.90 & 0.90 & 0.98 & 0.97 & 0.92 \\
\hline $\mathrm{MnO}$ & 0.02 & 0.01 & 0.02 & 0.02 & 0.02 & 0.02 & 0.02 & 0.02 & 0.02 & 0.02 & 0.02 \\
\hline $\mathrm{Na}_{2} \mathrm{O}$ & 21.43 & 20.69 & 21.33 & 20.00 & 19.27 & 19.24 & 19.57 & 18.80 & 19.35 & 18.46 & 18.61 \\
\hline $\mathrm{Nd}_{2} \mathrm{O}_{3}$ & 0.01 & $<0.01$ & 0.01 & $<0.01$ & $<0.01$ & $<0.01$ & $<0.01$ & $<0.01$ & $<0.01$ & $<0.01$ & $<0.01$ \\
\hline $\mathrm{NiO}$ & 0.06 & 0.06 & 0.06 & 0.06 & 0.06 & 0.07 & 0.07 & 0.07 & 0.06 & 0.06 & 0.06 \\
\hline $\mathrm{P}_{2} \mathrm{O}_{5}$ & $\begin{array}{l}0.27 \\
\end{array}$ & 0.30 & 0.31 & 0.33 & 0.35 & 0.36 & 0.35 & 0.39 & 0.39 & 0.36 & 0.35 \\
\hline $\mathrm{PbO}$ & $<0.01$ & $<0.01$ & 0.01 & 0.01 & 0.01 & 0.01 & $<0.01$ & 0.01 & $<0.01$ & 0.01 & 0.01 \\
\hline $\mathrm{Sb}_{2} \mathrm{O}_{3}$ & $<0.01$ & $<0.01$ & \begin{tabular}{|c|}
$<0.01$ \\
\end{tabular} & $<0.01$ & $<0.01$ & $<0.01$ & $<0.01$ & $<0.01$ & $<0.01$ & $<0.01$ & $<0.01$ \\
\hline $\mathrm{SeO}_{2}$ & \begin{tabular}{|l}
0.01 \\
\end{tabular} & 0.01 & $<0.01$ & $<0.01$ & $<0.01$ & 0.01 & $<0.01$ & $<0.01$ & $<0.01$ & $<0.01$ & $<0.01$ \\
\hline $\mathrm{SiO}_{2}$ & \begin{tabular}{|l|}
40.49 \\
\end{tabular} & 40.29 & 39.33 & 39.14 & 38.75 & 38.26 & 37.85 & 39.15 & 39.62 & 40.38 & 40.13 \\
\hline $\mathrm{SnO}_{2}$ & 0.98 & 0.81 & 0.58 & 0.41 & 0.35 & 0.24 & 0.18 & 0.13 & 0.08 & 0.07 & 0.05 \\
\hline $\mathrm{SO}_{3}$ & 0.47 & 0.50 & 0.55 & 0.62 & 0.65 & 0.68 & 0.69 & 0.73 & 0.76 & 0.77 & 0.78 \\
\hline $\mathrm{SrO}$ & $<0.01$ & $<0.01$ & $<0.01$ & $<0.01$ & $<0.01$ & $<0.01$ & $<0.01$ & $<0.01$ & $<0.01$ & $<0.01$ & $<0.01$ \\
\hline $\mathrm{TiO}_{2}$ & 0.14 & 0.15 & 0.16 & 0.18 & 0.20 & 0.19 & 0.20 & 0.19 & 0.19 & 0.19 & 0.19 \\
\hline $\mathrm{V}_{2} \mathrm{O}_{5}$ & 1.94 & 1.87 & 1.62 & 1.51 & 1.42 & 1.39 & 1.31 & 1.21 & 1.12 & 1.12 & 1.12 \\
\hline $\mathrm{ZnO}$ & 2.47 & 2.63 & 2.60 & 2.86 & 3.02 & 3.20 & 3.19 & 3.04 & 2.89 & 2.86 & 3.05 \\
\hline $\mathrm{ZrO}_{2}$ & 4.99 & 4.68 & 4.03 & 3.74 & 3.78 & 3.70 & 3.47 & 3.16 & 2.89 & 2.89 & 3.03 \\
\hline Sum & 100.00 & 100.00 & 100.00 & 100.00 & 100.00 & 100.00 & 100.00 & 100.00 & 100.00 & 100.00 & 100.00 \\
\hline
\end{tabular}

* - Target values calculated based on simple well-stirred tank model

$\S$ - Not a target constituent 
Table 4.2. XRF Analyzed Compositions for DM10 Discharged Glass Samples (wt\%) (continued).

\begin{tabular}{|c|c|c|c|c|c|c|c|c|c|c|c|c|}
\hline Test & \multicolumn{2}{|c|}{ 5B } & \multicolumn{4}{|c|}{$5 \mathrm{C}$} & \multicolumn{6}{|c|}{ 5D } \\
\hline Region & \multicolumn{12}{|c|}{ D } \\
\hline Target $\mathrm{SO}_{3}$ & \multicolumn{2}{|c|}{0.90} & \multicolumn{4}{|c|}{1.10} & \multicolumn{6}{|c|}{1.30} \\
\hline Glass (kg) & 478.44 & 480.94 & 487.62 & 493.1 & 497.64 & 502.56 & 507.4 & 512.56 & 516.48 & 521.16 & 525.4 & 527.26 \\
\hline & S10-G- & S10-G- & T10-G- & T10-G & T10-G- & T10-G- & T10-G- & T10-G- & T10-G- & T10-G- & T10-G- & T10-G- \\
\hline Cons & $145 \mathrm{C}$ & $148 \mathrm{~A}$ & $13 \mathrm{~A}$ & $13 \mathrm{C}$ & $13 \mathrm{E}$ & $16 \mathrm{~A}$ & $18 \mathrm{~A}$ & $18 \mathrm{C}$ & $19 \mathrm{~A}$ & 19C & $23 \mathrm{~B}$ & $23 \mathrm{C}$ \\
\hline $\mathrm{Al}_{2} \mathrm{O}_{3}$ & 9.65 & 9.71 & 9.79 & 9.58 & 9.43 & 9.32 & 9.45 & 9.69 & 9.47 & 9.53 & 9.54 & 9.23 \\
\hline $\mathrm{As}_{2} \mathrm{O}_{5}$ & $<0.01$ & $<0.01$ & $<0.01$ & $<0.01$ & $<0.01$ & $<0.01$ & $<0.01$ & $<0.01$ & $<0.01$ & $<0.01$ & $<0.01$ & $<0.01$ \\
\hline $\mathrm{B}_{2} \mathrm{O}_{3} *$ & 12.02 & 12.03 & 12.03 & 12.03 & 12.03 & 12.02 & 12.01 & 12.00 & 12.00 & 12.00 & 12.00 & 12.00 \\
\hline $\mathrm{CaO}$ & 7.41 & 7.45 & 7.26 & 7.30 & 7.54 & 7.69 & 7.61 & 7.27 & 7.43 & 7.26 & 7.29 & 7.26 \\
\hline $\mathrm{Cl}$ & 0.26 & 0.25 & 0.13 & 0.19 & 0.22 & 0.23 & 0.23 & 0.23 & 0.23 & 0.24 & 0.28 & 0.31 \\
\hline $\mathrm{Cr}_{2} \mathrm{O}_{3}$ & 0.50 & 0.46 & 0.48 & 0.45 & 0.44 & 0.42 & 0.41 & 0.39 & 0.41 & 0.38 & 0.40 & 0.46 \\
\hline $\mathrm{Cs}_{2} \mathrm{O}$ & 0.14 & 0.15 & 0.11 & 0.11 & 0.12 & 0.13 & 0.11 & 0.11 & 0.14 & 0.11 & 0.14 & 0.12 \\
\hline $\mathrm{F}^{*}$ & 0.17 & 0.17 & 0.17 & 0.17 & 0.17 & 0.17 & 0.17 & 0.17 & 0.17 & 0.17 & 0.17 & 0.17 \\
\hline $\mathrm{Fe}_{2} \mathrm{O}_{3}$ & 1.05 & 1.04 & 1.12 & 1.08 & 1.15 & 1.12 & 1.08 & 1.08 & 1.07 & 0.99 & 1.07 & 1.05 \\
\hline I & $<0.01$ & $<0.01$ & 0.01 & $<0.01$ & $\begin{array}{c}<0.01 \\
\end{array}$ & $<0.01$ & $<0.01$ & $<0.01$ & $<0.01$ & $<0.01$ & $<0.01$ & $<0.01$ \\
\hline $\mathrm{K}_{2} \mathrm{O}$ & 0.34 & 0.34 & 0.36 & 0.34 & 0.34 & 0.34 & 0.35 & 0.34 & 0.33 & 0.32 & 0.32 & 0.32 \\
\hline $\mathrm{La}_{2} \mathrm{O}_{3}$ & $<0.01$ & $<0.01$ & $<0.01$ & $<0.01$ & $<0.01$ & $<0.01$ & $<0.01$ & $<0.01$ & $<0.01$ & $<0.01$ & $<0.01$ & $<0.01$ \\
\hline $\mathrm{Li}_{2} \mathrm{O}^{*}$ & $<0.01$ & $<0.01$ & $<0.01$ & $<0.01$ & $<0.01$ & $<0.01$ & $<0.01$ & $<0.01$ & $<0.01$ & $<0.01$ & $<0.01$ & $<0.01$ \\
\hline $\mathrm{MgO}$ & 0.94 & 0.94 & 0.89 & 0.87 & 0.98 & 0.93 & 0.98 & 1.00 & 0.97 & 1.04 & 1.05 & 1.02 \\
\hline $\mathrm{MnO}$ & 0.02 & 0.02 & 0.03 & 0.03 & 0.03 & 0.02 & 0.02 & 0.02 & 0.02 & 0.02 & 0.02 & 0.02 \\
\hline $\mathrm{Na}_{2} \mathrm{O}$ & 18.67 & 18.63 & 18.05 & 18.24 & 18.04 & 18.11 & 17.65 & 18.42 & 17.96 & 18.42 & 18.21 & 18.99 \\
\hline $\mathrm{Nd}_{2} \mathrm{O}_{3}$ & $<0.01$ & $<0.01$ & $<0.01$ & $<0.01$ & 0.01 & 0.01 & $<0.01$ & $<0.01$ & $<0.01$ & $<0.01$ & $<0.01$ & $<0.01$ \\
\hline $\mathrm{NiO}$ & 0.06 & 0.05 & 0.07 & 0.06 & 0.06 & 0.06 & 0.05 & 0.05 & 0.05 & 0.04 & 0.04 & 0.05 \\
\hline $\mathrm{P}_{2} \mathrm{O}_{5}$ & 0.36 & 0.34 & 0.34 & 0.35 & 0.33 & 0.34 & 0.35 & 0.34 & 0.35 & 0.35 & 0.35 & 0.35 \\
\hline $\mathrm{PbO}$ & 0.01 & 0.01 & 0.01 & 0.01 & 0.01 & 0.01 & 0.01 & 0.01 & 0.01 & 0.01 & $<0.01$ & 0.01 \\
\hline $\mathrm{Sb}_{2} \mathrm{O}_{3}$ & $<0.01$ & $<0.01$ & $<0.01$ & $<0.01$ & $<0.01$ & $<0.01$ & $<0.01$ & $<0.01$ & $<0.01$ & $<0.01$ & $<0.01$ & $<0.01$ \\
\hline $\mathrm{SeO}_{2}$ & $<0.01$ & $<0.01$ & $<0.01$ & $<0.01$ & $<0.01$ & $<0.01$ & $<0.01$ & $<0.01$ & $<0.01$ & $<0.01$ & $<0.01$ & $<0.01$ \\
\hline $\mathrm{SiO}_{2}$ & 40.49 & 40.59 & 41.10 & 41.27 & 40.70 & 40.67 & 41.42 & 41.19 & 41.31 & 41.50 & 41.26 & 40.29 \\
\hline $\mathrm{SnO}_{2}$ & 0.04 & 0.03 & 0.11 & 0.08 & 0.05 & 0.05 & 0.03 & 0.02 & 0.02 & 0.02 & 0.02 & 0.01 \\
\hline $\mathrm{SO}_{3}$ & 0.79 & 0.77 & 0.78 & 0.86 & 0.87 & 0.89 & 0.96 & 0.98 & 1.06 & 1.09 & 1.25 & 1.83 \\
\hline $\mathrm{SrO}$ & $<0.01$ & $<0.01$ & $<0.01$ & $<0.01$ & 0.01 & $<0.01$ & $<0.01$ & $<0.01$ & $<0.01$ & $<0.01$ & $<0.01$ & $<0.01$ \\
\hline $\mathrm{TiO}_{2}$ & 0.19 & 0.19 & 0.19 & 0.19 & 0.20 & 0.20 & 0.19 & 0.19 & 0.19 & 0.19 & 0.18 & 0.18 \\
\hline $\mathrm{V}_{2} \mathrm{O}_{5}$ & 1.09 & 1.06 & 1.14 & 1.09 & 1.13 & 1.12 & 1.09 & 1.03 & 1.07 & 1.02 & 0.99 & 1.01 \\
\hline $\mathrm{ZnO}$ & 2.93 & 2.91 & 2.91 & 2.86 & 3.05 & 3.09 & 2.99 & 2.83 & 2.92 & 2.72 & 2.76 & 2.79 \\
\hline $\mathrm{ZrO}_{2}$ & 2.87 & 2.86 & 2.92 & 2.84 & 3.08 & 3.07 & 2.83 & 2.63 & 2.82 & 2.57 & 2.67 & 2.53 \\
\hline Sum & 100.00 & 100.00 & 100.00 & 100.0 & 100.00 & 100.00 & 100.00 & 100.00 & 100.00 & 100.00 & 100.00 & 100.00 \\
\hline
\end{tabular}

* - Target values calculated based on simple well-stirred tank model

$\S$ - Not a target constituent 
Table 4.3. Compositions of Discharged Glass Samples During DM10 ORP LAW Tests with Maximum Sulfur Concentrations without Secondary Phases (wt\%).

\begin{tabular}{|c|c|c|c|c|c|c|c|c|c|}
\hline $\begin{array}{c}\text { Test } \\
\text { Segment }\end{array}$ & \multicolumn{3}{|c|}{$1 \mathrm{C}$} & \multicolumn{3}{|c|}{$2 \mathrm{~F}$} & \multicolumn{3}{|c|}{$3 C$} \\
\hline Region & \multicolumn{3}{|c|}{$\mathrm{E}$} & \multicolumn{3}{|c|}{ A } & \multicolumn{3}{|c|}{ B } \\
\hline Target $\mathrm{SO}_{3}$ & \multicolumn{3}{|c|}{1.50} & \multicolumn{3}{|c|}{0.60} & \multicolumn{3}{|c|}{0.85} \\
\hline Name & \multicolumn{3}{|c|}{ Q10-G-134A } & \multicolumn{3}{|c|}{ R10-G-155A } & \multicolumn{3}{|c|}{ S10-G-45A } \\
\hline Constituent & Target & XRF & \%Dev. & Target & XRF & \%Dev. & Target & XRF & \%Dev. \\
\hline $\mathrm{Al}_{2} \mathrm{O}_{3}$ & 7.57 & 7.58 & -0.04 & 9.45 & 9.35 & -1.02 & 9.98 & 9.59 & -4.00 \\
\hline $\mathrm{As}_{2} \mathrm{O}_{5}$ & $\S$ & $<0.01$ & $\mathrm{NC}$ & $\S$ & $<0.01$ & $\mathrm{NC}$ & $\S$ & $<0.01$ & $\mathrm{NC}$ \\
\hline $\mathrm{B}_{2} \mathrm{O}_{3}$ & 9.82 & $9.82 *$ & NC & 8.60 & $8.60^{*}$ & NC & 8.48 & 8.48* & NC \\
\hline $\mathrm{CaO}$ & 10.02 & 10.16 & 1.08 & 3.32 & 3.49 & 5.23 & 1.89 & 2.03 & 7.16 \\
\hline $\mathrm{Cl}$ & 0.02 & 0.03 & $\mathrm{NC}$ & 0.68 & 0.39 & NC & 0.11 & 0.14 & $\mathrm{NC}$ \\
\hline $\mathrm{Cr}_{2} \mathrm{O}_{3}$ & 0.50 & 0.48 & $\mathrm{NC}$ & 0.49 & 0.33 & NC & 0.53 & 0.50 & NC \\
\hline $\mathrm{Cs}_{2} \mathrm{O}$ & 0.15 & 0.16 & NC & 0.14 & 0.11 & NC & 0.14 & 0.16 & NC \\
\hline $\mathrm{F}$ & 0.20 & $0.20 *$ & NC & $\S$ & $<0.01^{*}$ & NC & 0.47 & $0.47^{*}$ & NC \\
\hline $\mathrm{Fe}_{2} \mathrm{O}_{3}$ & 0.24 & 0.43 & NC & 0.92 & 1.05 & NC & 0.96 & 1.13 & NC \\
\hline I & $\S$ & $<0.01$ & NC & $\S$ & 0.08 & NC & $\S$ & 0.04 & NC \\
\hline $\mathrm{K}_{2} \mathrm{O}$ & 0.54 & 0.63 & NC & 0.54 & 0.56 & NC & 0.11 & 0.34 & NC \\
\hline $\mathrm{La}_{2} \mathrm{O}_{3}$ & $\S$ & $<0.01$ & NC & $\S$ & $<0.01$ & NC & $\S$ & $<0.01$ & NC \\
\hline $\mathrm{Li}_{2} \mathrm{O}$ & 2.49 & $2.49 *$ & NC & $\S$ & $<0.01^{*}$ & NC & $\S$ & $<0.01^{*}$ & NC \\
\hline $\mathrm{MgO}$ & 1.04 & 0.95 & -8.73 & 0.92 & 0.99 & NC & 0.93 & 0.99 & NC \\
\hline $\mathrm{MnO}$ & $\S$ & 0.01 & NC & $\S$ & 0.04 & NC & 0.05 & 0.03 & NC \\
\hline $\mathrm{Na}_{2} \mathrm{O}$ & 16.00 & 15.45 & -3.44 & 24.00 & 23.76 & -1.01 & 24.00 & 24.12 & 0.50 \\
\hline $\mathrm{Nd}_{2} \mathrm{O}_{3}$ & $\S$ & $<0.01$ & NC & $\S$ & 0.01 & NC & $\S$ & $<0.01$ & NC \\
\hline $\mathrm{NiO}$ & $\S$ & 0.02 & NC & $\S$ & 0.03 & $\mathrm{NC}$ & 0.04 & 0.09 & NC \\
\hline $\mathrm{P}_{2} \mathrm{O}_{5}$ & 0.12 & 0.19 & NC & $\S$ & 0.01 & NC & 0.22 & 0.30 & NC \\
\hline $\mathrm{PbO}$ & $\S$ & $<0.01$ & NC & $\S$ & 0.01 & NC & $\S$ & 0.01 & NC \\
\hline $\mathrm{Sb}_{2} \mathrm{O}_{3}$ & $\S$ & $<0.01$ & NC & $\S$ & $<0.01$ & $\mathrm{NC}$ & $\S$ & $<0.01$ & NC \\
\hline $\mathrm{SeO}_{2}$ & $\S$ & $<0.01$ & NC & $\S$ & $<0.01$ & NC & $\S$ & 0.01 & NC \\
\hline $\mathrm{SiO}_{2}$ & 41.28 & 41.59 & 0.76 & 39.25 & 39.49 & 0.59 & 39.88 & 38.90 & -2.46 \\
\hline $\mathrm{SnO}_{2}$ & $\S$ & $<0.01$ & NC & 2.73 & 3.09 & 12.93 & 1.00 & 1.21 & 21.36 \\
\hline $\mathrm{SO}_{3}$ & 1.50 & 1.38 & -8.06 & 0.60 & 0.51 & NC & 0.85 & 0.81 & $\mathrm{NC}$ \\
\hline $\mathrm{SrO}$ & $\S$ & $<0.01$ & NC & $\S$ & $<0.01$ & NC & $\S$ & $<0.01$ & NC \\
\hline $\mathrm{TiO}_{2}$ & 0.01 & 0.17 & NC & $\S$ & 0.11 & NC & $\S$ & 0.24 & NC \\
\hline $\mathrm{V}_{2} \mathrm{O}_{5}$ & 1.74 & 1.98 & 13.72 & $\S$ & $<0.01$ & NC & 1.99 & 2.30 & 15.34 \\
\hline $\mathrm{ZnO}$ & 3.21 & 3.18 & -0.92 & 2.43 & 2.59 & 6.29 & 2.36 & 2.55 & 7.92 \\
\hline $\mathrm{ZrO}_{2}$ & 3.53 & 3.09 & -12.47 & 5.91 & 5.39 & -8.78 & 6.01 & 5.58 & -7.17 \\
\hline Sum & 100.00 & 100.00 & NC & 100.00 & 100.00 & NC & 100.00 & 100.00 & NC \\
\hline
\end{tabular}

* - Target values calculated based on simple well-stirred tank model

$\S$ - Not a target constituent

NC - not calculated 
Table 4.3. Compositions of Discharged Glass Samples During DM10 ORP LAW Tests with Maximum Sulfur Concentrations without Secondary Phases (wt\%) (continued).

\begin{tabular}{|c|c|c|c|c|c|c|}
\hline Test Segment & \multicolumn{3}{|c|}{$4 \mathrm{C}$} & \multicolumn{3}{|c|}{$5 \mathrm{C}$} \\
\hline Region & \multicolumn{3}{|c|}{$\mathrm{C}$} & \multicolumn{3}{|c|}{$\mathrm{D}$} \\
\hline Target $\mathrm{SO}_{3}$ & \multicolumn{3}{|c|}{0.70} & \multicolumn{3}{|c|}{1.10} \\
\hline Name & \multicolumn{3}{|c|}{ S10-G-101B } & \multicolumn{3}{|c|}{ T10-G-16A } \\
\hline Constituent & Target & XRF & \%Dev. & Target & XRF & \%Dev. \\
\hline $\mathrm{Al}_{2} \mathrm{O}_{3}$ & 10.02 & 10.50 & 4.78 & 10.15 & 9.32 & -8.10 \\
\hline $\mathrm{As}_{2} \mathrm{O}_{5}$ & $\S$ & $<0.01$ & NC & $\S$ & $<0.01$ & NC \\
\hline $\mathrm{B}_{2} \mathrm{O}_{3}$ & 8.50 & $8.50 *$ & $\mathrm{NC}$ & 12.02 & $12.02 *$ & NC \\
\hline $\mathrm{CaO}$ & 1.91 & 1.96 & 2.73 & 8.01 & 7.69 & -3.98 \\
\hline $\mathrm{Cl}$ & 0.62 & 0.41 & NC & 0.33 & 0.23 & $\mathrm{NC}$ \\
\hline $\mathrm{Cr}_{2} \mathrm{O}_{3}$ & 0.53 & 0.53 & $\mathrm{NC}$ & 0.50 & 0.42 & $\mathrm{NC}$ \\
\hline $\mathrm{Cs}_{2} \mathrm{O}$ & 0.14 & 0.11 & NC & 0.13 & 0.13 & NC \\
\hline $\mathrm{F}$ & 0.01 & $0.01^{*}$ & NC & 0.17 & $0.17^{*}$ & NC \\
\hline $\mathrm{Fe}_{2} \mathrm{O}_{3}$ & 0.97 & 1.10 & $\mathrm{NC}$ & 1.00 & 1.12 & 11.82 \\
\hline I & $\S$ & 0.03 & $\mathrm{NC}$ & $\S$ & $<<0.01$ & $\mathrm{NC}$ \\
\hline $\mathrm{K}_{2} \mathrm{O}$ & 0.54 & 0.59 & NC & 0.16 & 0.34 & $\mathrm{NC}$ \\
\hline $\mathrm{La}_{2} \mathrm{O}_{3}$ & $\S$ & $<0.01$ & NC & $\S$ & $<0.01$ & NC \\
\hline $\mathrm{Li}_{2} \mathrm{O}$ & $\S$ & $<0.01^{*}$ & $\mathrm{NC}$ & $\S$ & $<0.01^{*}$ & $\mathrm{NC}$ \\
\hline $\mathrm{MgO}$ & 0.93 & 0.84 & NC & 1.00 & 0.93 & -6.98 \\
\hline $\mathrm{MnO}$ & $\S$ & 0.01 & $\mathrm{NC}$ & $\S$ & 0.02 & $\mathrm{NC}$ \\
\hline $\mathrm{Na}_{2} \mathrm{O}$ & 23.57 & 22.45 & -4.77 & 21.00 & 18.11 & -13.76 \\
\hline $\mathrm{Nd}_{2} \mathrm{O}_{3}$ & $\S$ & $<0.01$ & $\mathrm{NC}$ & $\S$ & 0.01 & $\mathrm{NC}$ \\
\hline $\mathrm{NiO}$ & $\S$ & 0.04 & NC & 0.04 & 0.06 & $\mathrm{NC}$ \\
\hline $\mathrm{P}_{2} \mathrm{O}_{5}$ & 0.18 & 0.25 & $\mathrm{NC}$ & 0.28 & 0.34 & NC \\
\hline $\mathrm{PbO}$ & $\S$ & $<0.01$ & NC & 0.01 & 0.01 & $\mathrm{NC}$ \\
\hline $\mathrm{Sb}_{2} \mathrm{O}_{3}$ & $\S$ & $<0.01$ & NC & $\S$ & $<0.01$ & $\mathrm{NC}$ \\
\hline $\mathrm{SeO}_{2}$ & $\S$ & $<0.01$ & $\mathrm{NC}$ & $\S$ & $<0.01$ & $\mathrm{NC}$ \\
\hline $\mathrm{SiO}_{2}$ & 40.01 & 40.88 & 2.18 & 37.11 & 40.67 & 9.60 \\
\hline $\mathrm{SnO}_{2}$ & 1.00 & 1.04 & 4.65 & $\S$ & 0.05 & NC \\
\hline $\mathrm{SO}_{3}$ & 0.70 & 0.61 & NC & 1.10 & 0.89 & $\mathrm{NC}$ \\
\hline $\mathrm{SrO}$ & $\S$ & $<0.01$ & NC & $\S$ & $<0.01$ & NC \\
\hline $\mathrm{TiO}_{2}$ & $\S$ & 0.14 & NC & $\S$ & 0.20 & NC \\
\hline $\mathrm{V}_{2} \mathrm{O}_{5}$ & 2.00 & 2.28 & 14.21 & 1.00 & 1.12 & 11.71 \\
\hline $\mathrm{ZnO}$ & 2.36 & 2.56 & 8.27 & 3.00 & 3.09 & 3.08 \\
\hline $\mathrm{ZrO}_{2}$ & 6.03 & 5.17 & -14.20 & 3.00 & 3.07 & 2.43 \\
\hline Sum & 100.00 & 100.00 & NC & 100.00 & 100.00 & NC \\
\hline
\end{tabular}

* - Target values calculated based on simple well-stirred tank model

$\S$ - Not a target constituent

NC - not calculated 
Table 4.4. DCP Analyzed Compositions of Discharged Glass Samples During DM10 ORP LAW Tests with Maximum Sulfur Concentrations without Secondary Phases (wt\%)

\begin{tabular}{|c|c|c|c|c|c|c|c|c|c|}
\hline Test & \multicolumn{3}{|c|}{ 1C } & \multicolumn{3}{|c|}{$2 F$} & \multicolumn{3}{|c|}{$3 C$} \\
\hline Region & \multicolumn{3}{|c|}{$\mathbf{E}$} & \multicolumn{3}{|c|}{ A } & \multicolumn{3}{|c|}{ B } \\
\hline Target $\mathrm{SO}_{3}$ & \multicolumn{3}{|c|}{1.50} & \multicolumn{3}{|c|}{0.60} & \multicolumn{3}{|c|}{0.85} \\
\hline Name & \multicolumn{3}{|c|}{ Q10-G-134A } & \multicolumn{3}{|c|}{ R10-G-155A } & \multicolumn{3}{|c|}{ S10-G-45A } \\
\hline Constituent & Target & XRF & DCP & Target & XRF & DCP & Target & XRF & DCP \\
\hline $\mathrm{Al}_{2} \mathrm{O}_{3}$ & 7.59 & 7.58 & 6.82 & 9.45 & 9.35 & 8.74 & 9.98 & 9.59 & 8.86 \\
\hline $\mathrm{As}_{2} \mathrm{O}_{5}$ & $\S$ & $<0.01$ & 0.03 & $\S$ & $<0.01$ & $<0.01$ & $\S$ & $<0.01$ & $<0.01$ \\
\hline $\mathrm{B}_{2} \mathrm{O}_{3}$ & 9.85 & $9.82 *$ & 9.76 & 8.60 & $8.60^{*}$ & 8.92 & 8.48 & $8.48 *$ & 8.56 \\
\hline $\mathrm{CaO}$ & 10.05 & 10.16 & 10.15 & 3.32 & 3.49 & 3.37 & 1.89 & 2.03 & 1.96 \\
\hline $\mathrm{Cl}$ & 0.02 & 0.03 & 0.03 & 0.68 & 0.39 & NA & 0.11 & 0.14 & NA \\
\hline $\mathrm{Cr}_{2} \mathrm{O}_{3}$ & 0.25 & 0.48 & 0.39 & 0.49 & 0.33 & 0.27 & 0.53 & 0.50 & 0.37 \\
\hline $\mathrm{Cs}_{2} \mathrm{O}$ & 0.15 & 0.16 & $0.15^{* *}$ & 0.14 & 0.11 & $0.07 * *$ & 0.14 & 0.16 & $0.11^{* *}$ \\
\hline F & 0.20 & $0.20 *$ & NA & $\S$ & $<0.01^{*}$ & NA & 0.47 & $0.47 *$ & NA \\
\hline $\mathrm{Fe}_{2} \mathrm{O}_{3}$ & 0.24 & 0.43 & 0.44 & 0.92 & 1.05 & 1.09 & 0.96 & 1.13 & 1.09 \\
\hline I & $\S$ & $<0.01$ & NA & $\S$ & 0.08 & NA & $\S$ & 0.04 & NA \\
\hline $\mathrm{K}_{2} \mathrm{O}$ & 0.54 & 0.63 & 0.69 & 0.54 & 0.56 & 0.64 & 0.11 & 0.34 & 0.40 \\
\hline $\mathrm{La}_{2} \mathrm{O}_{3}$ & $\S$ & $<0.01$ & NA & $\S$ & $<0.01$ & NA & $\S$ & $<0.01$ & NA \\
\hline $\mathrm{Li}_{2} \mathrm{O}$ & 2.50 & $2.49 *$ & 2.85 & $\S$ & $<0.01 *$ & 0.08 & $\S$ & $<0.01 *$ & 0.05 \\
\hline $\mathrm{MgO}$ & 1.05 & 0.95 & 1.02 & 0.92 & 0.99 & 1.10 & 0.93 & 0.99 & 0.92 \\
\hline $\mathrm{MnO}$ & $\S$ & 0.01 & 0.02 & $\S$ & 0.04 & 0.04 & 0.05 & 0.03 & 0.03 \\
\hline $\mathrm{Na}_{2} \mathrm{O}$ & 16.00 & 15.45 & 13.66 & 24.00 & 23.76 & 20.11 & 24.00 & 24.12 & 20.07 \\
\hline $\mathrm{Nd}_{2} \mathrm{O}_{3}$ & $\S$ & $<0.01$ & NA & $\S$ & 0.01 & NA & $\S$ & $<0.01$ & NA \\
\hline $\mathrm{NiO}$ & $\S$ & 0.02 & 0.03 & $\S$ & 0.03 & 0.03 & 0.04 & 0.09 & 0.09 \\
\hline $\mathrm{P}_{2} \mathrm{O}_{5}$ & 0.12 & 0.19 & 0.32 & $\S$ & 0.01 & 0.25 & 0.22 & 0.30 & 0.25 \\
\hline $\mathrm{PbO}$ & $\S$ & $<0.01$ & 0.01 & $\S$ & 0.01 & 0.01 & $\S$ & 0.01 & 0.01 \\
\hline $\mathrm{Sb}_{2} \mathrm{O}_{3}$ & $\S$ & $<0.01$ & 0.05 & $\S$ & $<0.01$ & 0.04 & $\S$ & $<0.01$ & 0.04 \\
\hline $\mathrm{SeO}_{2}$ & $\S$ & $<0.01$ & 0.01 & $\S$ & $<0.01$ & $<0.01$ & $\S$ & 0.01 & 0.04 \\
\hline $\mathrm{SiO}_{2}$ & 41.41 & 41.59 & 40.52 & 39.25 & 39.49 & 39.70 & 39.88 & 38.90 & 39.44 \\
\hline $\mathrm{SnO}_{2}$ & $\S$ & $<0.01$ & 0.03 & 2.73 & 3.09 & 2.83 & 1.00 & 1.21 & 1.14 \\
\hline $\mathrm{SO}_{3}$ & 1.50 & 1.38 & NA & 0.60 & 0.51 & NA & 0.85 & 0.81 & NA \\
\hline $\mathrm{SrO}$ & $\S$ & $<0.01$ & 0.01 & $\S$ & $<0.01$ & 0.01 & $\S$ & $<0.01$ & 0.01 \\
\hline $\mathrm{TiO}_{2}$ & 0.01 & 0.17 & 0.17 & $\S$ & 0.11 & 0.12 & $\S$ & 0.24 & 0.23 \\
\hline $\mathrm{V}_{2} \mathrm{O}_{5}$ & 1.75 & 1.98 & 1.84 & $\S$ & $<0.01$ & 0.02 & 1.99 & 2.30 & 2.03 \\
\hline $\mathrm{ZnO}$ & 3.22 & 3.18 & 3.21 & 2.43 & 2.59 & 2.45 & 2.36 & 2.55 & 2.33 \\
\hline $\mathrm{ZrO}_{2}$ & 3.54 & 3.09 & 3.10 & 5.91 & 5.39 & 5.14 & 6.01 & 5.58 & 5.05 \\
\hline Sum & \begin{tabular}{|l|}
100.00 \\
\end{tabular} & 100.00 & 95.31 & 100.00 & 100.00 & 95.03 & \begin{tabular}{|l|}
100.00 \\
\end{tabular} & \begin{tabular}{|l|}
100.00 \\
\end{tabular} & 93.08 \\
\hline
\end{tabular}


Table 4.4. DCP Analyzed Compositions of Discharged Glass Samples During DM10 ORP LAW Tests with Maximum Sulfur Concentrations without Secondary Phases (wt\%) (continued).

\begin{tabular}{|c|c|c|c|c|c|c|}
\hline Test & \multicolumn{3}{|c|}{$4 \mathrm{C}$} & \multicolumn{3}{|c|}{$5 C$} \\
\hline Region & \multicolumn{3}{|c|}{$\mathbf{C}$} & \multicolumn{3}{|c|}{$\mathbf{D}$} \\
\hline Target $\mathrm{SO}_{3}$ & \multicolumn{3}{|c|}{0.70} & \multicolumn{3}{|c|}{1.10} \\
\hline Name & \multicolumn{3}{|c|}{ S10-G-101B } & \multicolumn{3}{|c|}{ T10-G-16A } \\
\hline Constituent & Target & XRF & DCP & Target & XRF & DCP \\
\hline $\mathrm{Al}_{2} \mathrm{O}_{3}$ & 10.02 & 10.50 & 9.59 & 10.15 & 9.32 & 8.61 \\
\hline $\mathrm{As}_{2} \mathrm{O}_{5}$ & $\S$ & $<0.01$ & $<0.01$ & $\S$ & $<0.01$ & $<0.01$ \\
\hline $\mathrm{B}_{2} \mathrm{O}_{3}$ & 8.50 & $8.50 *$ & 8.47 & 12.02 & 12.02* & 12.27 \\
\hline $\mathrm{CaO}$ & 1.91 & 1.96 & 1.87 & 8.01 & 7.69 & 7.07 \\
\hline $\mathrm{Cl}$ & 0.62 & 0.41 & NA & 0.33 & 0.23 & NA \\
\hline $\mathrm{Cr}_{2} \mathrm{O}_{3}$ & 0.53 & 0.53 & 0.41 & 0.50 & 0.42 & 0.32 \\
\hline $\mathrm{Cs}_{2} \mathrm{O}$ & 0.14 & 0.11 & $0.10^{* *}$ & 0.13 & 0.13 & $0.08^{* *}$ \\
\hline $\mathrm{F}$ & 0.01 & $0.01^{*}$ & NA & 0.17 & $0.17 *$ & NA \\
\hline $\mathrm{Fe}_{2} \mathrm{O}_{3}$ & 0.97 & 1.10 & 1.06 & 1.00 & 1.12 & 1.04 \\
\hline $\mathrm{I}$ & $\S$ & 0.03 & NA & $\S$ & $<0.01$ & NA \\
\hline $\mathrm{K}_{2} \mathrm{O}$ & 0.54 & 0.59 & 0.67 & 0.16 & 0.34 & 0.38 \\
\hline $\mathrm{La}_{2} \mathrm{O}_{3}$ & $\S$ & $<0.01$ & NA & $\S$ & $<0.01$ & NA \\
\hline $\mathrm{Li}_{2} \mathrm{O}$ & $\S$ & $<0.01^{*}$ & 0.04 & $\S$ & $<0.01^{*}$ & 0.06 \\
\hline $\mathrm{MgO}$ & 0.93 & 0.84 & 0.90 & 1.00 & 0.93 & 1.04 \\
\hline $\mathrm{MnO}$ & $\S$ & 0.01 & 0.01 & $\S$ & 0.02 & 0.02 \\
\hline $\mathrm{Na}_{2} \mathrm{O}$ & 23.57 & 22.45 & 19.30 & 21.00 & 18.11 & 15.47 \\
\hline $\mathrm{Nd}_{2} \mathrm{O}_{3}$ & $\S$ & $<0.01$ & NA & $\S$ & 0.01 & NA \\
\hline $\mathrm{NiO}$ & $\S$ & 0.04 & 0.05 & 0.04 & 0.06 & 0.06 \\
\hline $\mathrm{P}_{2} \mathrm{O}_{5}$ & 0.18 & 0.25 & 0.28 & 0.28 & 0.34 & 0.26 \\
\hline $\mathrm{PbO}$ & $\S$ & $<0.01$ & 0.01 & 0.01 & 0.01 & 0.03 \\
\hline $\mathrm{Sb}_{2} \mathrm{O}_{3}$ & $\S$ & $<0.01$ & 0.05 & $\S$ & $<0.01$ & 0.05 \\
\hline $\mathrm{SeO}_{2}$ & $\S$ & $<0.01$ & 0.04 & $\S$ & $<0.01$ & 0.05 \\
\hline $\mathrm{SiO}_{2}$ & 40.01 & 40.88 & 40.35 & 37.11 & 40.67 & 40.45 \\
\hline $\mathrm{SnO}_{2}$ & 1.00 & 1.04 & 1.14 & $\S$ & 0.05 & 0.05 \\
\hline $\mathrm{SO}_{3}$ & 0.70 & 0.61 & NA & 1.10 & 0.89 & NA \\
\hline $\mathrm{SrO}$ & $\S$ & $<0.01$ & $<0.01$ & $\S$ & $<0.01$ & 0.01 \\
\hline $\mathrm{TiO}_{2}$ & $\S$ & 0.14 & 0.14 & $\S$ & 0.20 & 0.19 \\
\hline $\mathrm{V}_{2} \mathrm{O}_{5}$ & 2.00 & 2.28 & 2.06 & 1.00 & 1.12 & 0.99 \\
\hline $\mathrm{ZnO}$ & 2.36 & 2.56 & 2.32 & 3.00 & 3.09 & 2.72 \\
\hline $\mathrm{ZrO}_{2}$ & 6.03 & 5.17 & 4.96 & 3.00 & 3.07 & 2.71 \\
\hline Sum & 100.00 & 100.00 & 93.82 & 100.00 & 100.00 & 93.93 \\
\hline
\end{tabular}

$\S$ - Not a target constituent

* - Target values calculated based on simple well-stirred tank model

** - Analyzed by Atomic Absorption

NA - Not analyzed

NC - Not calculated 
Table 4.5. Listing of Dip Samples and Presence of Sulfate Layer During DM10 Melter Tests.

\begin{tabular}{|c|c|c|c|c|c|c|c|c|c|}
\hline \multirow{2}{*}{ Test } & \multirow{2}{*}{ Region } & \multirow{2}{*}{$\begin{array}{c}\text { Sampling } \\
\text { Date }\end{array}$} & \multicolumn{5}{|c|}{ Target (wt\%) } & \multirow{2}{*}{ Sample Name } & \multirow{2}{*}{$\begin{array}{c}\text { Secondary Phase } \\
\text { Observed }\end{array}$} \\
\hline & & & $\mathrm{SO}_{3}$ & F & $\mathrm{Cl}$ & $\mathrm{Cr}_{2} \mathrm{O}_{3}$ & $\mathrm{P}_{2} \mathrm{O}_{5}$ & & \\
\hline \multirow{6}{*}{$1 \mathrm{~A}$} & \multirow{23}{*}{$\mathbf{E}$} & \multirow{10}{*}{$1 / 24 / 07$} & \multirow{6}{*}{1.25} & \multirow{6}{*}{0.20} & \multirow{6}{*}{0.02} & \multirow{6}{*}{0.50} & \multirow{6}{*}{0.12} & Q10-D-118A & YES \\
\hline & & & & & & & & Q10-D-118B & YES \\
\hline & & & & & & & & Q10-D-118C & $\mathrm{NO}$ \\
\hline & & & & & & & & Q10-D-118D & YES \\
\hline & & & & & & & & Q10-D-119A & YES \\
\hline & & & & & & & & Q10-D-119B & NO \\
\hline \multirow{5}{*}{ 1B } & & & \multirow{5}{*}{1.50} & \multirow{5}{*}{0.20} & \multirow{5}{*}{0.02} & \multirow{5}{*}{0.50} & \multirow{5}{*}{0.12} & Q10-D-127A & NO \\
\hline & & & & & & & & Q10-D-127B & NO \\
\hline & & & & & & & & Q10-D-127C & YES \\
\hline & & & & & & & & Q10-D-127D & TRACE \\
\hline & & \multirow{4}{*}{$1 / 25 / 07$} & & & & & & Q10-D-127E & NO \\
\hline \multirow{3}{*}{ 1C } & & & & & & & & Q10-D-134A & NO \\
\hline & & & 1.50 & 0.20 & 0.02 & 0.25 & 0.12 & Q10-D-134B & NO \\
\hline & & & & & & & & Q10-D-134C & NO \\
\hline & & & & & & & & Q10-D-141A & NO \\
\hline & & & & & & & & Q10-D-141B & NO \\
\hline $1 D$ & & $1 / 26 / 07$ & 1.75 & 0.20 & 0.02 & 0.25 & 0.12 & Q10-D-141C & YES \\
\hline & & & & & & & & Q10-D-141D & YES \\
\hline & & & & & & & & Q10-D-141E & NO \\
\hline & & & & & & & & Q10-D-148A & NO \\
\hline & & 1 & 1670 & (2) 0 & רם ח & זבר 0 & 017 & Q10-D-148B & NO \\
\hline $1 \mathrm{E}$ & & $1 / 26 / 07$ & 1.625 & 0.20 & 0.02 & 0.25 & 0.12 & Q10-D-148C & YES \\
\hline & & & & & & & & Q10-D-148D & NO \\
\hline & & & & & & & & R10-D-95A & NO \\
\hline $2 A$ & & 6/6/07 & 0.10 & 0.20 & 0.02 & 0.50 & 0.12 & R10-D-95B & NO \\
\hline & & & & & & & & R10-D-95C & NO \\
\hline & & & & & & & & R10-D-101A & NO \\
\hline $2 B$ & & $6 / 7 / 07$ & 0.20 & 0.20 & 0.02 & 0.50 & 0.12 & R10-D-101B & NO \\
\hline & & & & & & & & R10-D-101C & NO \\
\hline & & & & & & & & R10-D-111A & NO \\
\hline $2 \mathrm{C}$ & & & 0.30 & 0.00 & 0.68 & 0.49 & 0.00 & R10-D-111B & NO \\
\hline & & & & & & & & R10-D-111C & NO \\
\hline & A & 6/8/07 & & & & & & R10-D-122A & $\mathrm{NO}$ \\
\hline & & & & & & & & R10-D-122B & $\mathrm{NO}$ \\
\hline 2D & & & 0.40 & 0.00 & 0.68 & 0.49 & 0.00 & R10-D-122C & NO \\
\hline & & & & & & & & R10-D-122D & $\mathrm{NO}$ \\
\hline & & & & & & & & R10-D-136A & NO \\
\hline & & & & & & & & R10-D-136B & NO \\
\hline & & & & & & & & R10-D-136C & NO \\
\hline $2 \mathbf{E}$ & & 6/12/07 & 0.50 & 0.00 & 0.68 & 0.49 & 0.00 & R10-D-136D & $\mathrm{NO}$ \\
\hline & & & & & & & & R10-D-136E & NO \\
\hline & & & & & & & & R10-D-136F & NO \\
\hline
\end{tabular}


Table 4.5. Listing of Dip Samples and Presence of Sulfate Layer During DM10 Melter Tests (continued).

\begin{tabular}{|c|c|c|c|c|c|c|c|c|c|}
\hline \multirow{2}{*}{ Test } & \multirow{2}{*}{ Region } & \multirow{2}{*}{$\begin{array}{c}\text { Sampling } \\
\text { Date }\end{array}$} & \multicolumn{5}{|c|}{ Target (wt\%) } & \multirow{2}{*}{ Sample Name } & \multirow{2}{*}{$\begin{array}{c}\text { Secondary Phase } \\
\text { Observed }\end{array}$} \\
\hline & & & $\mathrm{SO}_{3}$ & $\mathrm{~F}$ & $\mathrm{Cl}$ & $\mathrm{Cr}_{2} \mathrm{O}_{3}$ & $\mathrm{P}_{2} \mathrm{O}_{5}$ & & \\
\hline \multirow{4}{*}{$2 \mathbf{F}$} & \multirow{4}{*}{$\mathbf{A}$} & $6 / 14 / 07$ & \multirow{4}{*}{0.60} & \multirow{4}{*}{0.00} & \multirow{4}{*}{0.68} & \multirow{4}{*}{0.49} & \multirow{4}{*}{0.00} & R10-D-147A & NO \\
\hline & & \multirow{6}{*}{$6 / 15 / 07$} & & & & & & R10-D-155A & NO \\
\hline & & & & & & & & R10-D-155B & $\mathrm{NO}$ \\
\hline & & & & & & & & R10-D-155C & $\mathrm{NO}$ \\
\hline \multirow{3}{*}{$\mathbf{3 A}$} & & & \multirow{3}{*}{0.60} & \multirow{3}{*}{0.47} & \multirow{3}{*}{0.11} & \multirow{3}{*}{0.53} & \multirow{3}{*}{0.22} & S10-D-16A & $\mathrm{NO}$ \\
\hline & & & & & & & & S10-D-16B & $\mathrm{NO}$ \\
\hline & & & & & & & & S10-D-16C & $\mathrm{NO}$ \\
\hline \multirow{3}{*}{ 3B } & & \multirow{3}{*}{ 6/29/07 } & & & & & & S10-D-36A & $\mathrm{NO}$ \\
\hline & & & 0.70 & 0.47 & 0.11 & 0.53 & 0.22 & S10-D-36B & NO \\
\hline & & & & & & & & S10-D-36C & $\mathrm{NO}$ \\
\hline & & & & & & & & S10-D-45A & $\mathrm{NO}$ \\
\hline $3 C$ & & 6/30/07 & 0.85 & 0.47 & 0.11 & 0.53 & 0.22 & S10-D-45B & $\mathrm{NO}$ \\
\hline & & & & & & & & S10-D-45C & $\mathrm{NO}$ \\
\hline & & & & & & & & S10-D-45D & $\mathrm{NO}$ \\
\hline & B & & & & & & & S10-D-59A & YES \\
\hline & & & & & & & & S10-D-59B & YES \\
\hline & & & & & & & & S10-D-59C & YES \\
\hline & & & & & & & & S10-D-60A & $\mathrm{NO}$ \\
\hline 3D & & $7 / 2 / 07$ & 1.00 & 0.47 & 0.11 & 0.53 & 0.22 & S10-D-60B & TRACE \\
\hline & & & & & & & & S10-D-60C & YES \\
\hline & & & & & & & & S10-D-60D & TRACE \\
\hline & & & & & & & & S10-D-60E & TRACE \\
\hline & & & & & & & & S10-D-60F & NO \\
\hline & & & & & & & & S10-D-60G & NO \\
\hline & & & & & & & & S10-D-76A & YES \\
\hline & & & & & & & & S10-D-76B & YES \\
\hline & & & & & & & & S10-D-76C & YES \\
\hline & & & & & & & & S10-D-77A & NO \\
\hline & & & & & & & & S10-D-77B & TRACE \\
\hline & & & & & & & & S10-D-77C & NO \\
\hline & & & & & & & & S10-D-77D & YES \\
\hline & & & & & & & & S10-D-77E & TRACE \\
\hline & & & & & & & & S10-D-77F & YES \\
\hline $4 A$ & C & 7/3/07 & 0.80 & 0.01 & 0.62 & 0.53 & 0.18 & S10-D-77G & NO \\
\hline & & & & & & & & S10-D-78A & YES \\
\hline & & & & & & & & S10-D-78B & YES \\
\hline & & & & & & & & S10-D-78C & YES \\
\hline & & & & & & & & S10-D-78D & NO \\
\hline & & & & & & & & S10-D-78E & NO \\
\hline & & & & & & & & S10-D-78F & YES \\
\hline & & & & & & & & S10-D-78G & $\mathrm{NO}$ \\
\hline & & & & & & & & S10-D-78H & TRACE \\
\hline & & & & & & & & S10-D-78I & YES \\
\hline
\end{tabular}


Table 4.5. Listing of Dip Samples and Presence of Sulfate Layer During DM10 Melter Tests (continued).

\begin{tabular}{|c|c|c|c|c|c|c|c|c|c|}
\hline \multirow{2}{*}{ Test } & \multirow{2}{*}{ Region } & \multirow{2}{*}{$\begin{array}{c}\text { Sampling } \\
\text { Date }\end{array}$} & \multicolumn{5}{|c|}{ Target (wt\%) } & \multirow{2}{*}{ Sample Name } & \multirow{2}{*}{$\begin{array}{c}\text { Secondary Phase } \\
\text { Observed }\end{array}$} \\
\hline & & & $\mathrm{SO}_{3}$ & $\mathrm{~F}$ & $\mathrm{Cl}$ & $\mathrm{Cr}_{2} \mathrm{O}_{3}$ & $\mathrm{P}_{2} \mathrm{O}_{5}$ & & \\
\hline \multirow{3}{*}{ 4B } & \multirow{25}{*}{ C } & \multirow{3}{*}{$7 / 4 / 07$} & \multirow{3}{*}{0.00} & \multirow{3}{*}{0.01} & \multirow{3}{*}{0.63} & \multirow{3}{*}{0.00} & \multirow{3}{*}{0.19} & S10-D-83A & $\mathrm{NO}$ \\
\hline & & & & & & & & S10-D-83B & $\mathrm{NO}$ \\
\hline & & & & & & & & S10-D-83C & $\mathrm{NO}$ \\
\hline \multirow{4}{*}{$4 \mathrm{C}$} & & $7 / 5 / 07$ & \multirow{4}{*}{0.70} & \multirow{4}{*}{0.01} & \multirow{4}{*}{0.62} & \multirow{4}{*}{0.53} & \multirow{4}{*}{0.18} & S10-D-83D & $\mathrm{NO}$ \\
\hline & & \multirow{18}{*}{ 7/6/07 } & & & & & & S10-D-101A & NO \\
\hline & & & & & & & & S10-D-101B & NO \\
\hline & & & & & & & & S10-D-101C & NO \\
\hline \multirow{15}{*}{ 4D } & & & \multirow{15}{*}{0.90} & & & & & S10-D-110A & YES \\
\hline & & & & & & & & S10-D-110B & YES \\
\hline & & & & & & & & S10-D-110C & YES \\
\hline & & & & & & & & S10-D-110D & TRACE \\
\hline & & & & & & & & S10-D-110E & YES \\
\hline & & & & & & & & S10-D-110F & YES \\
\hline & & & & & & & & S10-D-110G & TRACE \\
\hline & & & & 0.01 & 0.61 & 0.53 & 0.18 & S10-D-110H & TRACE \\
\hline & & & & & & & & S10-D-110I & YES \\
\hline & & & & & & & & S10-D-111A & TRACE \\
\hline & & & & & & & & S10-D-111B & YES \\
\hline & & & & & & & & S10-D-111C & YES \\
\hline & & & & & & & & S10-D-111D & NO \\
\hline & & & & & & & & S10-D-111E & NO \\
\hline & & & & & & & & S10-D-111F & TRACE \\
\hline & & & & & & & & S10-D-117A & $\mathrm{NO}$ \\
\hline $4 \mathrm{E}$ & & 7/7/07 & 0.00 & 0.01 & 0.63 & 0.00 & 0.19 & S10-D-117B & NO \\
\hline & & & & & & & & S10-D-117C & NO \\
\hline & & & & & & & & S10-D-117D & $\mathrm{NO}$ \\
\hline & & 7/9/07 & & & & & & S10-D-117E & NO \\
\hline & & & & & & & & S10-D-117F & $\mathrm{NO}$ \\
\hline $5 \mathrm{~A}$ & & & 0.70 & 0.17 & 0.33 & 0.50 & 0.29 & S10-D-139A & NO \\
\hline & & $7 / 10 / 07$ & & & & & & S10-D-139B & NO \\
\hline & & & & & & & & S10-D-139B & $\mathrm{NO}$ \\
\hline & & & & & & & & S10-D-148A & $\mathrm{NO}$ \\
\hline $5 B$ & D & $7 / 11 / 07$ & 0.90 & 0.17 & 0.33 & 0.50 & 0.29 & S10-D-148B & $\mathrm{NO}$ \\
\hline & & & & & & & & S10-D-148C & $\mathrm{NO}$ \\
\hline & & & & & & & & T10-D-12A & $\mathrm{NO}$ \\
\hline & & & & & & & & T10-D-12B & $\mathrm{NO}$ \\
\hline & & & & & & & & T10-D-12C & $\mathrm{NO}$ \\
\hline $5 \mathrm{C}$ & & 7/17/07 & 1.10 & 0.17 & 0.33 & 0.50 & 0.28 & T10-D-16A & NO \\
\hline & & & & & & & & T10-D-16B & $\mathrm{NO}$ \\
\hline & & & & & & & & T10-D-16C & NO \\
\hline
\end{tabular}


Table 4.5. Listing of Dip Samples and Presence of Sulfate Layer During DM10 Melter Tests (continued).

\begin{tabular}{|c|c|c|c|c|c|c|c|c|c|}
\hline \multirow{2}{*}{ Test } & \multirow{2}{*}{ Region } & \multirow{2}{*}{$\begin{array}{c}\text { Sampling } \\
\text { Date }\end{array}$} & \multicolumn{5}{|c|}{ Target (wt\%) } & \multirow{2}{*}{ Sample Name } & \multirow{2}{*}{$\begin{array}{c}\text { Secondary Phase } \\
\text { Observed }\end{array}$} \\
\hline & & & $\mathrm{SO}_{3}$ & $\mathrm{~F}$ & $\mathrm{Cl}$ & $\mathrm{Cr}_{2} \mathrm{O}_{3}$ & $\mathrm{P}_{2} \mathrm{O}_{5}$ & & \\
\hline \multirow{15}{*}{$5 D$} & \multirow{15}{*}{ D } & \multirow{15}{*}{$7 / 18 / 07$} & \multirow{15}{*}{1.30} & \multirow{15}{*}{0.17} & \multirow{15}{*}{0.33} & \multirow{15}{*}{0.50} & \multirow{15}{*}{0.28} & T10-D-23A & YES \\
\hline & & & & & & & & T10-D-23B & YES \\
\hline & & & & & & & & T10-D-23C & YES \\
\hline & & & & & & & & T10-D-24A & YES \\
\hline & & & & & & & & T10-D-24B & TRACE \\
\hline & & & & & & & & T10-D-24C & YES \\
\hline & & & & & & & & T10-D-24D & YES \\
\hline & & & & & & & & T10-D-24E & NO \\
\hline & & & & & & & & T10-D-24F & YES \\
\hline & & & & & & & & T10-D-24G & YES \\
\hline & & & & & & & & T10-D-24H & NO \\
\hline & & & & & & & & T10-D-24I & NO \\
\hline & & & & & & & & T10-D-25A & TRACE \\
\hline & & & & & & & & T10-D-25B & NO \\
\hline & & & & & & & & T10-D-25C & NO \\
\hline
\end{tabular}


Table 4.6. Results of PCT Leaching Procedure (ASTM C1285, 7-days at $90^{\circ} \mathrm{C}$, Stainless Steel Vessel; $\mathrm{S} / \mathrm{V}=2000 \mathrm{~m}^{-1}$ ) for $\mathrm{Crucible}^{-} \mathrm{Glass}$ and Corresponding Melter Glass Samples that Contain the Maximum Sulfur Content Without Formation of Secondary Phases During DM10 ORP LAW Tests.

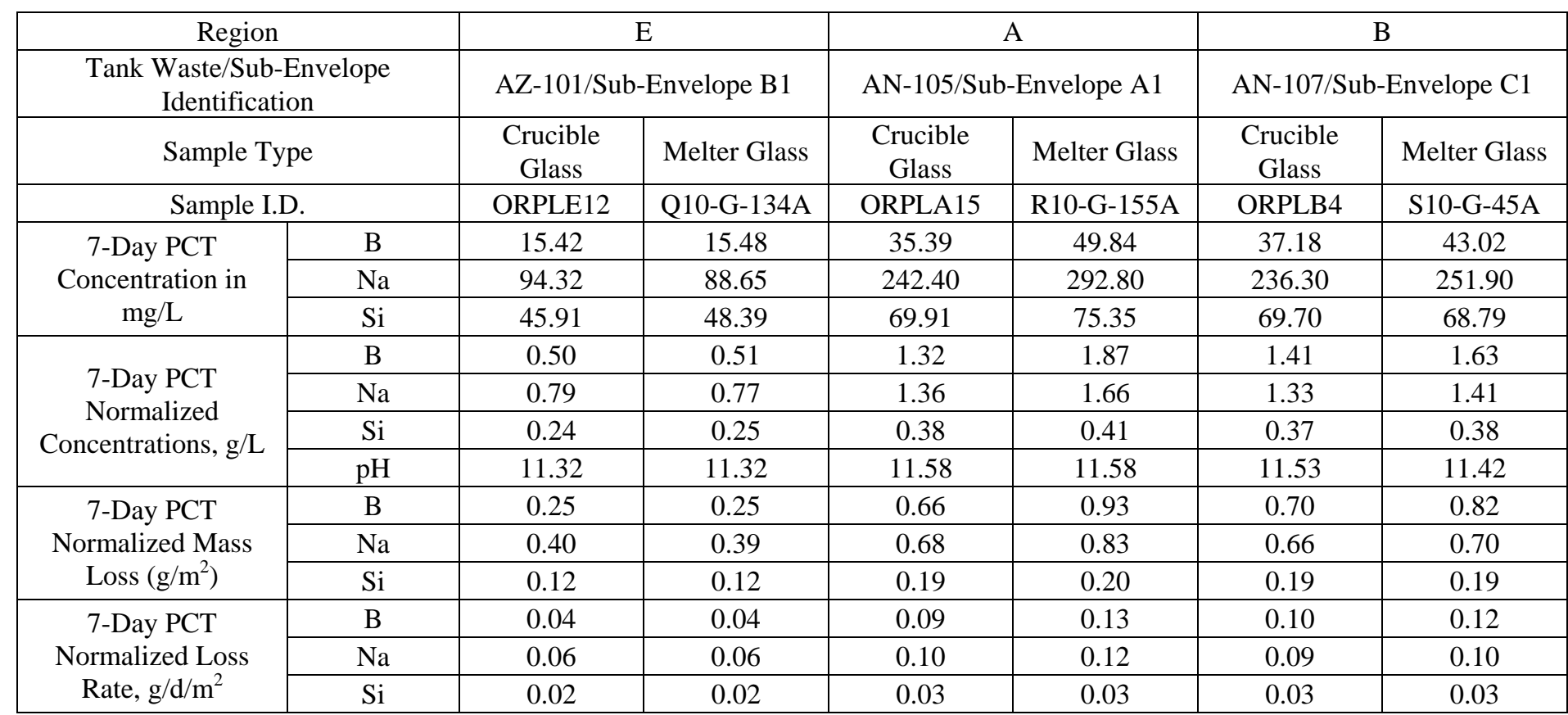


Table 4.6. Results from PCT Leaching Procedure (ASTM C1285, 7-days at $90^{\circ} \mathrm{C}$, Stainless Steel Vessel; S/V=2000m ${ }^{-1}$ ) for $\mathrm{Crucible}^{-}$Glass and Corresponding Melter Glass Samples that Contain the Maximum Sulfur Content Without Formation of Secondary Phases During DM10 ORP LAW Tests (continued).

\begin{tabular}{|c|c|c|c|c|c|c|c|}
\hline Regio & & & & & & \multirow{4}{*}{ ANL-LRM-2 } & \multirow{4}{*}{$\begin{array}{c}\text { WTP } \\
\text { Contract } \\
\text { Limit }\end{array}$} \\
\hline $\begin{array}{r}\text { Tank Waste/Sul } \\
\text { Identifica }\end{array}$ & ope & \multicolumn{2}{|c|}{ AN-104/Sub-Envelope A3 } & \multicolumn{2}{|c|}{ AN-102/Sub-Envelope C2 } & & \\
\hline \multicolumn{2}{|c|}{ Sample Type } & $\begin{array}{l}\text { Crucible } \\
\text { Glass }\end{array}$ & Melter Glass & $\begin{array}{c}\text { Crucible } \\
\text { Glass }\end{array}$ & Melter Glass & & \\
\hline \multicolumn{2}{|c|}{ Sample I.D. } & ORPLC5 & S10-G-101B & ORPLD1 & T10-G-16A & & \\
\hline \multirow{3}{*}{$\begin{array}{c}\text { 7-Day PCT } \\
\text { Concentration in } \\
\mathrm{mg} / \mathrm{L}\end{array}$} & B & 44.97 & 35.64 & 49.32 & 25.66 & 29.08 & - \\
\hline & $\mathrm{Na}$ & 260.50 & 201.40 & 223.60 & 106.30 & 165.70 & - \\
\hline & $\mathrm{Si}$ & 67.71 & 61.94 & 53.61 & 44.04 & 81.61 & - \\
\hline \multirow{4}{*}{$\begin{array}{c}\text { 7-Day PCT } \\
\text { Normalized } \\
\text { Concentrations, g/L }\end{array}$} & B & 1.70 & 1.35 & 1.32 & 0.69 & 1.17 & - \\
\hline & $\mathrm{Na}$ & 1.49 & 1.21 & 1.44 & 0.79 & 1.12 & - \\
\hline & $\mathrm{Si}$ & 0.36 & 0.32 & 0.31 & 0.23 & 0.32 & - \\
\hline & $\mathrm{pH}$ & 11.38 & 11.28 & 11.45 & 10.65 & 11.08 & - \\
\hline \multirow{3}{*}{$\begin{array}{l}\text { 7-Day PCT } \\
\text { Normalized Mass } \\
\text { Loss }\left(\mathrm{g} / \mathrm{m}^{2}\right)\end{array}$} & B & 0.85 & 0.67 & 0.66 & 0.34 & 0.59 & $<2.0$ \\
\hline & $\mathrm{Na}$ & 0.74 & 0.60 & 0.72 & 0.40 & 0.56 & $<2.0$ \\
\hline & $\mathrm{Si}$ & 0.18 & 0.16 & 0.15 & 0.12 & 0.16 & $<2.0$ \\
\hline \multirow{3}{*}{$\begin{array}{c}\text { 7-Day PCT } \\
\text { Normalized Loss } \\
\text { Rate, g/d/m² }\end{array}$} & B & 0.12 & 0.10 & 0.09 & 0.05 & 0.08 & - \\
\hline & $\mathrm{Na}$ & 0.11 & 0.09 & 0.10 & 0.06 & 0.08 & - \\
\hline & $\mathrm{Si}$ & 0.03 & 0.02 & 0.02 & 0.02 & 0.02 & - \\
\hline
\end{tabular}

- Empty data field 
Table 4.7. VHT Results (24 Day) for Crucible Glass and Corresponding Melter Glass Samples that Contain the Maximum Sulfur Content Without Formation of Secondary Phases During DM10 ORP LAW Tests.

\begin{tabular}{|c|c|c|c|c|c|c|c|}
\hline & Region & \multicolumn{2}{|c|}{$\mathbf{E}$} & \multicolumn{4}{|c|}{$\mathbf{A}$} \\
\hline Tank Waste & b-Envelope Identification & AZ-101/Su & nvelope B1 & \multicolumn{4}{|c|}{ AN-105/Sub-Envelope A1 } \\
\hline \multicolumn{2}{|c|}{ Sample Type } & Crucible Glass & Melter Glass & Crucible Glass & \multicolumn{3}{|c|}{ Melter Glass } \\
\hline \multicolumn{2}{|c|}{ Sample I.D. } & ORPLE12 & Q10-G-134A & ORPLA15 & $\begin{array}{l}\text { R10-G-91E } \\
\text { (low sulfur) }\end{array}$ & $\begin{array}{c}\text { R10-G-155A } \\
\text { (Heavily foamed) }\end{array}$ & $\begin{array}{c}\text { R10-G-155A } \\
\text { Re-melted }\end{array}$ \\
\hline \multirow{3}{*}{$\begin{array}{c}\text { Based on } \\
\text { Layer } \\
\text { Thickness }\end{array}$} & Alteration depth $(\mu \mathrm{m})$ & 375 & 350 & 275 & 325 & \multirow{6}{*}{$\begin{array}{l}\text { Coupon fully } \\
\text { reacted }\end{array}$} & 395 \\
\hline & Rate $\left(\mathrm{g} / \mathrm{m}^{2} / \mathrm{d}\right)$ & 41 & 39 & 30 & 36 & & 44 \\
\hline & $\begin{array}{c}\begin{array}{c}\text { Compared to limit of } 50 \\
\mathrm{~g} / \mathrm{m}^{2} / \mathrm{d}\end{array} \\
\end{array}$ & $82 \%$ & $78 \%$ & $60 \%$ & $72 \%$ & & $88 \%$ \\
\hline \multirow{3}{*}{$\begin{array}{c}\text { Based on } \\
\text { Remaining } \\
\text { Glass }\end{array}$} & Alteration depth $(\mu \mathrm{m})$ & 277 & 301 & 230 & 554 & & 751 \\
\hline & Rate $\left(\mathrm{g} / \mathrm{m}^{2} / \mathrm{d}\right)$ & 31 & 33 & 25 & 61 & & 83 \\
\hline & $\begin{array}{c}\begin{array}{c}\text { Compared to limit of } 50 \\
\mathrm{~g} / \mathrm{m}^{2} / \mathbf{d}\end{array} \\
\end{array}$ & $62 \%$ & $66 \%$ & $50 \%$ & $122 \%$ & & $166 \%$ \\
\hline
\end{tabular}

Rates calculated with an average density of $2.65 \mathrm{~g} / \mathrm{cm}^{3}$

NC - Not calculated 
Table 4.7. VHT Results (24 Day) for Crucible Glass and Corresponding Melter Glass Samples that Contain the Maximum Sulfur Content Without Formation of Secondary Phases During DM10 ORP LAW Tests (continued).

\begin{tabular}{|c|c|c|c|c|c|c|c|c|c|}
\hline \multicolumn{2}{|r|}{ Region } & \multicolumn{3}{|c|}{ B } & \multicolumn{3}{|c|}{$\mathbf{C}$} & \multicolumn{2}{|c|}{ D } \\
\hline \multicolumn{2}{|c|}{$\begin{array}{c}\text { Tank Waste/Sub-Envelope } \\
\text { Identification }\end{array}$} & \multicolumn{3}{|c|}{ AN-107/Sub-Envelope C1 } & \multicolumn{3}{|c|}{ AN-104/Sub-Envelope A3 } & \multicolumn{2}{|c|}{ AN-102/Sub-Envelope C2 } \\
\hline \multicolumn{2}{|c|}{ Sample Type } & Crucible Glass & \multicolumn{2}{|c|}{ Melter Glass } & Crucible Glass & \multicolumn{2}{|c|}{ Melter Glass } & Crucible Glass & Melter Glass \\
\hline \multicolumn{2}{|c|}{ Sample I.D. } & ORPLB4 & S10-G-45A & $\begin{array}{l}\text { S10-G-45A } \\
\text { Re-melted }\end{array}$ & ORPLC5 & S10-G-101B & $\begin{array}{l}\text { S10-G-101B } \\
\text { Re-melted }\end{array}$ & ORPLD1 & T10-G-16A \\
\hline \multirow{3}{*}{$\begin{array}{c}\text { Based on } \\
\text { Direct } \\
\text { Layer }\end{array}$} & $\begin{array}{l}\text { Alteration } \\
\text { depth }(\mu \mathrm{m})\end{array}$ & 450 & 417 & 401 & 318 & 300 & 232 & 175 & 163 \\
\hline & Rate $\left(g / \mathrm{m}^{2} / \mathrm{d}\right)$ & 50 & 46 & 44 & 35 & 33 & 26 & 19 & 18 \\
\hline & $\begin{array}{c}\text { Compared to } \\
\text { limit of } 50 \\
\text { g/m } / \mathbf{m}^{2} / \mathbf{d} \\
\end{array}$ & $100 \%$ & $92 \%$ & $88 \%$ & $70 \%$ & $66 \%$ & $52 \%$ & $38 \%$ & $36 \%$ \\
\hline \multirow{3}{*}{$\begin{array}{c}\text { Based on } \\
\text { Remaining } \\
\text { Glass }\end{array}$} & $\begin{array}{l}\text { Alteration } \\
\text { depth }(\mu \mathrm{m})\end{array}$ & 369 & 481 & 604 & 362 & 292 & 240 & 99 & 99 \\
\hline & Rate $\left(\mathrm{g} / \mathrm{m}^{2} / \mathrm{d}\right)$ & 41 & 53 & 67 & 40 & 32 & 27 & 11 & 11 \\
\hline & $\begin{array}{c}\text { Compared to limit } \\
\text { of } 50 \mathrm{~g} / \mathrm{m}^{2} / \mathrm{d}\end{array}$ & $82 \%$ & $106 \%$ & $134 \%$ & $80 \%$ & $64 \%$ & $54 \%$ & $22 \%$ & $22 \%$ \\
\hline
\end{tabular}

Rates calculated with an average density of $2.65 \mathrm{~g} / \mathrm{cm} 3$ 
Table 5.1. Maximum Sodium and Sulfur Oxide Concentrations Achieved in Crucible and Melter Tests (wt\% in Glass).

\begin{tabular}{|c|c|c|c|c|c|c|}
\hline \multicolumn{2}{|c|}{$\begin{array}{r}\text { Region } \\
\end{array}$} & A & B & $\mathrm{C}$ & $\mathrm{D}$ & $\mathrm{E}$ \\
\hline \multicolumn{2}{|c|}{$\begin{array}{c}\text { Tank Waste/ } \\
\text { Sub-Envelope Identification }\end{array}$} & $\begin{array}{c}\text { AN-105/ } \\
\text { Sub- } \\
\text { Envelope A1 }\end{array}$ & $\begin{array}{c}\text { AN-107/ } \\
\text { Sub- } \\
\text { Envelope C1 }\end{array}$ & $\begin{array}{c}\text { AN-104/ } \\
\text { Sub- } \\
\text { Envelope A3 }\end{array}$ & $\begin{array}{c}\text { AN-102/ } \\
\text { Sub- } \\
\text { Envelope C2 }\end{array}$ & $\begin{array}{c}\text { AZ-101/ } \\
\text { Sub- } \\
\text { Envelope B1 }\end{array}$ \\
\hline \multirow{3}{*}{$\begin{array}{c}\text { Crucible } \\
\text { Studies }\end{array}$} & $\mathrm{Na}_{2} \mathrm{O}$ & 24.0 & 24.0 & 23.57 & 21.0 & 16.0 \\
\hline & $\mathrm{SO}_{3}$ (batching) & 0.27 & 0.52 & 0.56 & 0.70 & 1.20 \\
\hline & $\mathrm{SO}_{3}$ (bubbling) & NM & 0.70 & NM & NM & 1.55 \\
\hline \multirow{4}{*}{$\begin{array}{l}\text { Melter } \\
\text { Studies }\end{array}$} & Target Feed $\mathrm{Na}_{2} \mathrm{O}$ & 24.0 & 24.0 & 23.57 & 21.0 & 16.0 \\
\hline & Target Feed $\mathrm{SO}_{3}$ & 0.6 & 0.85 & 0.70 & 1.10 & 1.50 \\
\hline & Measured $\mathrm{Na}_{2} \mathrm{O}$ & 23.76 & 24.12 & 22.45 & 18.11 & 15.45 \\
\hline & Measured $\mathrm{SO}_{3}$ & 0.52 & 0.68 & 0.61 & 0.89 & 1.38 \\
\hline \multirow{4}{*}{$\begin{array}{l}\text { Previous } \\
\text { Melter } \\
\text { Studies }\end{array}$} & Target Feed $\mathrm{Na}_{2} \mathrm{O}$ & $23.0[6]$ & & & 20.0 [5] & $10.0[6]^{*}$ \\
\hline & Target Feed $\mathrm{SO}_{3}$ & 1.0 & & & 1.125 & 1.5 \\
\hline & Measured $\mathrm{Na}_{2} \mathrm{O}$ & 22.0 & & & 19.9 & 10.7 \\
\hline & Measured $\mathrm{SO}_{3}$ & 0.88 & & & 1.07 & 1.33 \\
\hline
\end{tabular}

* - Previous tests with LAW Sub-Envelope B2 waste. 




Figure 2.1. Sulfate solubility determined by remelting with excess $\mathrm{SO}_{3}$ for forty one new $\mathrm{ORP} \mathrm{LAW}$ crucible glasses. 


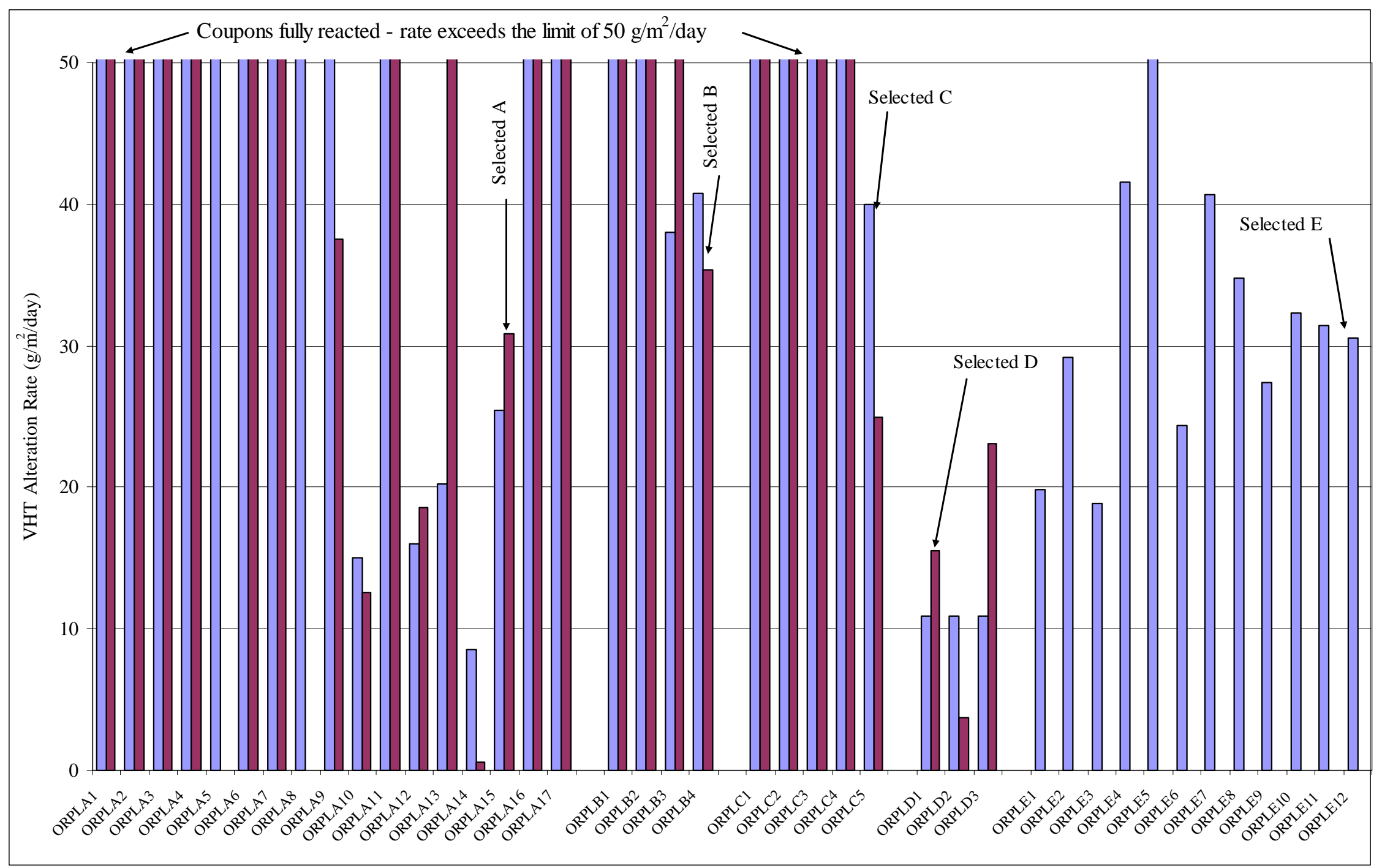

Figure 2.2. VHT results for forty one new ORP LAW crucible glasses. 


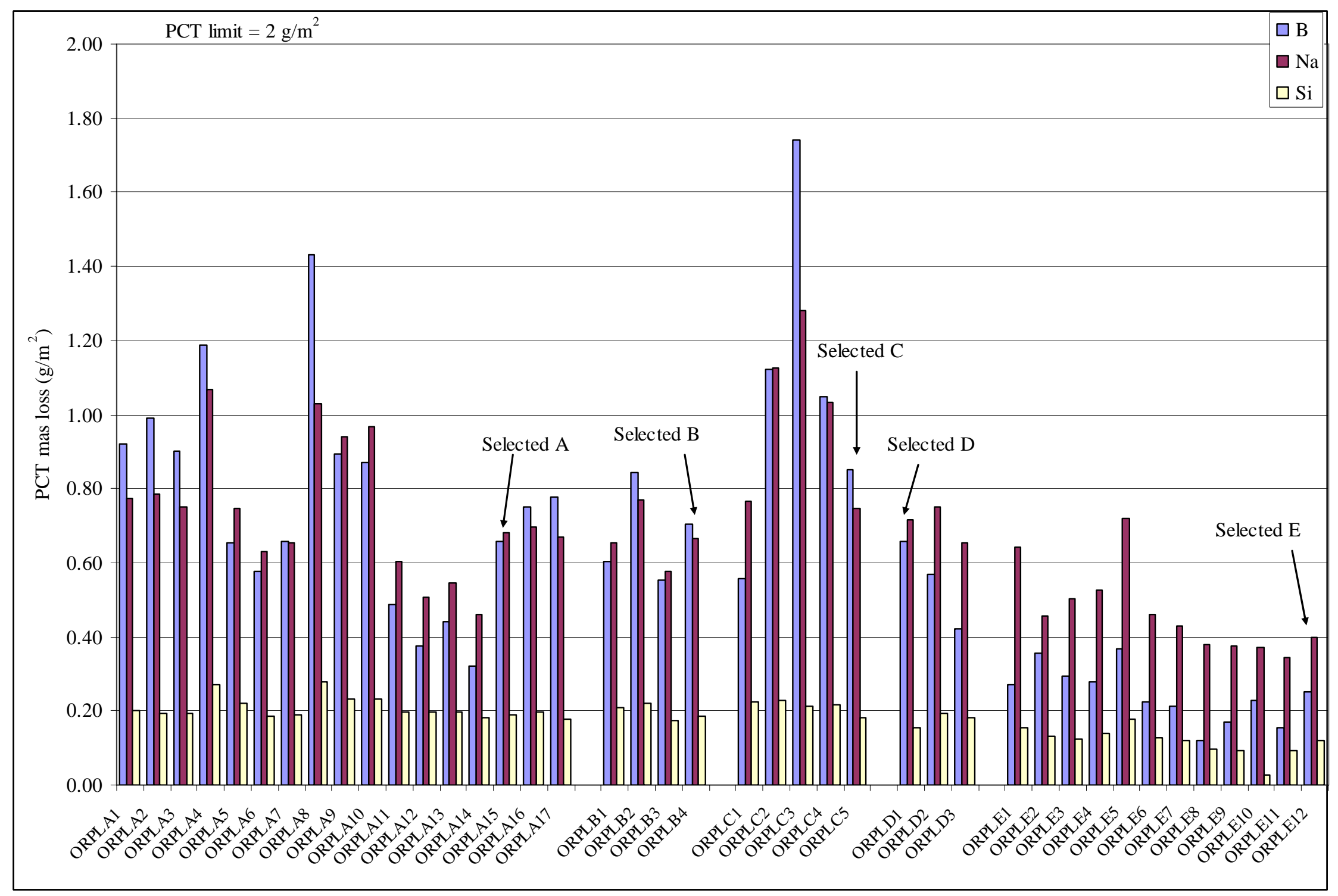

Figure 2.3. Normalized PCT releases for forty one new ORP LAW crucible glasses. 


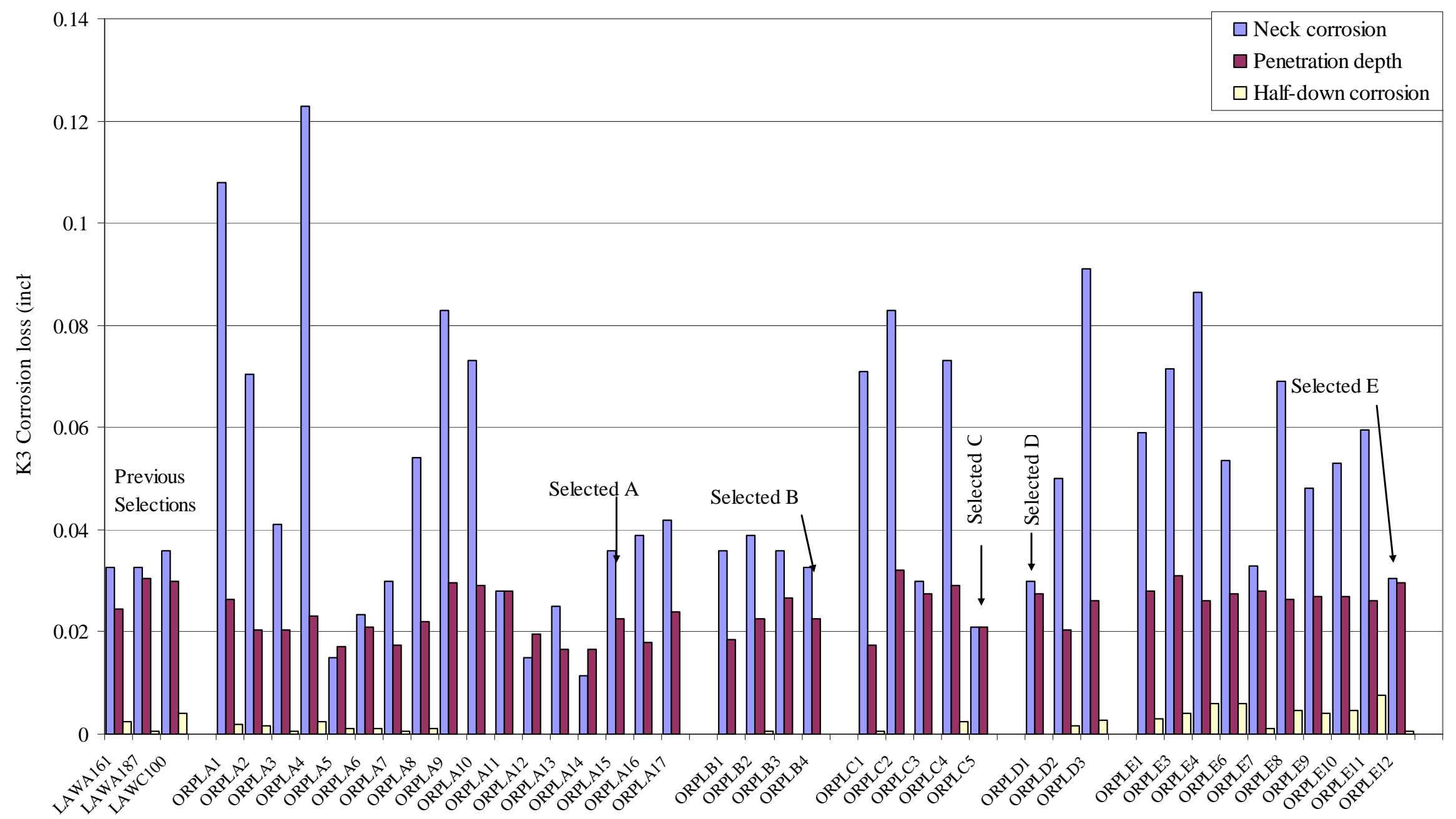

Figure 2.4. K3 Corrosion results for thirty eight new ORP LAW crucible glasses and three old LAW formulations. 


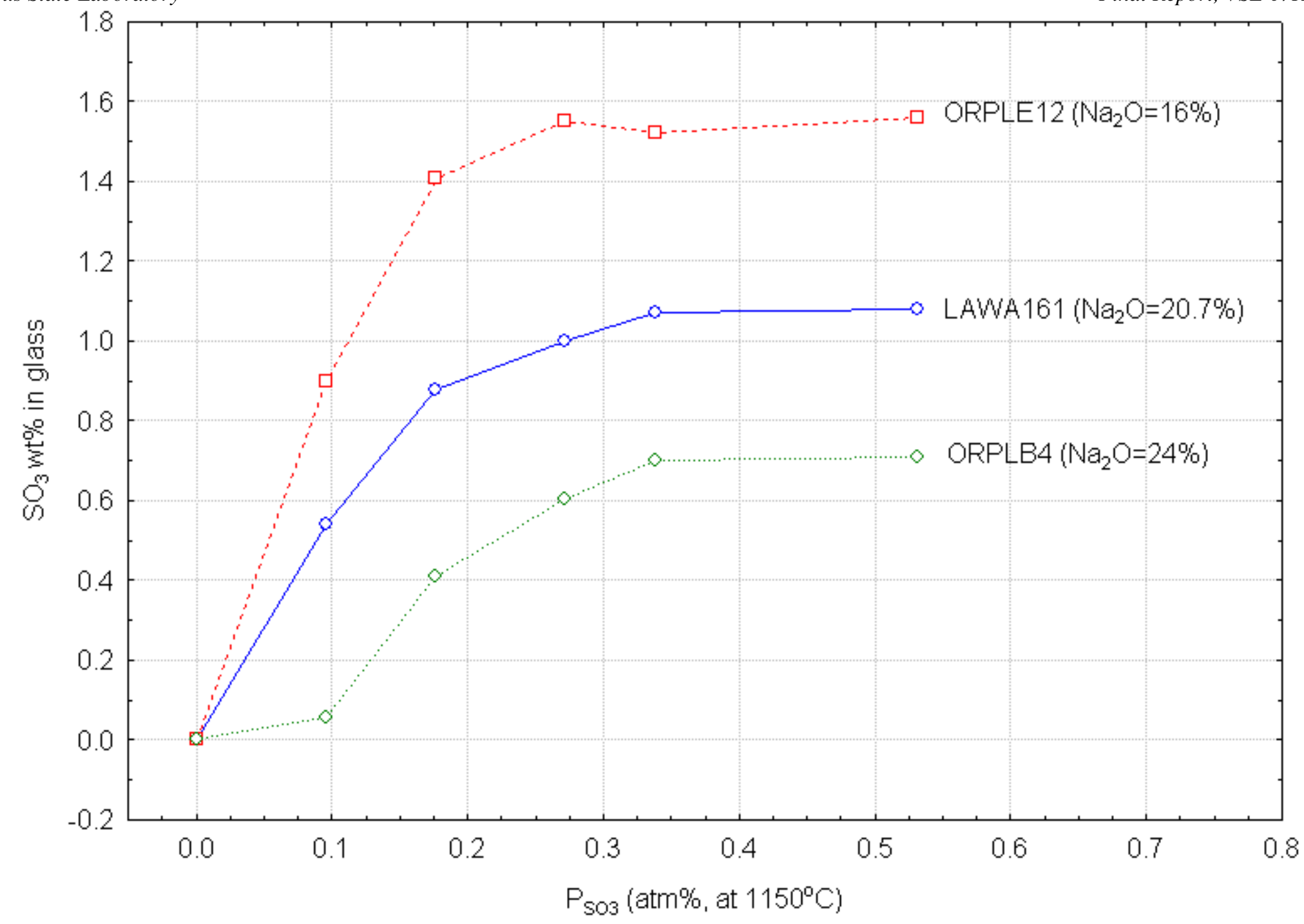

Figure 2.5. Results of $\mathrm{SO}_{2} / \mathrm{O}_{2}$ gas bubbling tests on the new ORP LAW glasses ORPLB4 and ORPLE12 and the previous ORP Envelope A glass LAWA161 at $1150^{\circ} \mathrm{C}$ showing the partial pressure of $\mathrm{SO}_{3}$ vs. the $\mathrm{SO}_{3}$ concentration in the glass melt. The horizontal portions indicate the solubility limits while the slopes at lower concentrations provide measures of the activity coefficient of $\mathrm{SO}_{3}$ in the melt. 


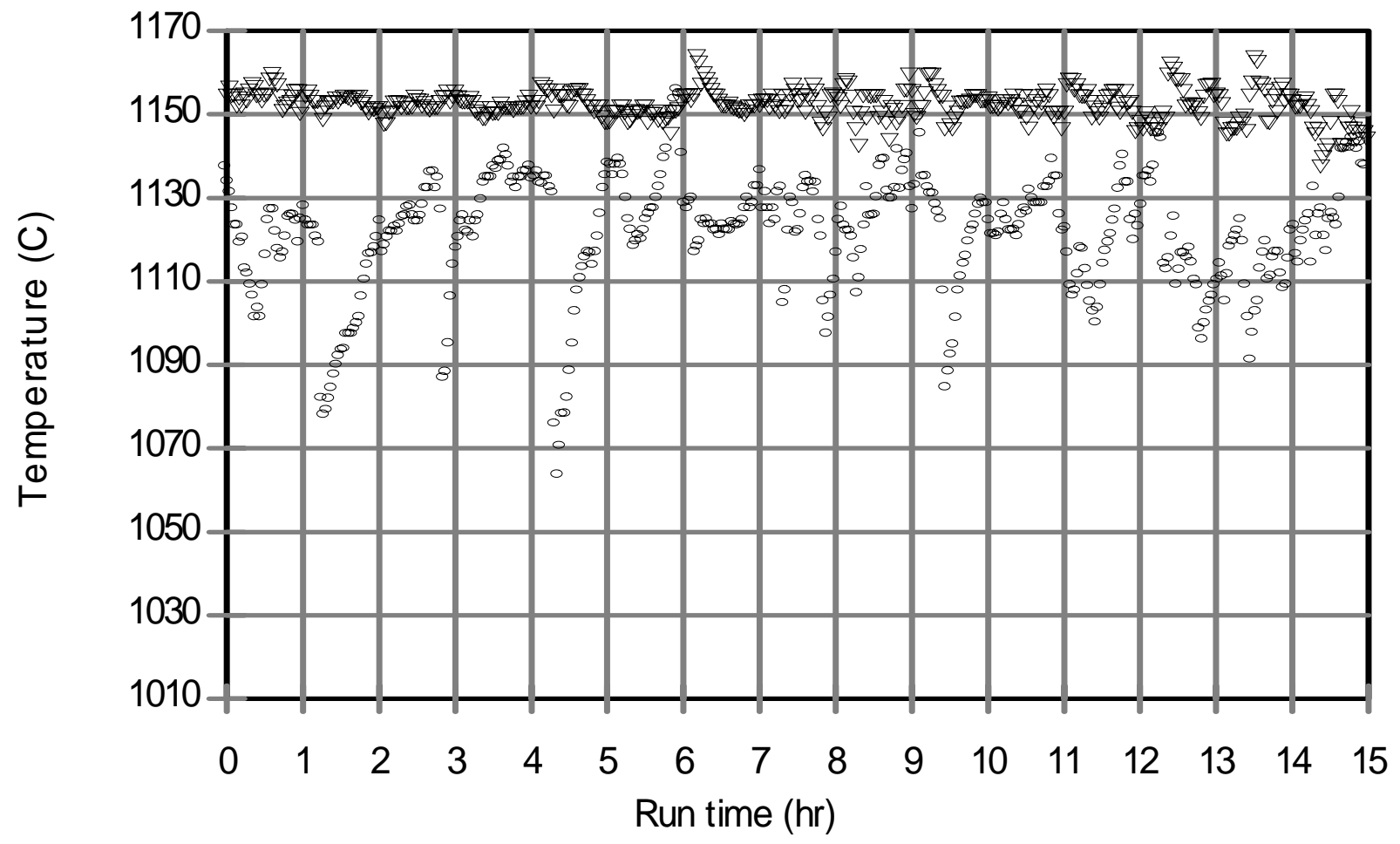

$\nabla$ Glass, 2" from floor

- Glass, 4" from floor

Figure 3.1. Representative plot of glass pool temperatures during DM10 tests. This plot is from the first test performed (Region E, Test $1 \mathrm{~A}$ ) and a portion of the idling period prior to Test $1 \mathrm{~B}$. The temperatures at 2" above the floor, which are most representative of the bilk glass temperature, closely approximate the target of $1150^{\circ} \mathrm{C}$. 


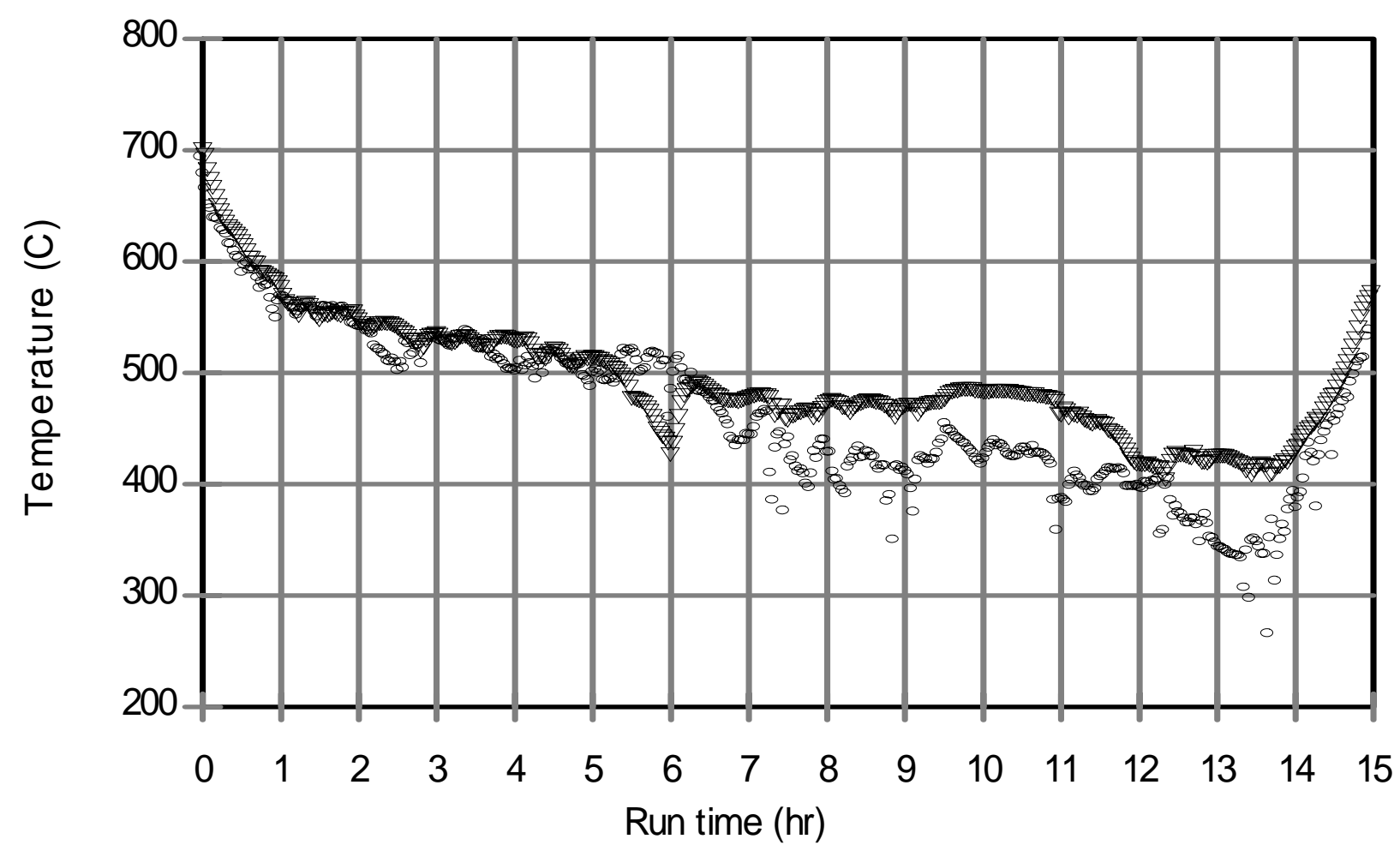

$\boldsymbol{\nabla}$ Plenum, thermowell

- Plenum, exposed

Figure 3.2. Representative plot of plenum temperatures during DM10 tests. This plot is from the first test performed (Region E, Test 1A) and a portion of the idling period prior to Test $1 B$. The temperatures fall into the 550 to $400^{\circ} \mathrm{C}$ range after about 2 hours of feeding and increase again during idling. 


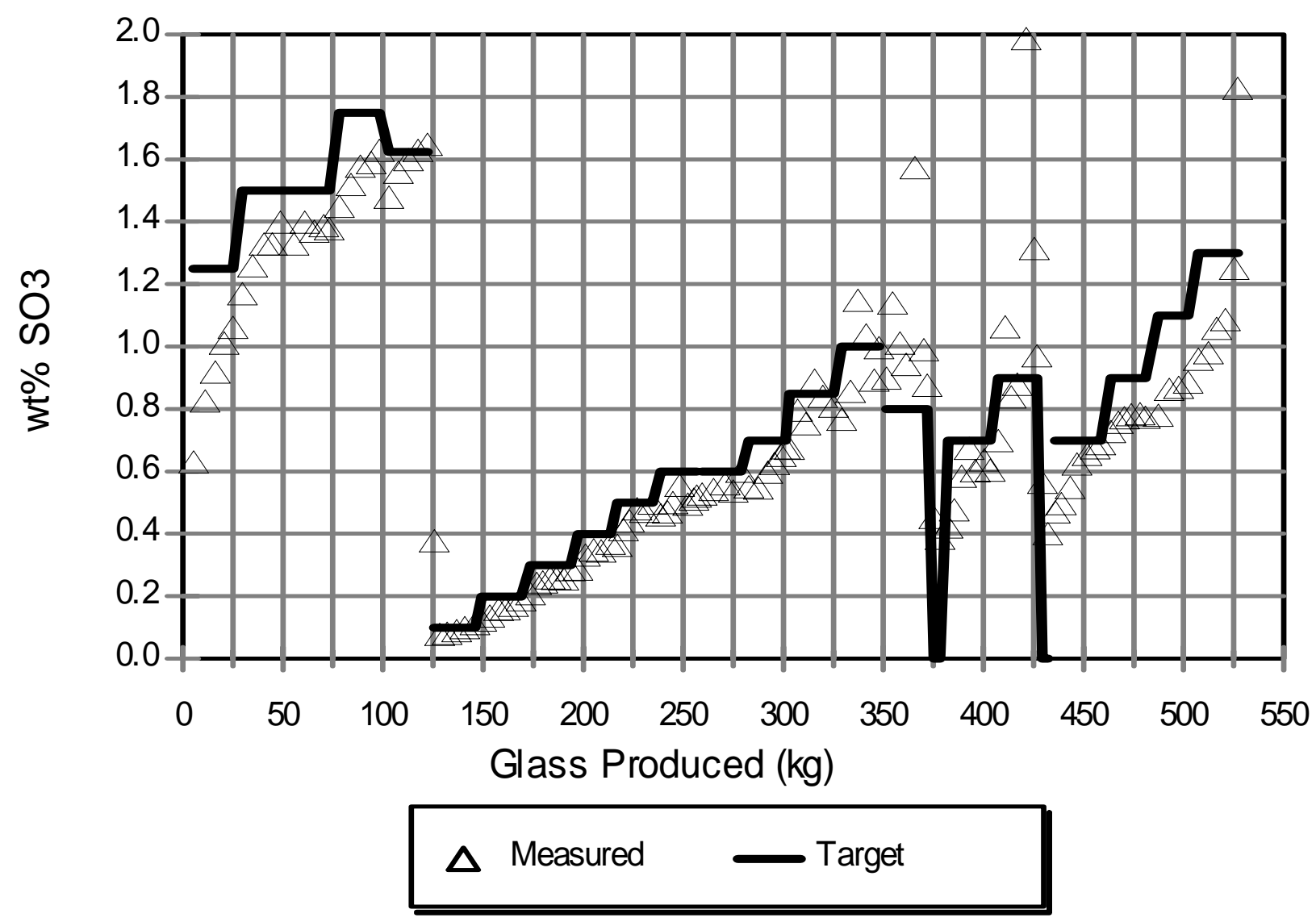

Figure 3.3. XRF analysis of sulfur in DM10 product glasses. 


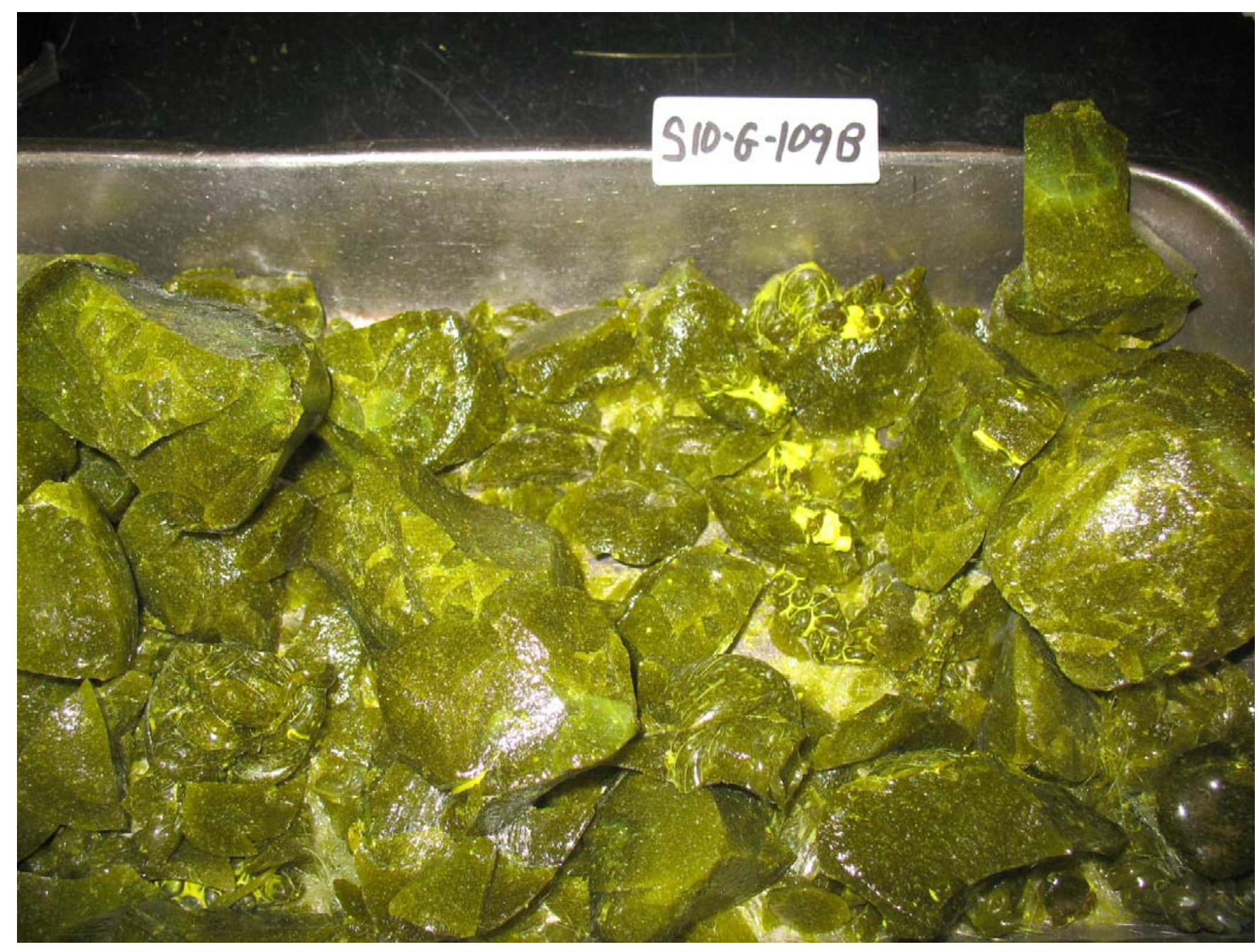

Figure 4.1. Secondary sulfur phases on discharge glass S10-G-109B from the end of Test 4D. 


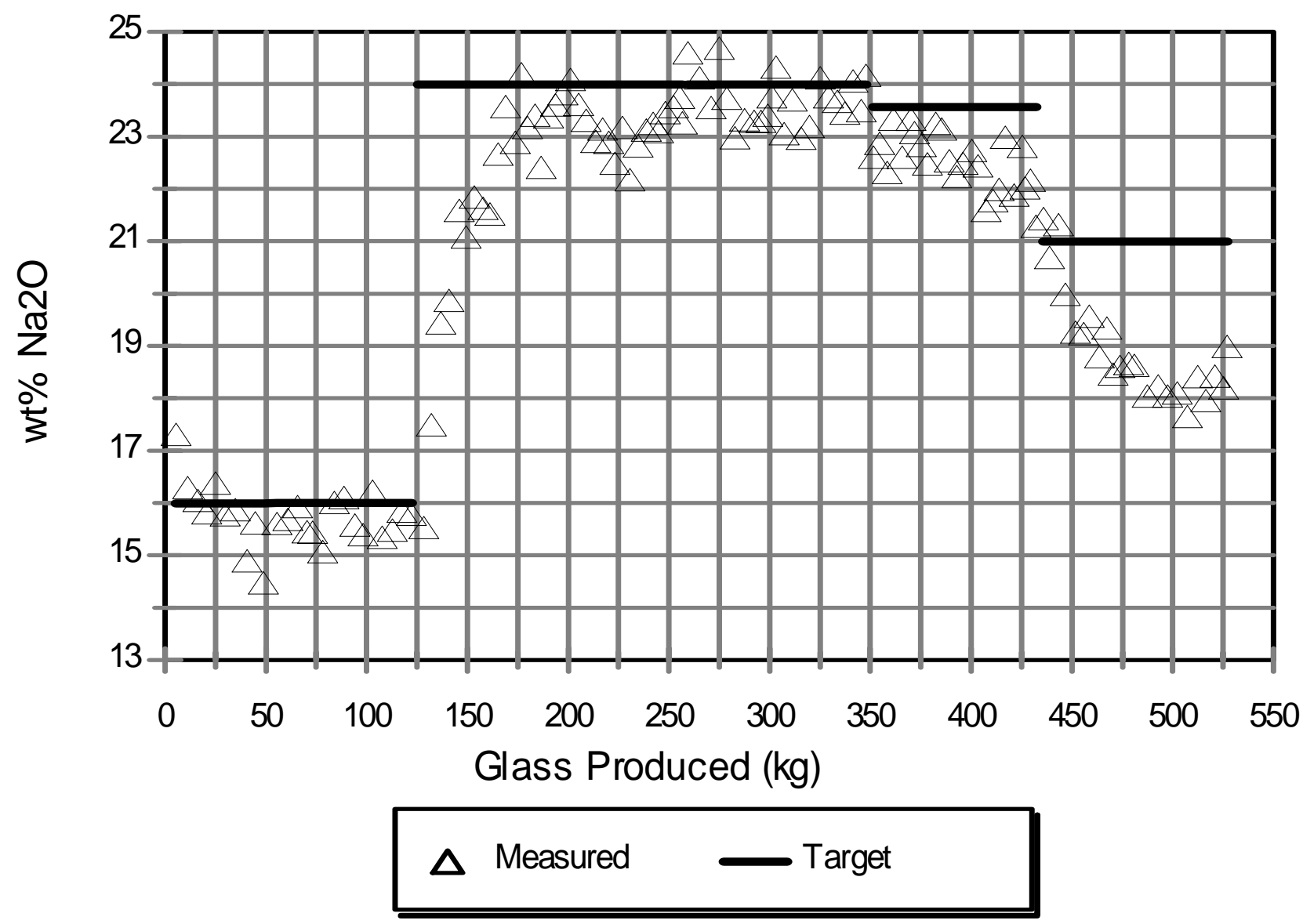

Figure 4.2. XRF analysis of sodium in DM10 product glasses. 


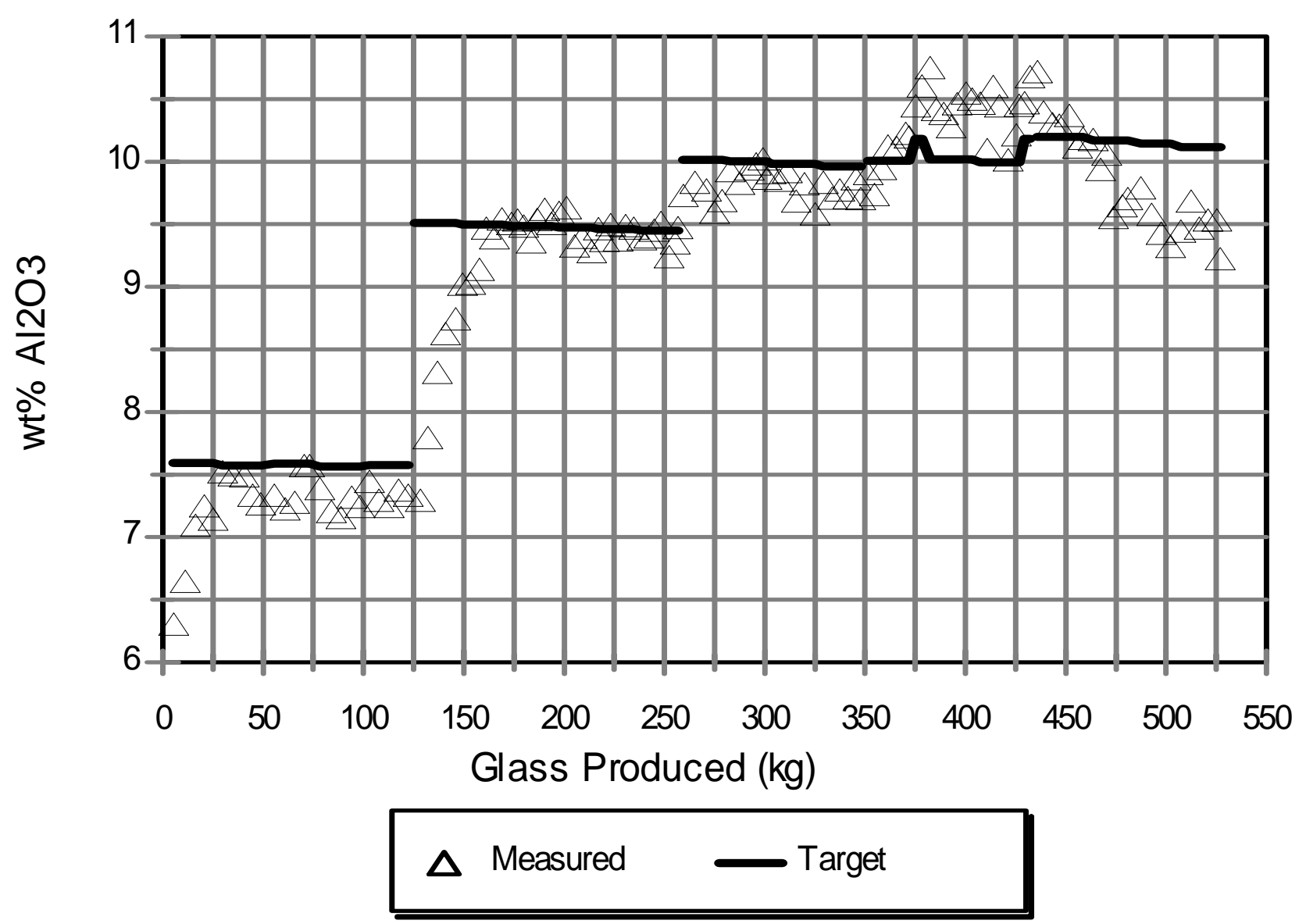

Figure 4.3. XRF analysis of aluminum in DM10 product glasses. 


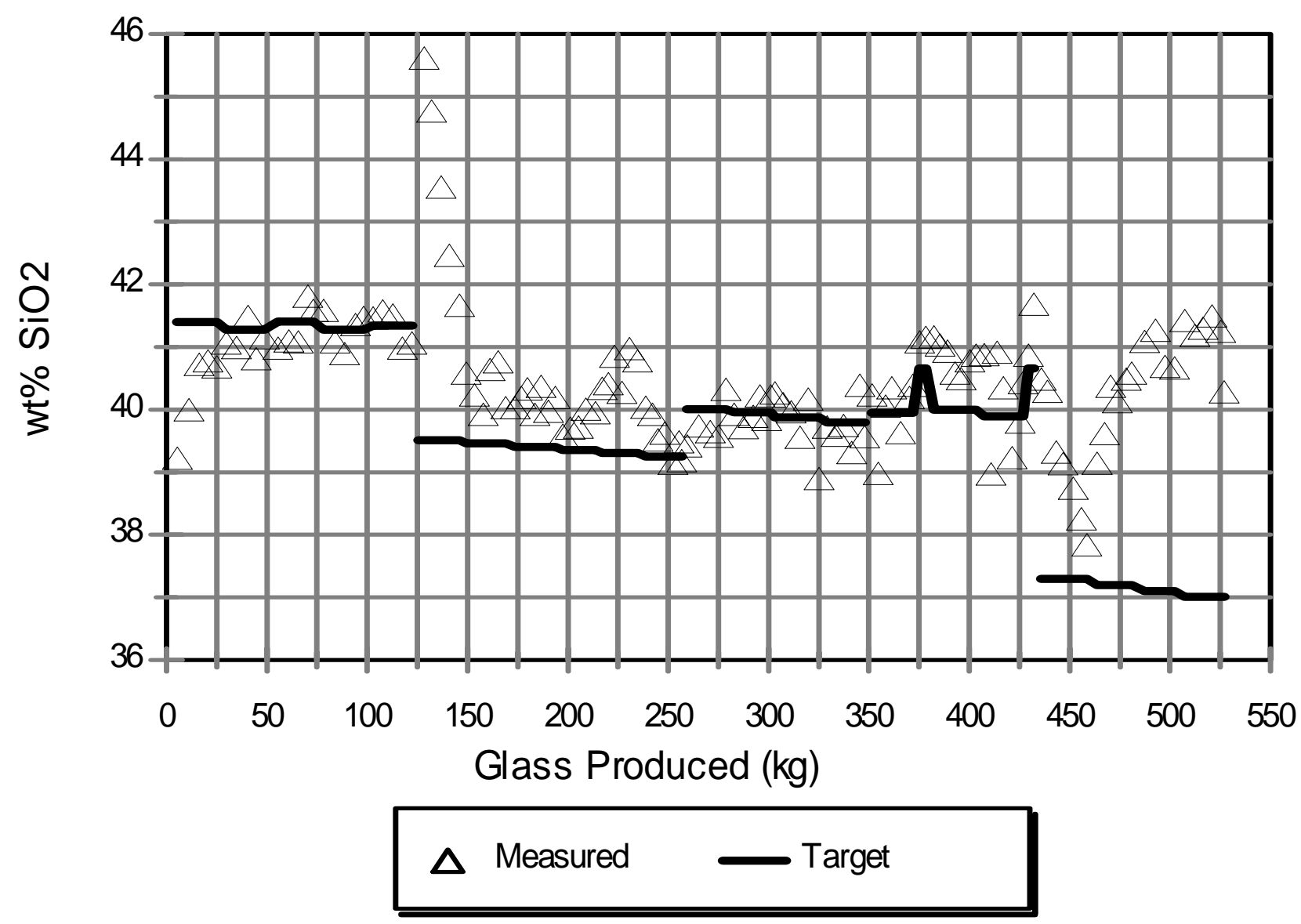

Figure 4.4. XRF analysis of silicon in DM10 product glasses. 


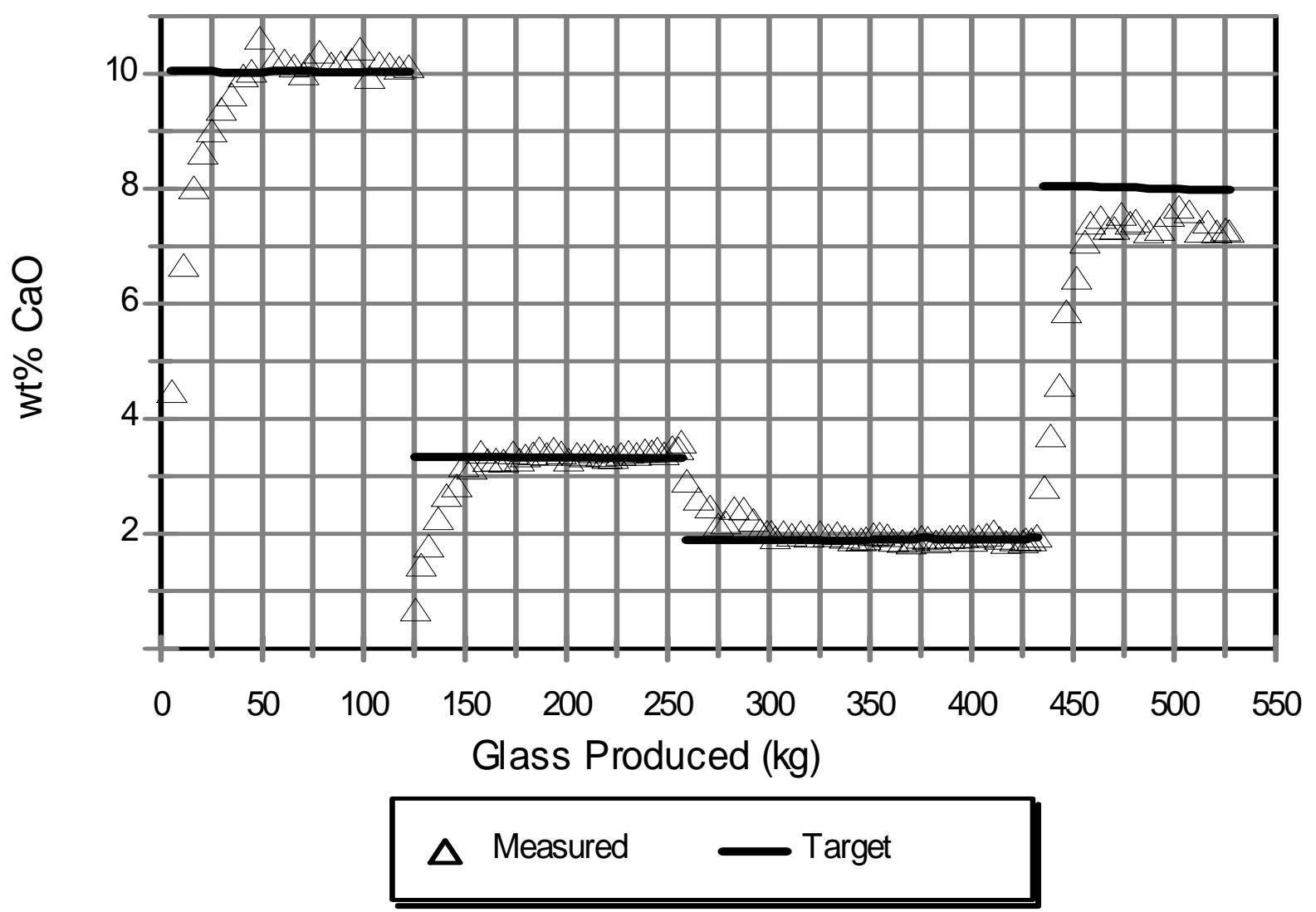

Figure 4.5. XRF analysis of calcium in DM10 product glasses. 


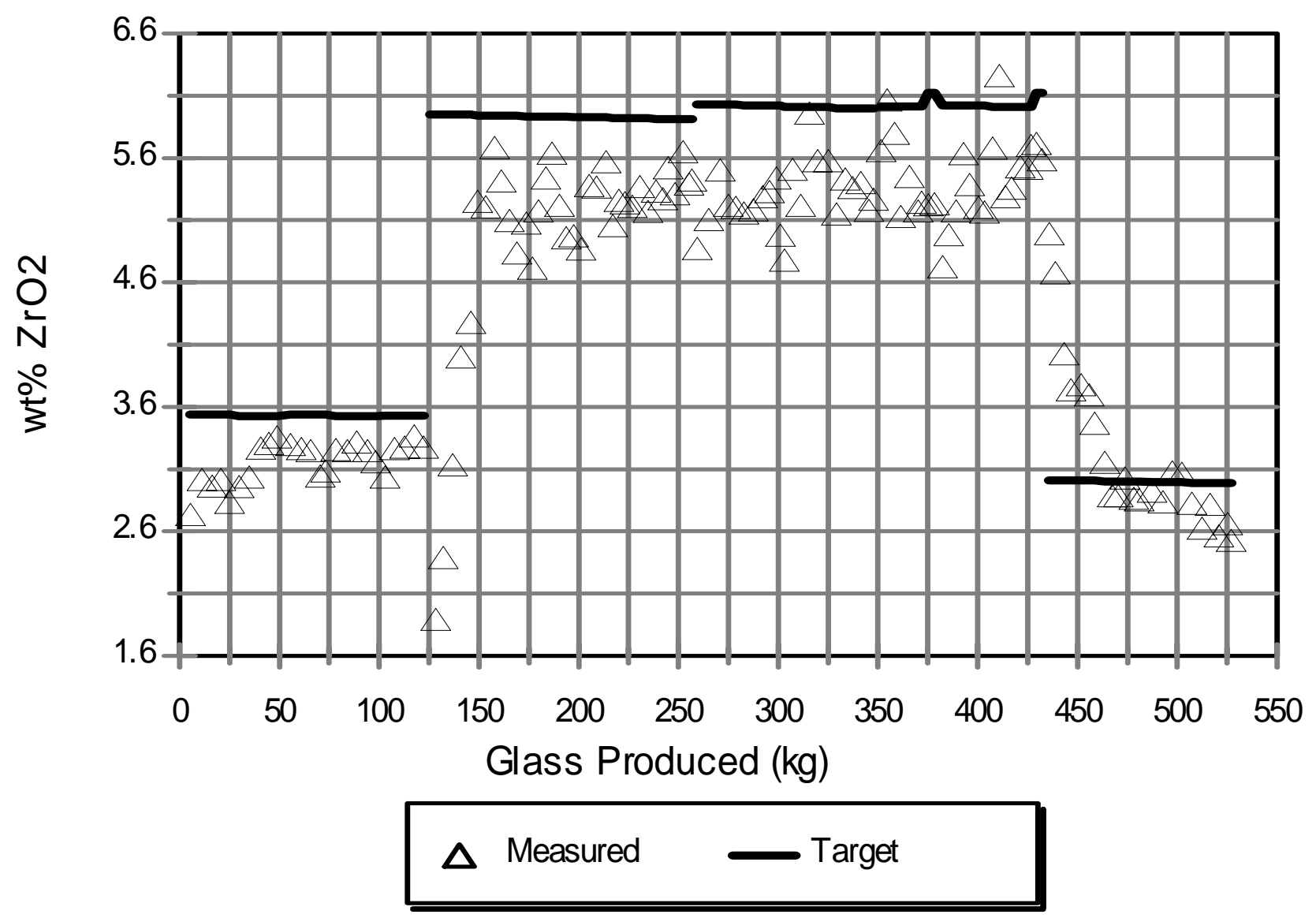

Figure 4.6. XRF analysis of zirconium in DM10 product glasses. 


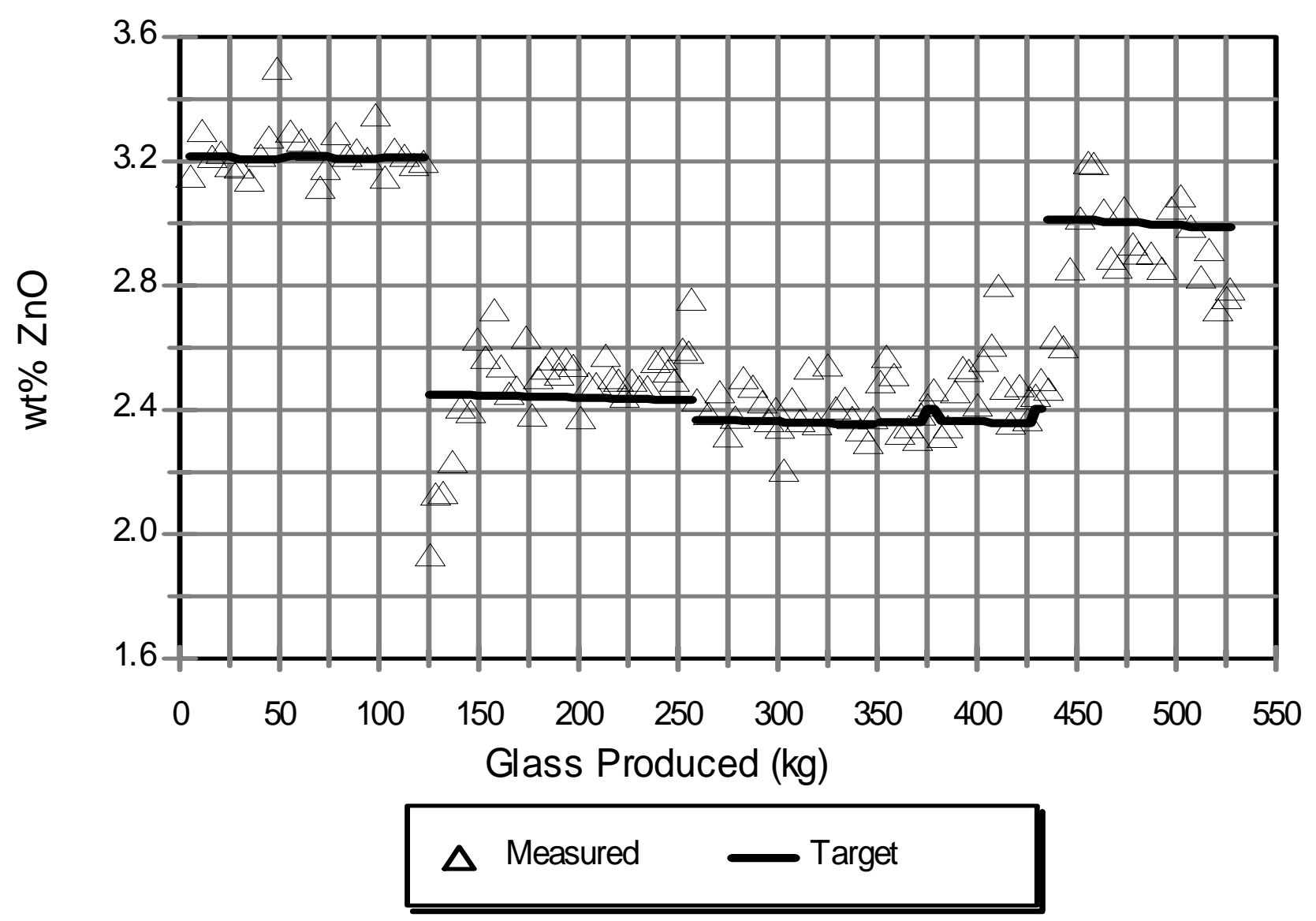

Figure 4.7. XRF analysis of zinc in DM10 product glasses. 


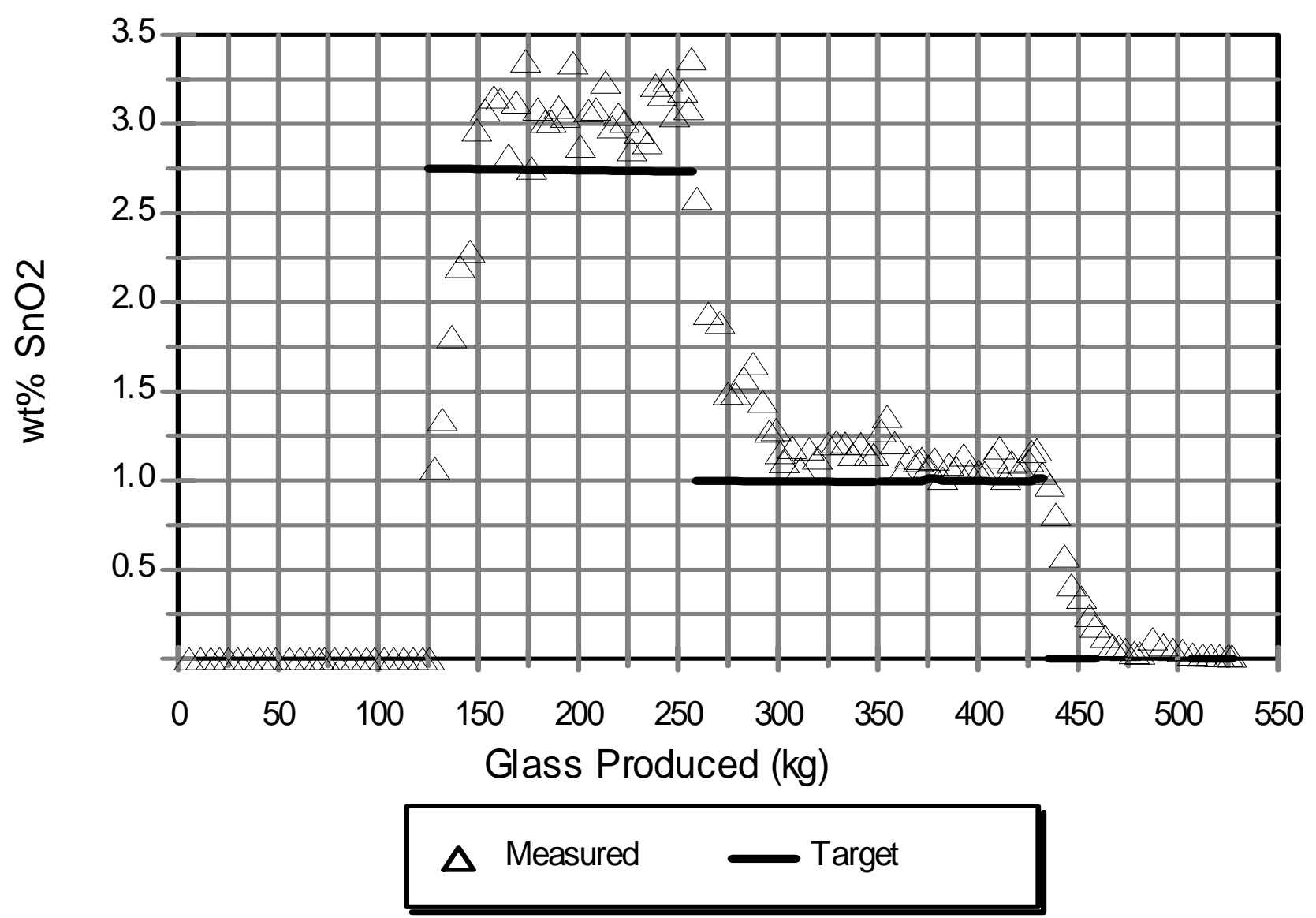

Figure 4.8. XRF analysis of tin in DM10 product glasses. 


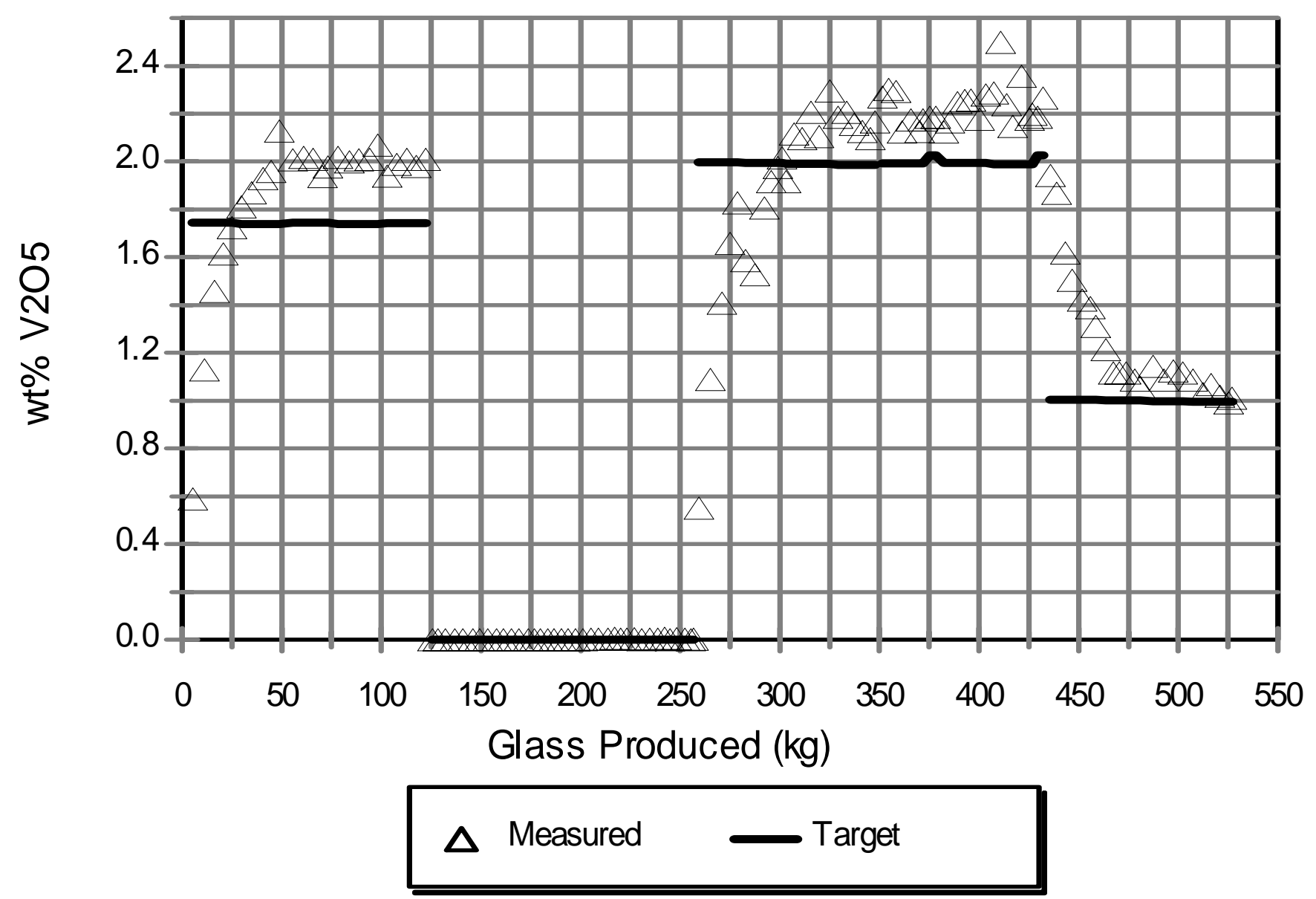

Figure 4.9. XRF analysis of vanadium in DM10 product glasses. 


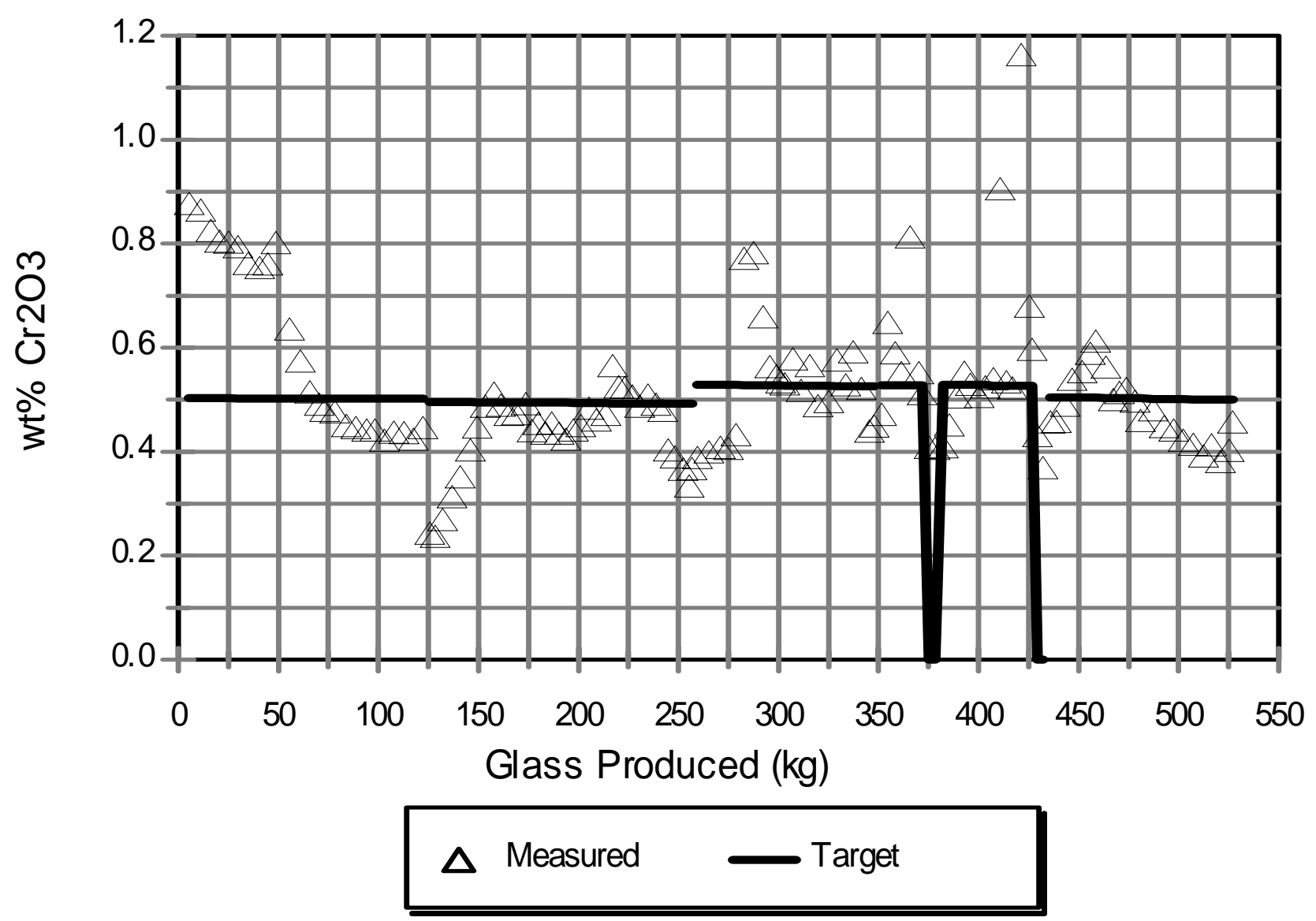

Figure 4.10. XRF analysis of chromium in DM10 product glasses. 


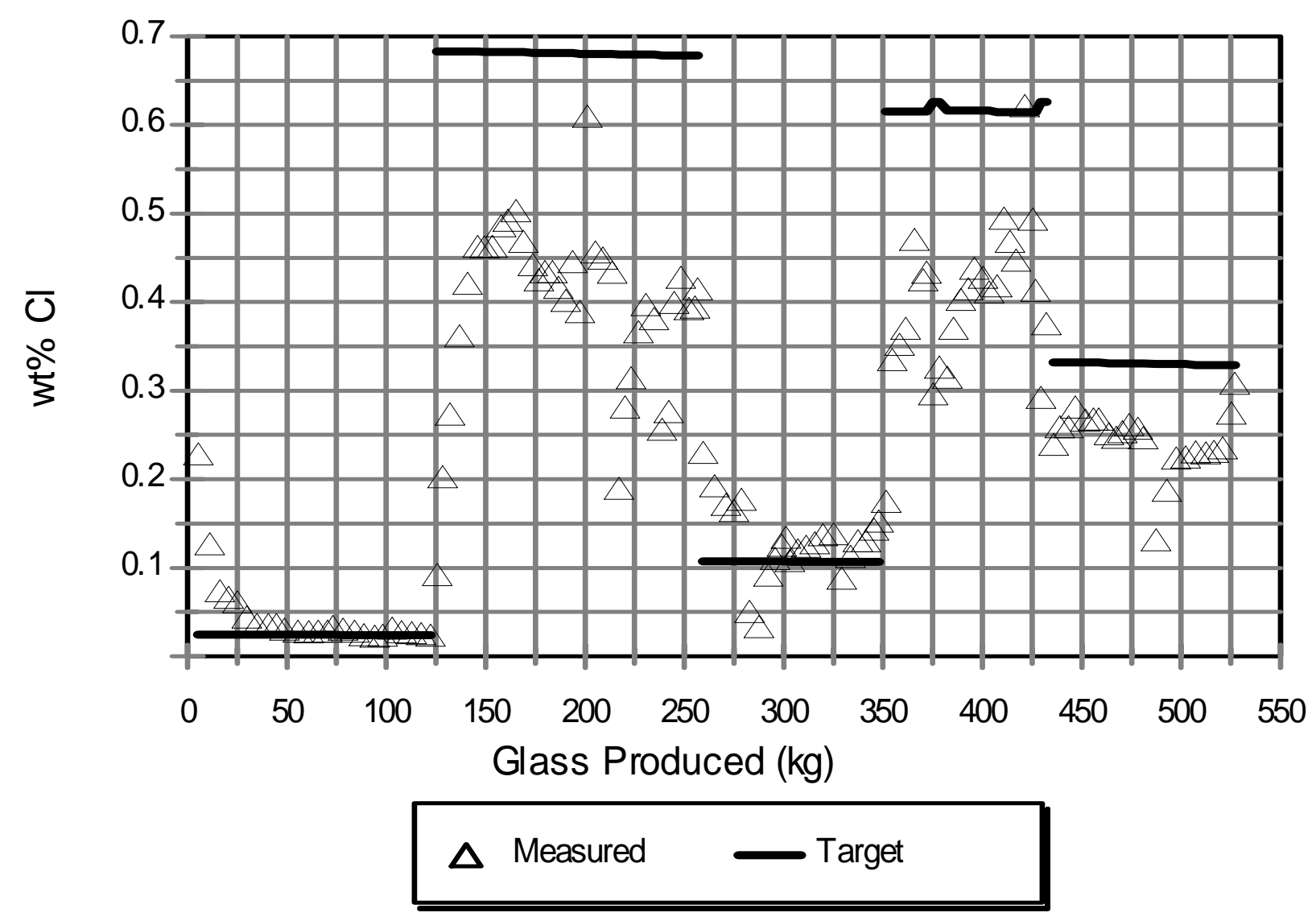

Figure 4.11. XRF analysis of chlorine in DM10 product glasses. 


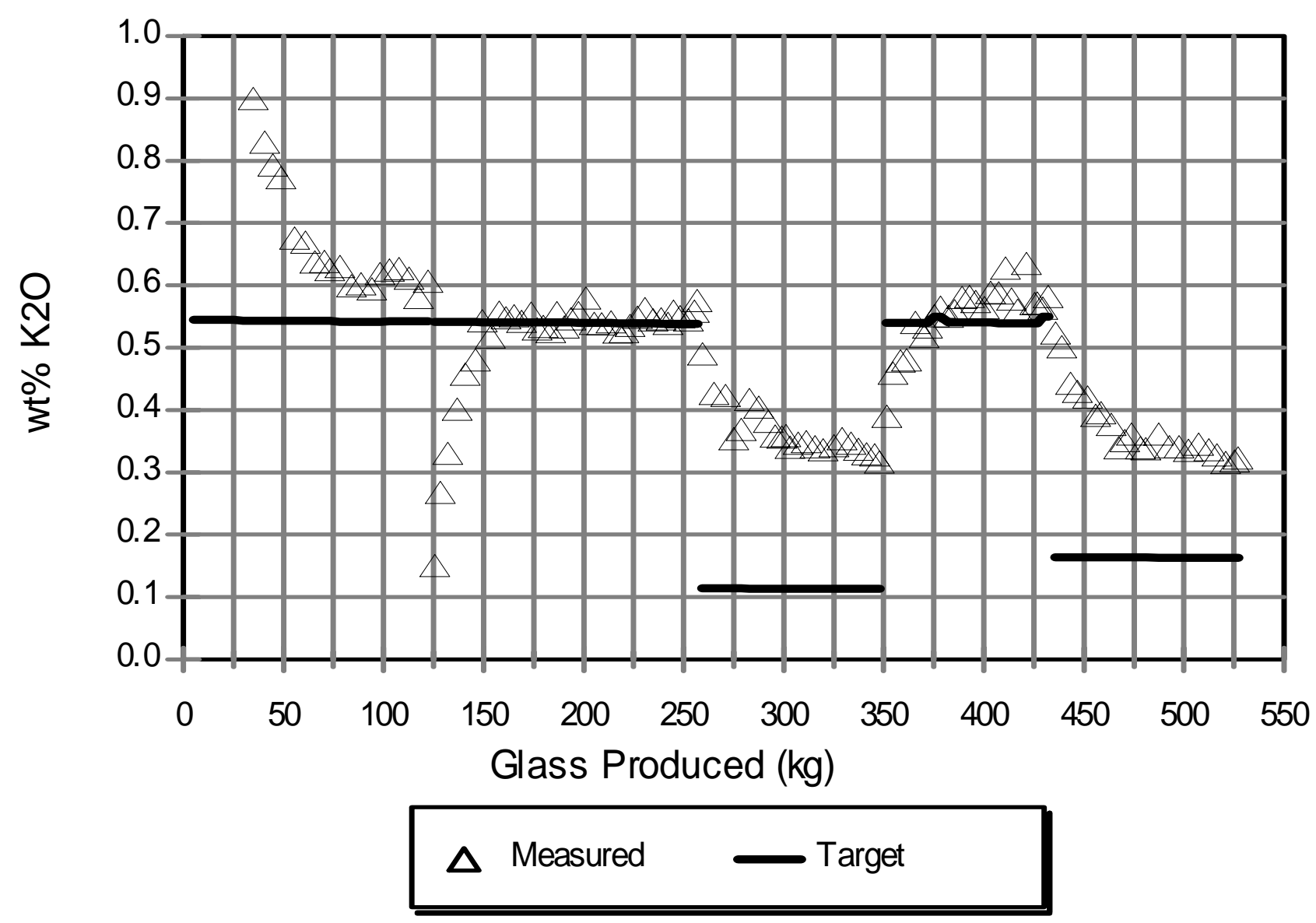

Figure 4.12. XRF analysis of potassium in DM10 product glasses. 


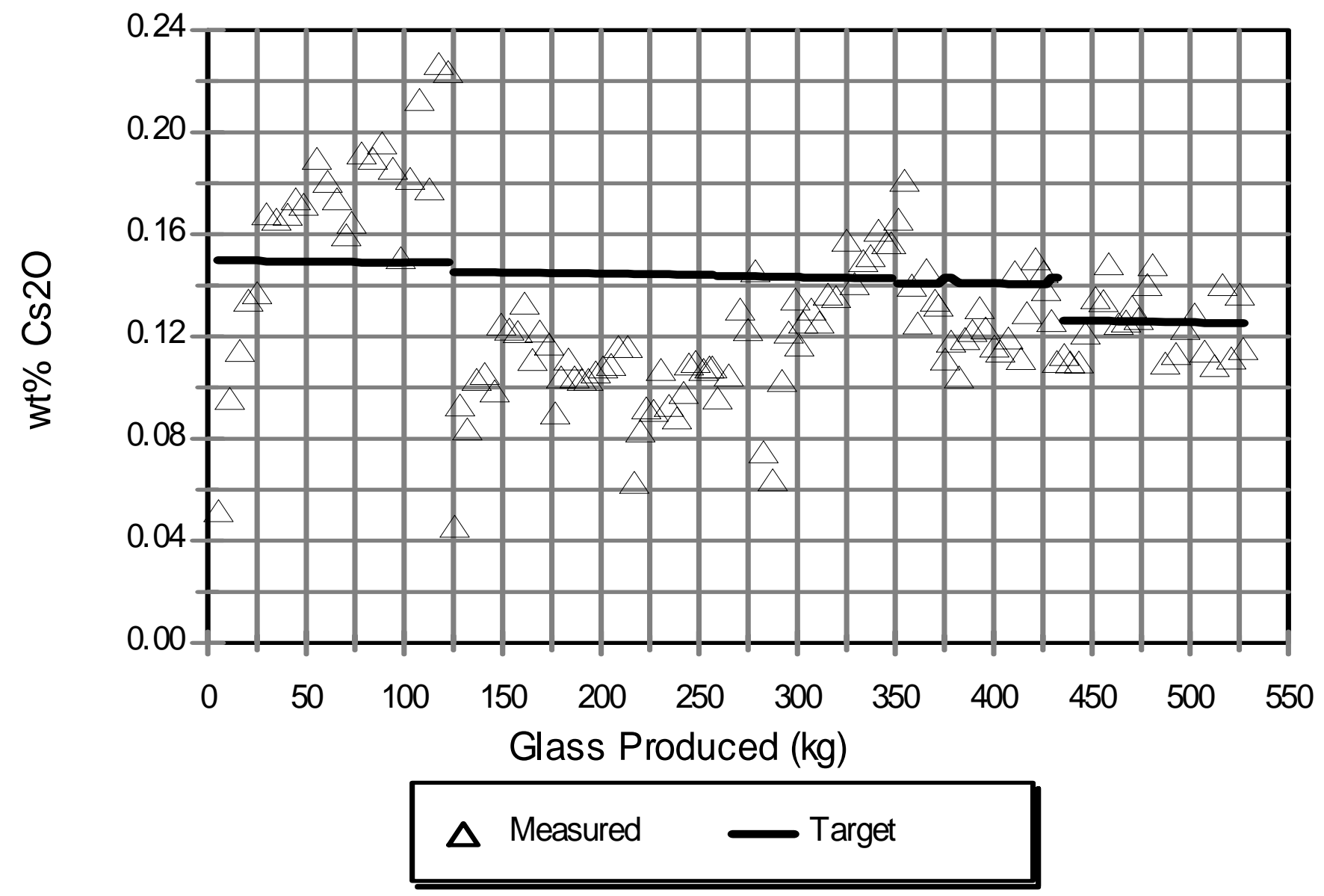

Figure 4.13. XRF analysis of cesium in DM10 product glasses. 


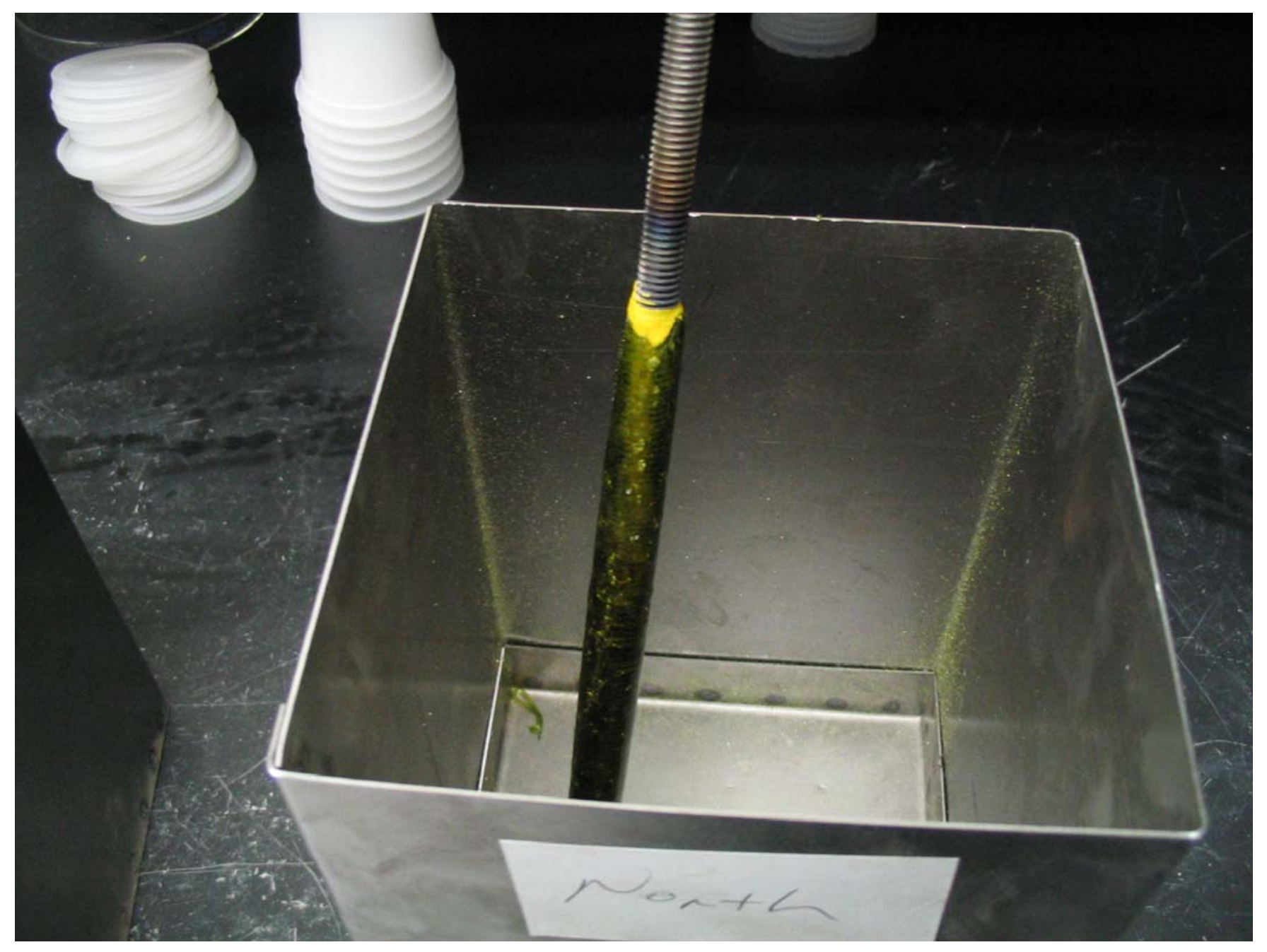

Figure 4.14. Secondary sulfur phases on dip sample Q10-D-148C from the end of Test 1D. 


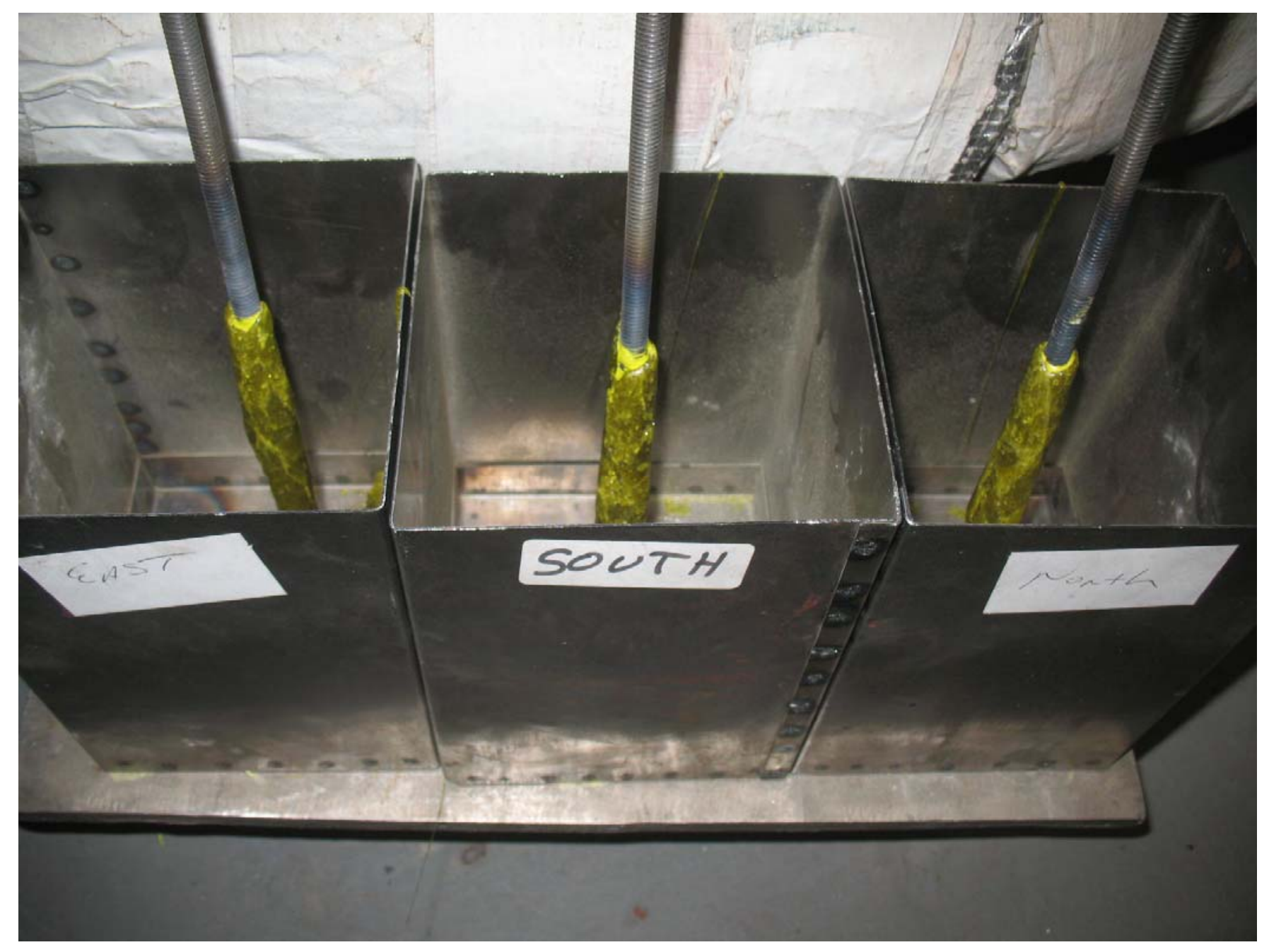

Figure 4.15. Secondary sulfur phases on dip samples S10-D-110A, B, and C from the end of Test 4D. 


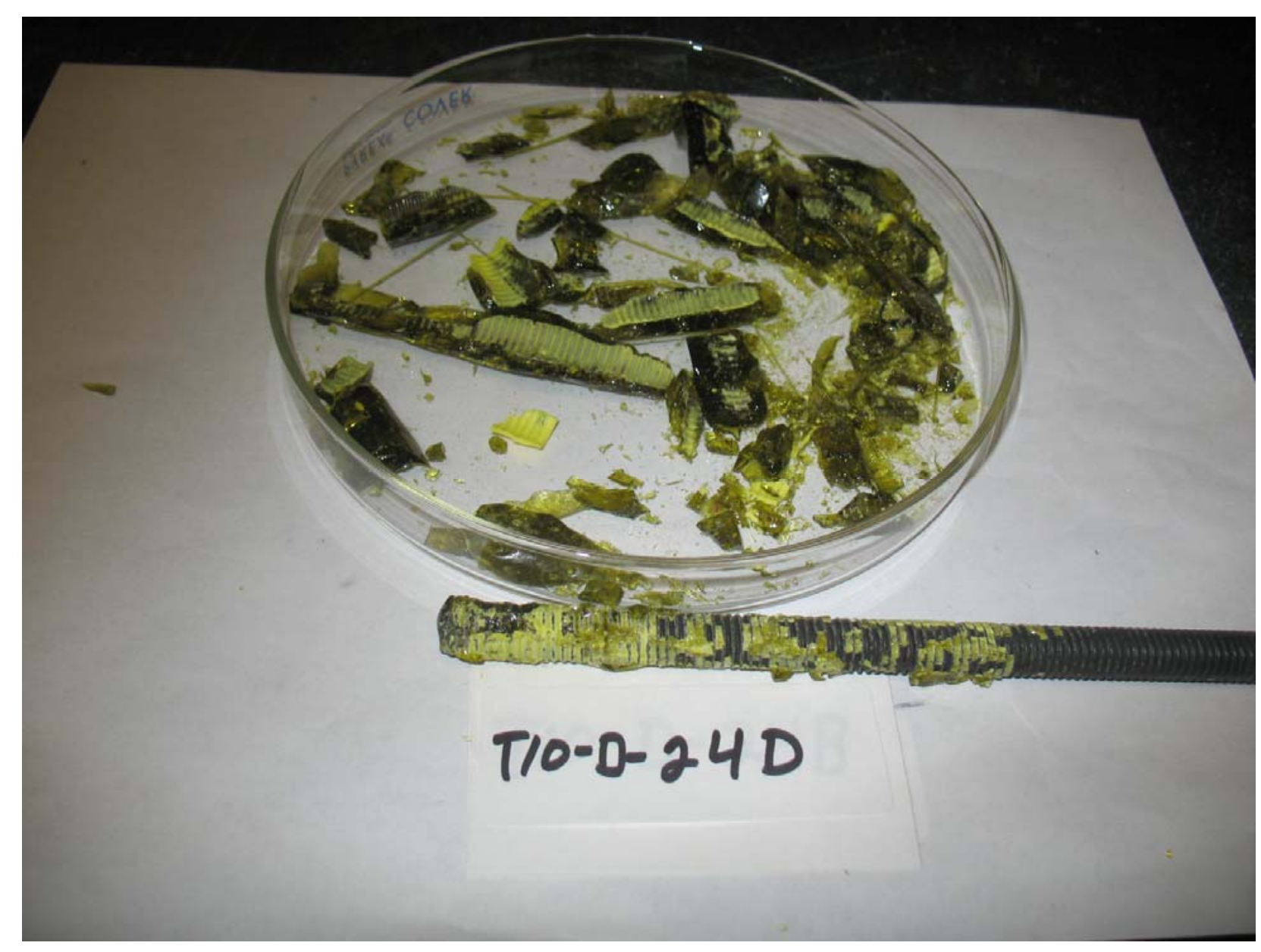

Figure 4.16. Secondary sulfur phases on dip sample T10-D-24D from the end of Test 5D. 
The Catholic University of America Vitreous State Laboratory
Enhanced LAW Glass Formulation Testing Final Report, VSL-07R1130-1, Rev. 0

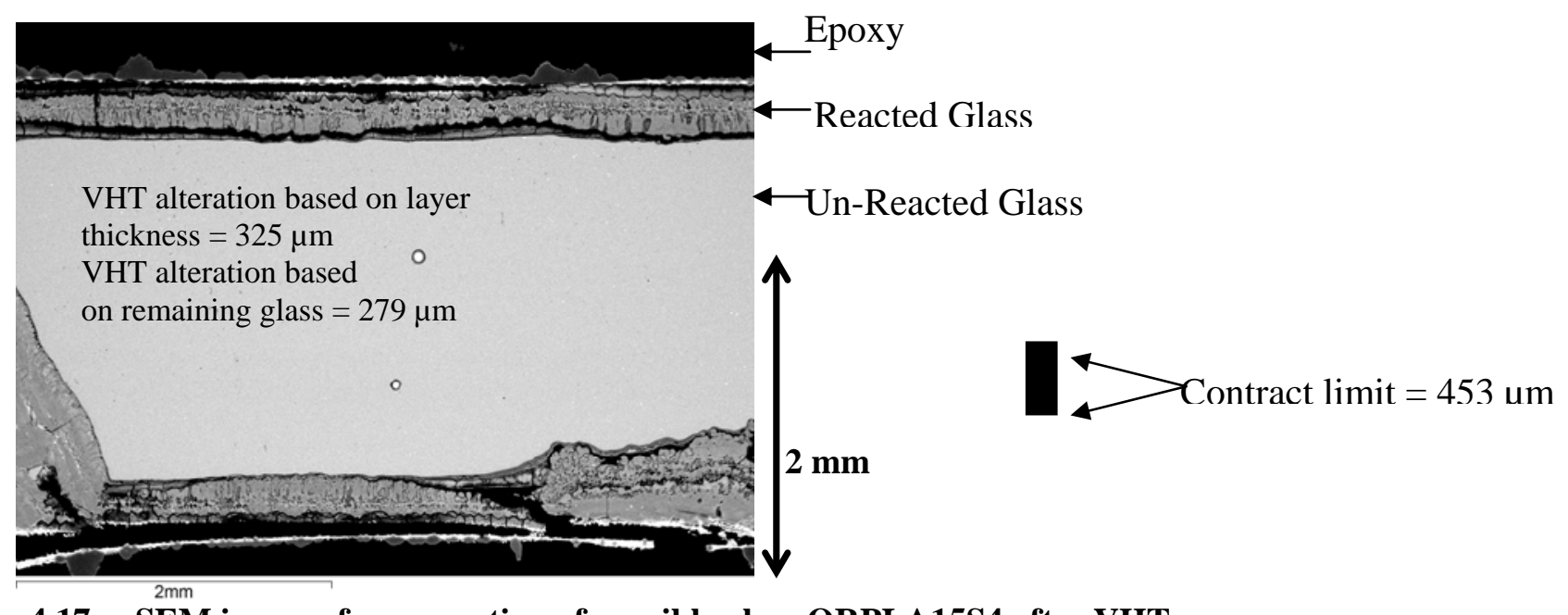

4.17 a. SEM image of cross section of crucible glass ORPLA15S4 after VHT

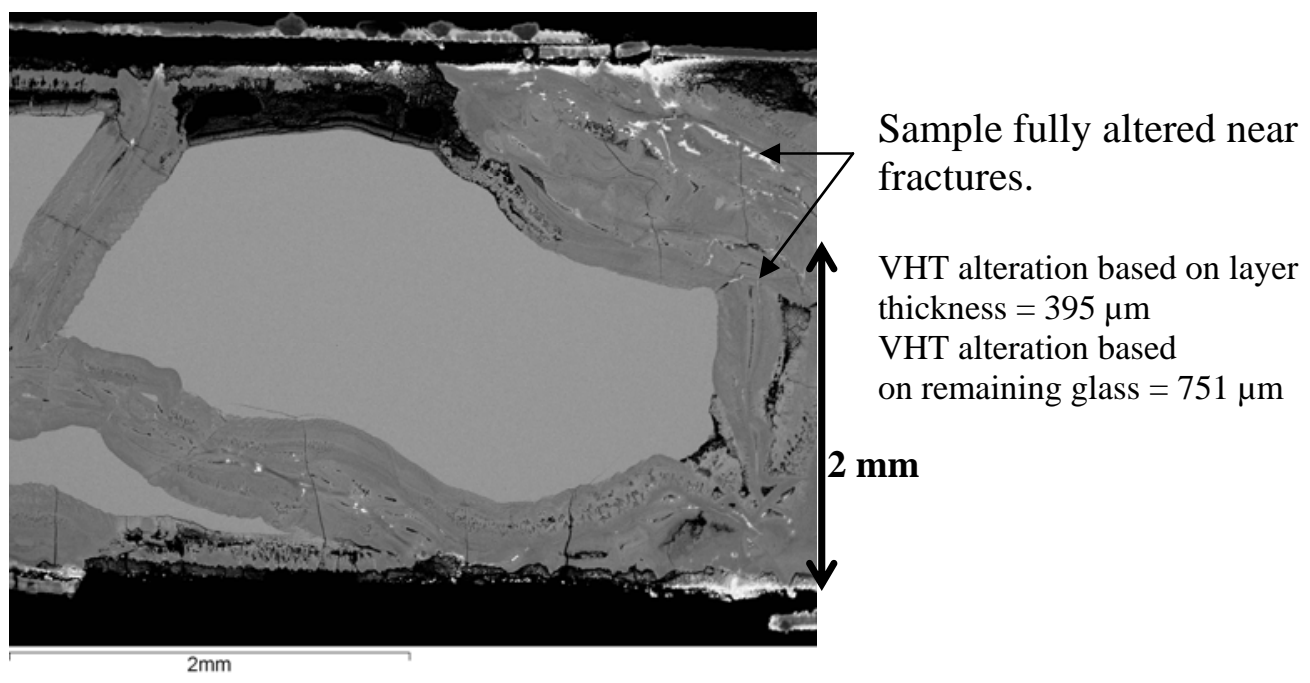

4.17 b. SEM image of cross section of DM10 melter glass R10-G-155A-remelt after VHT

Figure 4.17. Comparison of VHT coupons for glass formulation ORPLA15. 
The Catholic University of America Vitreous State Laboratory
Enhanced LAW Glass Formulation Testing

Final Report, VSL-07R1130-1, Rev. 0

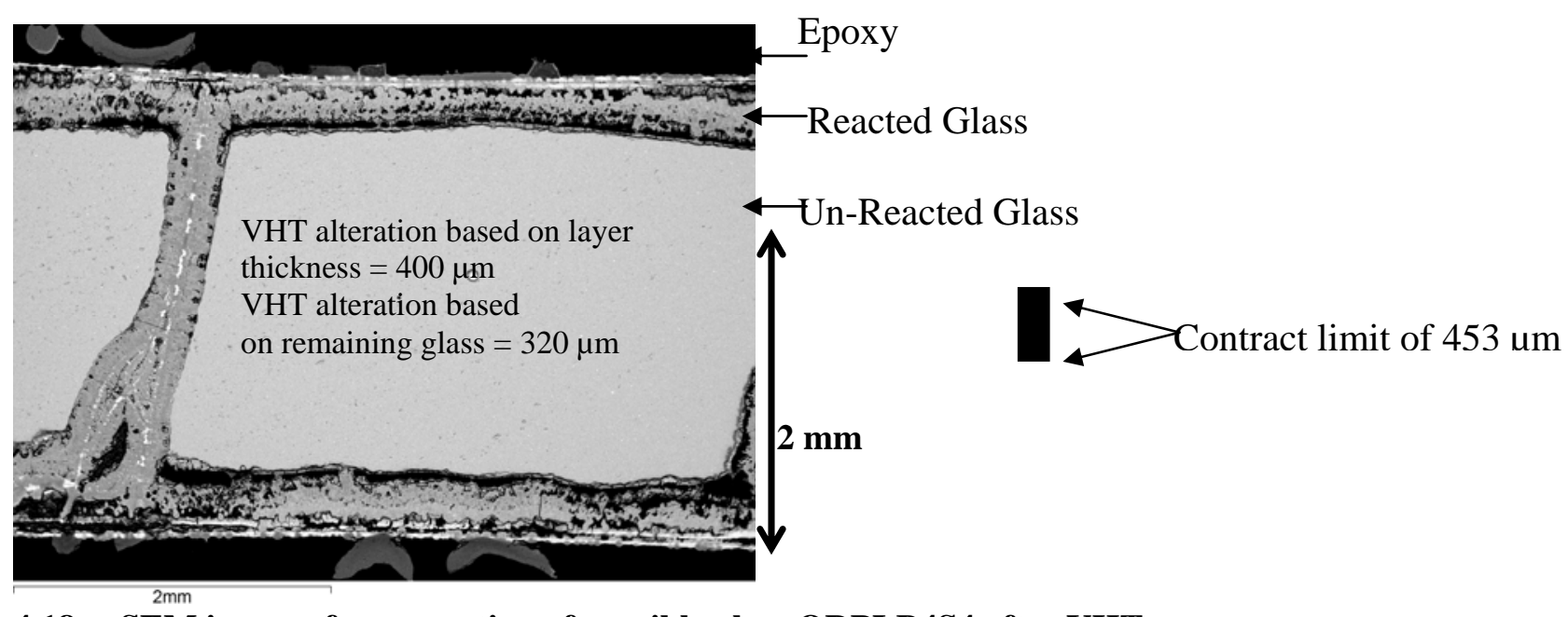

4.18 a. SEM image of cross section of crucible glass ORPLB4S4 after VHT

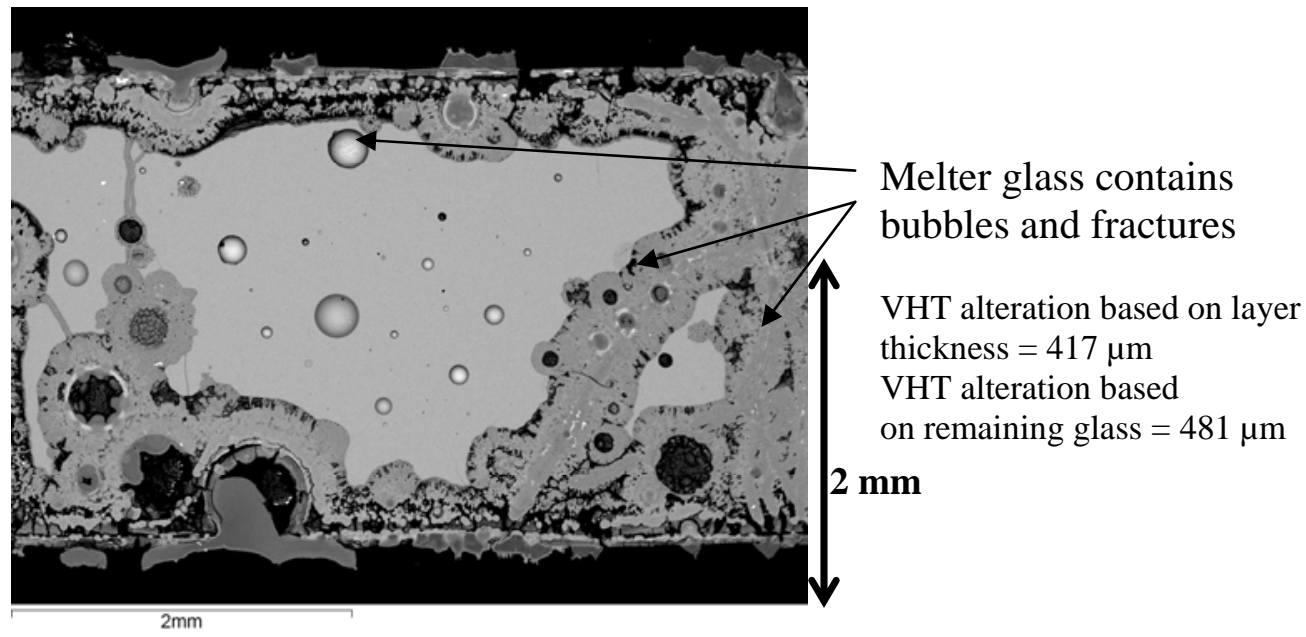

4.18 b. SEM image of cross section of DM10 melter glass S10-G-45A after VHT

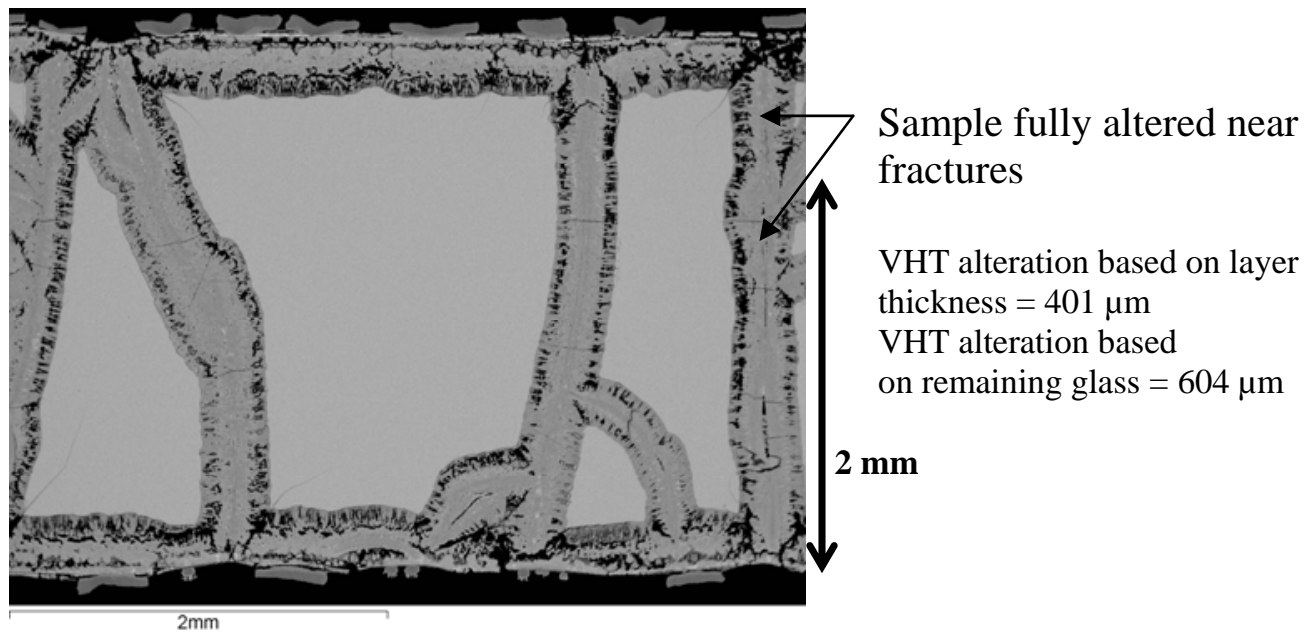

4.18 c. SEM image of cross section of DM10 melter glass S10-G-45A-remelt after VHT Figure 4.18. Comparison of VHT coupons for glass formulation ORPLB4. 
The Catholic University of America Vitreous State Laboratory
Enhanced LAW Glass Formulation Testing

Final Report, VSL-07R1130-1, Rev. 0

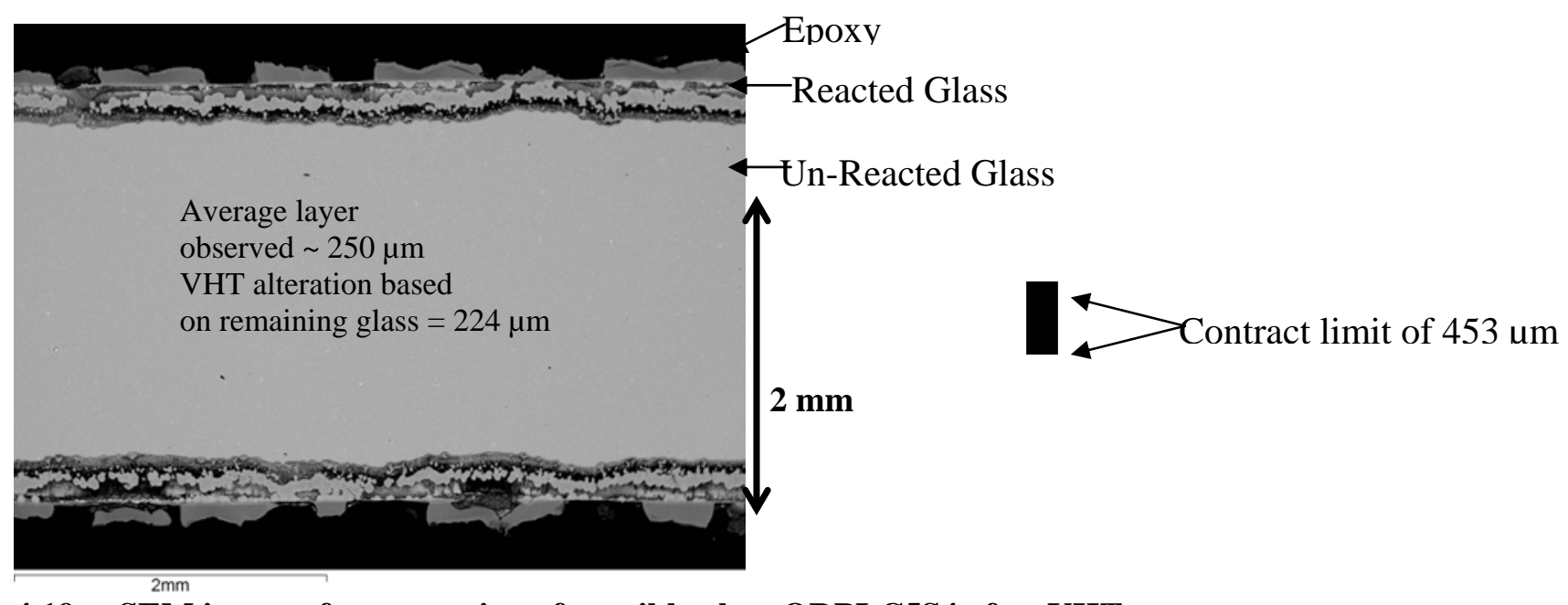

4.19 a. SEM image of cross section of crucible glass ORPLC5S4 after VHT

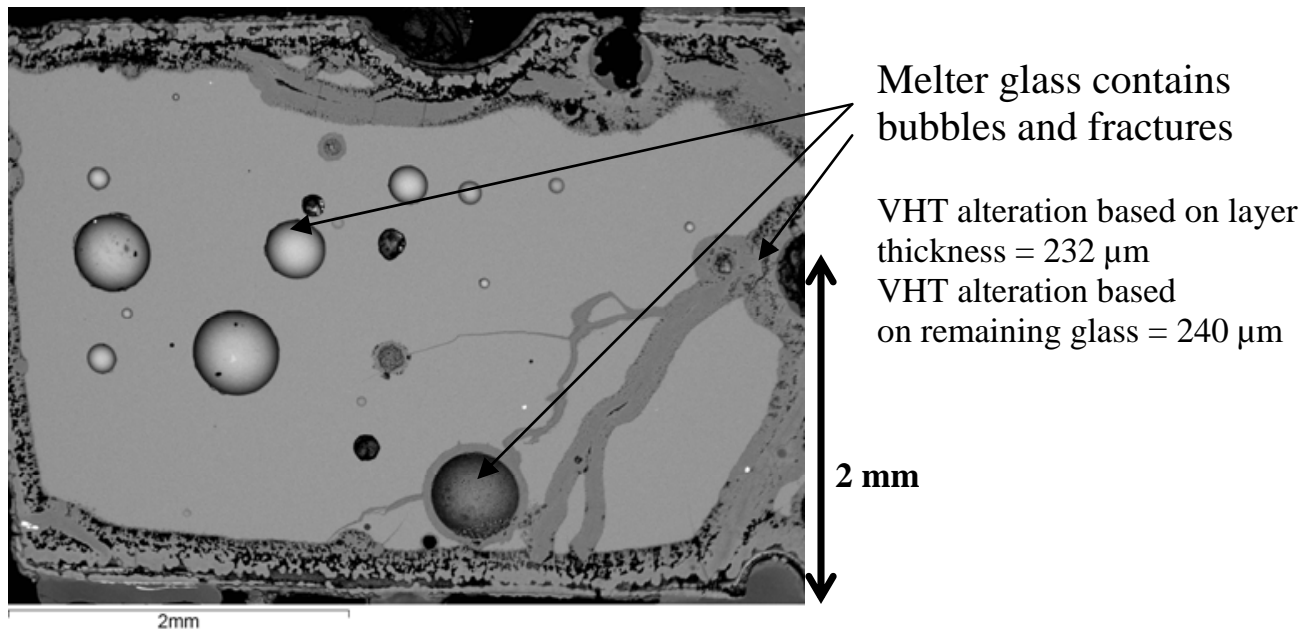

4.19 b. SEM image of cross section of DM10 melter glass S10-G-110B after VHT

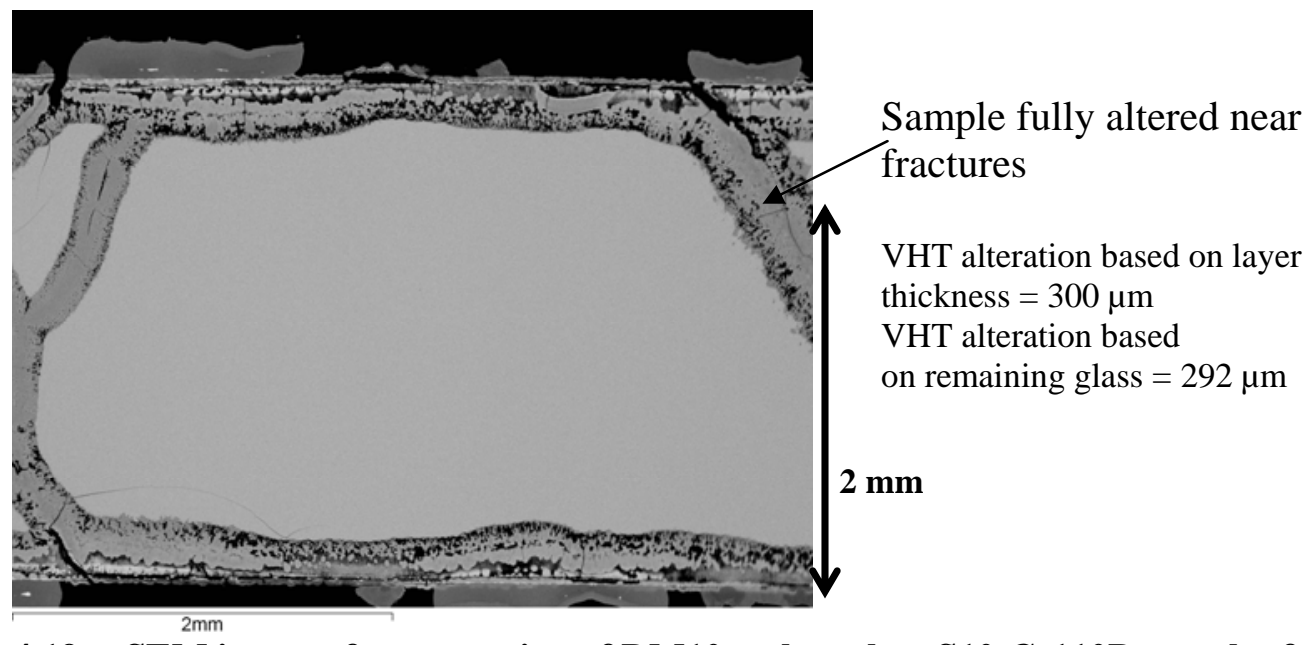

4.19 c. SEM image of cross section of DM10 melter glass S10-G-110B-remelt after VHT Figure 4.19. Comparison of VHT coupons for glass formulation ORPLC5. 


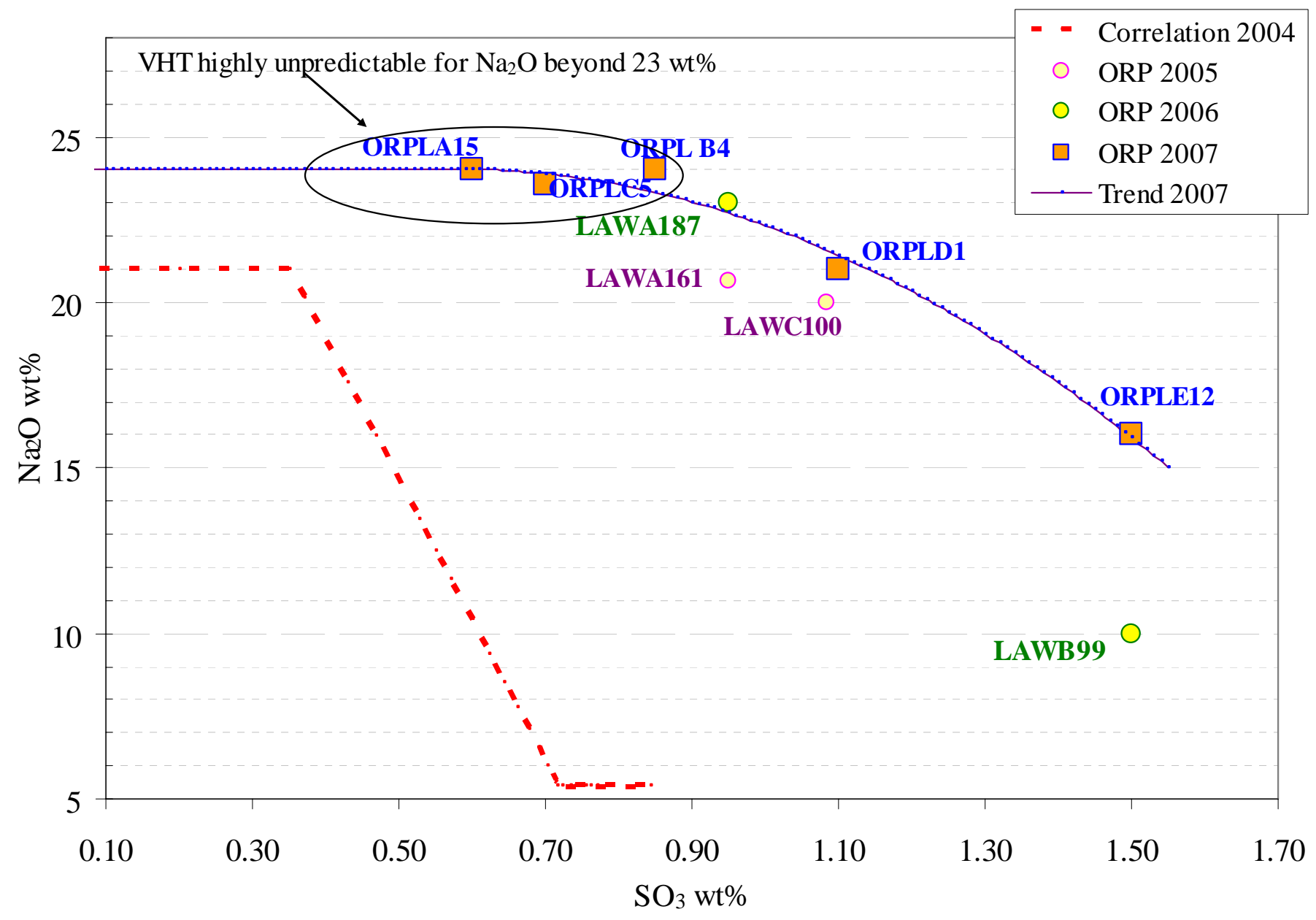

Figure 5.1. Overview of $\mathrm{Na}_{2} \mathrm{O}$ and $\mathrm{SO}_{3}$ loadings for WTP and ORP glasses. 